\title{
Evaluation of Thyroid Radioactivity Measurement Data from Hanford Workers, 1944-1946
}

\section{T. A. Ikenberry}

May 1991
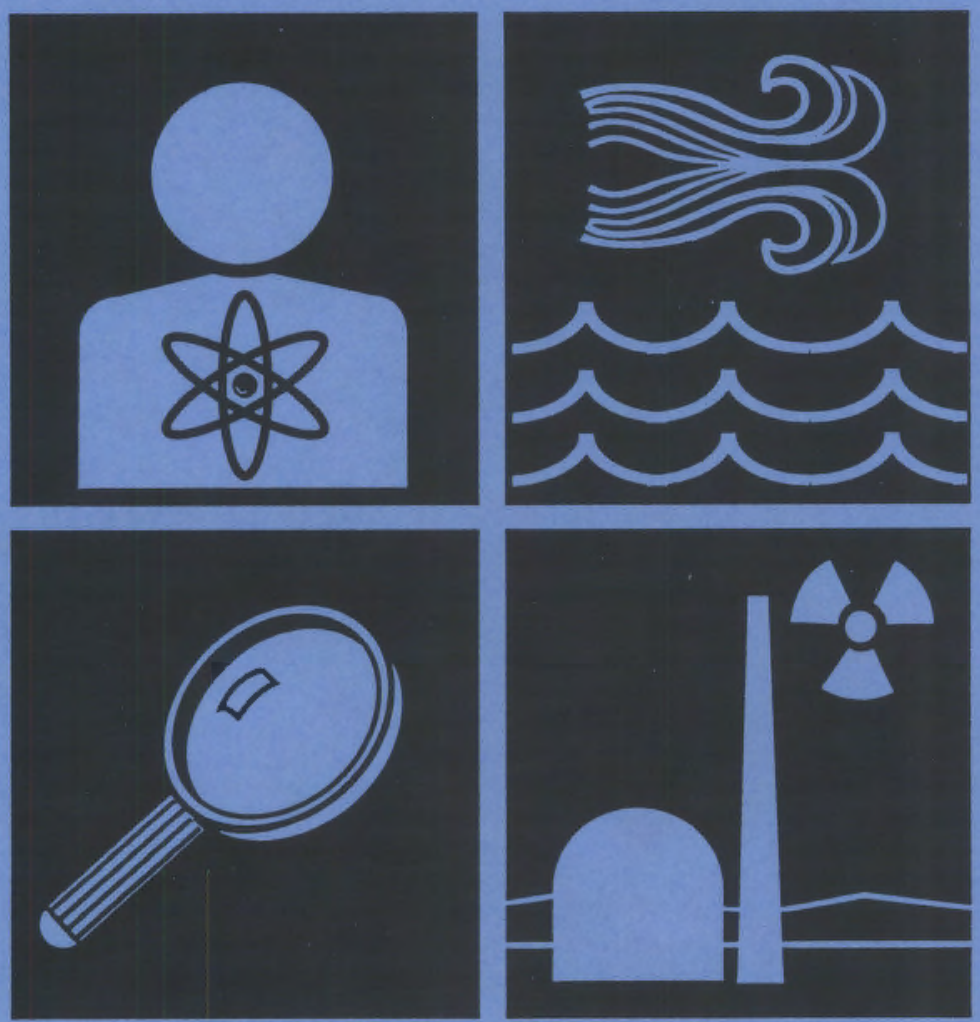

Prepared for the Technical Steering Panel

\% Baftelle 


\section{DISCLAIMER}

This report was prepared under the direction of the HANFORD ENVIRONMENTAL DOSE RECONSTRUCTION PROJECT Technical Steering Panel by Battelle Memorial Institute's Pacific Northwest Laboratories operating the Pacific Northwest Laboratory for the U.S. Department of Energy (DOE). While funding for the work was provided by DOE, the work is not under DOE direction or control. The views and opinions of the authors expressed in this document do not necessarily reflect those of the United States Government or any agency thereof. Reference herein to any specific commercial product, process or service by trade name, trademark, manufacturer or otherwise does not necessarily constitute or imply its endorsement, recommendation or favoring by the U.S. Government or any agency thereof, nor by Battelle Memorial Institute.

\footnotetext{
Printed in the United States of America

Available to DOE and DOE contractors from the

Office of Scientific and Technical Information, P.O. Box 62, Oak Ridge, TN 37831; prices available from (615) 576-8401. FTS 626-8401.

Available to the public from the National Technical information Service, U.S. Department of Commerce, 5285 Port Royal Rd., Springfieid, VA 22161.
} 


\section{EVALUATION OF THYROID RADIOACTIVITY \\ MEASUREMENT DATA FROM \\ HANFORD WORKERS, 1944-1946}

Hanford Environmenta] Dose Reconstruction Project

T. A. Ikenberry

May 1991

Prepared for

the Technical Steering Panel

Pacific Northwest Laboratory

Richland, Washington 99352 
EVALUATION OF THYROID RADIOACTIVITY MEASUREMENT DATA FROM

HANFORD WORKERS, 1944-1946

May 1991

This document has been reviewed and approved for by the Technical Steering Panel.

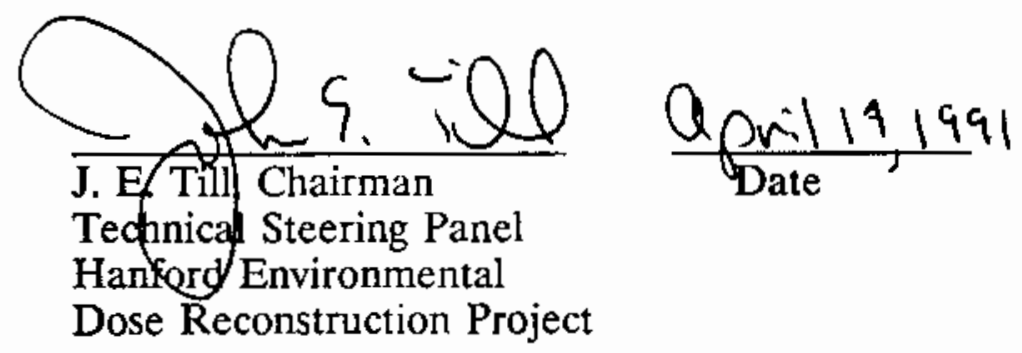




\section{FOREWORD}

Appendix $B$ is a record of TSP comments and Battelle's responses to those comments; the TSP has reviewed and approved Battelle's responses. The comment numbers appear in this document in the left margin next to the paragraphs in which the corresponding comments are addressed. Any text that has been changed is shown in italics. In addition to changes to address TSP comments, some text has been changed for correction of errors and for further clarification. 



\section{PREFACE}

This report describes the preliminary results of an evaluation conducted in support of the Hanford Environmental Dose Reconstruction (HEDR) Project. The primary objective of the HEDR Project is to estimate the radiation doses that populations could have received from nuclear operations at the Hanford Site since 1944. A secondary objective is to make information that HEDR staff members used to estimate radiation doses available to the public.

The objectives of this report were to make available thyroid measurement data from Hanford workers for the years 1944 through 1946, and to investigate the suitability of those data for use in the HEDR dose estimation process. An important part of this investigation was to provide a description of the uncertainty associated with the data. Lack of documentation on thyroid measurements from this period required that assumptions be made to perform data evaluations. These assumptions introduce uncertainty into the evaluations that could be significant. It is important to recognize the nature of these assumptions, the inherent uncertainty, and the propagation of this uncertainty through data evaluations to any conclusions that can be made by using the data.

Because the current objective is to make the historic thyroid measurement data publicly available, future work may be needed to quantitatively determine the overall measurement and calculational uncertainty, and therefore to determine if these data are sufficiently reliable to contribute to the HEDR dose estimation process. If questions on measurement uncertainty can be satisfactorily resolved, the potential for these Hanford worker data to provide thyroid dose information or act as a bounding case for general population thyroid doses may be addressed in a subsequent report. 



\section{SUMMARY}

Thousands of thyroid radioactivity measurements were made on Hanford workers employed in nuclear fuel reprocessing facilities during the years 1944 through 1946. These measurements were used at that time as a qualitative measure of radioactive iodine in worker thyroid glands. Called "thyroid checks," the measurements were performed in the general plant environment using portable radiation detection instruments. Results of the thyroid check measurements were compared to a screening level for tolerable thyroid exposure from iodine-131 to assure that workers did not receive excessive iodine-131 exposures.

Results of 7933 thyroid check measurements made on nearly 1600 individual workers were collected from personnel survey summary records and evaluated. Measurement dates ranged from October 1944 to September 1946, with more than $99 \%$ of the results from June 1945 through August 1946. These measurement results represent more than $96 \%$ of the 8211 thyroid checks known to have been made during this period.

Observed measurement count rate results and estimated iodine-131 thyroid burdens were low. The highest observed thyroid check result was 49 net counts per minute (cpm). More than $36 \%$ of all results were zero, and $98 \%$ of the results were less than 20 net $\mathrm{cpm}$. Using a historically determined calibration factor for iodine-131 in the thyroid, the highest count rate result was estimated to represent a point-in-time thyroid burden of $130 \mathrm{nCi}$. More than $98 \%$ of the point-in-time thyroid burdens estimated from count rate results were less than $50 \mathrm{nCi}$ of iodine-131. The established screening level during most of this time period was $750 \mathrm{cpm}$, which corresponded to an iodine-131 thyroid burden of $2 \mu \mathrm{Ci}$. This $2-\mu \mathrm{Ci}$ thyroid burden was based on a stated long-term "thyroid radiation tolerance" of "l $\mathrm{r} /$ day, "which is approximately equal to $1.2 \mathrm{rad} / \mathrm{day}$.

The thyroid radioactivity measurement data are subject to uncertainty that may limit their usefulness to the HEDR dose estimation process. Uncertainties associated with the measurement process must be better defined for available data and related information to be used for drawing definitive 
conclusions about thyroid doses or acting as a bounding case for general population doses. Sources of uncertainty include

- the qualitative nature of the thyroid checks; the checks were intended only as part of a screening program for worker exposure to the tolerance amount of radioactive iodine, not as quantitative determinations of worker thyroid dose

- the small amount of detailed information available on thyroid check measurement procedures, data recording or interpretation, or worker selection and sampling

- infrequent sampling on an individual basis for a short-lived radionuclide like iodine-13I at inconsistent intervals

- the fact that more than $98 \%$ of the results were within a factor of two of the normal instrument background levels, resulting in a rather high statistical uncertainty

- use of portable or semiportable detection instrumentation

- lack of information on the exposure pathway of the radioactive jodine

- lack of differentiation between relative contribution of occupational or environmental sources of radioactive jodine

- only inferential evidence that iodine-131 was the radionuclide being measured; apparent sources of radiation other than iodine-131 were discovered in the data. 


\section{CONTENTS}

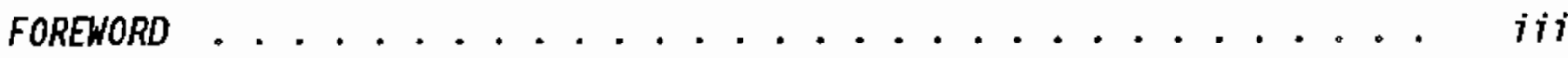

PREFACE ......................

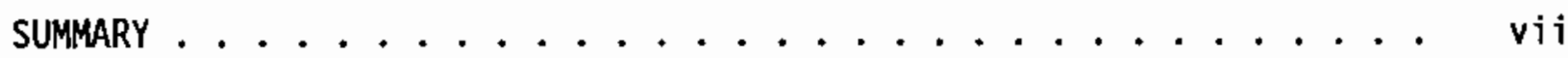

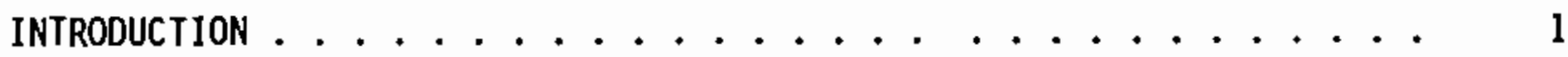

THYROID RADIOACTIVITY MEASUREMENTS . . . . . . . . . . . . 3

THYROID CHECKS .................... 3

WORKERS RECEIVING THYROID CHECKS . . . . . . . . . . 4

THYROID CHECK DETECTION INSTRUMENTS ............ 5

BEGINNING OF ROUTINE THYROID CHECK PROGRAM . . . . . . . 7

THYROID RADIATION TOLERANCE LEVELS ............. 8

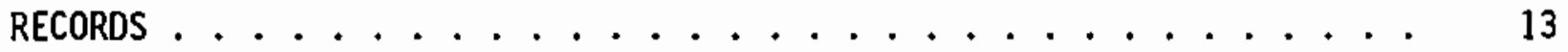

SOURCES OF MEASUREMENT UNCERTAINTY . . . . . . . . . . . 15

RECORDS AND MEASUREMENT DATA ..................... 15

PROCEDURES. .............................. 16

USE OF PORTABLE INSTRUMENTS . . . . . . . . . . . 17

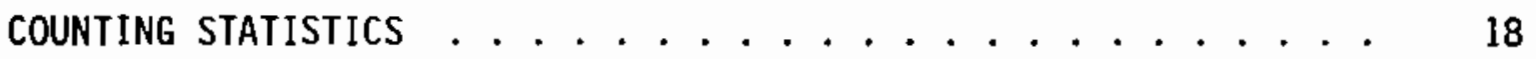

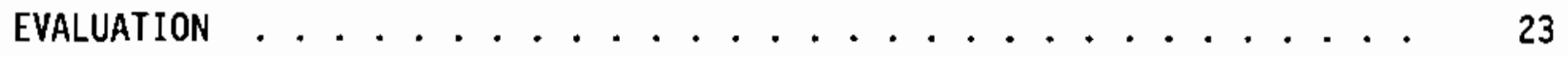

RESULTS AND DISCUSSION . . . . . . . . . . . . . . 25

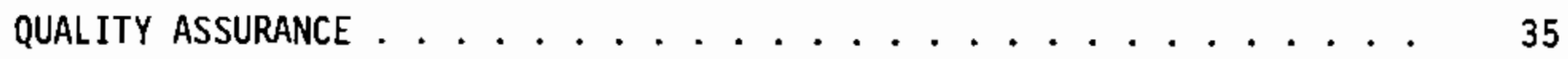

REFERENCES .......................... 37

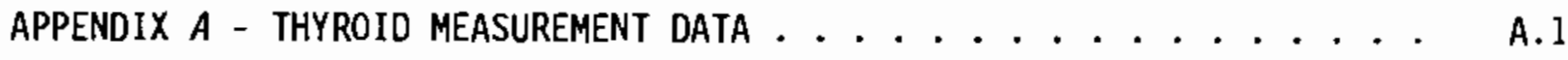

APPENDIX B - SUMMARY OF TSP COMMENTS AND BATTELLE RESPONSES . . . . . . B.1 


\section{FIGURES}

1 Relative Counting Error of Thyroid Measurements . . . . . . . . 21

A.l Typical Personnel Meters Sumnary Record Sheet . . . . . . . A.2

\section{TABLES}

1 Thyroid Checks Performed in the Separations Plants, 1945-1946 . . . . . . . . . . . . . . . . .

2 Early Evolution of the Thyroid Radiation Tolerance Level for Iodine-131 at the Hanford Engineering Works . . . . . . . . . 10

3 Number of Thyroid Check Measurements Performed Per Month . . . . . 26

4 Distribution of Thyroid Check Observed Net Count Rate Results . . 28

5 Distribution of Estimated Iodine-131 Thyroid Burdens . . . . . . 31

A.1 Listing of Thyroid Measurement Data from Hanford

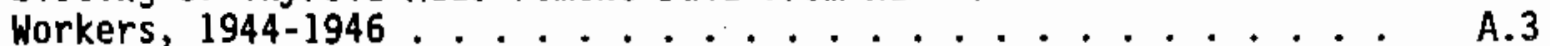




\section{INTRODUCTION}

In recent years concern has been mounting about possible health effects to the public from more than 40 years of operations at the Hanford Site. These operations have resulted in the release of radioactive airborne emissions and liquid effluents to the environment. In 1986, following a review of epidemiological and environmental data relevant to Hanford operations, the Hanford Health Effects Review Panel recommended that a study be conducted to reconstruct potential radiation doses to the general public.

The Hanford Environmental Dose Reconstruction (HEDR) Project was begun to develop estimates of the radiation doses that populations could have received from Hanford operations, along with descriptions of the uncertainties inherent in such estimates. Of particular interest is the development of radiation doses for the period before 1957, when the first historical radiation dose estimates were reported in annual environmental monitoring reports. Battelle staff at the Pacific Northwest Laboratory conduct the project under the direction of an independent Technical Steering Panel.

The period of study for the HEDR Project begins in September 1944, when the first reactor, B Reactor, went into operation. The nuclear industry was in its early infancy, and the Hanford facilities were the first of their kind in the world. Radiation in large doses was known to be harmful to humans, and the large quantities of radioactive material being produced and processed caused concern about radiation health effects on workers. Actions were taken to control and monitor worker radiation exposure; one of these exposure monitoring actions was a periodic check for the presence of radioactive iodine in the thyroid.

lodine-131 was one of the radionuclides first known to be a potentially significant hazard to workers involved with Hanford fuel reprocessing operations. A beta-gamma radiation emitter, iodine-131 concentrates in the thyroid $g l$ and, which is the critical organ for evaluating radiation dose from radioiodines. Iodine-131 is created in large quantities in nuclear reactor 
fuel and is intensely radioactive because of its relatively short half-life of 8 days. During 1944 through 1946, iodine-131 was present in fuel sent to the reprocessing plants.

During fuel reprocessing, transuranic radionuclides were recovered from the irradiated reactor fuel. Other radionuclides were generally treated as waste material. Reprocessing released the radioactive iodine from the fuel, mainly in a volatile form that was transportable. Fuel reprocessing plant workers could be exposed from leaks in process lines or vessels, or from stack emissions containing iodine-131. These emissions could be present in the processing plant environment, as well as at locations off the Hanford Site as a result of environmental dispersion. Fuel reprocessing plant workers could be exposed to iodine-131, therefore, in two distinctly different ways: I) in the workplace, as part of their norma 1 jobs; or 2) from the environment, as part of the general public during those hours when they were not working at Hanford.

The thyroid measurements made on these Hanford workers may therefore provide information on iodine-131 in the thyroid gland resulting from environmental as well as occupational exposures to iodine-131. It may be possible to use measurements made for occupational purposes to estimate worker environmental exposures to iodine-131, and to further extrapolate to thyroid exposures to the general public near the Hanford Site.

This report presents the available thyroid measurement data from Hanford workers for the years 1944 through 1946. It also investigates the suitability of that data for use in the HEDR dose estimation process, and provides a description of the uncertainties associated with the data. Additional1y, estimates of point-in-time worker thyroid burdens of iodine-131, derived from the measurement data, are presented. 


\section{IHYRO1D RADIOACTIVITY MEASUREMENTS}

Thyroid radioactivity measurements on workers at the Hanford Engineering Works were closely tied to the beginning of fuel reprocessing operations. The T-PTant separations facility began reprocessing operations in December 1944, and a second plant, B-Plant, began operation in April 1945 (Stainken 1948). These two plants accounted for essentially all of the radioactive iodine emissions at Hanford during the 1944 through 1946 time period.

\section{IHYRO1D CHECKS}

The only thyroid monitoring done during this period was called a thyroid check. Thyroid checks were a quick, simple, non-invasive technique for qualitatively measuring the amount of radioactive iodine in the thyroid of a worker. They were used as a screening technique, with results compared to a . thyroid radiation tolerance level to assure that a thyroid overexposure did not occur. Thyroid checks were apparently not considered to be part of an official bioassay program, and a historical review of personnel dosimetry programs at Hanford makes no mention of them (Wilson 1987).

The thyroid checking technique used a portable Geiger-Mueller (GM) detector to measure the gamma radiation being emitted from radioactive jodine in the thyroid $\mathrm{gland}$. The detector was placed lightly against a worker's neck near the thyroid, which is bi-lobed and located in front of and on either side of the trachea roughly halfway between the larynx and the clavicle. Performed by a Health Instruments Inspector (modern day equivalent to a health physics technician), two readings were taken, one each on the right and left lobes of the thyroid gland. Results of both right and left measurements were then recorded, apparently as net counts per minute above background.

The first documentation of thyroid checks being performed is found on Personnel Meters Summary record sheets (Figure A.l, appendix), which are the source of measurement data evaluated as part of this study. These records indicate that the first thyroid checks were performed in late September or October 1944, well before the first reprocessing plant became operational in December 1944. 1t is possible that these early checks were unique, nonroutine 
measurements taken, for example, on workers in experimental or developmenta] laboratories. Early thyroid check data may also be a result of transcription errors on the Personnel Meters Summary sheets, as numerous date errors and inconsistencies have been identified. In any event, these early checks (before May 1945) are few and represent a small fraction of the total records examined. Formal Hanford Works reports do not indicate thyroid checks being performed until late May 1945 with the implementation of a routine thyroid check program.

As part of a routine program, thyroid checks were performed "...as a part of the periodic medical examination done in the area." (Cantril and Healy 1945). The scheduled frequency of the examination is not known, but it appears that the counts would have been taken not in the radiation work areas but in the general $\mathrm{plant}$ area, perhaps in a designated medical or first aid office. This is important because the GM detectors used detected any incident gamma radiation; they were not specific to the gamma radiation being emitted by iodine-131. Therefore, any other radiation present, such as high background radiation, external skin or clothing contamination, or internal contamination by radionuclides other than jodine-131 could contribute to the reading assumed to be entirely iodine-131. By taking the thyroid checks in a plant area isolated from process operations, contribution from these other sources of radiation could have been more easily avoided and detected if they existed.

\section{WORKERS RECEIVING THYROID CHECKS}

Thyroid check measurements were made on workers who had the highest potential exposure to radioactive iodine. Because the fuel reprocessing activities in the 200 Areas were known to be the greatest source of radioactive iodine, thyroid monitoring efforts were concentrated on workers in these areas. Summaries of the monthly thyroid checks (Operating History 1946) indicate $T$ and $U$ Plants in the 200 West Area, and B Plant in 200 East Area as the only locations where thyroid checks were taken. The Personnel Meters Summary record sheets very rarely indicate an individual who worked elsewhere; for example, in the 300 Area. 
Thyroid check procedures from 1953 (Radiation Monitoring Sub-Section 1953) indicate that the people receiving thyroid checks were mostly those in the reprocessing facilities--sample collectors and canyon crane operators. They were checked weekly. Also checked were patrolmen, who received thyroid checks every 4 months. In the 1944 through 1946 time period, however, it appears that the scope of the thyroid checks was broader than in 1953. Evaluation of the summary sheets revealed that nearly 1600 individuals received thyroid checks, a larger number than would be expected for canyon workers and patrolmen alone. Very likely all of the individuals working in $T, U$, and $B$ plants received thyroid checks during this time period.

\section{THYROID CHECK DETECTION INSTRUMENTS}

The earliest mention of the instruments used to make the thyroid checks was on June 5, 1945 (Parker and Gamertsfelder 1945). The use of "special thyroid counters" was noted, implying that something other than the normal survey detection instruments were used. Similarly, "A precise calibration of thyroid counters..." is noted in the June 30, 1945, monthly report (Parker 1945a). Not until October 1945 is the thyroid counter identified as "...a sma11 brass Geiger-Müeller counter..." (Cantril and Healy 1945). Brasswalled counters are again mentioned in December 1945, and a somewhat more detailed description of the brass-walled counter is given in the July 1946 report (Healy 1946) on calibration of detector readings to thyroid iodine-131 activity. It is assumed that all these references describe the same brasswalled GM detectors.

From descriptions in the referenced reports and anecdotal descriptions of the instruments, these thyroid detectors were simply a portable GM detector with a brass-walled probe. Healy (1946) described the detector probe as being $4.5 \mathrm{in.}(11.4 \mathrm{~cm})$ long and $0.75 \mathrm{in} .(2 \mathrm{~cm})$ in diameter, with a wall thickness of $1 / 32$ in. $(0.08 \mathrm{~cm})$. His calibration studies indicated 375 counts per minute $(\mathrm{cpm})$ for $1 \mu \mathrm{Ci}$ of iodine-131 in the thyroid, an efficiency of less than $0.02 \%$.

Using a thyroid phantom, Healy checked the effect of counter and thyroid position on instrument readings. Measurements were made on the left lobe, 
right lobe, and center of the thyroid. None were significantly different from one another, so an average value was used. Moving the detector as far as $20 \mathrm{~mm}$ either below or above the isthmus of the thyroid resulted in a reading approximately $83 \%$ of the maximum reading, which was taken on the thyroid isthmus. A reading taken $30 \mathrm{~mm}$ above the isthmus was $72 \%$ of maximum.

ATso checked was the effect of thyroid depth on instrument readings. Healy assumed a thyroid depth of $4 \mathrm{~mm}$, which gave $750 \mathrm{cpm}$ per $2 \mu \mathrm{Ci}$ of iodine131 in the thyroid. Thyroid depth effects up to $16 \mathrm{~mm}$ were checked, with a 16- $\mathrm{mm}$ depth resulting in a reading approximately $50 \%$ of that at $4 \mathrm{~mm}$.

Only two reports (Cantril and Healy 1945; Parker 1945b) make any mention of the instrument background. Both these reports describe the normal background rate of this counter as being $20 \mathrm{cpm}$. It is possible that a normal background rate is mentioned so some measure of the detection limit can be made. In 0ctober 1945 the detectable level was "1/100th" of the tolerable amount of iodine-131 in the thyroid, while in December 1945 it was revised to "1/20th" of the tolerable amount.

All evaluations of thyroid check results done in this report assume that the particular brass-walled GM detectors were used for all measurements, although the instrument was not specifically identified until october 1945. Unfortunately, these counters apparently neither exist today nor apparently do any descriptions other than those referenced here. A detailed historical review of portable instruments used at Hanford since 1944 (Howell et al. 1989) does not make specific reference to the brass-walled GM detectors. It is possible that the brass-walled GM used was either a Victoreen GM or an Eltronics $\mathrm{GM}$, with a specially modified probe. These were portable instruments with count rate meters rather than scalers.

Anecdotal information, however, describes the brass-walled counters as a rather heavy instrument that was powered by regular $110 \mathrm{~V}$. It used a binary scaler, with a movable brass-walled probe connected by cord to the body of the instrument. Because these instruments were somewhat cumbersome, they were usually left in the Health Inspector office, and thyroid checks were conducted there. 
BEGINNING OF ROUTINE THYROID CHECK PROGRAM

A routine program of checking worker thyroids for the presence of radioactive iodine was not begun until late May or June 1945 (Parker and Gamertsfelder 1945). The impetus for implementing a routine program came from two separate events, occurring on May 27 and May 30, 1945. Changing meteorological conditions caused the plant emission plumes to downdraft from the stack and enter the facilities. The following description of the events is taken from the June 1, 1945, weekly report for the Health Instruments Section (Parker and Gamertsfelder 1945):

"Sudden wind changes brought active fumes to the ground within the plant areas on the day shifts on $5 / 27 / 45$ and $5 / 30 / 45$. The concentration of radioactive iodine was not accurately measured, but it was approximately 100 times the continuously tolerable value, and probably occurred with a dilution factor from the direct stack gas of between 100 and 200 .

The atmospheric activity rapidly dispersed, but wherever the fumes had been, a coating of active iodine was left. Ground contamination of $0.8 \mathrm{mrep} / \mathrm{hr}$ and $2.5 \mathrm{mrep} / \mathrm{hr}$ was caused in the respective incidents. The fumes were sucked into the buildings 221 and 222 and indoor contamination was widespread. In the Control Laboratory, 222-T, the background on the four-fold hand counter rose to 17 registers from the normal of 3 to 4 . The filters on all air conditioning systems functioned as iodine collectors, and became strongly active $(\approx 28 \mathrm{mrep} / \mathrm{hr})$. Dry filters as in Room 19, 222-T, were inefficient collectors and the indoor contamination in such areas was consequently higher.

In the B-Plant, the clothing of many employees became contaminated, but no garment was found to give a contact dosage-rate in excess of $1.5 \mathrm{mrep} / \mathrm{hr}$. This was almost the same as the plant permissible level of hand contamination (one-third of the tolerable value $4.17 \mathrm{mrep} / \mathrm{hr}=1.4 \mathrm{mrep} / \mathrm{hr}$ ). As the clothing was worn 16 hours a day against 24 hours for the hands, it was considered unnecessary to withdraw the personal clothing. Activity on the hands and face was readily removed by washing.

The most probable hazards from such depositions of radioactive iodine would be those of ingestion or inhalation, both of which send iodine to the thyroid. The tolerance dosage for such effects is known better than that for any other fission product, due to its prior use in therapy. The limiting dose gives a reading of about 2000 counts per minute on the special thyroid counters provided. To date no reading in excess of 20 counts per minute has been recorded, and this was probably partially due to contaminated 
clothing. Nevertheless, a regular program of thyroid checks has been developed [emphasis added]."

Routine thyroid checks began almost immediately, with 160 checks performed in June 1945 and nearly 800 performed in July 1945. Between 450 and 800 thyroid checks were performed month7y from Juiy 1945 through August 1946. Table 1 shows the summary of monthly thyroid checks performed during this time period.

\section{IHYROID RADIATION TOLERANCE LEVELS}

The June 1, 1945, weekly report that documented the beginning of the routine thyroid check program also indicated that Hanford personnel were aware of radioactive iodine in the emission plume and considered it to be the

TABLE 1. Thyroid Checks Performed in the Separations Plants, 1945-1946 (from Operating History 1946)

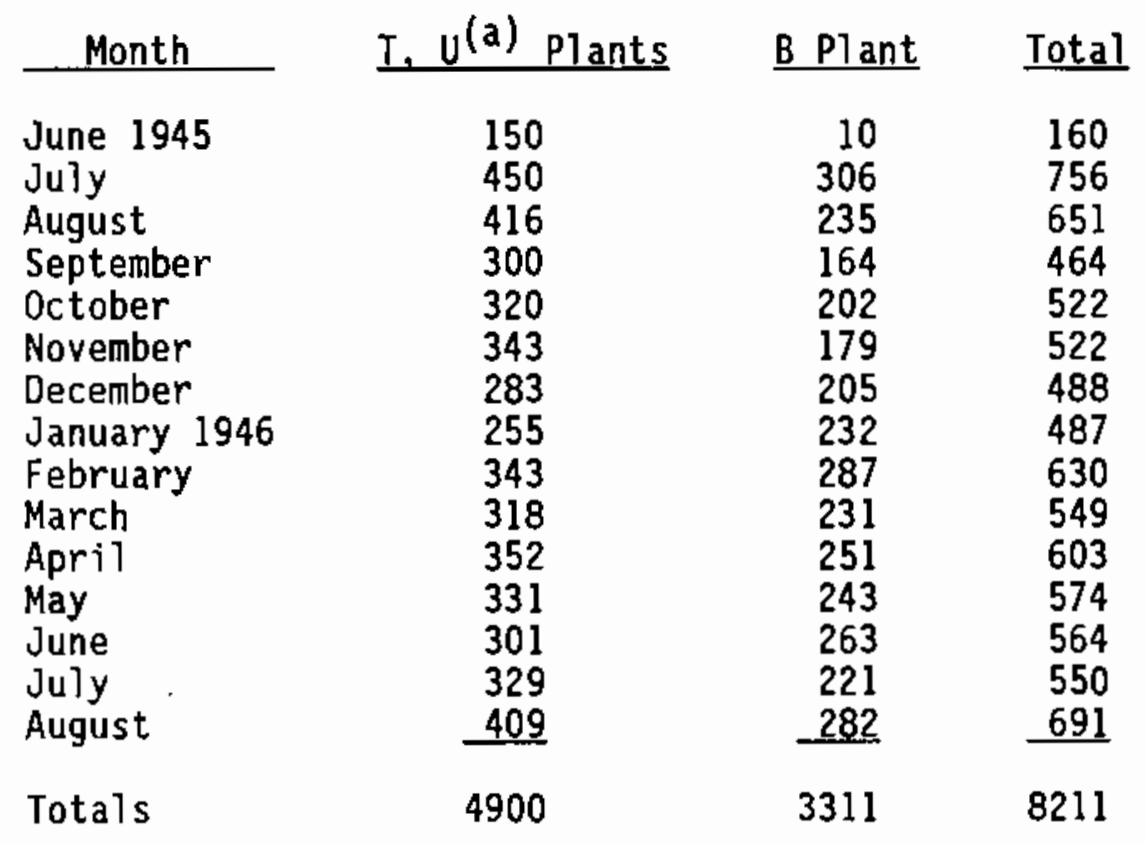

(a) U Plant was never used for fuel reprocessing. It was later used for uranium recovery operations. 
main radioactive hazard. There was also an awareness of ingestion and inhalation as potential exposure pathways, although absorption through the skin had apparently not yet been considered.

The concept of a thyroid radiation tolerance level for radioactive iodine was also being developed during the early operation of the Hanford Works. Table 2 shows the evolution of the tolerance level during the early days of the Hanford project.

The tolerance level--counts per minute on a portable instrument--was apparently used as a screening level for radioactive iodine in the thyroid. All thyroid check results were compared to the tolerance screening level as a reference on the magnitude of the result and acceptability of potential thyroid dose. There is no indication that thyroid check results were used to develop individual estimates of radioactive iodine thyroid burdens or thyroid dose. Indeed, there is no mention of portable instrument readings corresponding to iodine-131 thyroid burdens until late 1945, when thousands of thyroid check measurements had already been taken.

The earliest estimates used at Hanford on tolerable amounts of radioactive iodine in the thyroid were developed at the Metallurgical Laboratory of the University of Chicago. A report from mid-1943 gives a thyroid tolerance of $1 \mathrm{r} /$ day $(1 \mathrm{R} / \mathrm{day}$ ), and allowable air concentration (8-h exposure) of $2.5 \times 10^{-13} \mathrm{Ci} / \mathrm{cm}^{3}$ (Stone 1943). During late 1944 and early 1945, including the period of implementing the routine thyroid check program, the thyroid tolerable radiation level was $2000 \mathrm{cpm}$ on portable GM radiation detection instruments. As far as can be determined, no studies had been done previousiy to determine precisely the activity of radioactive iodine in the thyroid to which this screening level corresponded.

By the end of June 1945, a "precise calibration of the thyroid counters" had been performed (Parker 1945a). This calibration used glass vials or bottles filled with a known amount of radioactive iodine and $p l a c e d$ in a "model neck." The experimental results agreed well with prior calculations, and an iodine-131 tolerance amount of $5000 \mathrm{cpm}$ was set. The limit of detection was noted to be less than $1 / 100$ of the tolerance amount. This tolerance amount differed somewhat from the "1imiting dose" of $2000 \mathrm{cpm}$ noted at the 
IABLE 2. Early Evolution of the Thyroid Radiation Tolerance Level (Screening Level) for Iodine-13l at the Hanford Engineering Works

\begin{tabular}{|c|c|c|c|c|c|c|}
\hline Report Date & $\begin{array}{l}\text { Instrument } \\
\text { Reading } \\
\end{array}$ & $\begin{array}{l}131_{1} \text { Thyroid } \\
\text { Burden } \\
(\mu \mathrm{Ci}) \\
\end{array}$ & $\begin{array}{l}\text { Thyroid } \\
\text { Dose Rate } \\
\text { (a) }\end{array}$ & $\begin{array}{c}\text { Continuous } \\
\text { Air Concentration } \\
(\mathrm{Ci} / \mathrm{CC} \text { air) } \\
\end{array}$ & $\begin{array}{c}\text { Fraction of } \\
\text { Tolerance Amount } \\
\text { Detectable } \\
\end{array}$ & References \\
\hline $\operatorname{May} 7,1943^{(b)}$ & $N / A^{(c)}$ & N/A & $1.0 \mathrm{r} / \mathrm{day}$ & $2.5 \times 10^{-13(d)}$ & N/A & Stone et al. 1943 \\
\hline June 5,1945 & $2000 \mathrm{cpm}$ & $N / A$ & $1.0 \mathrm{r} / \mathrm{day}$ & $2.5 \times 10^{-13(d)}$ & $N / A$ & $\begin{array}{l}\text { Parker and } \\
\text { Gamertsfelder } \\
1945\end{array}$ \\
\hline June 30,1945 & $5000 \mathrm{cpm}$ & $N / A$ & $1.0 \mathrm{r} / \mathrm{day}$ & $2.5 \times 10^{-13(d)}$ & {$[1 / 100]^{(e)}$} & Parker 1945a \\
\hline October 22, 1945 & $5000 \mathrm{cpm}$ & 13.7 & $1.0 \mathrm{r} / \mathrm{day}$ & $1 \times 10^{-13(f)}$ & $1 / 100$ & $\begin{array}{l}\text { Cantril and Healy } \\
1945\end{array}$ \\
\hline December 17, 1945 & $750 \mathrm{cpm}$ & 2 & $1 \mathrm{r} /$ day & $1 \times 10^{-13(d)}$ & $1 / 20$ & Parker $1945 b$ \\
\hline July 25, 1946 & $750 \mathrm{cpm}$ & 2 & $N / A$ & N/A & $1 / 20$ & Healy 1946 \\
\hline July 23, 1953 & (g) & 0.06 & $\begin{array}{l}300 \text { mrep/ } \\
7 \text { days }\end{array}$ & $\begin{array}{l}\text { N/A } \\
\text { day }\end{array}$ & $N / A$ & $\begin{array}{l}\text { Radiation } \\
\text { Monitoring Sub- } \\
\text { Section } 1953\end{array}$ \\
\hline
\end{tabular}

\footnotetext{
(a) Dose rates given in original units; $1 \mathrm{r}$ is assumed to equal $1 \mathrm{R}$ (roentgen).

(b) From University of Chicago Metallurgical Laboratory, used at Hanford.

(c) $N / A=$ not available.

(d) 24-h exposure period.

(e) $[$ ] = implied value.

(f) 8-h exposure period.

(g) Instrument used is a gamma scintillation detector, not GM detector.
} 
beginning of June (Parker and Gamertsfelder 1945). No mention was made of the corresponding iodine-131 activity in the thyroid, or the thyroid dose rate attributable to the tolerance amount.

The $5000 \mathrm{cpm}$ tolerance amount was used throughout the summer and fall of 1945, and was reaffirmed in a more detailed report issued in October 1945 (Cantrit and Healy 1945). This report presented additional information on the medical use, research, and metabolism of iodine-131 specifically, and not simply "radioactive iodine" as had been previously mentioned. Calculations presented here show a tolerable thyroid dose rate of $1.0 \mathrm{r} /$ day, approximately equivalent to $1.2 \mathrm{rad} /$ day thyroid dose rate. The corresponding thyroid burden of iodine-131 was calculated to be $13.7 \mu \mathrm{Ci}$.

Within 2 months, by early December 1945, it was determined that previous screening levels had significantly overestimated the amount of iodine-131 in the thyroid necessary to give the tolerable thyroid radiation dose (Parker 1945b). While the tolerable thyroid dose rate was still 1.0 $\mathrm{r} /$ day $(1.2 \mathrm{rad} /$ day), the iodine- 131 thyroid burden was lowered to $2 \mu \mathrm{Ci}$. The actual field screening level was also lowered significantly, from $5000 \mathrm{cpm}$ to $750 \mathrm{cpm}$. 



\section{$\underline{\text { RECORDS }}$}

The thyroid measurement data presented in this report were taken from Personnel Meters Summary record sheets, an example of which is shown in the appendix. Approximately 20,000 of these records sheets were found in storage; more than 3500 sheets contained information on thyroid checks.

These records are considered to be unofficial for several reasons. First, E. I. du Pont de Nemours, Co., Inc., took all official records for operations when the time the company left the Hanford Engineering Works on September 1, 1946. All of these records were generated before this date. Second, there is no formal documentation on how these records were generated, where they came from, and their completeness, and no procedures or other information exist to help interpret the data.

The summary sheets appear to be a compilation of personal radiation exposure information taken from a variety of sources. Only one individual's data are on each sheet, but an individual may have more than one sheet. Each sheet was coded and the individual worker's name and payroll number removed before being made available for evaluation. Information of value for this evaluation include the Week Ending Date, Throat Check right and left readings, and record sheet code identifier. A complete listing of all available thyroid measurement data is presented in the appendix.

There are several problems with using these records. As mentioned above, these are unofficial records, and there is no formal documentation available on how to interpret any of the data contained on the sheets. There are numerous transcription errors on the record sheets, apparently made during the compilation from original logbooks or records to the summary sheets. These errors were primarily in the week-ending dates and years. (It is unknown how many other errors may also be included on the sheets.) Finaliy, because entries were handwritten and sometimes cryptic or illegible, interpretations and assumptions as to the meaning sometimes had to be made. All available data (using the assumed value where appropriate) were included in the evaluation. 



\section{SOURCES OF MEASUREMENT UNCERTAINTY}

An important consideration in using the available thyroid measurement data in the HEDR dose estimation process is the reliability of the data. Potential sources of error in the available data must be identified and, if possible, the measurement uncertainty quantified. 0ata with a low degree of reliability are of limited use in further evaluations.

Potential sources of uncertainty in the recorded measurement values are identified here. These sources may include inherent statistical variability and errors made during the measurement process, during data recording, and during data interpretation because of lack of data documentation. No effort is made in this report to quantify or estimate the bounds of potential data uncertainty.

\section{RECORDS AND MEASUREMENT DATA}

Some weaknesses in the thyroid measurement records were described previously in this report. These include lack of documentation about the origin of the records and measurement data and transcription errors and inaccuracies that cannot be identified or quantified.

The measurement data available on the records sheets have no formal documentation on how to interpret the data. From interpretation of entries in reviewed historical reports and general knowledge of radiation counting and data recording methods, it was assumed that all measurement data were recorded as net counts per minute above background. There are no records of any gross count results or background counts taken, however, and it is possible that the measurement data are reported in a different format. These other formats could include gross counts per minute, gross counts (unknown counting time), or net counts (unknown counting time). It would logically appear, however, that the recorded values would be in the same units; that is, net counts per minute, as the screening level. Also, the high number of zero results seems to indicate that background counts were subtracted out, and net counts per minute were recorded. 
The set of measurement data may also be incomplete. Thyroid checks reported in summaries from the Operating History (1946) numbered 8211, while only 7933 measurement results were noted in the examination of summary record sheets. The record sheet results also included a few measurements made in months outside the time period included in the operating history. It should be noted, however, that recovering this many measurements from 45-year-old unofficial records and having a total number of measurements taken to compare to is quite remarkable.

\section{PROCEDURES}

Not until 1953 did procedures exist that described how thyroid check measurements were taken or how results were used in the radiation protection program. Written procedures during 1944 through 1946 may or may not have existed, because the thyroid counting program was implemented very quickly. Because of the lack of detailed information on field operations, estimates and assumptions must be made about a number of important parameters. The historical reports reviewed to date provide little information on detailed field procedures.

Two specific parameters of interest are the actual counting time used and the method for subtracting background radiation. The only reference to measurement counting time is that it was short (Parker 1945b). For this evaluation, "short" was assumed to mean 1 minute for each thyroid lobe counted, a total counting time of 2 minutes. It should be noted that there were distinctly more even-numbered than odd-numbered results from the counts of both the right and left thyroid lobes. The cause of this difference is unknown, but could have resulted from some unknown equipment or human rounding or recording bias. No attempt was made to eliminate this artifact.

References to instrument background refer to the "norma]" background count or count rate. This brings up the question of whether an actual background measurement was taken each day and at each counting location, or whether a "normal" background count rate of $20 \mathrm{cpm}$ was subtracted from each result. Because nearly all measurement results (97\%) were less than 24 net 
$\mathrm{cpm}$, and screening levels during this period were 2000, 5000, and 750 net $\mathrm{cpm}$, it is understandable why a normal background result might be used. When compared to the much higher screening level value, a difference of a few counts per minute between the assumed normal rate and the actual background rate seemed trivial, particularly if there were numerous thyroid checks to be done and workers were waiting.

It is particularly relevant to note that thyroid check results were apparently not used to calculate worker thyroid burdens or doses. Thyroid check results were simply compared to a screening level (given in net counts per minute) that corresponded to the thyroid radiation tolerance amount. Health Instruments inspectors recorded the results and made the comparison to determine if the results showed an unacceptable thyroid radiation exposure.

Other unknown procedural elements that could affect the uncertainty of measurement results are the lack of information on how and where measurements were made, and the amount of training given to Health Instruments inspectors who made the measurements. The location when thyroid checks were made is important because proximity to the work area introduces the possibility of nearby radioactive material handling or airborne radioactivity contributing to measurement results. External contamination on surrounding surfaces or on the skin or clothing of workers could also contribute to measurement results.

How the detector was placed in counting the thyroid giand was also important. A calibration report (Healy 1946) noted that the particular brasswalled detector was at least twice as efficient as other available instruments. Moving the detector $30 \mathrm{~mm}$ from the isthmus of the thyroid during counting could reduce count results by $25 \%$; smaller distances from the isthmus showed correspondingly less error. Use of the appropriate detector and placement in the correct location, determined by appropriate procedures and training, could have had a significant effect on measurement results.

\section{USE OF PORTABLE INSTRUMENTS}

The use of portable or semiportable instruments for thyroid checks shows a great deal about the qualitative nature of the measurements. All counting instruments are subject to the vagaries of the environment (temperature, 
shock, humidity) and require routine source checks and periodic calibration. Portable instruments, however, tend to have less rigorously controlled calibration and maintenance checks, and are more subject to changes in counting geometry and extraneous sources of radiation.

The portable or semiportable instruments used for thyroid checks from 1944 through 1946--and also into the early 1950s--were GM detectors. These detectors operate on a total tube discharge principle and thus cannot distinguish between different types of radiation. Use of the brass-walled detector with no window eliminated any alpha radiation and most beta radiation; however, any incident gamma radiation, regardless of source, would be detected. Numerous gamna-emitting radionuclides, fission products from the reprocessed fuel, could have been detected and their signal interpreted as iodine-131. By 1953, advances in instrumentation had relegated the GM detector to a qualitative estimator role in thyroid checks, replaced by the more efficient gamma scintillation detector.

The type of counting equipment used with the detection instrument was also important. Analog count rate meters would make the task of counting much more difficult, because of the need to time the count and count pulses simultaneously. Scalers with timers would have made the task much easier. The scaler used during this time period was a binary scaler. Registers of lights gave indication of detection of counts by $1,2,4$, and 8 , with octads registered by mechanical counter.

The fact that portable or semiportable instruments were used, with their associated variability and unreliability, is more evidence that the thyroid checks were used qualitatively as indicators of worker exposure to iodine131, not to quantitatively determine the activity in the thyroid. Measurements made using these instruments are subject to uncertainty in several different areas, a fact that should be considered in any use of the measurement data.

\section{COUNTING STATISTICS}

Any measurements of radiation are subject to variability caused by the random nature of radioactive decay. This variability can be quantified 
through the use of counting statistics. Counting statistics use a number of statistical parameters, including counting time, background counts, and gross or net radiation counts. Unfortunately, this information was not provided with the thyroid measurement data, adding uncertainty even to this normally quantifiable variability. Estimates of some of these parameters can be made, however, from general references to thyroid counts made in historical reports.

Two reports (Cantril and Healy 1945; Parker 1945b) made references to the normal background count rate of the brass-walled counters used to perform the thyroid checks; this count rate was $20 \mathrm{cpm}$. Parker (1945b) a] so mentioned that the counting time was "short;" it was assumed for this report that the counting time was 1 minute for each of the thyroid lobe readings that comprised a thyroid check measurement. This total counting time is in general agreement with a later procedure for thyroid checks (1953), which used a single 2-minute thyroid counting period.

Using these estimates of thyroid check counting parameters, estimates can be made of the relative counting error. The coefficient of variation (CV) expresses the standard deviation as a function of the quantity being measured. For a count rate it is defined as (Lapp and Andrews 1963)

$$
C V=\frac{\sigma_{\mathrm{R}}}{\mathrm{R}_{\mathrm{S}}}
$$

where $C V=$ coefficient of variation of the net sample count rate

${ }^{\sigma} \mathrm{R}=$ standard deviation of the net sample count rate

$R_{S}=$ net sample count rate

Calculating $\mathrm{CV}$ in percent using the estimated standard deviation of the net sample count rate based on a single sample count and a single background 14 count is shown as

$$
C V(\%)=100\left[\frac{\frac{R_{g}}{t_{g}}+\frac{R_{b}}{t_{b}}}{R_{s}}\right]^{1 / 2}
$$


where $R_{g}=$ gross count rate of the measurement and background

$\mathrm{t}_{\mathrm{g}}=$ measurement counting time

$R_{b}=$ count rate of the background

$t_{b}=$ background counting time

$R_{s}=R_{g}-R_{b}=$ net count rate of the measurement

Figure $l$ shows $C V$ as a function of net counts per minute, assuming a 1 minute count time each for background and measurement, and assuming a background count rate of $20 \mathrm{cpm}$. At 1 net $\mathrm{cpm}$, the lowest positive result observed in the measurement data, the $\mathrm{CV}$ exceeds $600 \%$. The $\mathrm{CV}$ exceeds $100 \%$ until at least 7 net $\mathrm{cpm}$ are observed. Thus for thyroid measurement results very close to zero, the variability inherent in the measurements is relatively high, but is quantitatively rather smal1. One net $\mathrm{cpm} \pm 1 \mathrm{CV}$ ranges from 0 to 6 net cpm (negative results are not included); 7 net cpm $\pm \mathrm{CV}$ ranges from 0 to 14 net cpm. Low counting results remain low even when the counting variability is considered.

The decision limit and detection limit (NCRP 1978) for the thyroid measurements can be estimated by knowing the total background counts, or background count rate and background count time. The decision limit $\left(L_{C}\right)$ is the net number of counts for reaching a decision of no detection (not positive) if the actual net counts are less than $L_{\mathcal{C}}$, and reaching a decision of signal detection (positive) if the actual net counts are greater than $L_{C}$. It is established a priori by fixing an acceptable level of false positive; that activity is detected but in reality none exists. The level usually selected is 0.05 , meaning that, on the average, $5 \%$ of the measurements made on a person with no internal radioiodine would be expected to result in the erroneous conclusion that the radioiodine was present in the thyroid.

Like $L_{C}$, the detection limit $\left(L_{D}\right)$, or lower limit of detection (LLD) (Watson 1980) is also established a priori. It is directly proportional to the standard deviation of the background count rate. $L_{D}$ is set by fixing an acceptable level of false nondetection; that is, setting a level at which no signal is detected, but one actually exists. This level is generally set at 0.05 , meaning the probability of not detecting a truly positive count at the detection level is $5 \%$. The probability of detecting activity present in a 


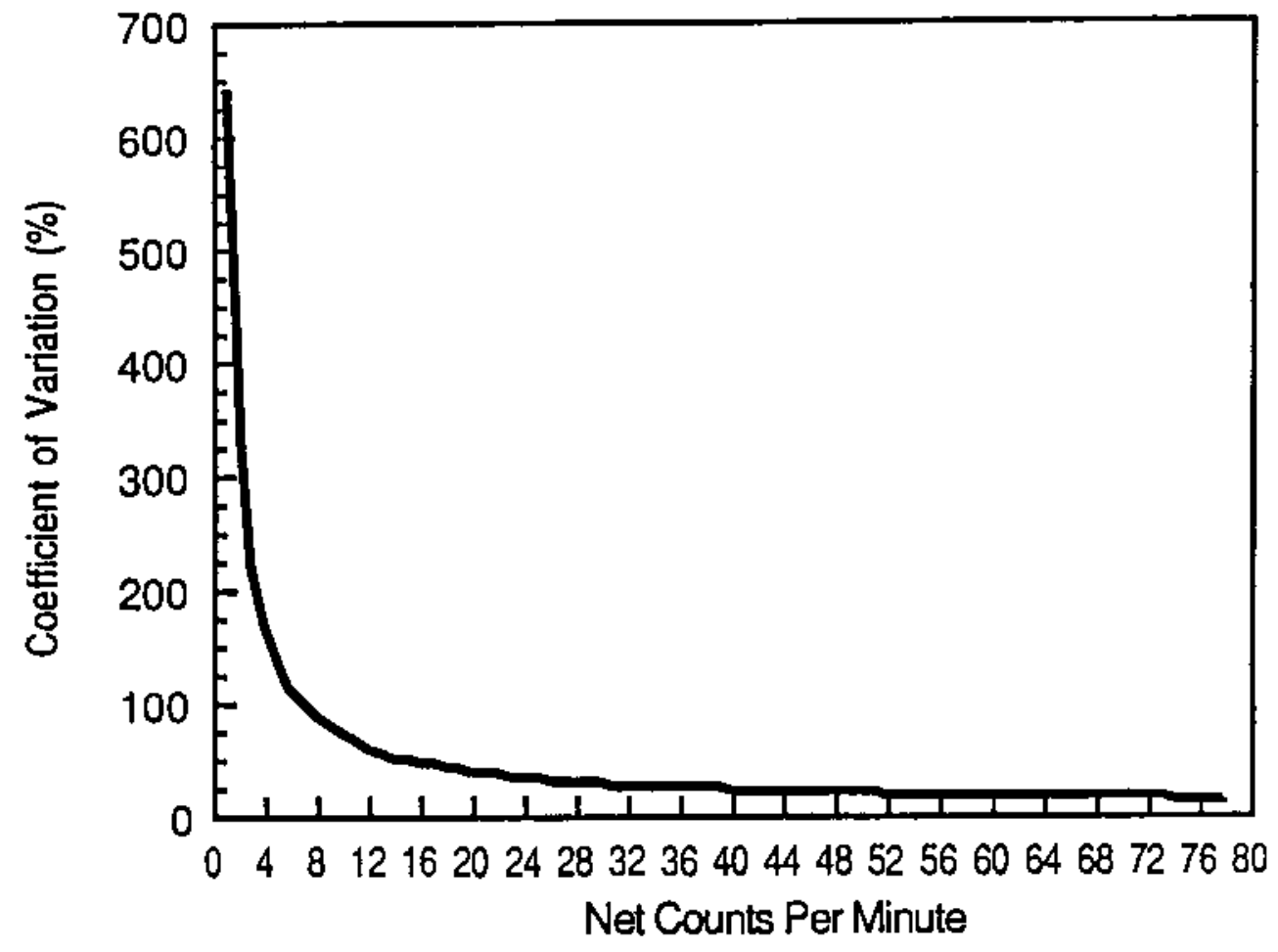

FIGURE 1. Relative Counting Error of Thyroid Measurements

sample in an amount equal to the detection level is therefore $95 \%$. At the detection limit the count is likely (95\%) to be detected; as the activity in the sample is farther and farther below $L_{D}$, the detection becomes less probable. Similarly, as the level in the sample increases above the $L_{D}$, the detection probability increases.

The $L_{D}$ (or LLD) can be used as a guidepost to the detection capability of the instrument being used. Assuming use of the brass-walled GM detector with a normal background count rate of $20 \mathrm{cpm}$ and a count time of 1 minute, the $L_{C}$ and $L_{D}$ can be estimated as $L_{C}(\alpha=0.05), 10 \mathrm{cpm}$ (assumes $20 \mathrm{cpm}$ background count rate, 1 -minute count time; counts per minutes rounded to nearest integer value); $L_{D}(\beta=0.05), 24 \mathrm{cpm}$ (assumes $20 \mathrm{cpm}$ background count rate, 1 -minute count time; counts per minutes rounded to nearest integer value). Consideration of the $L_{C}$ and $L_{D}$ shows that there is uncertainty in determining whether or not measurement results close to zero are actually positive or not. 
Taken into consideration with the counting error of the lower results, it is uncertain if thyroid check results less than 10 net cpm actualiy represent actual measurements of radioactivity in the thyroid.

It should be understood that relatively large measurement uncertainty is expected at and below the detection limit. Large measurement uncertainty for these low measurement results means that the actual presence of radioactivity is statistically uncertain, and not that there is some inherent flaw with the thyroid monitoring program. 


\section{EVALUATION}

Initial stages of this evaluation consisted of compiling the available measurement records and putting the data into a usable form. The Pacific Northwest Laboratory Radiation Exposure Records Group located available Personnel Meters Summary record sheets and examined them for thyroid measurement data. Records containing thyroid data were photocopied, the employee names and payroll numbers removed, and the records forwarded for evaluation of the measurement data. All thyroid check measurement data on the summary records sheets were entered into a data base and $100 \%$ independently verified to ensure that data entry was correct.

Evaluations were performed on the complete set of measurement data; each result was considered to be an independent event, and no attempt was made to correlate them to individuals or make individual estimates of thyroid burden or dose. Al1 results were included in the evaluations, including those that required interpretation from the record sheets. There were several measurement results that showed large differences between left and right readings of a measurement (e.g., 0 and 15). Ideally, left and right readings should be identical. These disparate reading results are difficult to explain, because radiation from one lobe of the thyroid may contribute approximately 20 to $30 \%$ of a count taken on the other lobe. Although readings of this type may in fact indicate a false positive result, no attempt was made to exclude any of these results. No accounting was made for potential differences in physical structure or metabolism between the lobes of the thyroid that could account for the differences. Also, an objective of this report was to present all available data, regardless of the uncertainty that could be associated with any of these measurements. In a similar sense, all of the very low measurement results are presented, although there may be a considerable degree of uncertainty in these measurements.

All evaluations of thyroid check results were conducted on the average of the right and left readings for each measurement. While evaluations could have been done on any of several parameters (right alone, left alone, sum of right and left, etc.), using the average has the advantage of bejng the most 
consistent measurement and most easily converted to a estimate of thyroid burden. Use of an average value also makes the results directly comparable to the results of the calibration report for iodine-131 in the thyroid (Healy 1946). No significant difference was found between counts of either the right and left lobes of a thyroid phantom compared to a count taken centraily between the lobes. Therefore, the average of all measurements was used in making the conversion from instrument counts per minute to $\mu \mathrm{Ci}$ of iodine-131 in the thyroid. 


\section{RESULTS AND DISCUSSION}

Results of 7933 thyroid check measurements were identified and included in this evaluation. These results represent thyroid checks taken on nearly 1600 individual Hanford workers during 1944, 1945, and 1946.

Thyroid check measurement dates found in the summary records ranged from October 1944 to September 1946. Only week-ending dates were available for the measurements, with the earliest record of any thyroid check measurement for the week ending 0ctober 1, 1944. Relatively few thyroid checks were made during the period from October 1944 through May 1945. The occurrence of two plume events at the end of May 1945 and the implementation of a routine thyroid check program are reflected in a dramatic rise in the number of thyroid check measurements in June and July 1945, shown in Table 3 . The high number of monthly thyroid checks, ranging from 450 to 750 , continued through August 1946. Greater than $99 \%$ of all available records had measurement dates from June 1945 through August 1946.

Table 3 presents the approximate monthly distribution of thyroid checks taken from the summary records and compared to monthly totals in the operating history document. The operating history gives no indication of any thyroid checks before June 1945 . This may be because the operating history includes only the thyroid checks made as part of the routine thyroid measurement program, or because the thyroid checks appearing from October 1944 into May 1945 are due to transcription errors made in compiling the summary sheets.

Differences exist between the monthly totals of the summary records and the operating history for two reasons. The thyroid check results of the summary records are available only by week-ending date; therefore, a monthly tabulation of these results is only approximate. Only 7933 thyroid check results were found in the summary records, compared to the 8211 thyroid checks reported in the operating history, a apparent discrepancy of 278 measurement results. The difference may be due to a simple accounting error in the operating history summaries or to missing measurement records. Although the 
IABLE 3. Number of Thyroid Check Measurements Performed Per Month

\begin{tabular}{|c|c|c|}
\hline Month & $\begin{array}{l}\text { Thyroid Check } \\
\text { Measurement Records (a) }\end{array}$ & $\begin{array}{c}\text { Operatipg History } \\
\text { Document }\end{array}$ \\
\hline $\begin{array}{l}\text { October } 1944 \\
\text { November } \\
\text { December } \\
\text { January } 1945 \\
\text { February } \\
\text { March } \\
\text { Apri1 } \\
\text { May } \\
\text { June } \\
\text { July } \\
\text { August } \\
\text { September } \\
\text { October } \\
\text { November } \\
\text { December } \\
\text { January } 1946 \\
\text { February } \\
\text { March } \\
\text { Apri1 } \\
\text { May } \\
\text { June } \\
\text { July } \\
\text { August } \\
\text { September }\end{array}$ & $\begin{array}{r}3 \\
3 \\
4 \\
2 \\
9 \\
4 \\
10 \\
13 \\
252 \\
636 \\
516 \\
534 \\
513 \\
479 \\
546 \\
469 \\
543 \\
680 \\
512 \\
504 \\
591 \\
538 \\
570 \\
2 \\
\end{array}$ & $\begin{array}{l}160 \\
756 \\
651 \\
464 \\
522 \\
522 \\
488 \\
487 \\
630 \\
549 \\
603 \\
574 \\
564 \\
550 \\
691\end{array}$ \\
\hline TOTALS & 7933 & 8211 \\
\hline
\end{tabular}

(a) Approximate monthly totals, estimated from week ending dates.

(b) Operating History (1946).

results found represent more than $96 \%$ of the thyroid checks reported in the operating history, the results may still represent an incomplete data set.

There is an artificial end to thyroid check results data in September, 1946. On September 1, 1946, E. I. du Pont de Nemours, Co., Inc., discontinued its Hanford Engineer Works operating contract and left the Hanford reservation, taking all official records. General Electric Company became the new operating contractor, and the compilation of the summary record sheets apparently ended at this time. Thyroid checks continued under General 
Electric Company, however, as indicated by the December 1946 monthly report (Parker 1947), which noted 6766 total checks for 1946 . More than 2100 additional thyroid checks were made from September through December 1946. Additional thyroid check data may be available for the months after August 1946; however, data are contained within each individual workers file, and are not available as a readily reviewed compilation of data as found in the summary records.

The distribution of the thyroid check measurement results is shown in Table 4. These results are assumed to be net count rates, or the counts per minute above the normal background. Each result is the average of the two readings taken during each measurement, one reading on the left and right lobes of the thyroid gland. Fractions of 0.5 or higher were rounded to the next higher integer.

The most striking feature of this data distribution is the preponderance of low net count rate results. Over $36 \%$ of the results were $0 \mathrm{cpm}$, and nearly $80 \%$ were less than 5 net cpm. Since the normal background count rate was reported as being about $20 \mathrm{cpm}$, more than $98 \%$ of all results are within a factor of two of normal background $(20$ net $\mathrm{cpm})$. There were no results reported as being less than zero, which is not unusual considering how radiation surveys were recorded. Counts less than zero were called zero for convenience, although to be statistically correct the negative values should have been recorded. It is likely that the procedure used during this period called for reporting less than zero results as zero, thus resulting in a positive bias in the measurement results.

This distribution of results can be evaluated using the $L_{C}$ parameter determined previously. The $L_{C}$ is that level where a determination is made, with $95 \%$ confidence, that a result does or does not indicate the presence of activity. Ninety-three percent of all measurement results were at or below the decision 1 imit of 10 net cpm. Therefore, there is $95 \%$ confidence that $7 \%$ of all results greater than 10 net cpm are actually positive and may represent the presence of radioactive iodine in the thyroid. For 93\% of all results that are less than 10 net $\mathrm{cpm}$, the confidence in the measurement result becomes less and less as it gets closer to 0 net cpm and farther 
IABLE 4. Distribution of Thyroid Check Observed Net Count Rate Results

\begin{tabular}{|c|c|c|c|}
\hline $\begin{array}{l}\text { Net } \\
\text { CPM }\end{array}$ & $\begin{array}{l}\text { Number of } \\
\text { Results }\end{array}$ & $\begin{array}{l}\text { Percent of } \\
\text { Iotal Results }\end{array}$ & $\begin{array}{l}\text { Cumulat ive } \\
\text { Percent }\end{array}$ \\
\hline 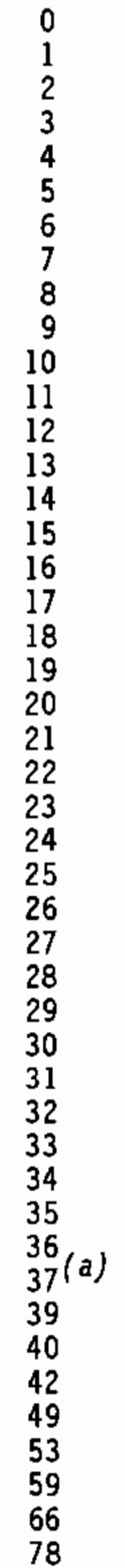 & $\begin{array}{r}2877 \\
972 \\
883 \\
673 \\
610 \\
344 \\
343 \\
225 \\
192 \\
131 \\
126 \\
95 \\
104 \\
60 \\
45 \\
33 \\
31 \\
32 \\
14 \\
15 \\
10 \\
15 \\
15 \\
13 \\
7 \\
9 \\
7 \\
6 \\
4 \\
1 \\
7 \\
4 \\
4 \\
3 \\
4 \\
2 \\
2 \\
4 \\
1 \\
1 \\
3 \\
3 \\
1 \\
1 \\
2 \\
1 \\
1\end{array}$ & $\begin{array}{r}36.3 \\
12.3 \\
11.1 \\
8.5 \\
7.7 \\
4.3 \\
4.3 \\
2.8 \\
2.4 \\
1.7 \\
1.6 \\
1.2 \\
1.3 \\
0.8 \\
0.6 \\
0.4 \\
0.4 \\
0.4 \\
0.2 \\
0.2 \\
0.1 \\
0.2 \\
0.2 \\
0.2 \\
0.1 \\
0.1 \\
0.1 \\
0.1 \\
0.1 \\
0.0 \\
0.1 \\
0.1 \\
0.1 \\
0.0 \\
0.1 \\
0.0 \\
0.0 \\
0.1 \\
0.0 \\
0.0 \\
0.0 \\
0.0 \\
0.0 \\
0.0 \\
0.0 \\
0.0 \\
\end{array}$ & $\begin{array}{r}36.3 \\
48.5 \\
59.6 \\
68.1 \\
75.8 \\
80.2 \\
84.5 \\
87.3 \\
89.7 \\
91.4 \\
93.0 \\
94.2 \\
95.5 \\
96.2 \\
96.8 \\
97.2 \\
97.6 \\
98.0 \\
98.2 \\
98.4 \\
98.5 \\
98.7 \\
98.9 \\
99.1 \\
99.1 \\
99.3 \\
99.3 \\
99.4 \\
99.5 \\
99.5 \\
99.6 \\
99.6 \\
99.7 \\
99.7 \\
99.8 \\
99.8 \\
99.8 \\
99.9 \\
99.9 \\
99.9 \\
99.9 \\
99.9 \\
99.9 \\
99.9 \\
99.9 \\
100.0\end{array}$ \\
\hline
\end{tabular}
because values without results are not included. 
from 10 net $\mathrm{cpm}$. The confidence in the lower results can be evaluated by considering the coefficient of variation, or relative counting error also discussed above. Results less than 7 net cpm have counting error of greater than $100 \%$, not considering other sources of uncertainty. All results are subject to other uncertainties such as counting instrument variability, procedural unknowns, and record error.

Even results higher than the lower limit of detection, although less uncertain from a statistical point of view, are subject to other potential sources of error. For example, radiation that is detected and thought to indicate the presence of radioactive iodine in the thyroid may in fact be from some other source. In reviewing the highest count rate results of Table 4 , those greater than 40 net cpm, it appeared that the highest five results and six of the highest nine results reviewed were actually due to external contamination and not to radioactive iodine in the thyroid.

External contamination is radioactive material that is present on the skin, hair, or clothing and is not present in the thyroid gland itself. The presence of external contamination is revealed by several thyroid check results occurring in the same week (and written in the same entry field), with the highest results first and differing from subsequent results by factors of 5 to 10 or more. The lowest variability and thus best counting statistics are seen at the higher count rates, and truly positive results (radioactive iodine in the thyroid) would not be expected to change by more than $30 \%$ to $50 \%$ per week, including the portable instrument variability.

By not including the above results, which were apparently due to external contamination, the highest result that could have come from radioactive iodine in the thyroid is $49 \mathrm{cpm}$. Other thyroid check results, which were not high enough to warrant recounting and thus be detectable in the records, may also be due to external contamination. If all activity is assumed to be from iodine-131 in the thyroid, the potential thyroid burden is overestimated.

Information is available that makes it possible to estimate the radioactive iodine thyroid burdens, meaning the activity of radioactive iodine present in the thyroid gland. A calibration report was issued in July 1946 (Healy 1946) to back up an earlier revision of thyroid radiation tolerance 
amount and screening level (Parker 1945b). The calibration report shows $375 \mathrm{cpm}$ on the brass-walled GM detector to be equivalent to $1 \mu \mathrm{Ci}$ of iodine-13l in the thyroid. If it is assumed that all measurements were taken using a brass-walled GM detector, and all results are due to the presence of iodine-131 in the thyroid, measurement results can be converted to estimated activity of iodine-131 in the thyroid. Table 5 shows the distribution of estimated jodine-131 thyroid burdens. There are only 7927 estimated thyroid burdens, because the six observed results caused by external contamination were not indicative of a true thyroid burden and were not included.

Because the $750-\mathrm{cpm}$ screening level was shown to correspond to an iodine-131 thyroid burden of $2{ }_{\mu} \mathrm{Ci}$ (Healy 1946), other lower results indicate a thyroid burden in the same proportion to the $2-\mu \mathrm{C} i$ thyroid burden as the measurement result is to the 750-cpm screening level. For example, the highest result, $49 \mathrm{cpm}$, is $6.5 \%$ of $750 \mathrm{cpm}$. The iodine-131 thyroid burden indicated by this count rate would be $6.5 \%$ of $2{ }_{\mu} \mathrm{Ci}$, or $130 \mathrm{nCi}\left(0.13{ }_{\mu} \mathrm{Ci}\right)$.

Table 5 is very similar to Table 4 , as it is a sjmple, direct conversion from net count rate results to estimated iodine-131 thyroid burdens. Again, the most striking feature of the distribution is the amount of very low results close to background. More than $36 \%$ of results indicate no thyroid burden, and more than $90 \%$ of the indicated iodine-131 thyroid burdens are less than $24 \mathrm{nCi}(0.024 \mu \mathrm{Ci})$.

A11 measurement results and derived quantities, such as thyroid burden, are subject to some degree of uncertainty. Much of the uncertainty, such as that resulting from record error, lack of detailed procedural information, instrument error, other sources of radiation, etc., can only be identified qualitatively. In only a few cases, such as the identification of those few results that were due to external contamination, can this uncertainty be identified and the data rejected.

Some of the uncertainty can be quantified, through the use of counting statistics. Counting statistics cannot be used, however, to eliminate some data results as "unacceptable;" the statistics simply give an indication of the data variability and thus help define the confidence one has in the data. The presentation of the coefficients of variation and lower limit of 
TABLE 5. Distribution of Estimated Iodine-131 Thyroid Burdens

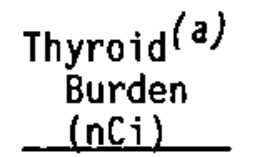

\section{0}

3

8

11

13

16

19

21

24

27

29

32

35

37

40

43

45

48

51

53

56

59

61

64

67

69

72

75

77

80

83

85

88

91

93

96

99

104

107

112

131

\author{
Number $(b)$ \\ of Results
}

2877

972

883

673

610

344

343

225

192

131

126

95

104

60

45

33

31

32

14

15

10

15

15

13

7

9

7

6

4

1

7

4

4

3

4

2

2

4

I

1

1
Percent of

Total Results

36.3

12.3

11.1

8.5

7.7

4.3

4.3

2.8

2.4

1.7

1.6

1.2

1.3

0.8

0.6

0.4

0.4

0.4

0.2

0.2

0.1

0.2

0.2

0.2

0.1

0.1

0.1

0.1

0.1

0.0

0.1

0.1

0.1

0.0

0.1

0.0

0.0

0.1

0.0

0.0

0.0

0.0
Cumulative

Percent

36.3

48.5

59.6

68.1

75.8

80.2

84.5

87.3

89.7

91.4

93.0

94.2

95.5

96.2

96.8

97.2

97.6

98.0

98.2

98.4

98.5

98.7

98.9

99.1

99.1

99.3

99.3

99.4

99.5

99.5

99.6

99.6

99.7

99.7

99.8

99.8

99.8

99.9

99.9

99.9

99.9

100.0

15

(a) Thyroid burden is estimated using the average of right and left thyroid scan results. Thyroid burden values are not sequential because values without results are not included.

(b) Six results attributed to external contamination are not included (see text). 
detection and comparison to this data set should therefore be considered only as guideposts, and not as criteria for rejecting or accepting the data. The LD (or LLD) in particular is to be used in an a priori manner; it is not intended to be used as an a posteriori criterion for presence or absence of activity (Watson 1980).

There are several areas of uncertainty in the thyroid check measurement data that have been discussed previously. These uncertainties limit the conclusions that may be drawn from these data. A large part of this uncertainty is due to attempting to use the data in a manner for which it was not intended. The original intent in 1945 for making these thyroid measurement was not to make estimates of thyroid burden or thyroid dose, but to compare to a thyroid radiation tolerance screening level and make a decision of acceptable or unacceptable thyroid occupational exposure. Because all results were far below this level, only cursory attention may have been paid to procedural monitoring or recording details. There was no intent to provide information about the exposure pathway, and one cannot differentiate environmental from occupational sources of jodine-13l; in fact, no information specifically points to iodine-131 as the source of the radiation. Only the tendency of radioiodines to accumulate in the thyroid, and the relatively long half-1 ife of iodine-131 compared to most other iodine isotopes point to iodine-131 as the most likely source of the radiation.

Evaluation of the thyroid radioactivity measurement data revealed the majority of net count rate results to be low, and iodine-131 thyroid burdens estimated from the results to likewise be low. Because the bulk of the results are quite low, the degree of uncertainty associated with these measurements is relatively large. Measurement uncertainty is due to potential measurement, instrument, recording, and interpretation errors, as well as statistical variability. The highest uncertainty resides in those results closest to zero that comprise most of the available data; greater than 90 of the data could be characterized as having associated uncertainty qualitatively described as relatively high. Because most of the measurement results were so low, even a relatively high uncertainty still leads to the conclusion that the results and their corresponding thyroid burdens were low. To be able 
to make more detailed conclusions about this data, however, the data uncertainty must be better defined. Even then, lack of thyroid check information may 1 imit any further conclusions that can be made. 



\section{QUALITY ASSURANCE}

The work described in this report was performed in accordance with the requirements of ANSI/ASME NQA-1 1986 Edition, Quality Assurance Program Requirements for Nuclear Facilities, as interpreted by PNL's Quality Assurance Program. All data base operations and data evaluation were also performed in accordance with this document. All thyroid check measurement data on the summary records sheets were entered into a data base and $100 \%$ independently verified to ensure that data entry was correct.

Drafts of this document underwent internal independent technical review. Comments from the reviewers were satisfactorily resolved, and there were no controversial resolutions to the coments.

Available records were reviewed several times to assure that all record sheets containing thyroid measurements were located. When more than 5000 records were reviewed, only three records were found that contained unlocated thyroid data, an implied Tocation efficiency of $99.98 \%$. Measurement data on the three sheets were entered into the data base and included in all data evaluations. 



\section{REFERENCES}

Cantril, S. T., and J. W. Healy. 1945. Iodine Metabolism with Reference to I3I. HW-7-2604, Hanford Works, Richland, Washington.

Healy, J. W. 1946. Detection of 131 I in the Body. HW-7-4451, Hanford Works, Richl and, Washington.

Howe11, W. P., J. L. Kenoyer, M. L. Kress, K. L. Swinth, C. D. Corbit, L. V. Zuerner, D. M. Fleming, and H. W. DeHaven. 1989. A Historical Review of Portable Health Physics Instruments and Their Use in Radiation Protection Programs at Hanford, 1944 Through 1988. PNL-6980. Pacific Northwest Laboratory, Richland, Washington.

Lapp, R. E., and H. L. Andrews. 1963. Nuclear Radiation Physics. PrenticeHall, Inc. Englewood Cliffs, New Jersey. 413 pages.

National Council on Radiation Protection and Measurements. 1978. A Handbook of Radioactivity Measurements Procedures. NCRP Report 58, National Council on Radiation Protection and Measurements, Washington, D.C.

Operating History, Hanford Engineer Works 1944 - 1946. 1946. Medical Department, Heal th Instruments Section, Book 7. HAN-73214-BK7-DEL, Hanford Works, Richland, Washington.

Parker, H. M., and C. C. Gamertsfelder. 1945. Weekly H. I. Reports on 200 Area and Environs for 1-5-45 Through 2-13-46. HW-7-1115-DEL, Hanford Works, Richland, Washington.

Parker, H. M. 1945a. Monthly Reports - H. 1. Section - For 1945.

HW-7-1228-DEL, Hanford Works, Richland, Washington.

Parker, H. M. 1945b. Proposed Revision of Tolerances for 131 I. HW-7-3042, Hanford Works, Richland, Washington.

Parker, H. M. 1947. H. l. Section Report for December 1946. Hanford Atomic Products Operation, Richland, Washington.

Radiation Monitoring Sub-Section, Separations Section, Manufacturing Department. 1953. Manual of Radiation Monitoring Practices. (with revisions through Apri1 15, 1956). HW-28802, Hanford Atomic Products Operation, Richland, Washington.

Stainken, F. A. R. 1948. Primary Report on the Chronology of the Separations Plant Stack Discharge Active Particle Contamination Problem at Hanford Works. HW-11082, Hanford Atomic Products Operation, Richland, Washington. 
Stone, R. S., et a7. 1943. Health, Radiation, and Protection Report for Month Ending May 7, 1943. CH-630, University of Chicago Metallurgical Laboratory.

Watson, J. E., Chairman. 1980. Upgrading Environmental Radiation Data Health Physics Society Committee Report HPSR-1 (1980). EPA 520/1-80-012, Office of Radiation Programs, U.S. Environmental Protection Agency, Washington, D. C.

Wilson, R. H. 1987. Historical Review of Personnel Dosimetry Development and its Use in Radiation Protection Programs at Hanford 1944 to the 1980s. PNL6125, Pacific Northwest Laboratory, Richland, Washington. 
APPENDIX $A$

THYROID MEASUREMENT DATA 


\section{APPENDIX $A$}

\section{THYROID MEASUREMENT DATA}

All thyroid measurement data were taken from Personnel Meters Summary record sheets, a typical example of which is shown in Figure A.l. Information taken from these record sheets includes the Week Ending Date (column 1) and Throat Check - right and left - entries (columns 14 and 15). Throat Check was assumed to mean thyroid check, with right and left representing the net counts per minute observed from the right and left thyroid lobes, respectively.

A11 individual identifying information (name, payroll number) was removed from the record sheets so that a blind evaluation was conducted. Each record sheet was coded using the letter and number designator found at the upper left-hand corner of the form. The record in Figure A.1 is coded C458.

Table A.1 is a complete listing of all thyroid measurement data used in this evaluation. Data are ordered primarily by the record sheet code number, and secondarily by the week-ending dates of measurements on that record sheet. Each record sheet may have more than one recorded measurement, and consecutively coded record sheets may or may not represent the same individual. 


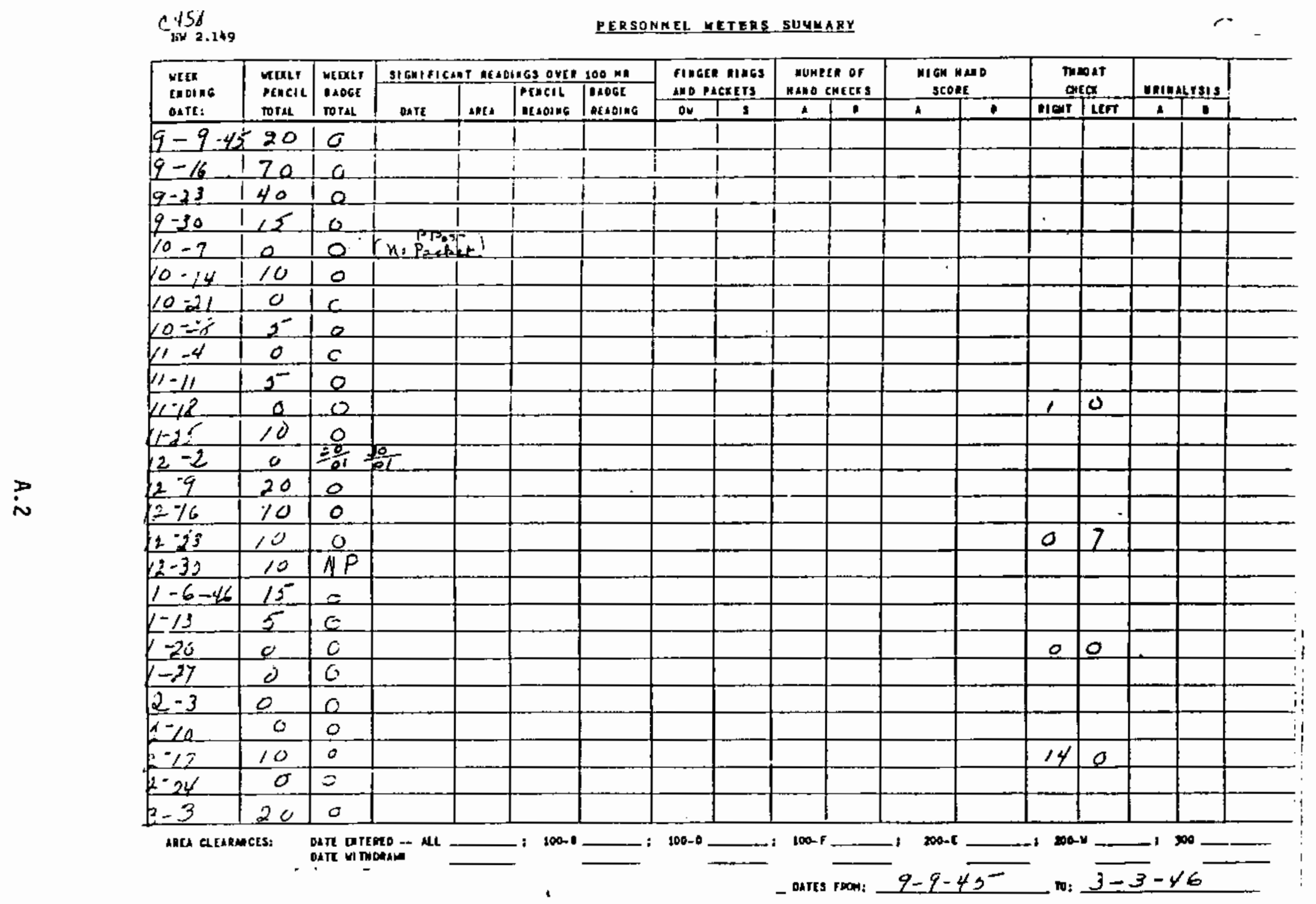

FIGURE A.1. Typical Personnel Meters Summary Record Sheet 
TABLE_A.1. Listing of Thyroid Measurement Data from Hanford Workers, 1944-1946

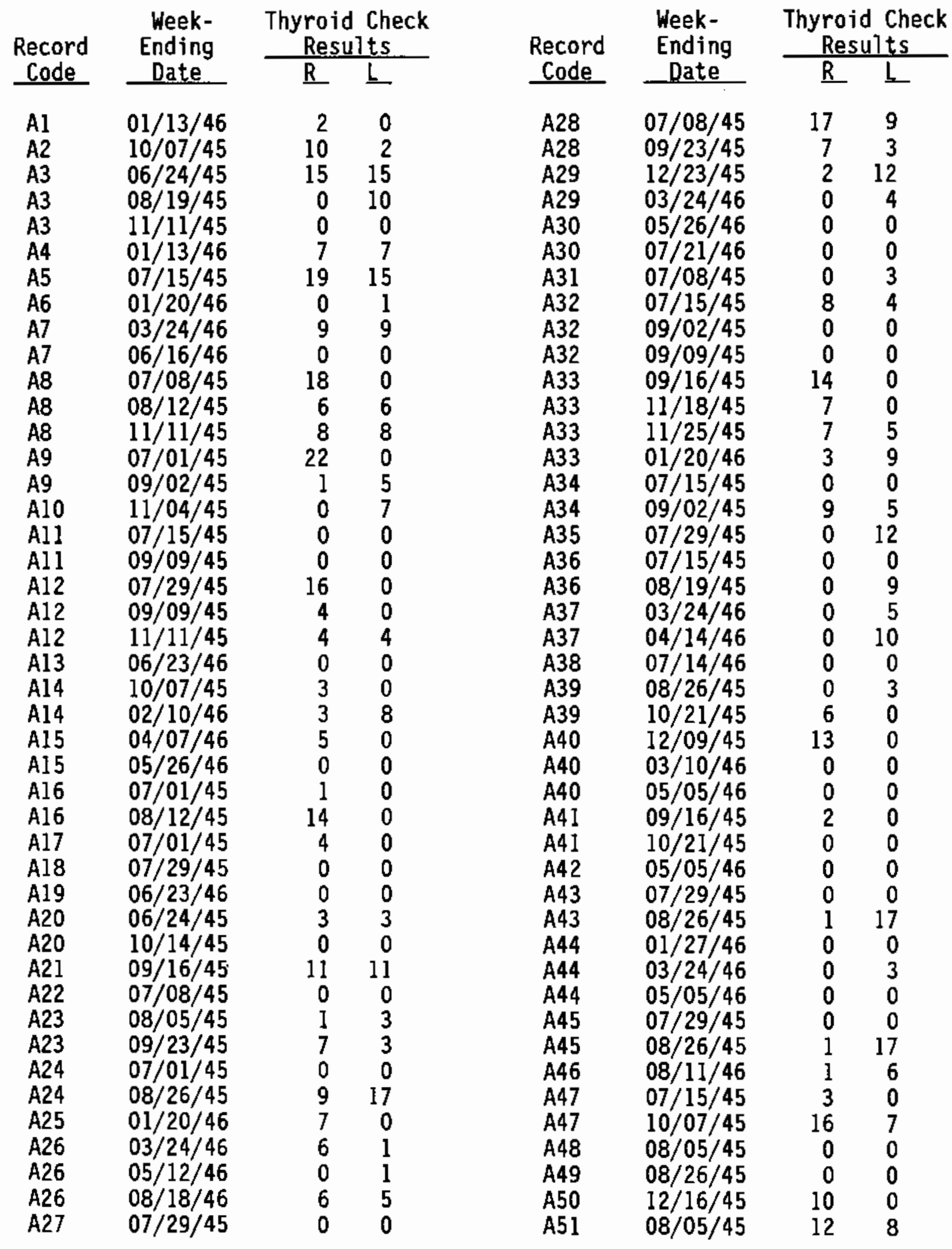


TABLE A.1. (contd)

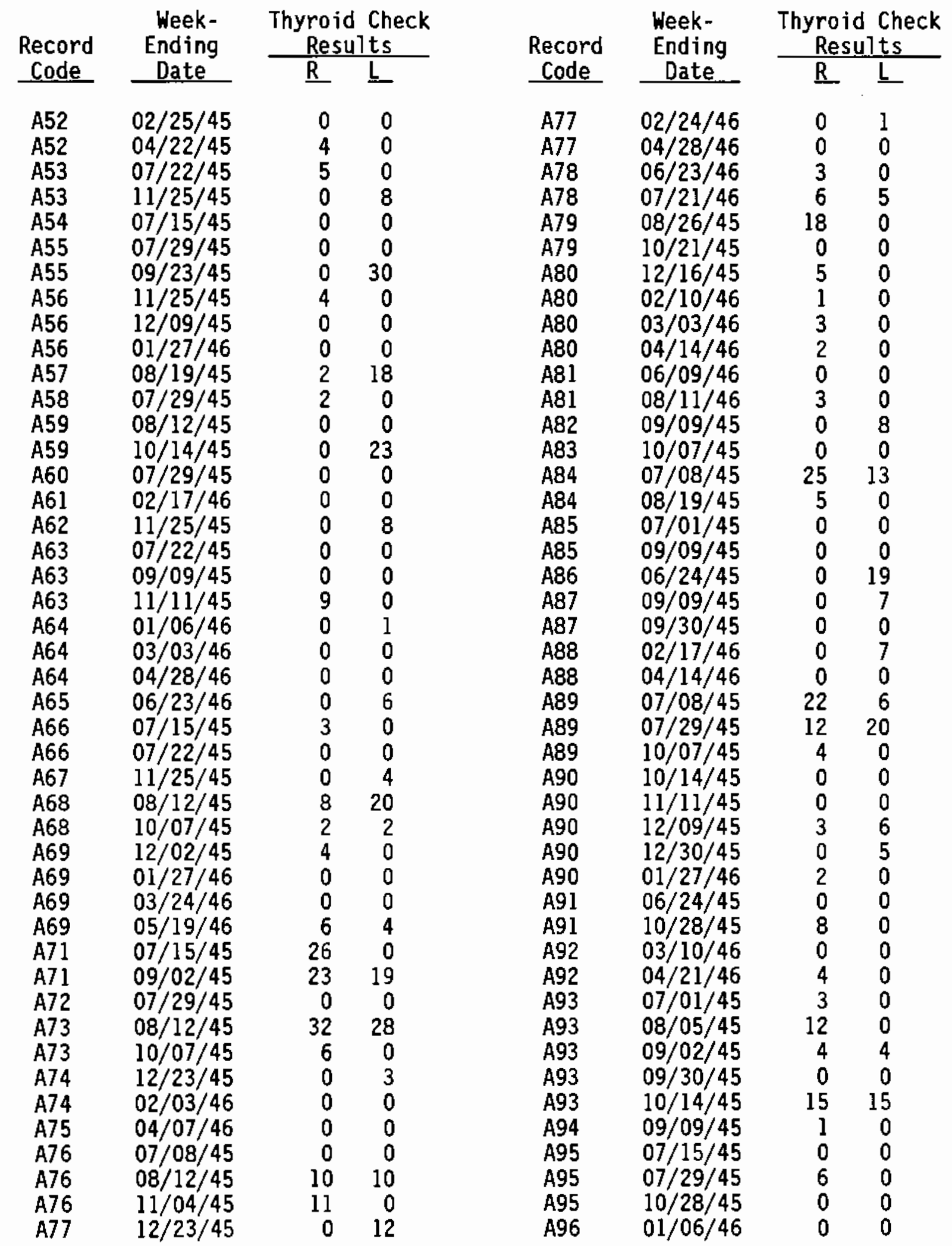


TABLE A.1. (contd)

\begin{tabular}{|c|c|c|c|c|c|c|}
\hline \multirow{2}{*}{$\begin{array}{c}\text { Record } \\
\text { Code }\end{array}$} & $\begin{array}{l}\text { Week- } \\
\text { Ending }\end{array}$ & $\begin{array}{l}\text { Thyroid Check } \\
\text { Results }\end{array}$ & \multirow{2}{*}{$\begin{array}{l}\text { Record } \\
\text { Code }\end{array}$} & \multirow{2}{*}{$\begin{array}{l}\text { Week- } \\
\text { Ending } \\
\text { Date }\end{array}$} & \multicolumn{2}{|c|}{$\begin{array}{c}\text { Thyroid Check } \\
\text { Results }\end{array}$} \\
\hline & Date & $\begin{array}{ll}\mathrm{R} & \mathrm{L}\end{array}$ & & & R & $\underline{L}$ \\
\hline A97 & $08 / 12 / 45$ & 5 & A123 & $07 / 08 / 45$ & 0 & 0 \\
\hline A97 & $10 / 28 / 45$ & 2 & A123 & $09 / 16 / 45$ & 0 & 12 \\
\hline A98 & $12 / 23 / 45$ & 2 & Al24 & $12 / 09 / 45$ & 7 & 11 \\
\hline A98 & $02 / 17 / 46$ & 5 & $\mathrm{Al} 24$ & $02 / 24 / 46$ & 12 & 6 \\
\hline A9B & $04 / 14 / 46$ & 6 & Al25 & $06 / 09 / 46$ & 1 & 1 \\
\hline A99 & $06 / 09 / 46$ & 0 & A126 & $07 / 01 / 45$ & 6 & 2 \\
\hline Al00 & $09 / 30 / 45$ & 14 & $\mathrm{Al} 27$ & $07 / 01 / 45$ & 0 & 12 \\
\hline A100 & $12 / 02 / 45$ & 28 & Al 28 & $07 / 08 / 45$ & 0 & 0 \\
\hline A101 & $06 / 24 / 45$ & 7 & Al28 & $09 / 23 / 45$ & 0 & 0 \\
\hline Alol & $07 / 15 / 45$ & 0 & $\mathrm{Al} 28$ & $11 / 18 / 45$ & 17 & 5 \\
\hline Al01 & $07 / 22 / 45$ & 16 & Al29 & $07 / 08 / 45$ & 0 & 0 \\
\hline A10l & $07 / 29 / 45$ & 0 & $\mathrm{Al} 29$ & $09 / 23 / 45$ & 0 & 0 \\
\hline Alol & $10 / 28 / 45$ & 1 & A129 & $11 / 18 / 45$ & 17 & 5 \\
\hline Alol & $11 / 18 / 45$ & 0 & $\mathrm{Al} 30$ & $01 / 13 / 46$ & 46 & 38 \\
\hline A102 & $07 / 01 / 45$ & 2 & Al 30 & $01 / 13 / 46$ & 0 & 30 \\
\hline $\mathrm{AlO} 2$ & $08 / 12 / 45$ & 42 & A130 & $03 / 10 / 46$ & 0 & 0 \\
\hline A102 & $09 / 23 / 45$ & 10 & Al 30 & $05 / 05 / 46$ & 0 & 0 \\
\hline Al03 & $12 / 16 / 45$ & 12 & Al31 & $03 / 10 / 46$ & 0 & 3 \\
\hline Al04 & $10 / 28 / 45$ & 3 & $\mathrm{Al} 31$ & $05 / 19 / 46$ & 0 & 0 \\
\hline Al05 & $12 / 23 / 45$ & 3 & Al32 & $06 / 02 / 46$ & 0 & 1 \\
\hline Al06 & $07 / 29 / 45$ & 0 & Al32 & $06 / 30 / 46$ & 4 & 0 \\
\hline Al07 & $10 / 14 / 45$ & 3 & Al32 & $07 / 28 / 46$ & 0 & 6 \\
\hline A107 & $01 / 20 / 46$ & 0 & $\mathrm{Al} 33$ & $08 / 12 / 45$ & 0 & 0 \\
\hline AlOB & $03 / 24 / 46$ & 3 & Al34 & $12 / 16 / 45$ & 0 & 8 \\
\hline Al09 & $07 / 08 / 45$ & 2 & $\mathrm{Al} 34$ & $03 / 10 / 46$ & 0 & 3 \\
\hline Al09 & $08 / 26 / 45$ & 7 & Al 35 & $07 / 07 / 46$ & 0 & 2 \\
\hline Allo & $07 / 08 / 45$ & 0 & $\mathrm{Al} 36$ & $02 / 17 / 46$ & 0 & 0 \\
\hline AI 10 & $10 / 07 / 45$ & 0 & Al36 & $04 / 14 / 46$ & 0 & 0 \\
\hline All1 & $08 / 12 / 45$ & 32 & A137 & $06 / 09 / 46$ & 0 & 0 \\
\hline $\mathrm{Al} 12$ & $07 / 01 / 45$ & 5 & $A 138$ & $08 / 05 / 45$ & 0 & 0 \\
\hline Al13 & $07 / 08 / 45$ & 0 & $\mathrm{Al} 38$ & $10 / 14 / 45$ & 0 & 0 \\
\hline Al13 & $09 / 02 / 45$ & 0 & A139 & $10 / 07 / 45$ & 8 & 0 \\
\hline Al14 & $05 / 27 / 45$ & 7 & $\mathrm{Al} 40$ & $12 / 09 / 45$ & 4 & 4 \\
\hline Al15 & $08 / 05 / 45$ & 0 & A1 40 & $02 / 03 / 46$ & 2 & 0 \\
\hline Al15 & $11 / 11 / 45$ & 3 & AI 40 & $05 / 12 / 46$ & 0 & 0 \\
\hline Al 16 & $04 / 07 / 46$ & 6 & Al 40 & $05 / 26 / 46$ & 6 & 0 \\
\hline & $08 / 05 / 45$ & 0 & Al4l & $07 / 21 / 46$ & 0 & 0 \\
\hline All & $08 / 05 / 45$ & 0 & Al42 & $08 / 12 / 45$ & 4 & 4 \\
\hline Allg & $11 / 11 / 45$ & 0 & Al42 & $09 / 30 / 45$ & 39 & 7 \\
\hline Allo & $09 / 02 / 45$ & 0 & A142 & $11 / 25 / 45$ & 0 & 0 \\
\hline Al19 & $11 / 18 / 45$ & 0 & $\mathrm{Al} 43$ & $01 / 06 / 46$ & 5 & 10 \\
\hline $\mathrm{Al} 20$ & $01 / 20 / 46$ & 0 & $\mathrm{Al} 44$ & $07 / 29 / 45$ & 8 & 4 \\
\hline Al21 & $08 / 12 / 45$ & 8 & Al 44 & $09 / 16 / 45$ & 3 & 0 \\
\hline$A 121$ & $11 / 11 / 45$ & 0 & Al 44 & $11 / 11 / 45$ & 0 & 0 \\
\hline Al2 & $01 / 20 / 46$ & 9 & Al 45 & $11 / 11 / 45$ & 0 & 3 \\
\hline
\end{tabular}


TABLE A.1. (contd)

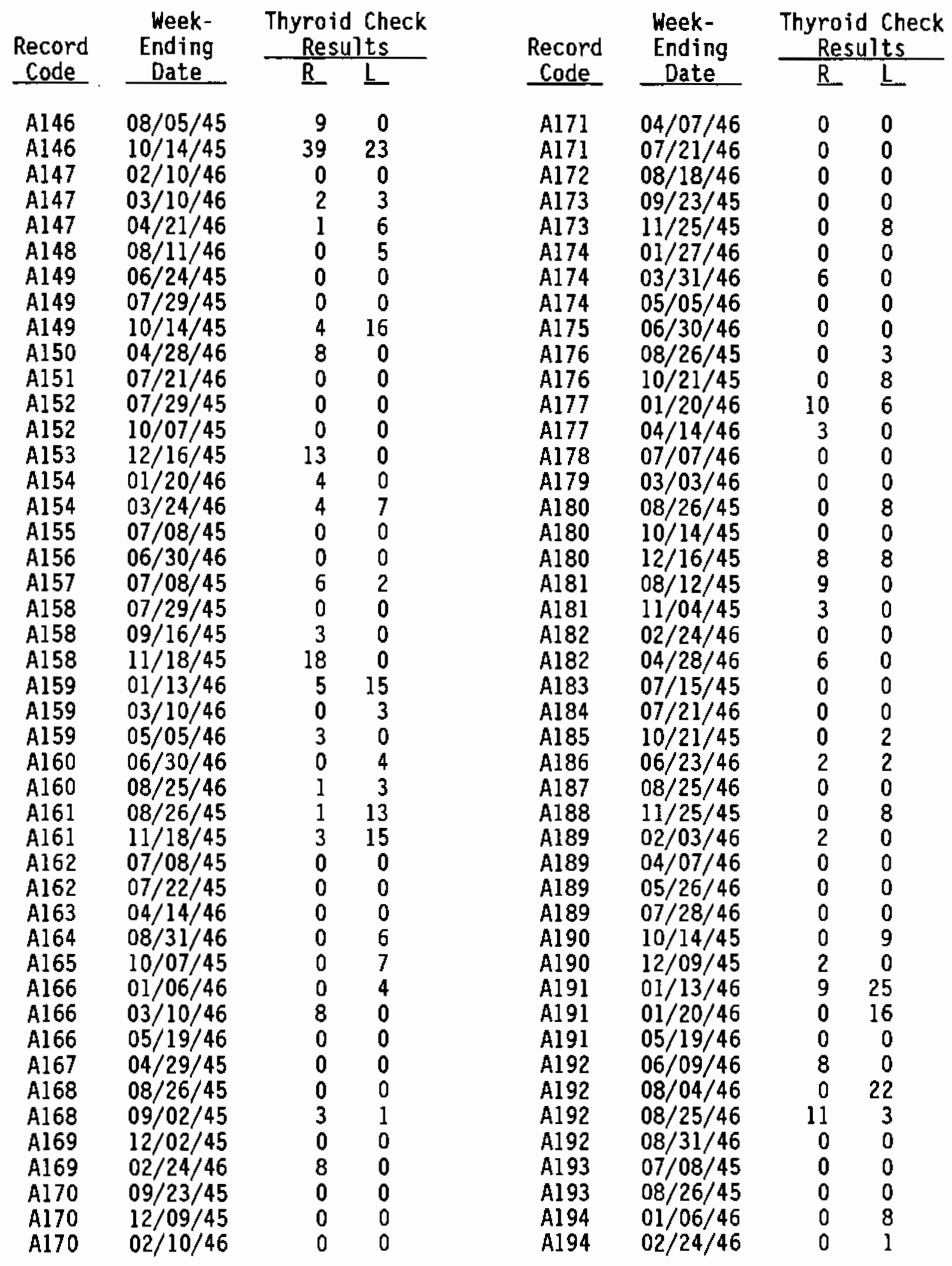


IABLE A.1. (contd)

\begin{tabular}{|c|c|c|c|c|c|c|c|}
\hline \multirow{2}{*}{$\begin{array}{l}\text { Record } \\
\text { Code } \\
\end{array}$} & $\begin{array}{l}\text { Week- } \\
\text { Ending }\end{array}$ & \multicolumn{2}{|c|}{$\begin{array}{c}\text { Thyroid Check } \\
\text { Results }\end{array}$} & \multirow{2}{*}{$\begin{array}{l}\text { Record } \\
\text { Code } \\
\end{array}$} & \multirow{2}{*}{$\begin{array}{l}\text { Week- } \\
\text { Ending } \\
\text { Date } \\
\end{array}$} & \multicolumn{2}{|c|}{$\begin{array}{c}\text { Thyroid Check } \\
\text { Results } \\
\end{array}$} \\
\hline & Date & $\underline{\mathrm{R}}$ & $L$ & & & $\mathrm{R}$ & $\underline{L}$ \\
\hline A194 & $04 / 28 / 46$ & 0 & 0 & A218 & $08 / 26 / 45$ & 0 & 3 \\
\hline A195 & $06 / 30 / 46$ & 0 & 0 & A219 & $11 / 19 / 44$ & 15 & 0 \\
\hline A196 & $07 / 29 / 45$ & 12 & 0 & A219 & $02 / 11 / 45$ & 3 & 0 \\
\hline A196 & $09 / 09 / 45$ & 0 & 0 & A220 & $07 / 22 / 45$ & 7 & 7 \\
\hline Al97 & $12 / 23 / 45$ & 0 & 3 & A220 & $10 / 28 / 45$ & 0 & 0 \\
\hline A197 & $03 / 03 / 46$ & 4 & 0 & A221 & $01 / 06 / 46$ & 0 & 1 \\
\hline Al97 & $05 / 26 / 46$ & 0 & 0 & A221 & $03 / 31 / 46$ & 0 & 0 \\
\hline A198 & $06 / 16 / 46$ & 7 & 0 & A222 & $06 / 02 / 46$ & 1 & 2 \\
\hline A198 & $06 / 23 / 46$ & 0 & 0 & A222 & $08 / 04 / 46$ & 0 & 0 \\
\hline Al98 & $09 / 01 / 46$ & 5 & 2 & A223 & $06 / 24 / 45$ & 0 & 0 \\
\hline Al9g & $07 / 15 / 45$ & 0 & 0 & A223 & $09 / 02 / 45$ & 0 & 10 \\
\hline A199 & $09 / 09 / 45$ & 0 & 0 & A223 & $11 / 04 / 45$ & 11 & 3 \\
\hline Al 99 & $11 / 18 / 45$ & 0 & 0 & A224 & $01 / 06 / 46$ & 0 & 0 \\
\hline A200 & $01 / 20 / 46$ & 6 & 0 & A224 & $03 / 03 / 46$ & 0 & 0 \\
\hline A200 & $03 / 17 / 46$ & 5 & 4 & A225 & $06 / 02 / 46$ & 0 & 9 \\
\hline A201 & $08 / 31 / 46$ & 0 & 0 & A225 & $07 / 28 / 46$ & 0 & 0 \\
\hline A202 & $06 / 17 / 45$ & 12 & 8 & A226 & $08 / 12 / 45$ & 0 & 16 \\
\hline A202 & $09 / 23 / 45$ & 0 & 14 & A226 & $10 / 14 / 45$ & 31 & 19 \\
\hline A202 & $11 / 18 / 45$ & 7 & 6 & A227 & $02 / 10 / 46$ & 0 & 0 \\
\hline A203 & $07 / 15 / 45$ & 26 & 0 & A227 & $04 / 14 / 46$ & 0 & 1 \\
\hline A203 & $09 / 02 / 45$ & 4 & 16 & A228 & $06 / 16 / 46$ & 2 & 3 \\
\hline A203 & $10 / 28 / 45$ & 0 & 0 & A228 & $08 / 25 / 46$ & 0 & 0 \\
\hline A204 & $12 / 23 / 45$ & 3 & 11 & A229 & $10 / 28 / 45$ & 0 & 0 \\
\hline A204 & $03 / 03 / 46$ & 0 & 0 & A230 & $07 / 14 / 46$ & 0 & 0 \\
\hline A204 & $05 / 19 / 46$ & 0 & 0 & A231 & $06 / 30 / 46$ & 0 & 0 \\
\hline A205 & $07 / 28 / 46$ & 0 & 0 & A232 & $07 / 15 / 45$ & 0 & 0 \\
\hline A206 & $07 / 08 / 45$ & 0 & 0 & A232 & $08 / 26 / 45$ & 0 & 3 \\
\hline A206 & $09 / 16 / 45$ & 4 & 0 & A233 & $11 / 11 / 45$ & 35 & 25 \\
\hline A207 & $07 / 15 / 45$ & 0 & 0 & A233 & $12 / 09 / 45$ & 3 & 0 \\
\hline A207 & $09 / 09 / 45$ & 0 & 0 & A233 & $01 / 06 / 46$ & 28 & 36 \\
\hline A207 & $11 / 11 / 45$ & 16 & 0 & A233 & $02 / 03 / 46$ & 0 & 8 \\
\hline A208 & $01 / 13 / 46$ & 5 & 0 & A233 & $03 / 03 / 46$ & 0 & 0 \\
\hline A209 & $08 / 11 / 46$ & 0 & 0 & A233 & $03 / 10 / 46$ & 0 & 0 \\
\hline A210 & $07 / 15 / 45$ & 10 & 0 & A233 & $03 / 31 / 46$ & 0 & 3 \\
\hline A211 & $12 / 02 / 45$ & 0 & 0 & A233 & $05 / 05 / 46$ & 0 & 0 \\
\hline A211 & $03 / 03 / 46$ & 0 & 0 & A234 & $06 / 02 / 46$ & 0 & 0 \\
\hline A212 & $06 / 02 / 46$ & 9 & 0 & A234 & $07 / 28 / 46$ & 0 & 0 \\
\hline A213 & $08 / 12 / 45$ & 17 & 1 & A234 & $08 / 25 / 46$ & 1 & 0 \\
\hline A213 & $10 / 14 / 45$ & 16 & 4 & A235 & $07 / 29 / 45$ & 0 & 0 \\
\hline A214 & $12 / 16 / 45$ & 0 & 4 & A235 & $10 / 14 / 45$ & 0 & 0 \\
\hline A214 & $04 / 14 / 46$ & 1 & 5 & A235 & $11 / 11 / 45$ & 10 & 2 \\
\hline A215 & $07 / 15 / 45$ & 4 & 12 & A236 & $02 / 24 / 46$ & 0 & 0 \\
\hline A215 & $10 / 28 / 45$ & 2 & 6 & A237 & $03 / 03 / 46$ & 0 & 0 \\
\hline A216 & $12 / 23 / 45$ & 9 & 0 & A237 & $03 / 17 / 46$ & 7 & 3 \\
\hline A217 & $07 / 07 / 46$ & 0 & 0 & A238 & $07 / 01 / 45$ & 0 & 0 \\
\hline
\end{tabular}


TABLE A. 1. (contd)

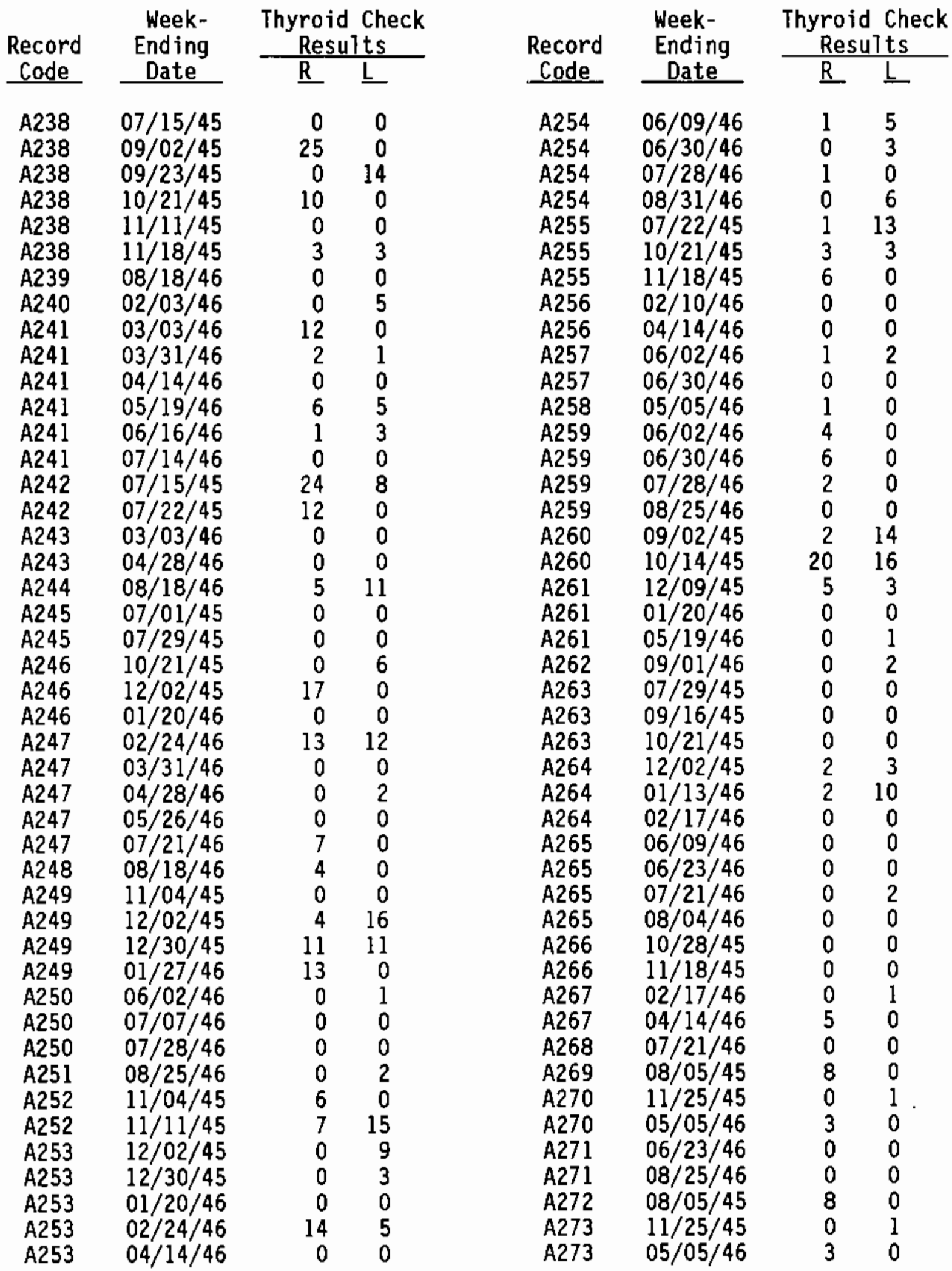


TABLE A.1. (contd)

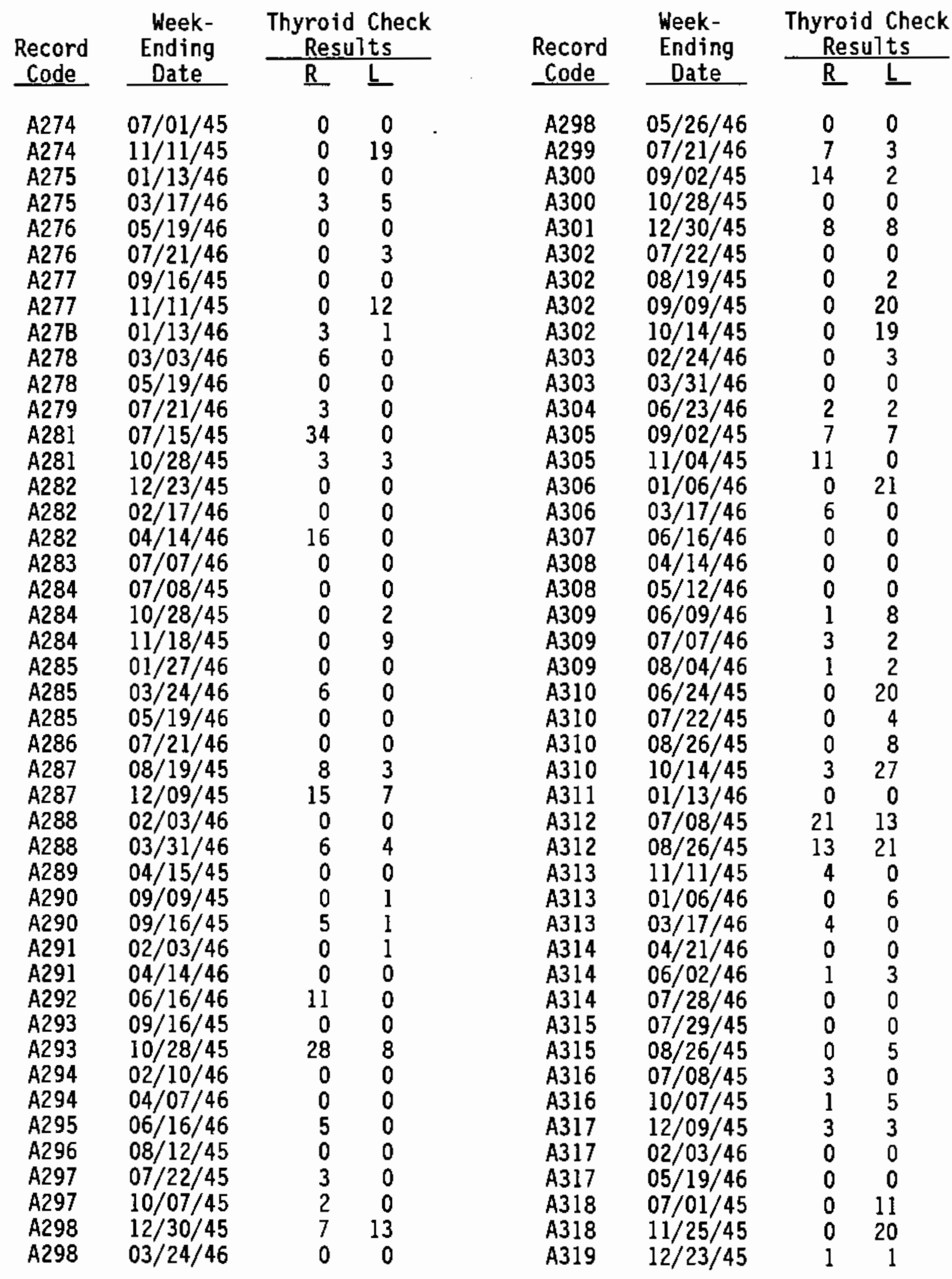


TABLE A.1. (contd)

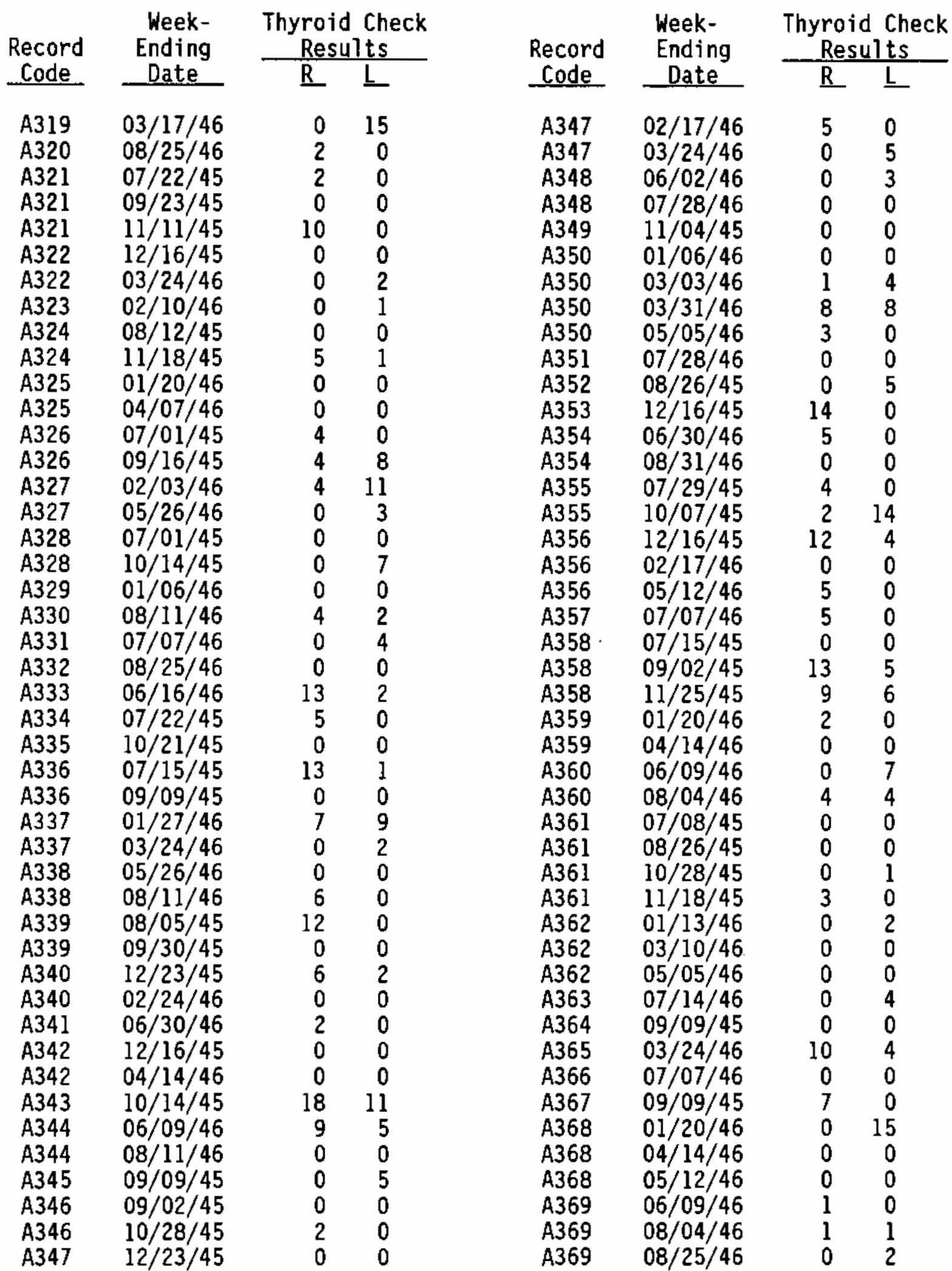


TABLE A.1. (contd)

\begin{tabular}{|c|c|c|c|c|c|c|c|}
\hline \multirow{2}{*}{$\begin{array}{l}\text { Record } \\
\text { Code }\end{array}$} & $\begin{array}{l}\text { Week- } \\
\text { Ending }\end{array}$ & \multicolumn{2}{|c|}{$\begin{array}{l}\text { Thyroid Check } \\
\text { Results } \\
\end{array}$} & \multirow{2}{*}{$\begin{array}{l}\text { Record } \\
\text { Code } \\
\end{array}$} & \multirow{2}{*}{$\begin{array}{l}\text { Week- } \\
\text { Ending } \\
\text { Date } \\
\end{array}$} & \multicolumn{2}{|c|}{$\begin{array}{c}\text { Thyroid Check } \\
\text { Results }\end{array}$} \\
\hline & & $\underline{R}$ & $\underline{\underline{L}}$ & & & $\underline{R}$ & $\underline{L}$ \\
\hline A370 & $07 / 15 / 45$ & 8 & 0 & A39l & $03 / 24 / 46$ & 0 & 11 \\
\hline A370 & $10 / 07 / 45$ & 3 & 0 & A392 & $05 / 26 / 46$ & 0 & 0 \\
\hline A371 & $02 / 10 / 46$ & 0 & 0 & A393 & $07 / 01 / 45$ & 0 & 0 \\
\hline A371 & $03 / 10 / 46$ & 0 & 2 & A393 & $08 / 19 / 45$ & 11 & 0 \\
\hline A372 & $05 / 26 / 46$ & 0 & 0 & A393 & $10 / 14 / 45$ & 0 & 16 \\
\hline A372 & $07 / 21 / 46$ & 0 & 2 & A394 & $03 / 17 / 46$ & 2 & 0 \\
\hline A373 & $06 / 17 / 45$ & 0 & 8 & A395 & $08 / 31 / 46$ & 6 & 3 \\
\hline A373 & $09 / 16 / 45$ & 16 & 40 & A396 & $08 / 12 / 45$ & 12 & 8 \\
\hline A374 & $11 / 18 / 45$ & 3 & 10 & A396 & $09 / 23 / 45$ & 0 & 19 \\
\hline A375 & $07 / 01 / 45$ & 1 & 5 & A396 & $11 / 18 / 45$ & 0 & 0 \\
\hline A375 & $07 / 29 / 45$ & 0 & 0 & A397 & $01 / 13 / 46$ & 2 & 3 \\
\hline A375 & $09 / 16 / 45$ & 12 & 8 & A397 & $03 / 10 / 46$ & 2 & 2 \\
\hline A375 & $11 / 11 / 45$ & 4 & 16 & A397 & $04 / 28 / 46$ & 2 & 1 \\
\hline A376 & $02 / 03 / 46$ & 9 & 1 & A398 & $06 / 30 / 46$ & 2 & 0 \\
\hline A376 & $04 / 28 / 46$ & 0 & 0 & A398 & $07 / 28 / 46$ & 2 & 0 \\
\hline A377 & $07 / 21 / 46$ & 0 & 0 & A399 & $11 / 11 / 45$ & 4 & 0 \\
\hline A378 & $07 / 29 / 45$ & 0 & 0 & A400 & $01 / 20 / 46$ & 0 & 0 \\
\hline A378 & $09 / 16 / 45$ & 0 & 0 & A400 & $03 / 31 / 46$ & 0 & 0 \\
\hline A379 & $12 / 02 / 45$ & 1 & 5 & A401 & $07 / 29 / 45$ & 0 & 22 \\
\hline A379 & $12 / 23 / 45$ & 0 & 0 & A401 & $10 / 21 / 45$ & 0 & 4 \\
\hline A379 & $03 / 24 / 46$ & 0 & 0 & A402 & $12 / 09 / 45$ & 4 & 3 \\
\hline A380 & $07 / 07 / 46$ & 3 & 0 & A402 & $03 / 31 / 46$ & 0 & 0 \\
\hline A380 & $08 / 31 / 46$ & 3 & 1 & A402 & $05 / 26 / 46$ & 0 & 0 \\
\hline A381 & $06 / 24 / 45$ & 0 & 7 & A403 & $08 / 04 / 46$ & 0 & 3 \\
\hline A381 & $10 / 14 / 45$ & 0 & 8 & A404 & $07 / 01 / 45$ & 0 & 0 \\
\hline A382 & $12 / 09 / 45$ & 29 & 0 & A405 & $09 / 16 / 45$ & 22 & 0 \\
\hline A382 & $02 / 10 / 46$ & 5 & 0 & A405 & $12 / 09 / 45$ & 15 & 27 \\
\hline A383 & $06 / 23 / 46$ & 0 & 0 & A405 & $02 / 24 / 46$ & 0 & 0 \\
\hline A383 & $08 / 25 / 46$ & 0 & 0 & A406 & $05 / 26 / 46$ & 0 & 3 \\
\hline A384 & $08 / 25 / 46$ & 7 & 7 & A406 & $07 / 28 / 46$ & 4 & 0 \\
\hline A384 & $08 / 31 / 46$ & 0 & 7 & A407 & $07 / 15 / 45$ & 0 & 3 \\
\hline A384 & $08 / 31 / 46$ & 19 & 7 & A407 & $10 / 21 / 45$ & 2 & 0 \\
\hline A385 & $05 / 05 / 46$ & 0 & 0 & A408 & $12 / 23 / 45$ & 0 & 2 \\
\hline A386 & $08 / 31 / 46$ & 0 & 3 & A408 & $04 / 07 / 46$ & 0 & 0 \\
\hline A387 & $07 / 08 / 45$ & 0 & 0 & A409 & $08 / 18 / 46$ & 0 & 0 \\
\hline A387 & $08 / 19 / 45$ & 0 & 0 & A410 & $07 / 01 / 45$ & 0 & 3 \\
\hline A387. & $09 / 23 / 45$ & 12 & 0 & A410 & $10 / 07 / 45$ & 11 & II \\
\hline A387 & $11 / 11 / 45$ & 0 & 9 & A411 & $12 / 09 / 45$ & 5 & 3 \\
\hline A388 & $01 / 13 / 46$ & 26 & 6 & A411 & $02 / 10 / 46$ & 3 & 3 \\
\hline A388 & $03 / 10 / 46$ & 0 & 0 & A412 & $07 / 07 / 46$ & 0 & 0 \\
\hline A388 & $04 / 28 / 46$ & 0 & 0 & A413 & $11 / 11 / 45$ & 0 & 7 \\
\hline A389 & $06 / 30 / 46$ & 0 & 0 & A413 & $01 / 06 / 46$ & 4 & 0 \\
\hline A390 & $07 / 08 / 45$ & 0 & 0 & A413 & $03 / 03 / 46$ & 0 & 3 \\
\hline A391 & $11 / 25 / 45$ & 0 & 0 & A414 & $08 / 04 / 46$ & 9 & 0 \\
\hline A391 & $01 / 20 / 46$ & 3 & 8 & A415 & $11 / 04 / 45$ & 11 & 0 \\
\hline
\end{tabular}


IABLE A.1. (contd)

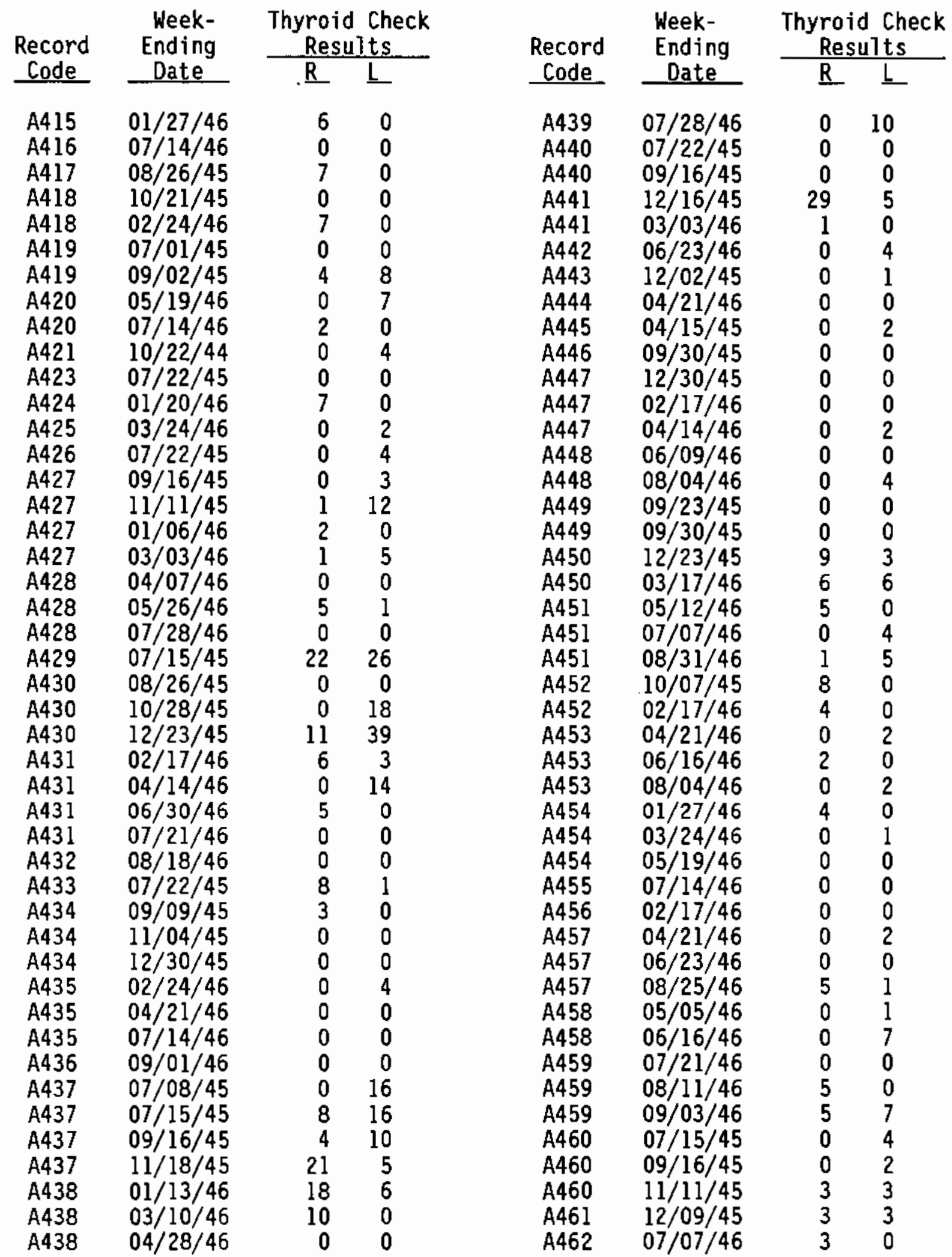


TABLE A.1. (contd)

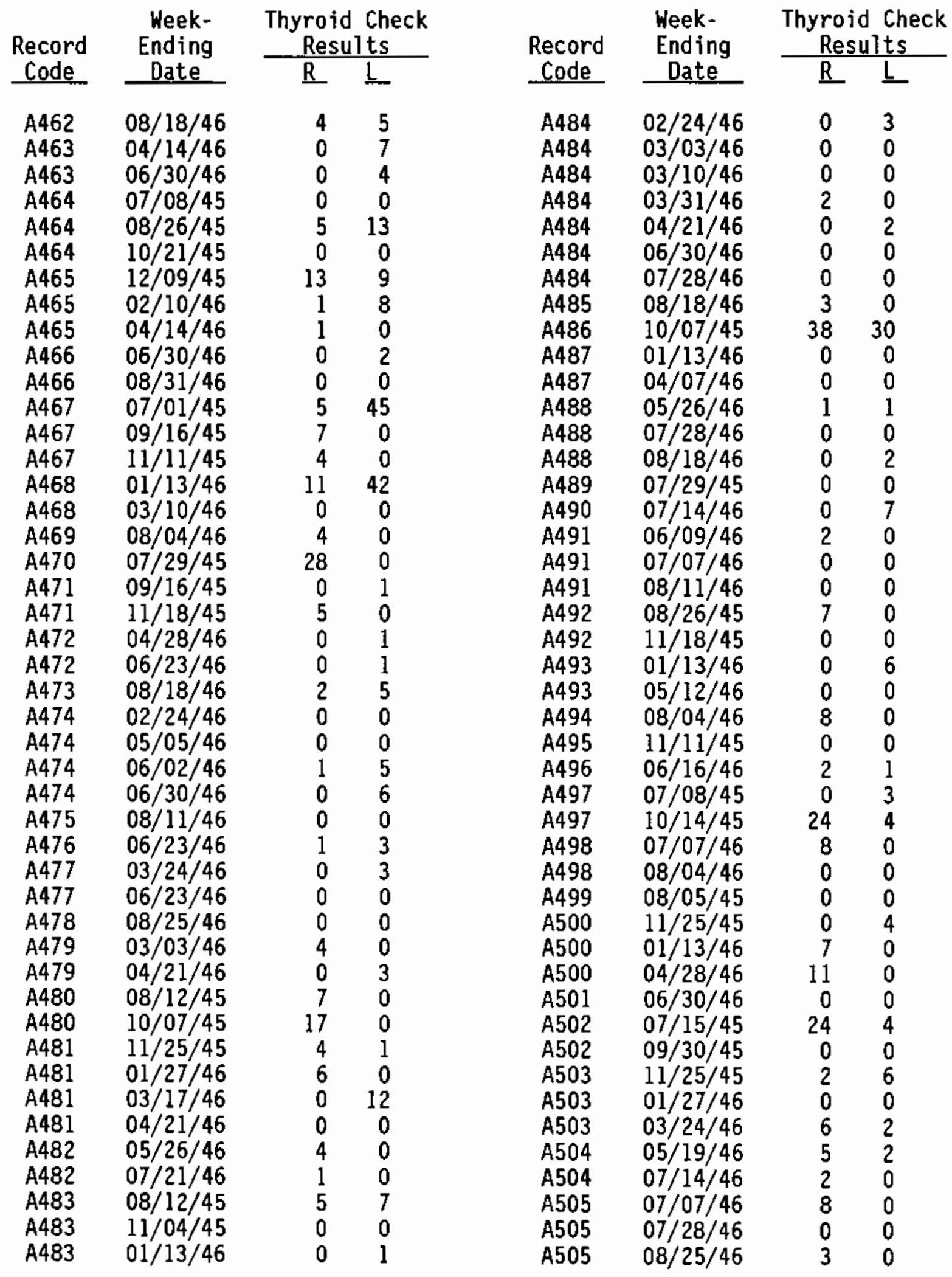


IABLE A.1. (contd)

\begin{tabular}{|c|c|c|c|c|c|c|c|}
\hline \multirow{2}{*}{$\begin{array}{c}\text { Record } \\
\text { Code }\end{array}$} & \multirow{2}{*}{$\begin{array}{l}\text { Week- } \\
\text { Ending } \\
\text { Date }\end{array}$} & \multicolumn{2}{|c|}{$\begin{array}{c}\text { Thyroid Check } \\
\text { Results } \\
\end{array}$} & \multirow{2}{*}{$\begin{array}{l}\text { Record } \\
\text { Code } \\
\end{array}$} & \multirow{2}{*}{$\begin{array}{l}\text { Week- } \\
\text { Ending } \\
\text { Date }\end{array}$} & \multicolumn{2}{|c|}{$\begin{array}{l}\text { Thyroid Check } \\
\text { Results } \\
\end{array}$} \\
\hline & & $\underline{\mathrm{R}}$ & $\underline{L}$ & & & $\underline{R}$ & $\underline{L}$ \\
\hline A506 & $07 / 14 / 46$ & 0 & 0 & A532 & $07 / 21 / 46$ & 4 & 0 \\
\hline A507 & $07 / 29 / 45$ & 0 & 12 & A533 & $10 / 21 / 45$ & 0 & 4 \\
\hline A508 & $09 / 23 / 45$ & 0 & 0 & A533 & $12 / 16 / 45$ & 0 & 6 \\
\hline A508 & $11 / 11 / 45$ & 0 & 0 & A533 & $02 / 17 / 46$ & 8 & 0 \\
\hline A508 & $01 / 13 / 46$ & 0 & 4 & A534 & $03 / 17 / 46$ & 1 & 1 \\
\hline A509 & $06 / 16 / 46$ & 0 & 0 & A534 & $04 / 21 / 46$ & 0 & 0 \\
\hline A509 & $07 / 21 / 46$ & 0 & 0 & A534 & $06 / 16 / 46$ & 0 & 0 \\
\hline A509 & $08 / 18 / 46$ & 0 & 0 & A534 & $08 / 18 / 46$ & 0 & 0 \\
\hline A510 & $12 / 09 / 45$ & 0 & 11 & A535 & $07 / 01 / 45$ & 0 & 0 \\
\hline A511 & $03 / 10 / 46$ & 0 & 0 & A536 & $07 / 15 / 45$ & 0 & 0 \\
\hline A512 & $09 / 09 / 45$ & 4 & 0 & A536 & $09 / 02 / 45$ & 5 & 0 \\
\hline A513 & $12 / 09 / 45$ & 4 & 0 & A537 & $06 / 24 / 45$ & 0 & 13 \\
\hline A513 & $02 / 10 / 46$ & 0 & 1 & A538 & $07 / 29 / 45$ & 0 & 0 \\
\hline A513 & $03 / 03 / 46$ & 4 & 0 & A539 & $12 / 09 / 45$ & 4 & 3 \\
\hline A513 & $03 / 31 / 46$ & 3 & 2 & A539 & $03 / 31 / 46$ & 9 & 3 \\
\hline A514 & $06 / 30 / 46$ & 2 & 0 & A540 & $07 / 14 / 46$ & 0 & 4 \\
\hline A514 & $09 / 01 / 46$ & 0 & 0 & A540 & $08 / 31 / 46$ & 0 & 1 \\
\hline A515 & $02 / 24 / 46$ & 0 & 0 & A541 & $12 / 24 / 44$ & 0 & 0 \\
\hline A516 & $03 / 17 / 46$ & 7 & 0 & A542 & $08 / 05 / 45$ & 8 & 0 \\
\hline A516 & $03 / 31 / 46$ & 10 & 1 & A542 & $09 / 23 / 45$ & 8 & 3 \\
\hline A516 & $07 / 14 / 46$ & 0 & 0 & A543 & $07 / 15 / 45$ & 12 & 0 \\
\hline A517 & $08 / 26 / 45$ & 1 & 0 & A543 & $09 / 23 / 45$ & 0 & 7 \\
\hline A518 & $09 / 23 / 45$ & 0 & 0 & A544 & $01 / 06 / 46$ & 0 & 5 \\
\hline A518 & $11 / 25 / 45$ & 6 & 8 & A544 & $03 / 10 / 46$ & 0 & 2 \\
\hline A518 & $01 / 20 / 46$ & 5 & 1 & A544 & $05 / 26 / 46$ & 0 & 0 \\
\hline A519 & $06 / 09 / 46$ & 0 & 0 & A545 & $07 / 21 / 46$ & 1 & 0 \\
\hline A520 & $11 / 11 / 45$ & 0 & 3 & A546 & $07 / 08 / 45$ & 0 & 0 \\
\hline A520 & $01 / 13 / 46$ & 2 & 0 & A546 & $09 / 16 / 45$ & 18 & 10 \\
\hline A520 & $03 / 03 / 46$ & 0 & 0 & A546 & $11 / 11 / 45$ & 0 & 4 \\
\hline A521 & $05 / 05 / 46$ & 0 & 0 & A547 & $01 / 06 / 46$ & 0 & 0 \\
\hline A521 & $07 / 21 / 46$ & 0 & 0 & A547 & $02 / 24 / 46$ & 0 & 0 \\
\hline A522 & $09 / 16 / 45$ & 1 & 0 & A548 & $06 / 23 / 46$ & 0 & 0 \\
\hline A522 & $09 / 23 / 45$ & 0 & 0 & A548 & $08 / 18 / 46$ & 0 & 3 \\
\hline A523 & $07 / 15 / 45$ & 0 & 14 & A549 & $10 / 21 / 45$ & 0 & 0 \\
\hline A524 & $07 / 22 / 45$ & 0 & 0 & A549 & $10 / 28 / 45$ & 0 & 0 \\
\hline A525 & $09 / 09 / 45$ & 5 & 17 & A549 & $11 / 04 / 45$ & 3 & 11 \\
\hline A525 & $11 / 04 / 45$ & 3 & 7 & A549 & $01 / 13 / 46$ & 13 & 11 \\
\hline A525 & $12 / 23 / 45$ & 0 & 0 & A549 & $03 / 10 / 46$ & 0 & 2 \\
\hline A526 & $04 / 07 / 46$ & 3 & 2 & A550 & $05 / 05 / 46$ & 0 & 0 \\
\hline A527 & $10 / 14 / 45$ & 0 & 5 & A550 & $07 / 28 / 46$ & 0 & 0 \\
\hline A528 & $07 / 21 / 46$ & 0 & 0 & A552 & $07 / 08 / 45$ & 0 & 0 \\
\hline A529 & $04 / 21 / 46$ & 0 & 0 & A552 & $08 / 26 / 45$ & 0 & 0 \\
\hline A529 & $07 / 28 / 46$ & 1 & 1 & A553 & $10 / 21 / 45$ & 0 & 0 \\
\hline A530 & $09 / 02 / 45$ & 22 & 18 & A553 & $12 / 23 / 45$ & 5 & 0 \\
\hline A531 & $04 / 21 / 46$ & 0 & 0 & A553 & $02 / 24 / 46$ & 0 & 0 \\
\hline
\end{tabular}


TABLE_A.1. (contd)

\begin{tabular}{|c|c|c|c|c|c|c|c|}
\hline \multirow{2}{*}{$\begin{array}{c}\text { Record } \\
\text { Code } \\
\end{array}$} & \multirow{2}{*}{$\begin{array}{c}\text { Week- } \\
\text { Ending } \\
\text { Date } \\
\end{array}$} & \multicolumn{2}{|c|}{ Thyroid Check } & \multirow{2}{*}{$\begin{array}{l}\text { Record } \\
\text { Code } \\
\end{array}$} & \multirow{2}{*}{$\begin{array}{c}\text { Week- } \\
\text { Ending } \\
\text { Date } \\
\end{array}$} & \multicolumn{2}{|c|}{$\begin{array}{l}\text { Thyroid Check } \\
\text { Results } \\
\end{array}$} \\
\hline & & $\underline{R}$ & $\underline{L}$ & & & $\underline{R}$ & $\underline{L}$ \\
\hline A554 & $04 / 28 / 46$ & 0 & 0 & A576 & $07 / 29 / 45$ & 0 & 0 \\
\hline A554 & $06 / 23 / 46$ & 4 & 5 & A576 & $08 / 26 / 45$ & 0 & 7 \\
\hline A555 & $09 / 23 / 45$ & 0 & 0 & A576 & $09 / 30 / 45$ & 4 & 12 \\
\hline A556 & $07 / 21 / 46$ & 0 & 0 & A577 & $09 / 09 / 45$ & 0 & 0 \\
\hline A557 & $07 / 15 / 45$ & 0 & 2 & A578 & $11 / 04 / 45$ & 0 & 0 \\
\hline A557 & $08 / 26 / 45$ & 0 & 0 & A578 & $12 / 30 / 45$ & 0 & 0 \\
\hline A557 & $09 / 23 / 45$ & 7 & 0 & A578 & $02 / 24 / 46$ & 0 & 2 \\
\hline A558 & $06 / 24 / 45$ & 17 & 17 & A579 & $09 / 02 / 45$ & 13 & 9 \\
\hline A559 & $12 / 23 / 45$ & 4 & 0 & A579 & $11 / 18 / 45$ & 15 & 0 \\
\hline A559 & $02 / 17 / 46$ & 4 & 0 & A580 & $01 / 13 / 46$ & 2 & 4 \\
\hline A559 & $03 / 31 / 46$ & 2 & 0 & A580 & $03 / 10 / 46$ & 0 & 0 \\
\hline A560 & $04 / 21 / 46$ & 3 & 5 & A580 & $05 / 26 / 46$ & 2 & 2 \\
\hline A560 & $06 / 30 / 46$ & 6 & 1 & A581 & $06 / 23 / 46$ & 6 & 0 \\
\hline A561 & $02 / 24 / 46$ & 0 & 2 & A582 & $10 / 28 / 45$ & 0 & 0 \\
\hline A562 & $04 / 28 / 46$ & 9 & 0 & A582 & $11 / 11 / 45$ & 0 & 11 \\
\hline A562 & $05 / 19 / 46$ & 3 & 0 & A583 & $01 / 13 / 46$ & 16 & 18 \\
\hline A563 & $12 / 09 / 45$ & 9 & 9 & A583 & $03 / 10 / 46$ & 0 & 7 \\
\hline A563 & $02 / 24 / 46$ & 0 & 1 & A583 & $04 / 28 / 46$ & 0 & 3 \\
\hline A564 & $06 / 09 / 46$ & 0 & 0 & A584 & $07 / 21 / 46$ & 0 & 0 \\
\hline A565 & $07 / 29 / 45$ & 0 & 0 & A585 & $07 / 15 / 45$ & 22 & 22 \\
\hline A565 & $08 / 26 / 45$ & 7 & 7 & A585 & $09 / 02 / 45$ & 0 & 17 \\
\hline A565 & $10 / 14 / 45$ & 7 & 0 & A586 & $10 / 28 / 45$ & 0 & 7 \\
\hline A565 & $12 / 09 / 45$ & 0 & 3 & A586 & $01 / 13 / 46$ & 30 & 0 \\
\hline A565 & $03 / 03 / 46$ & 0 & 0 & A586 & $01 / 27 / 46$ & 0 & 0 \\
\hline A565 & $04 / 28 / 46$ & 0 & 0 & A586 & $02 / 17 / 46$ & 0 & 0 \\
\hline A566 & $06 / 23 / 46$ & 4 & 11 & A587 & $06 / 09 / 46$ & 7 & 0 \\
\hline A566 & $08 / 18 / 46$ & I & 4 & A587 & $08 / 04 / 46$ & 0 & 6 \\
\hline A567 & $07 / 15 / 45$ & 12 & 0 & A588 & $08 / 05 / 45$ & 9 & 0 \\
\hline A567 & $08 / 26 / 45$ & 0 & 8 & A589 & $10 / 21 / 45$ & 4 & 0 \\
\hline A567 & $10 / 28 / 45$ & 19 & 35 & A589 & $03 / 10 / 46$ & 4 & 0 \\
\hline A568 & $12 / 23 / 45$ & 3 & 11 & A590 & $08 / 05 / 45$ & 14 & 10 \\
\hline A568 & $02 / 24 / 46$ & 2 & 0 & A590 & $09 / 02 / 45$ & 4 & 2 \\
\hline A568 & $05 / 12 / 46$ & 0 & 0 & A591 & $07 / 29 / 45$ & 0 & 0 \\
\hline A569 & $09 / 09 / 45$ & 11 & 7 & A591 & $09 / 16 / 45$ & 0 & 12 \\
\hline A570 & $11 / 18 / 45$ & 0 & 0 & A592 & $02 / 03 / 46$ & 5 & 2 \\
\hline A570 & $0 \mathrm{I} / 27 / 46$ & 2 & 8 & A592 & $04 / 07 / 46$ & 0 & 0 \\
\hline A570 & $03 / 31 / 46$ & 8 & 4 & A593 & $06 / 16 / 46$ & 12 & 4 \\
\hline & $03 / 03 / 46$ & 0 & 7 & A594 & $07 / 15 / 45$ & 18 & 2 \\
\hline A571 & $04 / 28 / 46$ & 6 & 2 & A595 & $07 / 01 / 45$ & 0 & 0 \\
\hline A571 & $06 / 23 / 46$ & 0 & 0 & A595 & $08 / 19 / 45$ & 0 & 0 \\
\hline A572 & $08 / 18 / 46$ & 2 & 0 & A596 & $11 / 04 / 45$ & 0 & 0 \\
\hline & $07 / 22 / 45$ & 12 & 4 & A596 & $01 / 27 / 46$ & 0 & 0 \\
\hline & $10 / 07 / 45$ & 34 & 30 & A596 & $03 / 24 / 46$ & 5 & 0 \\
\hline & $01 / 27 / 46$ & 0 & 3 & A597 & $08 / 11 / 46$ & 12 & 5 \\
\hline & $07 / 21 / 46$ & 5 & 0 & A598 & $07 / 15 / 45$ & 0 & 3 \\
\hline
\end{tabular}


IABLE A.1. (contd)

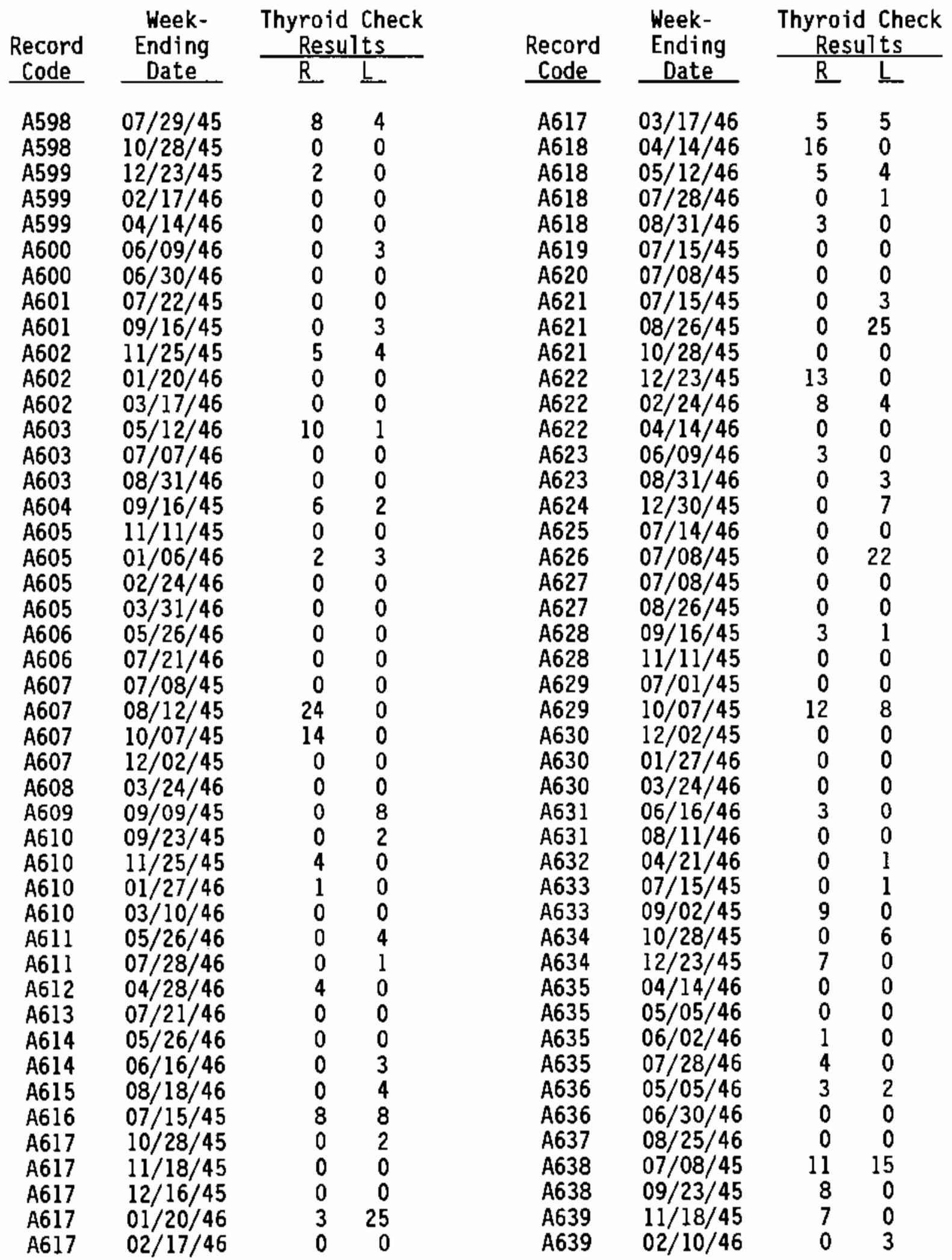


IABLE A.1. (contd)

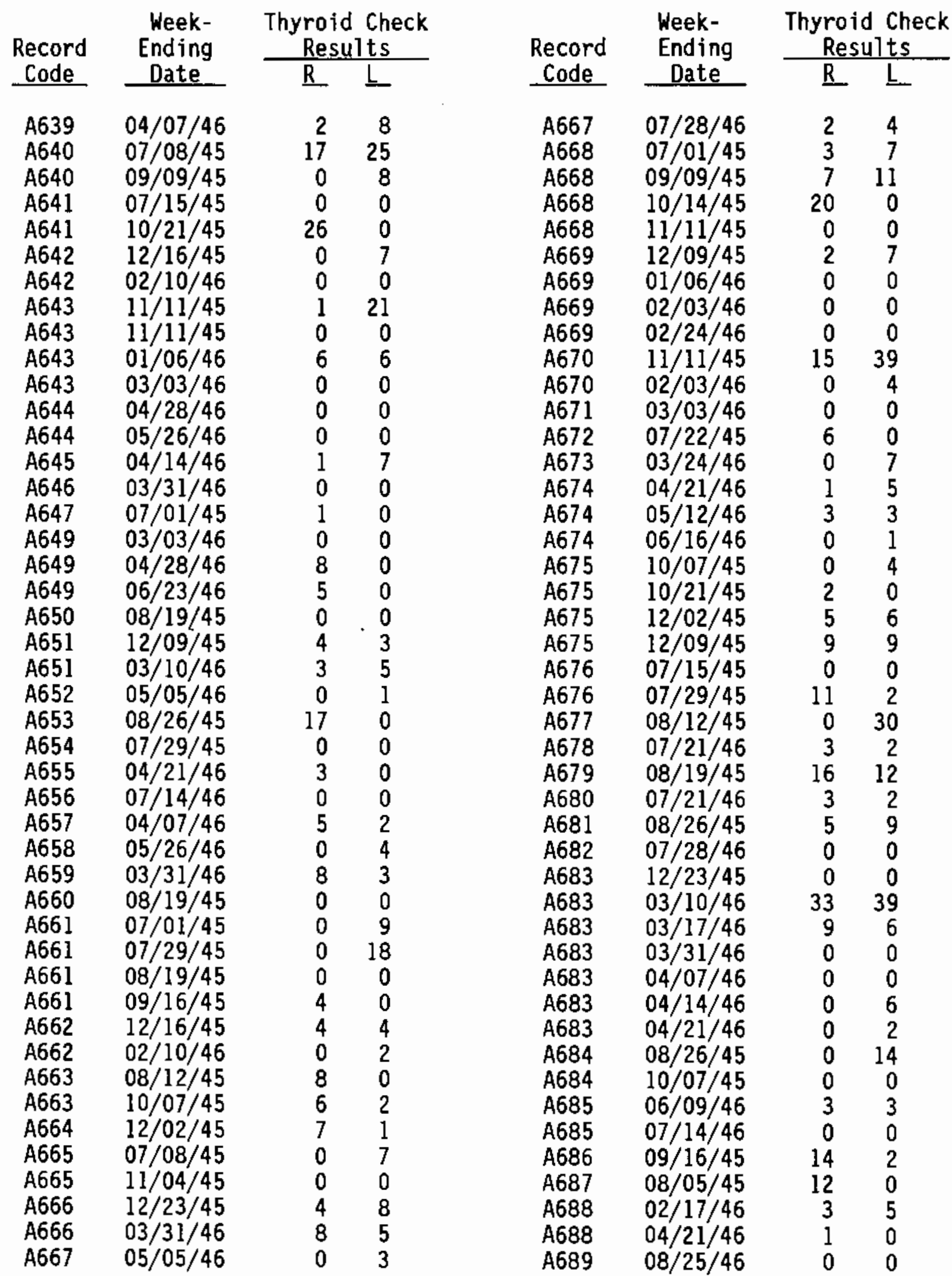


TABLE A.1. (contd)

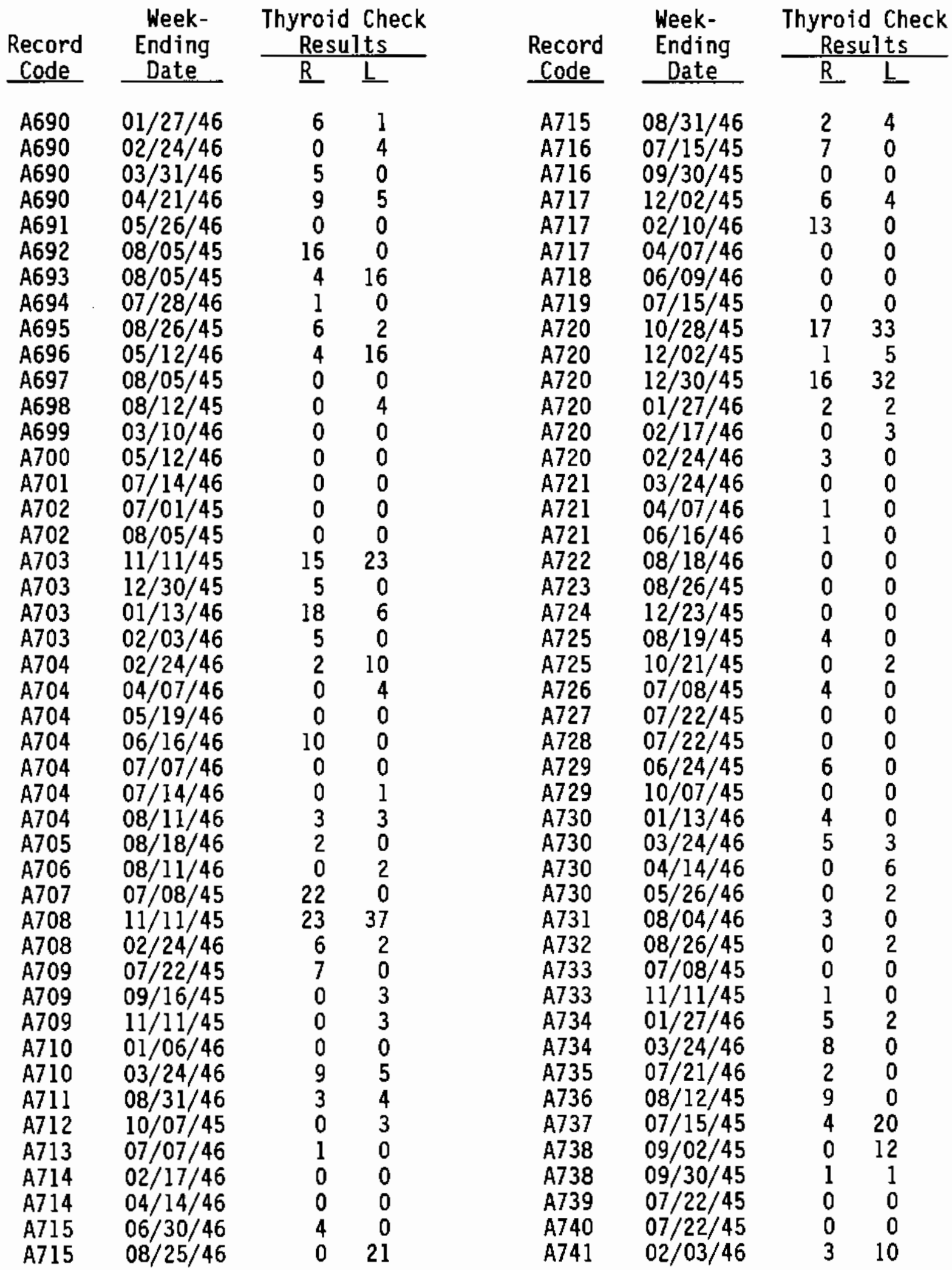


TABLE A.1. (contd)

\begin{tabular}{|c|c|c|c|c|c|c|c|}
\hline \multirow{2}{*}{$\begin{array}{l}\text { Record } \\
\text { Code } \\
\end{array}$} & \multirow{2}{*}{$\begin{array}{l}\text { Week- } \\
\text { Ending } \\
\text { Date }\end{array}$} & \multicolumn{2}{|c|}{$\begin{array}{c}\text { Thyroid Check } \\
\text { Results }\end{array}$} & \multirow{2}{*}{$\begin{array}{l}\text { Record } \\
\text { Code }\end{array}$} & \multirow{2}{*}{$\begin{array}{l}\text { Week- } \\
\text { Ending } \\
\text { Date } \\
\end{array}$} & \multicolumn{2}{|c|}{$\begin{array}{l}\text { Thyroid Check } \\
\text { Results } \\
\end{array}$} \\
\hline & & & $\underline{L}$ & & & & \\
\hline A741 & $04 / 07 / 46$ & 3 & 0 & A765 & $08 / 04 / 46$ & 6 & 0 \\
\hline A742 & $12 / 09 / 45$ & 5 & 2 & A766 & $10 / 14 / 45$ & 12 & B \\
\hline A742 & $03 / 31 / 46$ & 5 & 3 & A766 & $01 / 27 / 46$ & 1 & 0 \\
\hline A743 & $06 / 09 / 46$ & 0 & I & A767 & $08 / 04 / 46$ & 0 & 0 \\
\hline A743 & $08 / 18 / 46$ & 1 & 2 & A768 & $09 / 30 / 45$ & 0 & 0 \\
\hline A744 & $07 / 22 / 45$ & 13 & 0 & A768 & $02 / 17 / 46$ & 5 & 0 \\
\hline A745 & $08 / 05 / 45$ & 0 & 4 & A769 & $03 / 17 / 46$ & 0 & 1 \\
\hline A746 & $12 / 23 / 45$ & 1 & 0 & A769 & $05 / 12 / 46$ & 1 & 0 \\
\hline A746 & $02 / 24 / 46$ & 0 & 1 & A769 & $07 / 07 / 46$ & 0 & 0 \\
\hline A746 & $05 / 26 / 46$ & 1 & 0 & A770 & $11 / 11 / 45$ & 15 & 31 \\
\hline A747 & $07 / 15 / 45$ & 0 & 0 & A770 & $02 / 10 / 46$ & 5 & 0 \\
\hline A747 & $09 / 09 / 45$ & 0 & 4 & A771 & $07 / 15 / 45$ & 46 & 14 \\
\hline A747 & $11 / 11 / 45$ & 23 & 11 & A772 & $04 / 14 / 46$ & 0 & 7 \\
\hline A748 & $01 / 27 / 46$ & 24 & 24 & A772 & $06 / 23 / 46$ & 3 & 0 \\
\hline A748 & $03 / 03 / 46$ & 0 & 0 & A773 & $10 / 14 / 45$ & 19 & 11 \\
\hline A749 & $07 / 15 / 45$ & 3 & 31 & A773 & $01 / 06 / 46$ & 16 & 22 \\
\hline A749 & $09 / 16 / 45$ & 8 & 8 & A774 & $03 / 31 / 46$ & 0 & 1 \\
\hline A749 & $11 / 11 / 45$ & 7 & 31 & A774 & $07 / 21 / 46$ & 0 & 9 \\
\hline A750 & $04 / 07 / 46$ & 0 & 4 & A775 & $10 / 21 / 45$ & 0 & 0 \\
\hline A751 & $07 / 15 / 45$ & 1 & 5 & A775 & $01 / 20 / 46$ & 0 & 9 \\
\hline A751 & $09 / 09 / 45$ & 0 & 0 & A776 & $03 / 24 / 46$ & 0 & 0 \\
\hline A752 & $01 / 27 / 46$ & 0 & 0 & A776 & $07 / 28 / 46$ & 6 & 0 \\
\hline A752 & $03 / 03 / 46$ & 3 & 5 & A777 & $07 / 07 / 46$ & 0 & 0 \\
\hline A753 & $10 / 14 / 45$ & 12 & 8 & A778 & $10 / 21 / 45$ & 16 & 0 \\
\hline A753 & $01 / 27 / 46$ & 1 & 0 & A778 & $01 / 20 / 46$ & 0 & 0 \\
\hline A754 & $08 / 04 / 46$ & 0 & 0 & A779 & $03 / 24 / 46$ & 5 & 0 \\
\hline A755 & $01 / 06 / 46$ & 0 & 4 & A779 & $07 / 28 / 46$ & 0 & 6 \\
\hline A755 & $03 / 10 / 46$ & 0 & 6 & A779 & $08 / 25 / 46$ & 0 & 0 \\
\hline A756 & $06 / 30 / 46$ & 2 & 0 & A780 & $07 / 22 / 45$ & 0 & 0 \\
\hline A757 & $07 / 29 / 45$ & 13 & 1 & A781 & $10 / 21 / 45$ & 0 & 1 \\
\hline A758 & $09 / 16 / 45$ & 44 & 36 & A781 & $12 / 16 / 45$ & 15 & 0 \\
\hline A758 & $11 / 18 / 45$ & 21 & 21 & A781 & $02 / 10 / 46$ & 0 & 0 \\
\hline A758 & $01 / 13 / 46$ & 0 & 0 & A782 & $03 / 10 / 46$ & 0 & 0 \\
\hline A758 & $02 / 10 / 46$ & 0 & 7 & A782 & $04 / 07 / 46$ & 4 & 0 \\
\hline A759 & $04 / 28 / 46$ & 0 & 0 & A782 & $08 / 25 / 46$ & 0 & 9 \\
\hline A759 & $06 / 23 / 46$ & 0 & 0 & A783 & $10 / 21 / 45$ & 0 & 9 \\
\hline A760 & $07 / 22 / 45$ & 0 & 0 & A783 & $12 / 16 / 45$ & 2 & 22 \\
\hline A761 & $08 / 05 / 45$ & 12 & 12 & A783 & $02 / 03 / 46$ & 0 & 0 \\
\hline A762 & $12 / 02 / 45$ & 5 & 1 & A784 & $04 / 07 / 46$ & 8 & 3 \\
\hline A762 & $03 / 17 / 46$ & 0 & 3 & A784 & $06 / 02 / 46$ & 0 & 4 \\
\hline A763 & $07 / 14 / 46$ & 0 & 0 & A785 & $06 / 16 / 46$ & 0 & 5 \\
\hline A764 & $09 / 30 / 45$ & 0 & 13 & A785 & $07 / 21 / 46$ & 0 & 0 \\
\hline A764 & $11 / 25 / 45$ & 4 & 0 & A786 & $08 / 31 / 46$ & 0 & 3 \\
\hline A764 & $02 / 03 / 46$ & 0 & 0 & A787 & $07 / 15 / 45$ & 0 & 0 \\
\hline A765 & $03 / 31 / 46$ & 0 & 0 & A788 & $03 / 03 / 46$ & 3 & 0 \\
\hline
\end{tabular}


TABLE A.1. (contd)

\begin{tabular}{|c|c|c|c|c|c|c|c|}
\hline \multirow{2}{*}{$\begin{array}{l}\text { Record } \\
\text { Code } \\
\end{array}$} & \multirow{2}{*}{$\begin{array}{c}\text { Week- } \\
\text { Ending } \\
\text { Date }\end{array}$} & \multicolumn{2}{|c|}{$\begin{array}{l}\text { Thyroid Check } \\
\text { Results }\end{array}$} & \multirow{2}{*}{$\begin{array}{l}\text { Record } \\
\text { Code }\end{array}$} & \multirow{2}{*}{$\begin{array}{l}\text { Week- } \\
\text { Ending } \\
\text { Date }\end{array}$} & \multicolumn{2}{|c|}{$\begin{array}{l}\text { Thyroid Check } \\
\text { Results } \\
\end{array}$} \\
\hline & & $\underline{R}$ & $\underline{\underline{L}}$ & & & $\underline{R}$ & $L$ \\
\hline A789 & $05 / 05 / 46$ & 0 & 0 & A807 & $02 / 17 / 46$ & 0 & 0 \\
\hline A790 & $08 / 26 / 45$ & 23 & 11 & A807 & $04 / 14 / 46$ & 0 & 4 \\
\hline A791 & $10 / 14 / 45$ & 7 & 0 & A808 & $06 / 09 / 46$ & 0 & 0 \\
\hline A791 & $01 / 06 / 46$ & 0 & 0 & A808 & $08 / 04 / 46$ & 0 & 0 \\
\hline A79l & $03 / 03 / 46$ & 0 & 2 & A808 & $08 / 31 / 46$ & 0 & l \\
\hline A792 & $04 / 28 / 46$ & 0 & 6 & A809 & $09 / 09 / 45$ & 11 & 0 \\
\hline A792 & $06 / 23 / 46$ & 0 & 1 & A810 & $11 / 11 / 45$ & 4 & 0 \\
\hline A792 & $08 / 18 / 46$ & 3 & 0 & A810 & $01 / 27 / 46$ & 0 & 0 \\
\hline A793 & $09 / 23 / 45$ & 2 & 2 & A811 & $03 / 24 / 46$ & 1 & 2 \\
\hline A793 & $11 / 18 / 45$ & 1 & 0 & A811 & $05 / 19 / 46$ & 0 & 0 \\
\hline A793 & $02 / 17 / 46$ & 0 & 5 & A811 & $07 / 21 / 46$ & 0 & 0 \\
\hline A794 & $04 / 14 / 46$ & 4 & 0 & A812 & $07 / 22 / 45$ & 0 & 0 \\
\hline A794 & $06 / 09 / 46$ & 0 & 0 & A813 & $09 / 30 / 45$ & 0 & 18 \\
\hline A794 & $07 / 21 / 46$ & 0 & 0 & A813 & $12 / 09 / 45$ & 5 & 6 \\
\hline A795 & $07 / 15 / 45$ & 6 & l & A814 & $03 / 31 / 46$ & 3 & 3 \\
\hline A795 & $08 / 26 / 45$ & 3 & 0 & A814 & $07 / 14 / 46$ & 2 & 0 \\
\hline A796 & $11 / 18 / 45$ & 11 & 7 & A815 & $07 / 22 / 45$ & 0 & 0 \\
\hline A796 & $01 / 13 / 46$ & 0 & 0 & A815 & $09 / 09 / 45$ & 0 & 7 \\
\hline A796 & $03 / 10 / 46$ & 0 & 0. & A816 & $11 / 11 / 45$ & 0 & 12 \\
\hline A797 & $05 / 05 / 46$ & 0 & 3 & A816 & $01 / 06 / 46$ & 0 & 0 \\
\hline A797 & $06 / 30 / 46$ & 0 & 0 & A816 & $02 / 24 / 46$ & 0 & 0 \\
\hline A797 & $08 / 25 / 46$ & 0 & 0 & A817 & $04 / 28 / 46$ & 0 & 2 \\
\hline A798 & $07 / 08 / 45$ & 0 & 0 & A817 & $05 / 19 / 46$ & 3 & 0 \\
\hline A798 & $08 / 26 / 45$ & 7 & 7 & A818 & $07 / 14 / 46$ & 0 & 0 \\
\hline A798 & $09 / 23 / 45$ & 3 & 7 & A819 & $08 / 26 / 45$ & 12 & 0 \\
\hline A798 & $12 / 09 / 45$ & 13 & 0 & A819 & $10 / 21 / 45$ & 5 & 19 \\
\hline A799 & $02 / 03 / 46$ & 0 & 5 & A820 & $01 / 13 / 46$ & 0 & 0 \\
\hline A799 & $04 / 21 / 46$ & 0 & 3 & A821 & $05 / 26 / 46$ & 0 & 1 \\
\hline A800 & $06 / 16 / 46$ & 0 & 0 & A822 & $07 / 15 / 45$ & 0 & 0 \\
\hline A800 & $08 / 11 / 46$ & 4 & 1 & A822 & $09 / 23 / 45$ & 0 & 7 \\
\hline A801 & $07 / 15 / 45$ & 10 & 14 & A822 & $11 / 18 / 45$ & 9 & 5 \\
\hline A801 & $09 / 09 / 45$ & 0 & 0 & A823 & $01 / 13 / 46$ & 4 & 10 \\
\hline A802 & $11 / 11 / 45$ & 4 & 12 & A823 & $03 / 10 / 46$ & 0 & 0 \\
\hline A802 & $02 / 24 / 46$ & 0 & 0 & A823 & $05 / 05 / 46$ & 2 & 1 \\
\hline A803 & $04 / 28 / 46$ & 0 & 0 & A824 & $06 / 30 / 46$ & 0 & 0 \\
\hline A803 & $07 / 28 / 46$ & 0 & 0 & A824 & $08 / 31 / 46$ & 0 & 0 \\
\hline A804 & $07 / 22 / 45$ & 0 & 3 & A825 & $08 / 05 / 45$ & 0 & 0 \\
\hline A804 & $09 / 30 / 45$ & 3 & 11 & A826 & $07 / 01 / 45$ & 3 & 11 \\
\hline A804 & $11 / 18 / 45$ & 0 & 0 & A826 & $08 / 12 / 45$ & 0 & 9 \\
\hline A805 & $01 / 13 / 46$ & 0 & 6 & A827 & $12 / 16 / 45$ & 0 & 10 \\
\hline A805 & $03 / 10 / 46$ & 0 & 0 & A827 & $02 / 10 / 46$ & 5 & 0 \\
\hline A805 & $06 / 02 / 46$ & 0 & 7 & A827 & $03 / 17 / 46$ & 2 & 0 \\
\hline A806 & $08 / 12 / 45$ & 9 & 9 & A827 & $04 / 07 / 46$ & 0 & 4 \\
\hline A806 & $10 / 28 / 45$ & 0 & 0 & A828 & $08 / 04 / 46$ & 6 & 0 \\
\hline A80 & $12 / 23 / 45$ & 0 & 0 & A829 & $07 / 01 / 45$ & 0 & 0 \\
\hline
\end{tabular}


TABLE A.1. (contd)

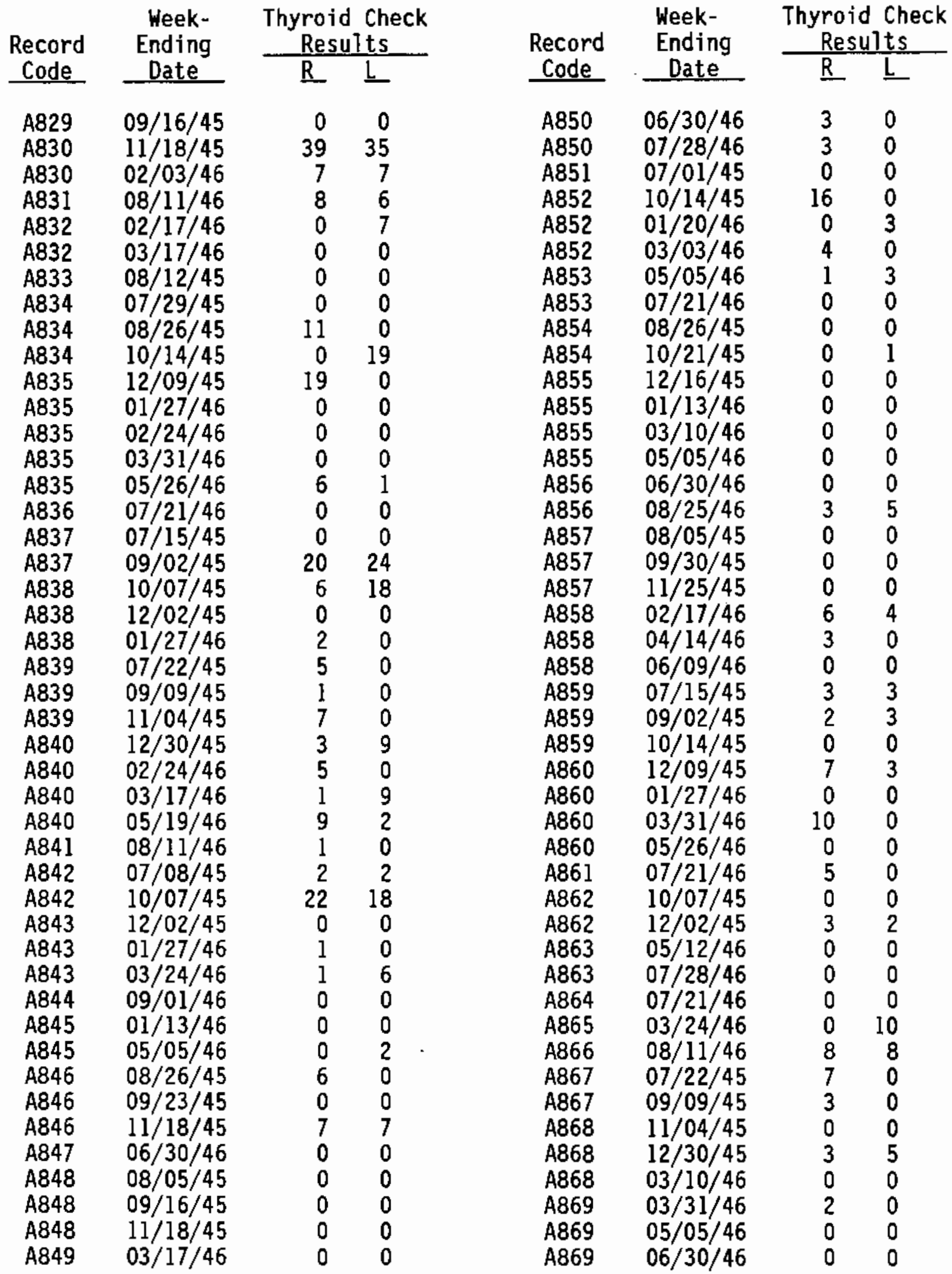


IABLE A.1. (contd)

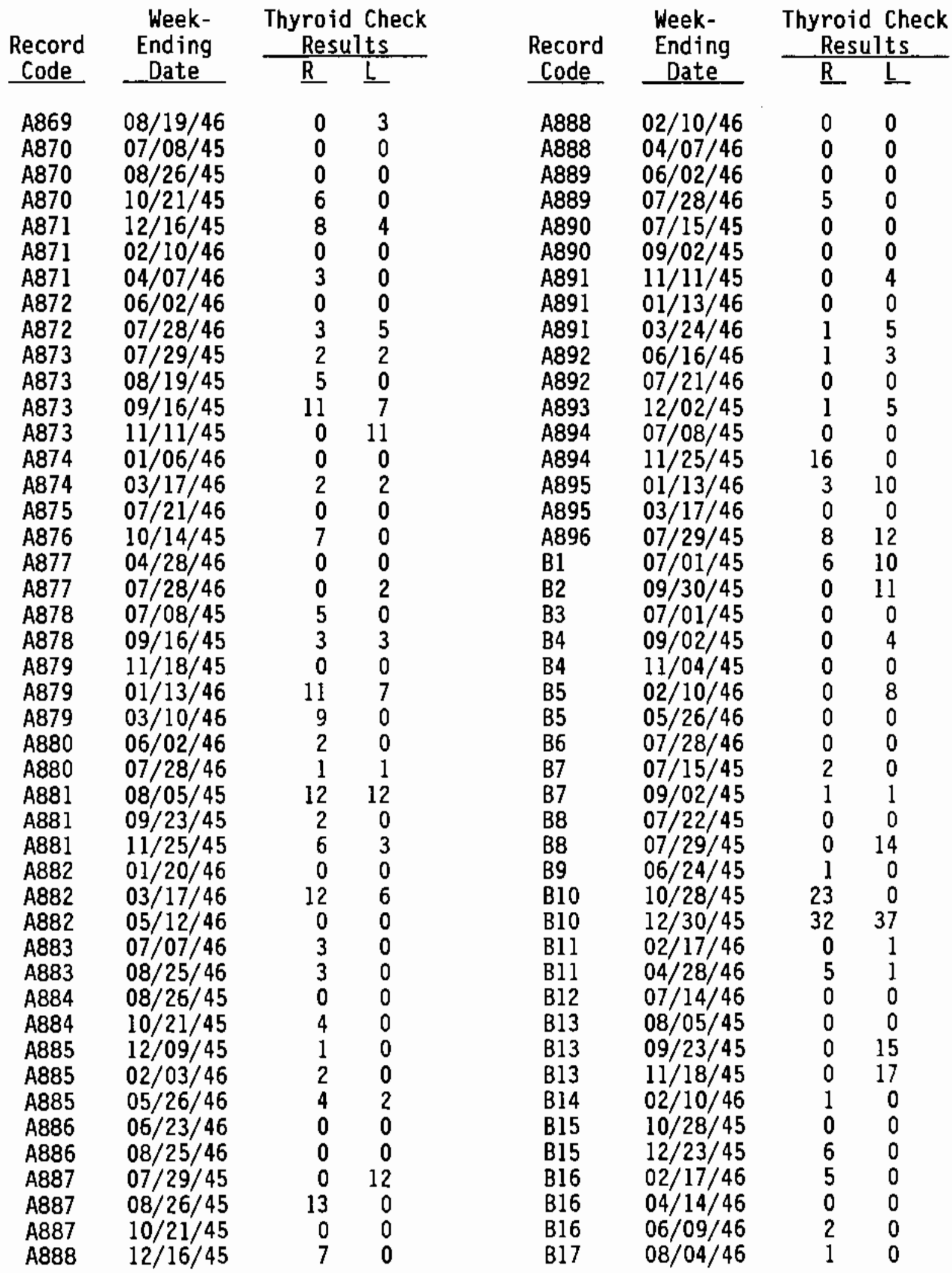


TABLE A.l. (contd)

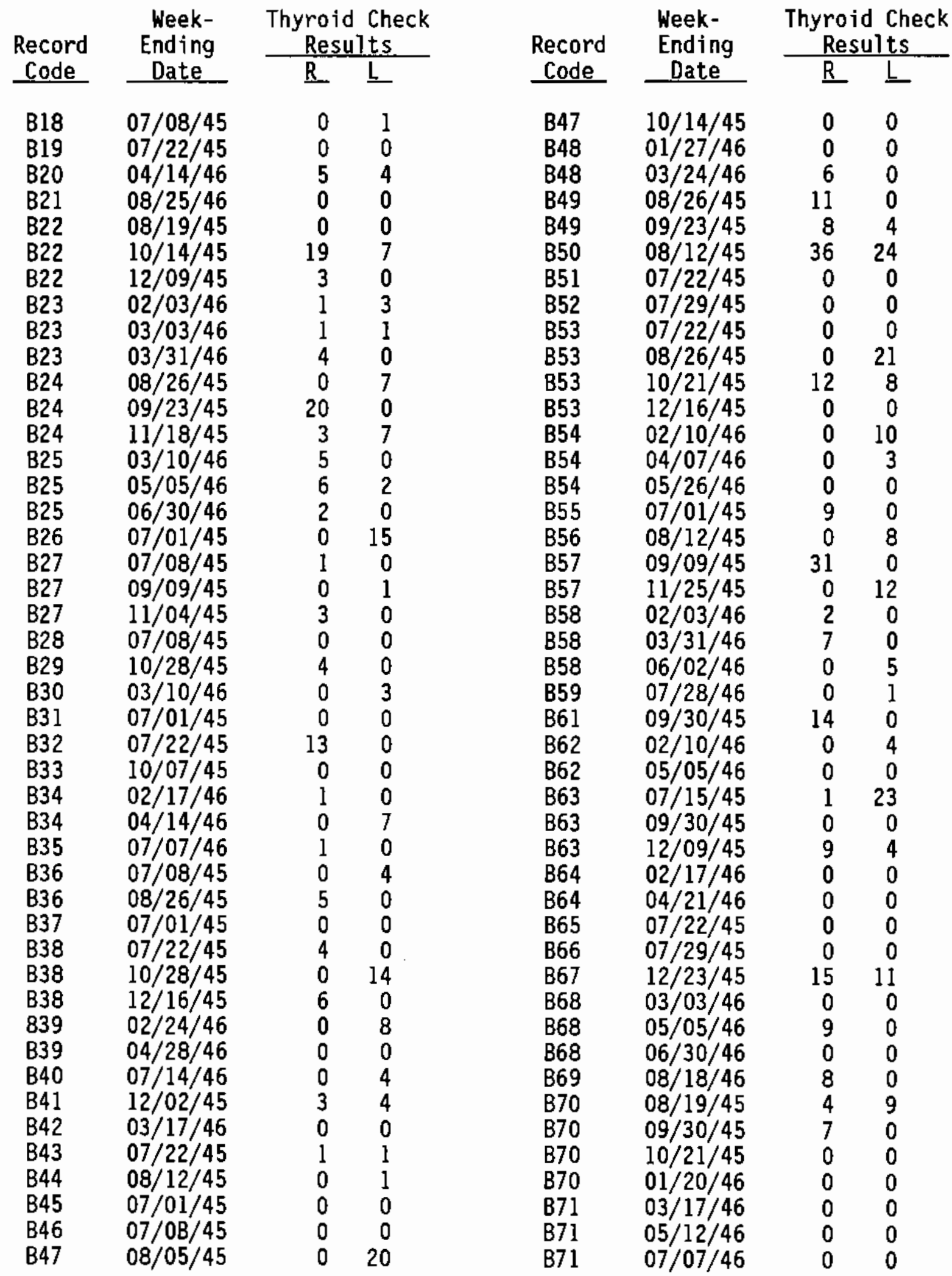


IABLE A.l. (contd)

\begin{tabular}{|c|c|c|c|c|c|c|c|}
\hline \multirow{2}{*}{$\begin{array}{l}\text { Record } \\
\text { Code }\end{array}$} & \multirow{2}{*}{$\begin{array}{c}\text { Week- } \\
\text { Ending } \\
\text { Date } \\
\end{array}$} & \multicolumn{2}{|c|}{$\begin{array}{l}\text { Thyroid Check } \\
\text { Results }\end{array}$} & \multirow{2}{*}{$\begin{array}{l}\text { Record } \\
\text { Code }\end{array}$} & \multirow{2}{*}{$\begin{array}{l}\text { Week- } \\
\text { Ending } \\
\text { Date }\end{array}$} & \multicolumn{2}{|c|}{$\begin{array}{l}\text { Thyroid Check } \\
\text { Results }\end{array}$} \\
\hline & & $\underline{\mathrm{R}}$ & $\underline{\underline{L}}$ & & & $\underline{R}$ & $\underline{L}$ \\
\hline B72 & $08 / 05 / 45$ & 8 & 0 & B98 & $08 / 31 / 46$ & 0 & 0 \\
\hline B73 & $07 / 08 / 45$ & 5 & 17 & B99 & $07 / 29 / 45$ & 0 & 0 \\
\hline B73 & $08 / 26 / 45$ & 9 & 17 & B99 & $10 / 07 / 45$ & 0 & 0 \\
\hline B73 & $11 / 18 / 45$ & 3 & 7 & B99 & $12 / 02 / 45$ & 0 & 16 \\
\hline B74 & $02 / 03 / 46$ & 6 & 1 & B100 & $01 / 20 / 46$ & 1 & 0 \\
\hline B74 & $03 / 03 / 46$ & 4 & 0 & B100 & $03 / 24 / 46$ & 4 & 0 \\
\hline B74 & $04 / 28 / 46$ & 0 & 0 & Bloo & $05 / 19 / 46$ & 0 & 2 \\
\hline B74 & $06 / 30 / 46$ & 0 & 0 & Blol & $07 / 29 / 45$ & 3 & 3 \\
\hline B75 & $10 / 14 / 45$ & 0 & 5 & Blo2 & $08 / 05 / 45$ & 3 & 3 \\
\hline B76 & $08 / 12 / 45$ & 7 & l & B102 & $09 / 16 / 45$ & 0 & 0 \\
\hline B77 & $07 / 01 / 45$ & 0 & 0 & B103 & $07 / 01 / 45$ & 3 & 7 \\
\hline B78 & $07 / 28 / 46$ & 3 & 0 & B103 & $07 / 22 / 45$ & 0 & 0 \\
\hline B79 & $07 / 08 / 45$ & 0 & 0 & B104 & $08 / 19 / 45$ & 0 & 10 \\
\hline B80 & $08 / 12 / 45$ & 0 & 0 & B104 & $09 / 09 / 45$ & 12 & 0 \\
\hline B81 & $07 / 08 / 45$ & 0 & 0 & B104 & $11 / 11 / 45$ & 28 & 12 \\
\hline B81 & $08 / 12 / 45$ & 0 & 0 & B104 & $01 / 06 / 46$ & 0 & 0 \\
\hline B82 & $09 / 02 / 45$ & 6 & 0 & B105 & $04 / 28 / 46$ & 0 & 0 \\
\hline$B 82$ & $10 / 28 / 45$ & 0 & 0 & B106 & $07 / 01 / 45$ & 7 & 3 \\
\hline$B 82$ & $12 / 23 / 45$ & 0 & 0 & B107 & $08 / 19 / 45$ & 9 & 9 \\
\hline$B 83$ & $01 / 27 / 46$ & 0 & 0 & B107 & $09 / 09 / 45$ & 0 & 5 \\
\hline B83 & $03 / 17 / 46$ & 5 & 6 & B108 & $09 / 30 / 45$ & 0 & 0 \\
\hline B83 & $05 / 12 / 46$ & 2 & 0 & B109 & $07 / 01 / 45$ & 0 & 0 \\
\hline B84 & $07 / 07 / 46$ & 2 & 0 & Bl10 & $08 / 05 / 45$ & 0 & 4 \\
\hline B85 & $07 / 01 / 45$ & 0 & 0 & Bl11 & $07 / 01 / 45$ & 0 & 8 \\
\hline B86 & $07 / 08 / 45$ & 0 & 0 & 8112 & $08 / 26 / 45$ & 5 & 0 \\
\hline B86 & $08 / 26 / 45$ & 0 & 0 & B112 & $10 / 14 / 45$ & 11 & 3 \\
\hline B86 & $10 / 21 / 45$ & 0 & 0 & B112 & $01 / 06 / 46$ & 0 & 4 \\
\hline 886 & $12 / 16 / 45$ & 0 & 0 & Bl13 & $03 / 31 / 46$ & 0 & 0 \\
\hline B87 & $02 / 10 / 46$ & 0 & 0 & Bl13 & $06 / 16 / 46$ & 5 & 0 \\
\hline 887 & $05 / 26 / 46$ & 2 & 0 & Bl13 & $07 / 21 / 46$ & 0 & 0 \\
\hline B88 & $07 / 21 / 46$ & 0 & 3 & B114 & $07 / 15 / 45$ & 7 & 0 \\
\hline B89 & $07 / 08 / 45$ & 0 & 6 & B1 15 & $07 / 08 / 45$ & 6 & 0 \\
\hline B90 & $07 / 29 / 45$ & 0 & 0 & Bl 16 & $07 / 01 / 45$ & 0 & 0 \\
\hline B90 & $08 / 05 / 45$ & 10 & 10 & Bl17 & $08 / 26 / 45$ & 0 & 0 \\
\hline B91 & $08 / 12 / 45$ & 0 & 0 & B118 & $07 / 08 / 45$ & 0 & 0 \\
\hline B92 & $07 / 01 / 45$ & 5 & 0 & B119 & $08 / 26 / 45$ & 0 & 1 \\
\hline B93 & $08 / 26 / 45$ & 5 & 0 & B119 & $10 / 21 / 45$ & 0 & 2 \\
\hline B93 & $09 / 30 / 45$ & 0 & 0 & Bl19 & $12 / 16 / 45$ & 20 & 0 \\
\hline B93 & $10 / 14 / 45$ & 23 & 11 & B120 & $02 / 17 / 46$ & 0 & 0 \\
\hline B94 & $11 / 18 / 45$ & 0 & 1 & Bl20 & $04 / 14 / 46$ & 2 & 0 \\
\hline B96 & $08 / 26 / 45$ & 10 & 10 & $\mathrm{~B} 120$ & $06 / 09 / 46$ & 0 & 0 \\
\hline B96 & $09 / 30 / 45$ & 0 & 5 & B121 & $08 / 18 / 46$ & 0 & 0 \\
\hline B96 & $11 / 25 / 45$ & 10 & 14 & B121 & $08 / 31 / 46$ & 5 & 2 \\
\hline B97 & $03 / 24 / 46$ & 1 & 10 & $\mathrm{Bl} 22$ & $07 / 07 / 46$ & 0 & 0 \\
\hline B97 & $06 / 09 / 46$ & 0 & 5 & 8123 & $07 / 08 / 45$ & 1 & 0 \\
\hline
\end{tabular}


TABLE A.1. (contd)

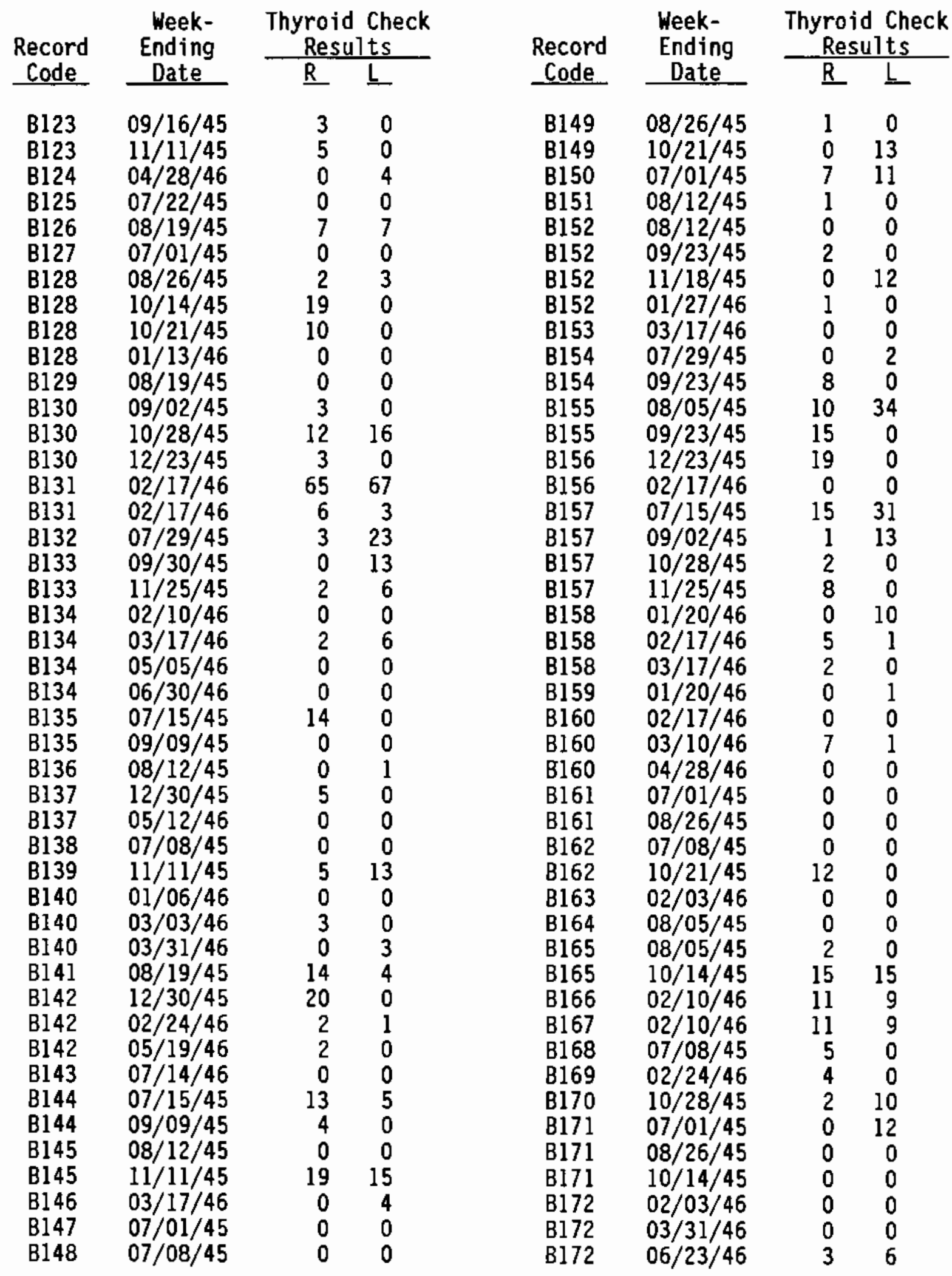


TABLE A.1. (contd)

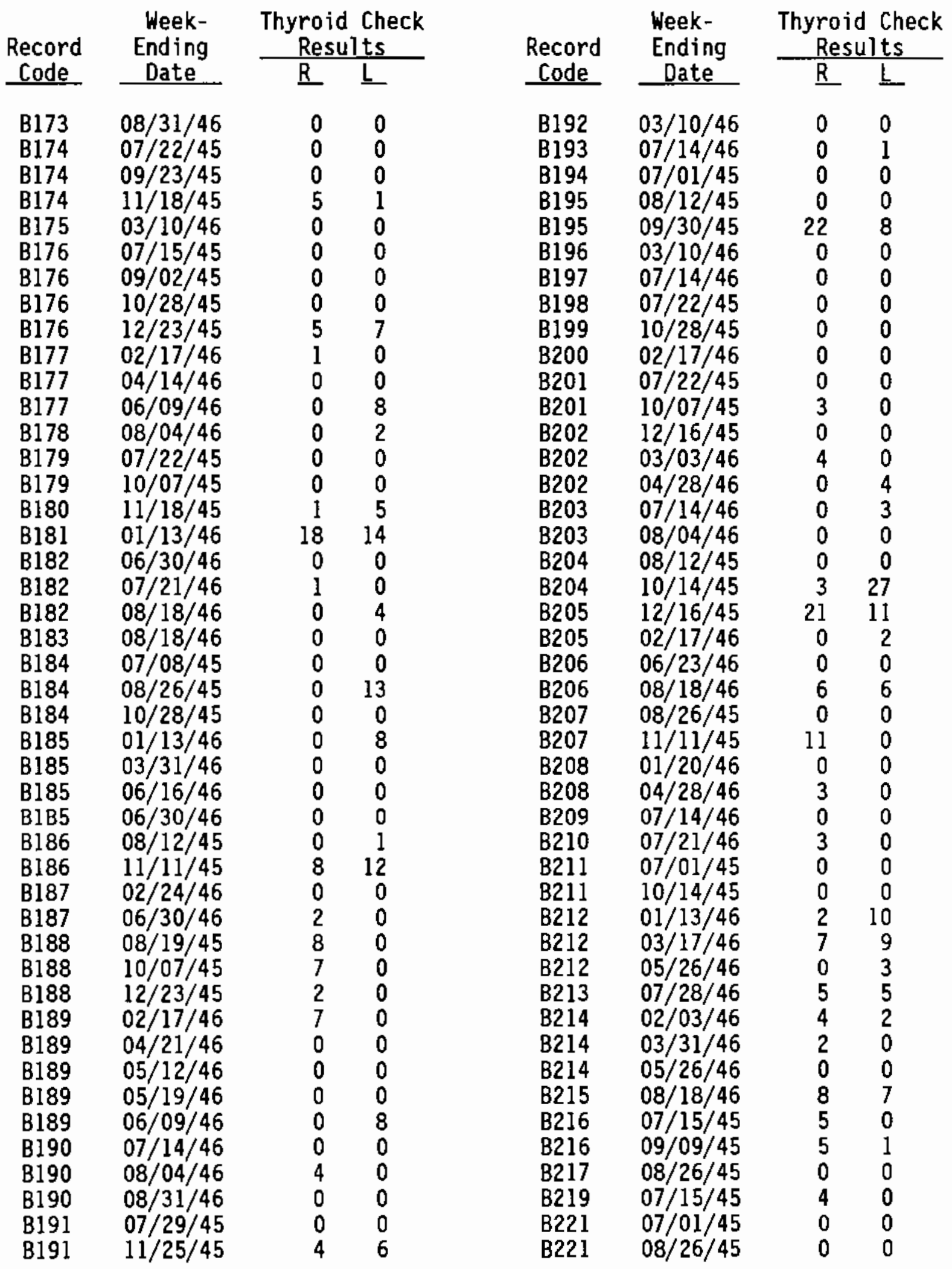


IABLE A.1. (contd)

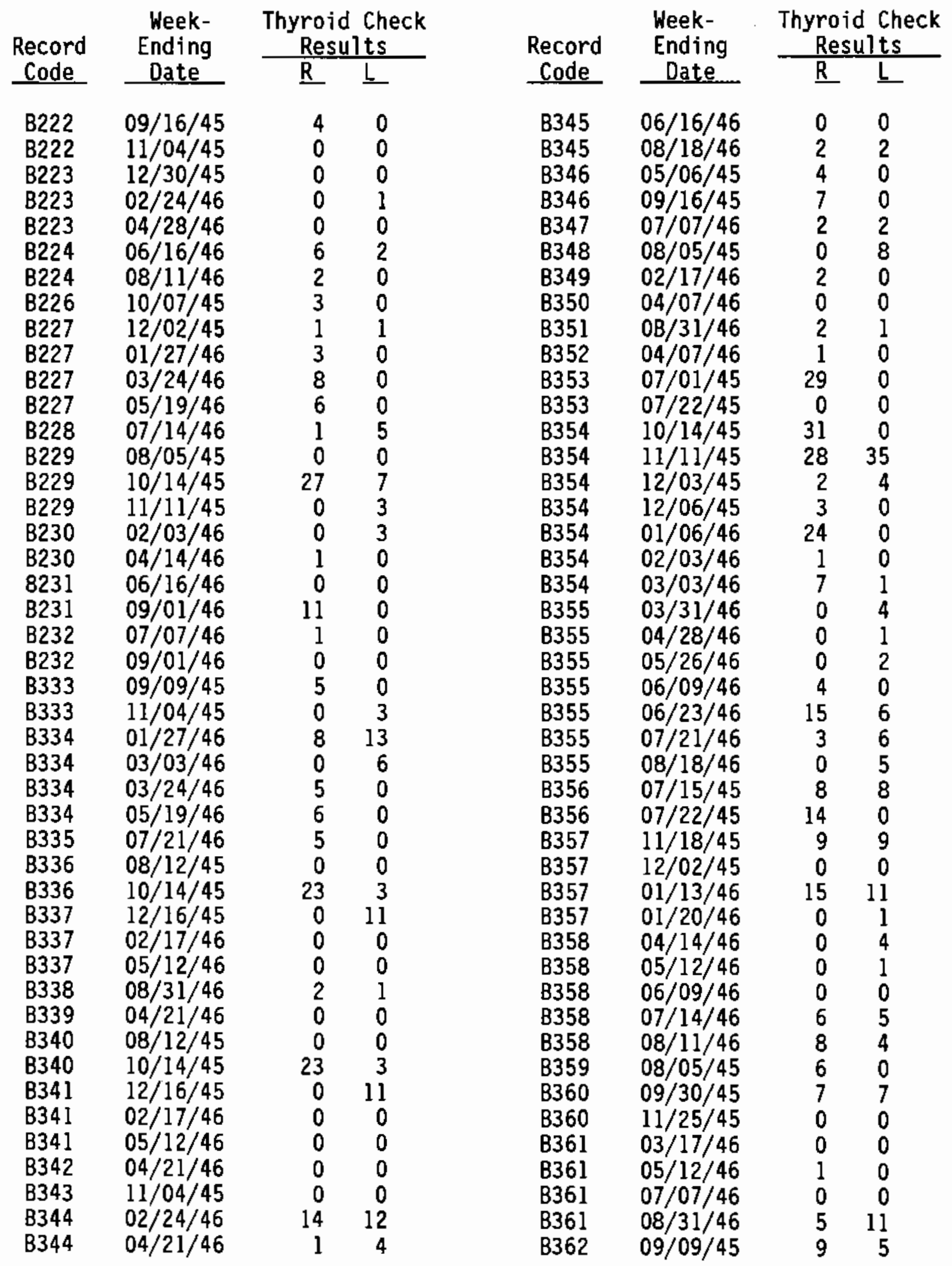


IABLE A. 1. (contd)

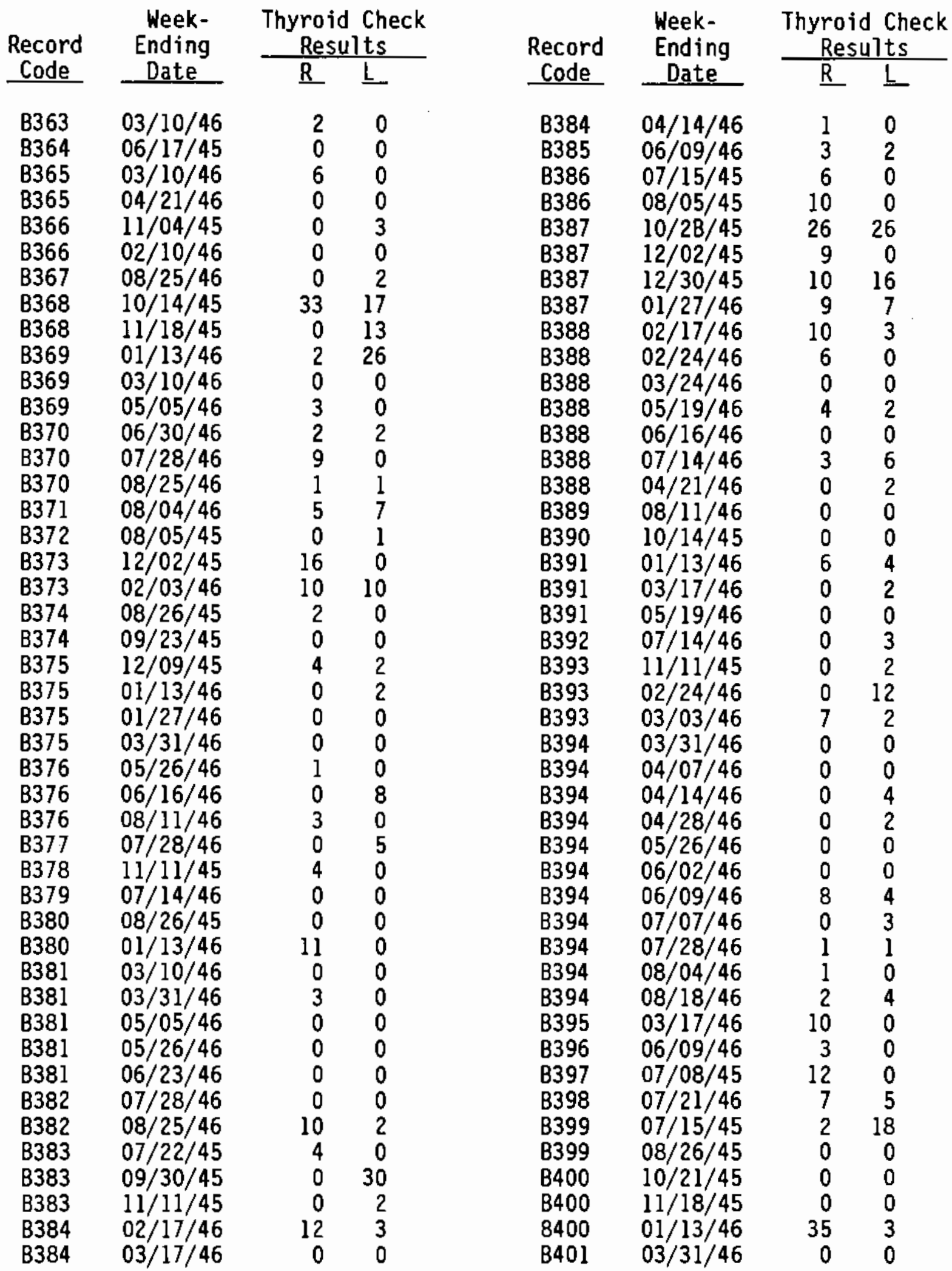


TABLE A.l. (contd)

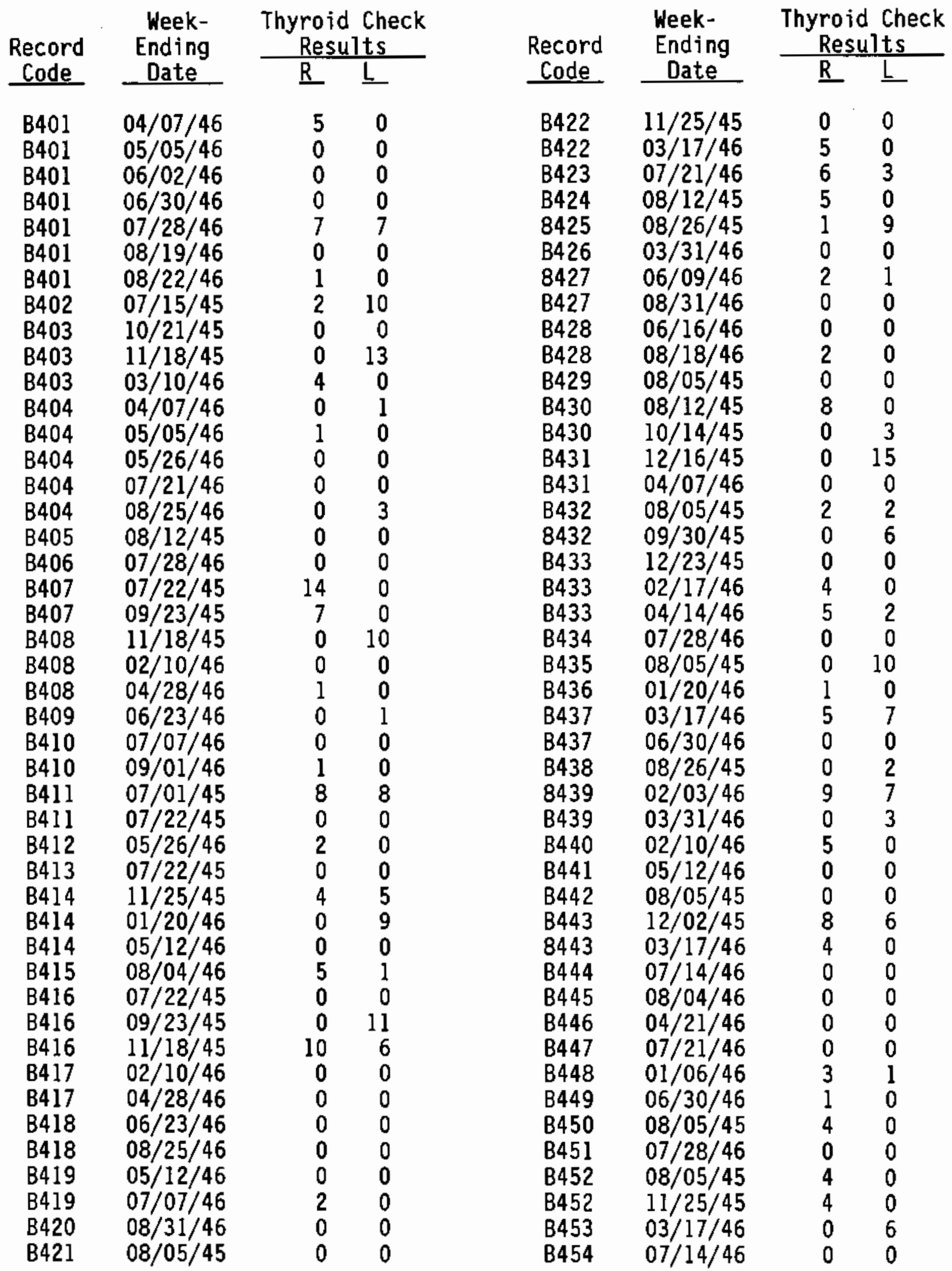


TABLE A.1. (contd)

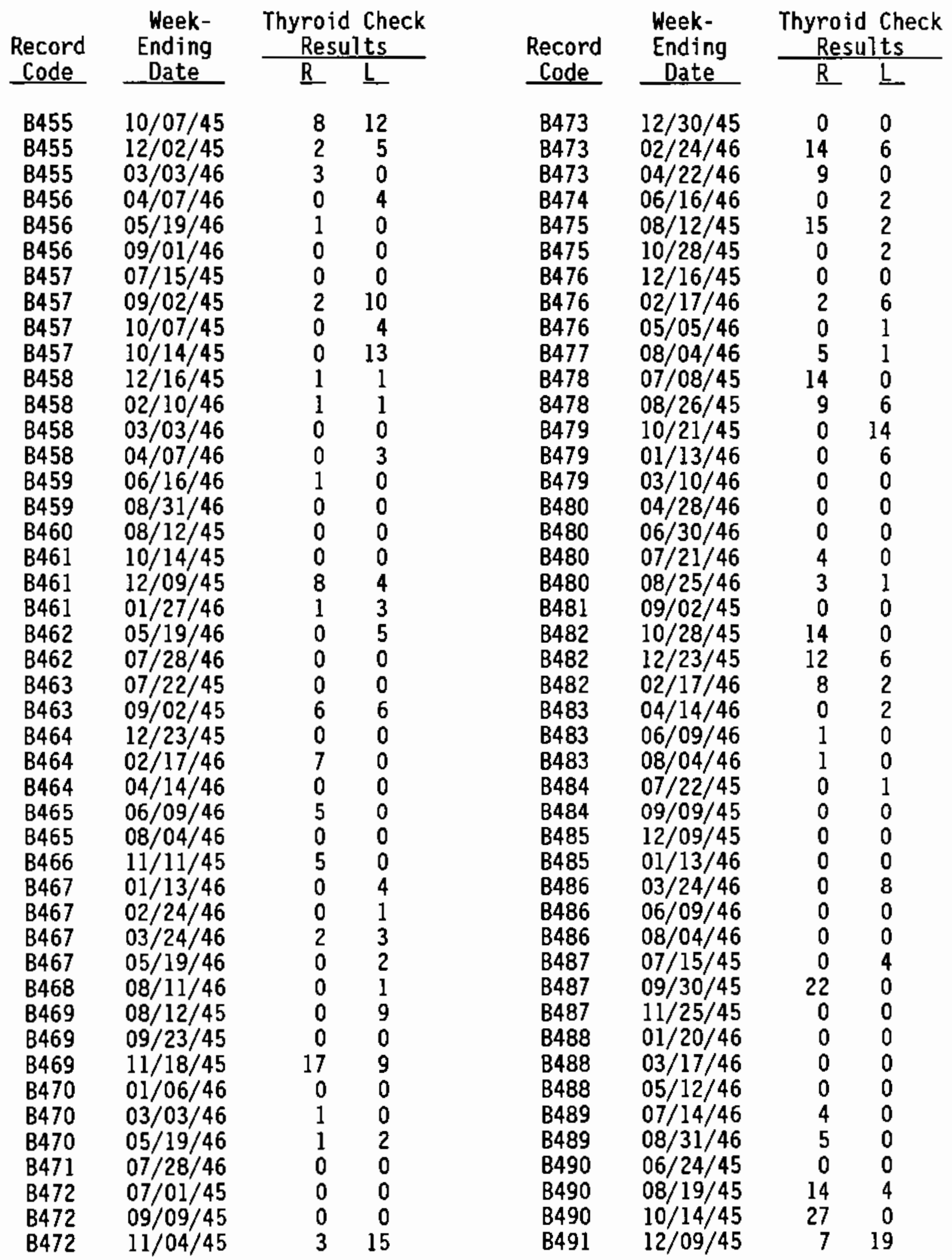


TABLE A.1. (contd)

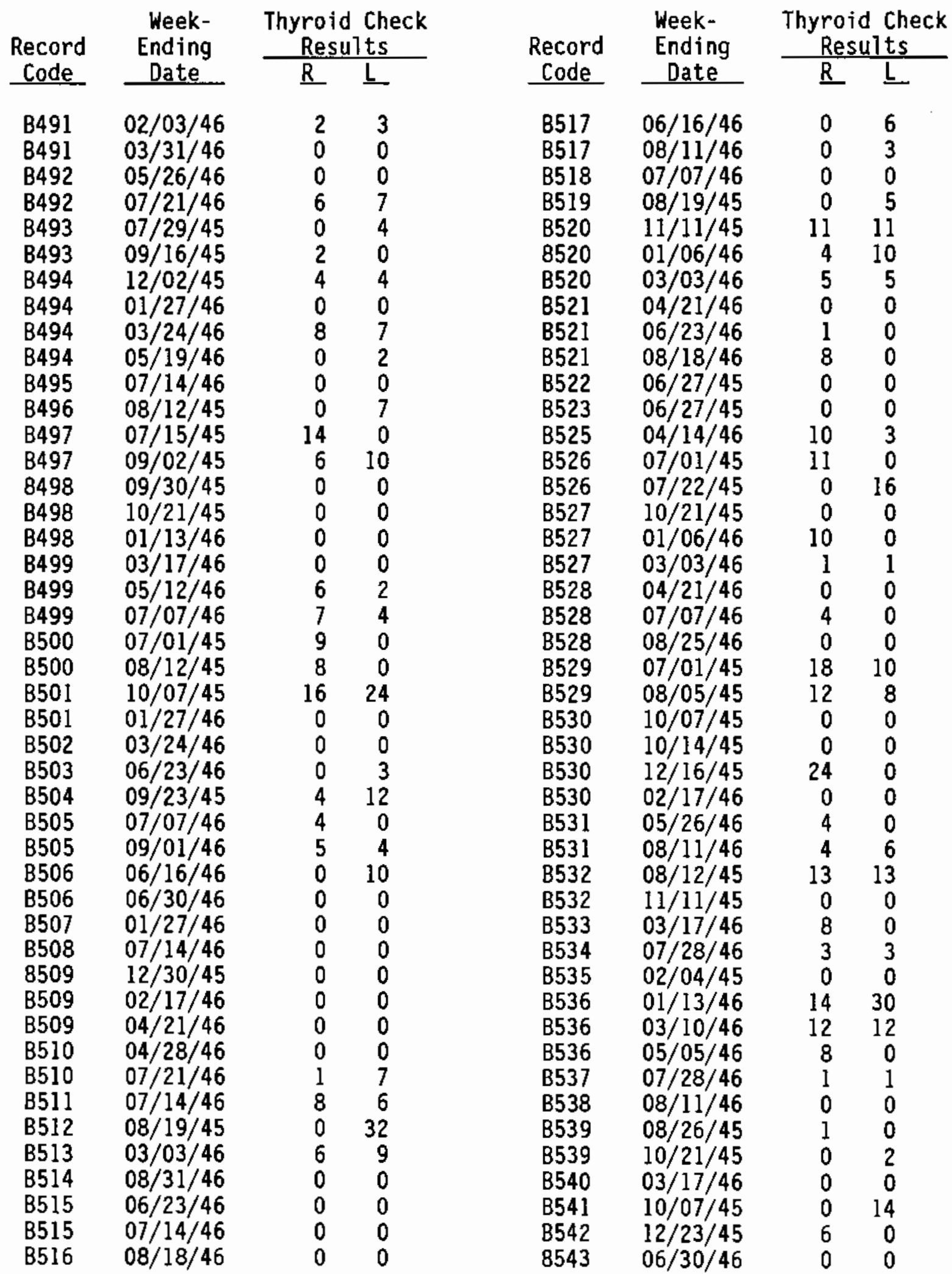


TABLE A.1. (contd)

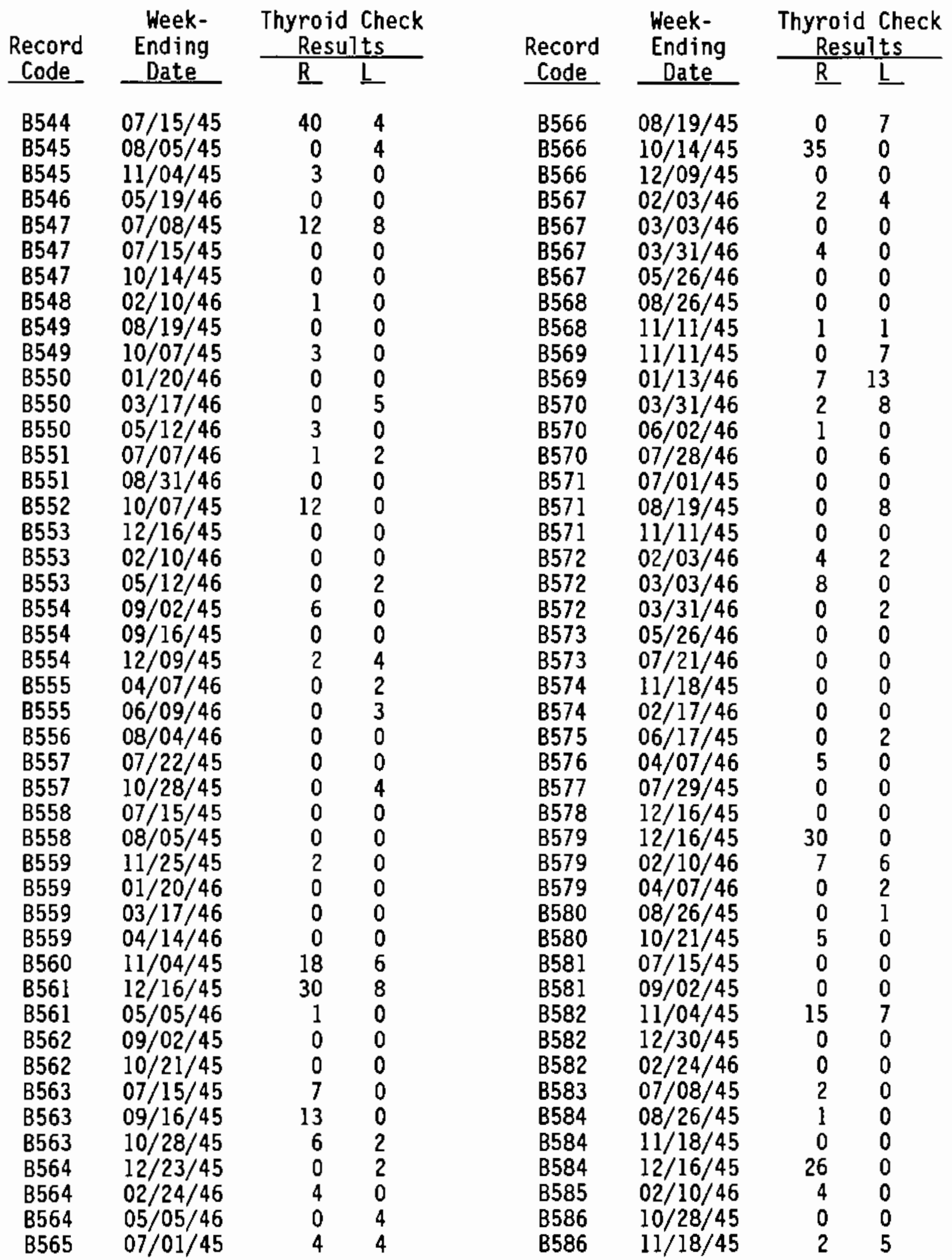


TABLE A.1. (contd)

\begin{tabular}{|c|c|c|c|c|c|c|c|}
\hline \multirow{2}{*}{$\begin{array}{l}\text { Record } \\
\text { Code }\end{array}$} & \multirow{2}{*}{$\begin{array}{c}\text { Week- } \\
\text { Ending } \\
\text { Date } \\
\end{array}$} & \multicolumn{2}{|c|}{$\begin{array}{l}\text { Thyroid Check } \\
\text { Results }\end{array}$} & \multirow{2}{*}{$\begin{array}{l}\text { Record } \\
\text { Code }\end{array}$} & \multirow{2}{*}{$\begin{array}{l}\text { Week- } \\
\text { Ending } \\
\text { Date } \\
\end{array}$} & \multicolumn{2}{|c|}{$\begin{array}{c}\text { Thyroid Check } \\
\text { Results }\end{array}$} \\
\hline & & & & & & $\underline{R}$ & $\underline{L}$ \\
\hline B587 & $01 / 20 / 46$ & 6 & 3 & B608 & $11 / 18 / 45$ & 6 & 2 \\
\hline B587 & $03 / 03 / 46$ & 0 & 4 & $\mathrm{~B} 608$ & $01 / 13 / 46$ & 20 & 14 \\
\hline B587 & $05 / 12 / 46$ & 0 & 0 & $B 609$ & $04 / 21 / 46$ & 0 & 3 \\
\hline B588 & $07 / 07 / 46$ & 4 & 2 & B609 & $06 / 30 / 46$ & 0 & 0 \\
\hline B588 & $08 / 25 / 46$ & 0 & 1 & B610 & $07 / 01 / 45$ & 11 & 3 \\
\hline B589 & $08 / 26 / 45$ & 0 & 0 & B610 & $09 / 02 / 45$ & 10 & 16 \\
\hline B589 & $10 / 28 / 45$ & 0 & 0 & $\mathrm{~B} 611$ & $09 / 23 / 45$ & 0 & 0 \\
\hline B590 & $02 / 03 / 46$ & 0 & 0 & $\mathrm{~B} 611$ & $11 / 18 / 45$ & 7 & 6 \\
\hline B590 & $03 / 31 / 46$ & 8 & 8 & B612 & $01 / 13 / 46$ & 3 & 6 \\
\hline B59l & $07 / 21 / 46$ & 0 & 0 & $\mathrm{~B} 612$ & $03 / 17 / 46$ & 0 & 2 \\
\hline B592 & $06 / 24 / 45$ & 0 & 0 & $\mathrm{~B} 612$ & $05 / 05 / 46$ & 0 & 0 \\
\hline B592 & $08 / 19 / 45$ & 3 & 0 & $\mathrm{~B} 613$ & $06 / 30 / 46$ & 2 & 1 \\
\hline B592 & $10 / 14 / 45$ & 11 & 0 & B614 & $07 / 22 / 45$ & 0 & 0 \\
\hline B593 & $01 / 27 / 46$ & 0 & 2 & B614 & $09 / 09 / 45$ & 11 & 0 \\
\hline B593 & $05 / 26 / 46$ & 0 & 7 & B614 & $11 / 11 / 45$ & 0 & 0 \\
\hline B594 & $04 / 21 / 46$ & 1 & 0 & $\mathrm{~B} 615$ & $01 / 13 / 46$ & 4 & 0 \\
\hline B595 & $07 / 15 / 45$ & 0 & 8 & B615 & $04 / 07 / 46$ & 10 & 0 \\
\hline B595 & $08 / 26 / 45$ & 0 & 14 & B616 & $06 / 23 / 46$ & 0 & 0 \\
\hline B595 & $10 / 14 / 45$ & 2 & 10 & B616 & $07 / 21 / 46$ & 2 & 1 \\
\hline B596 & $12 / 30 / 45$ & 17 & 0 & B617 & $07 / 15 / 45$ & 4 & 0 \\
\hline B596 & $02 / 24 / 46$ & 5 & 0 & $\mathrm{~B} 618$ & $07 / 01 / 45$ & 0 & 13 \\
\hline B596 & $03 / 17 / 46$ & 6 & 6 & B618 & $08 / 26 / 45$ & 1 & 5 \\
\hline 8596 & $04 / 14 / 46$ & 4 & 1 & B618 & $11 / 11 / 45$ & 23 & 27 \\
\hline B596 & $05 / 12 / 46$ & 1 & 0 & $B 619$ & $02 / 10 / 46$ & 0 & 7 \\
\hline B597 & $06 / 16 / 46$ & 6 & 0 & $B 619$ & $02 / 17 / 46$ & 2 & 0 \\
\hline B597 & $08 / 11 / 46$ & 0 & 0 & B619 & $02 / 24 / 46$ & 0 & 0 \\
\hline B598 & $09 / 02 / 45$ & 17 & 5 & $\mathrm{~B} 620$ & $04 / 28 / 46$ & 8 & 0 \\
\hline B598 & $10 / 28 / 45$ & 2 & 2 & $\mathrm{~B} 621$ & $07 / 28 / 46$ & 0 & 9 \\
\hline B599 & $12 / 23 / 45$ & 0 & 9 & $\mathrm{~B} 622$ & $07 / 22 / 45$ & 3 & 0 \\
\hline B599 & $05 / 05 / 46$ & 0 & 4 & $\mathrm{~B} 623$ & $11 / 25 / 45$ & 0 & 4 \\
\hline $\mathrm{B} 600$ & $07 / 07 / 46$ & 4 & 4 & B623 & $01 / 20 / 46$ & 5 & 0 \\
\hline $\mathrm{B} 600$ & $08 / 31 / 46$ & 0 & 0 & B624 & $03 / 24 / 46$ & 8 & 1 \\
\hline $\mathrm{B} 601$ & $04 / 28 / 46$ & 0 & 10 & B624 & $08 / 04 / 46$ & 0 & 0 \\
\hline $\mathrm{B} 601$ & $06 / 23 / 46$ & 0 & 4 & B624 & $09 / 01 / 46$ & 0 & 0 \\
\hline $\mathrm{B} 602$ & $08 / 18 / 46$ & 2 & 4 & B625 & $09 / 14 / 46$ & 2 & 3 \\
\hline B603 & $04 / 21 / 46$ & 0 & 0 & B626 & $07 / 15 / 45$ & 0 & 0 \\
\hline $\mathrm{B} 603$ & $06 / 23 / 46$ & 0 & 0 & B626 & $09 / 09 / 45$ & 0 & 0 \\
\hline B603 & $08 / 25 / 46$ & 1 & 5 & B626 & $11 / 04 / 45$ & 0 & 25 \\
\hline B604 & $08 / 26 / 45$ & 10 & 0 & $\mathrm{~B} 627$ & $02 / 03 / 46$ & 8 & 6 \\
\hline$B 605$ & $10 / 21 / 45$ & 14 & 0 & $\mathrm{~B} 627$ & $03 / 24 / 46$ & 0 & 4 \\
\hline B605 & $12 / 02 / 45$ & 4 & 2 & B627 & $05 / 26 / 46$ & 0 & 0 \\
\hline B605 & $01 / 13 / 46$ & 13 & 3 & B628 & $07 / 21 / 46$ & 2 & 2 \\
\hline B607 & $07 / 01 / 45$ & 0 & 8 & B629 & $06 / 23 / 46$ & 7 & 0 \\
\hline B607 & $08 / 19 / 45$ & 19 & 12 & B630 & $04 / 07 / 46$ & 3 & 0 \\
\hline B608 & $09 / 16 / 45$ & 1 & 1 & B631 & $08 / 11 / 46$ & 4 & 2 \\
\hline
\end{tabular}


IABLE A.1. (contd)

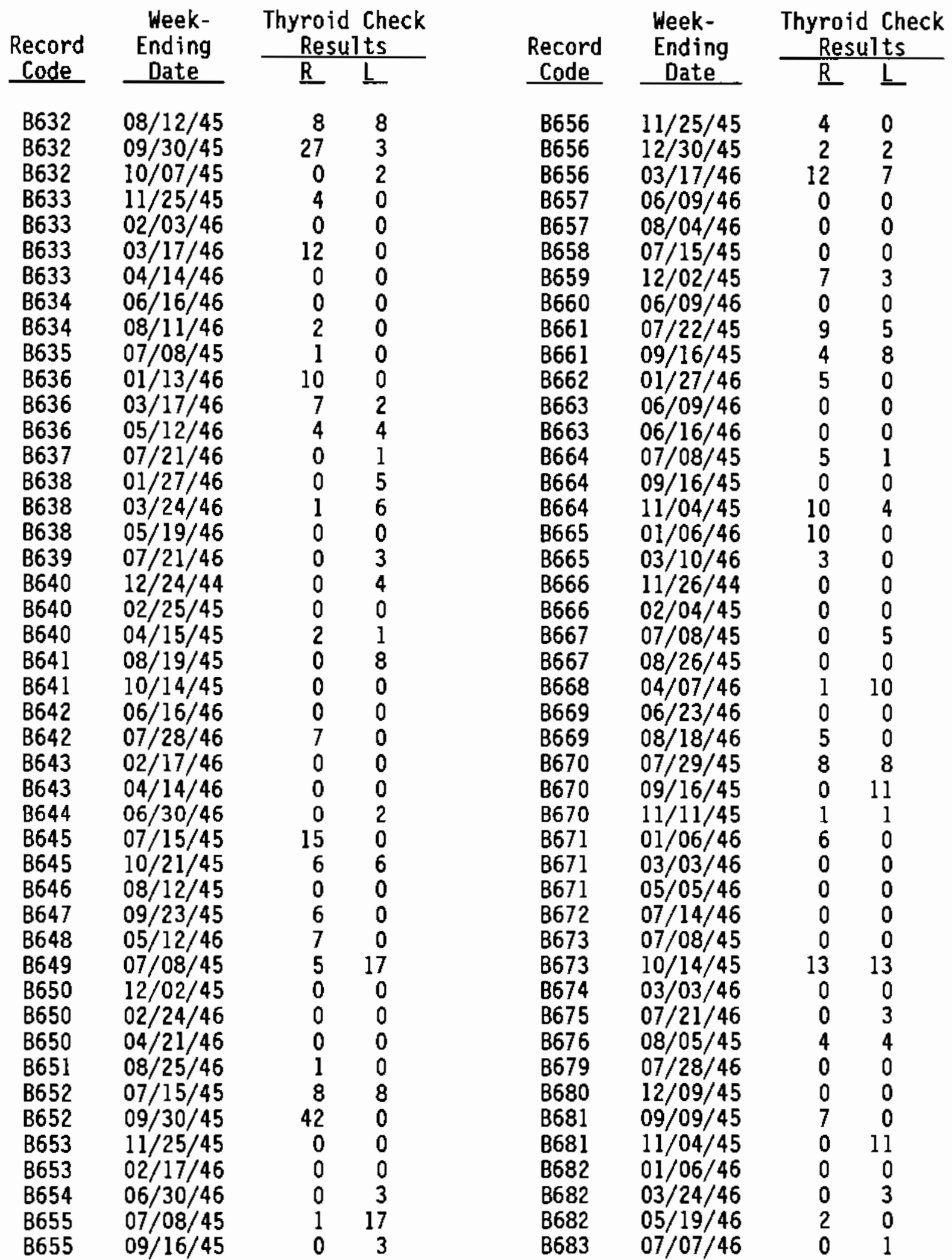


IABLE'A.1. (contd)

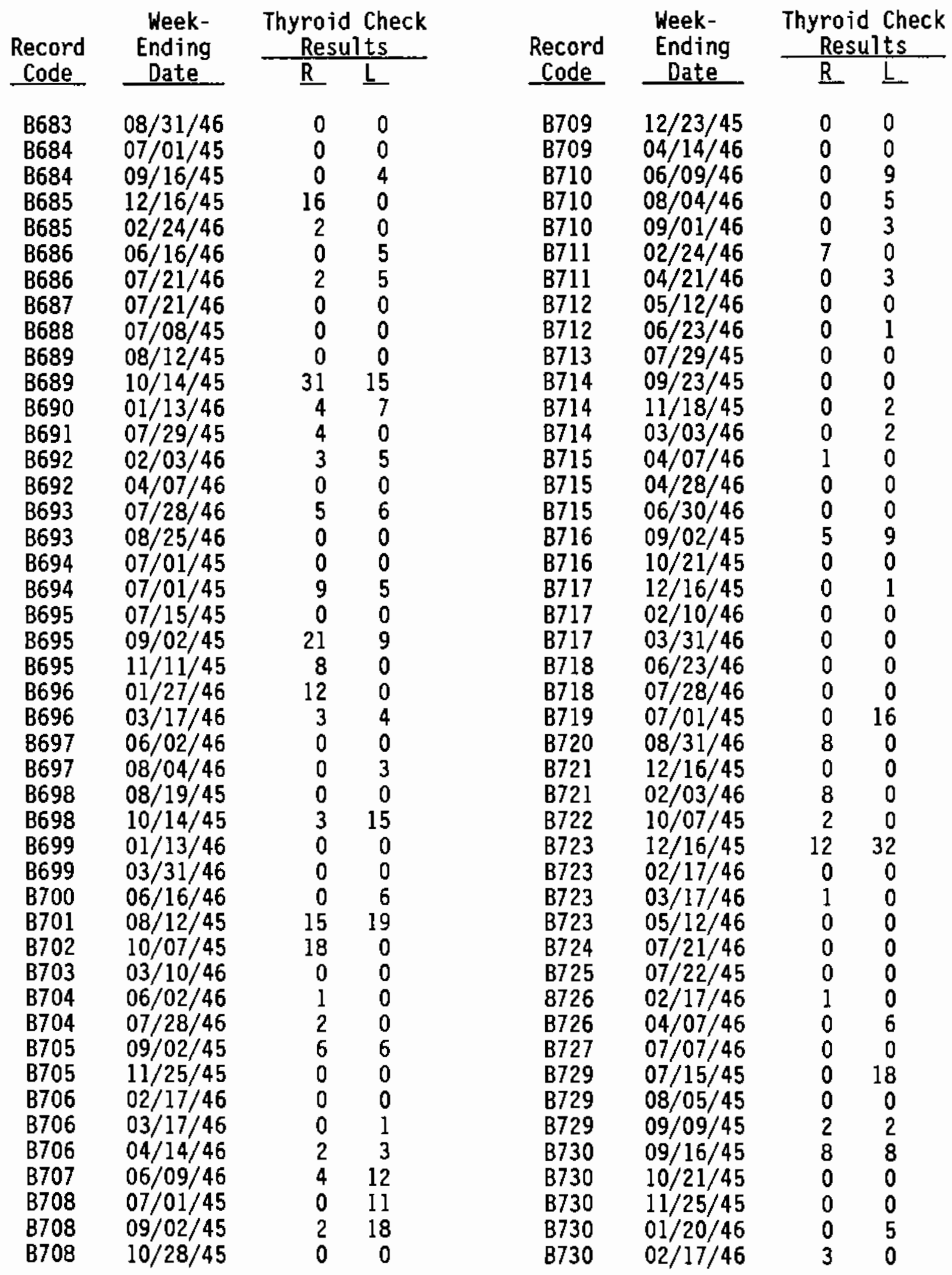


TABLE A.1. (contd)

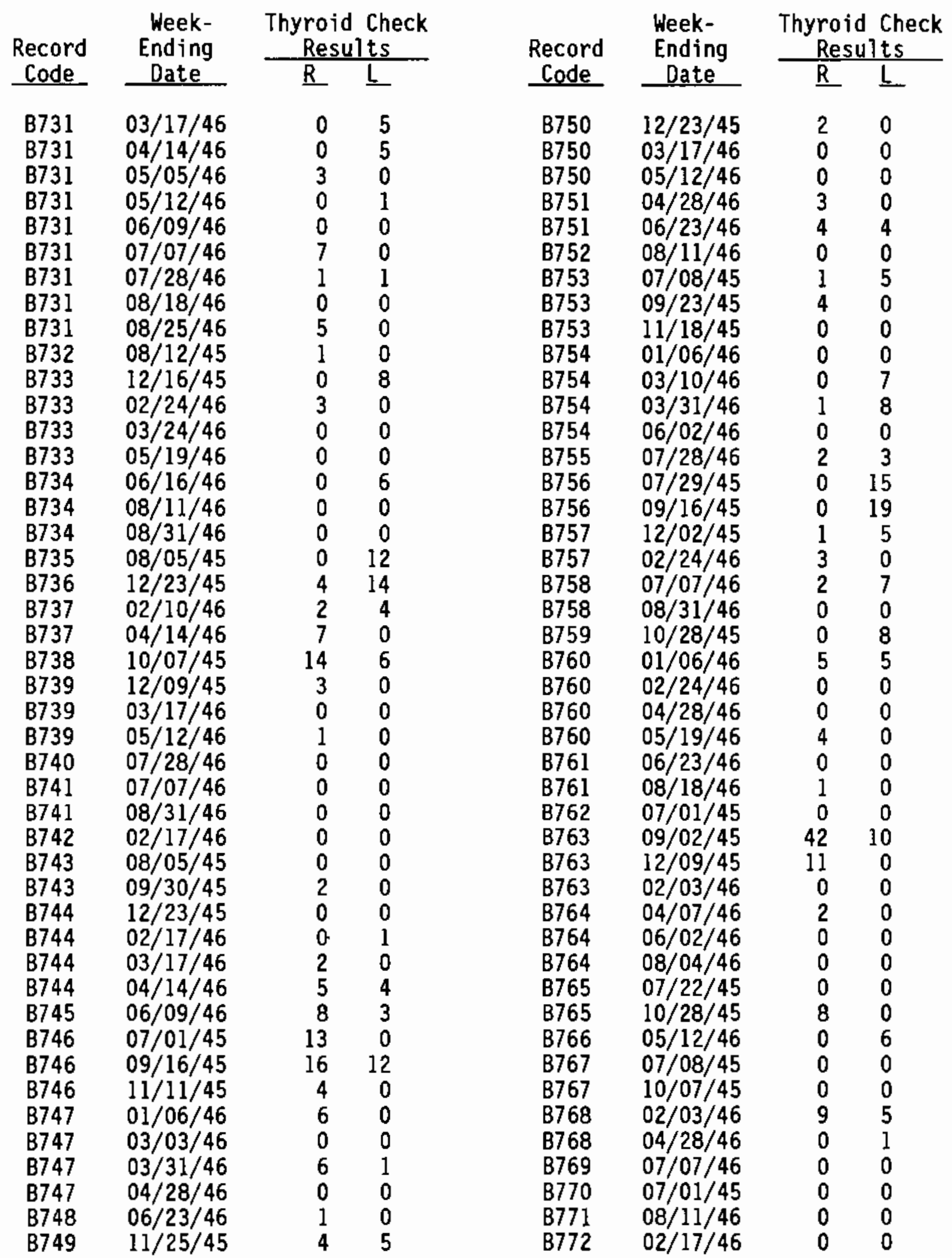


IABLE A.1. (contd)

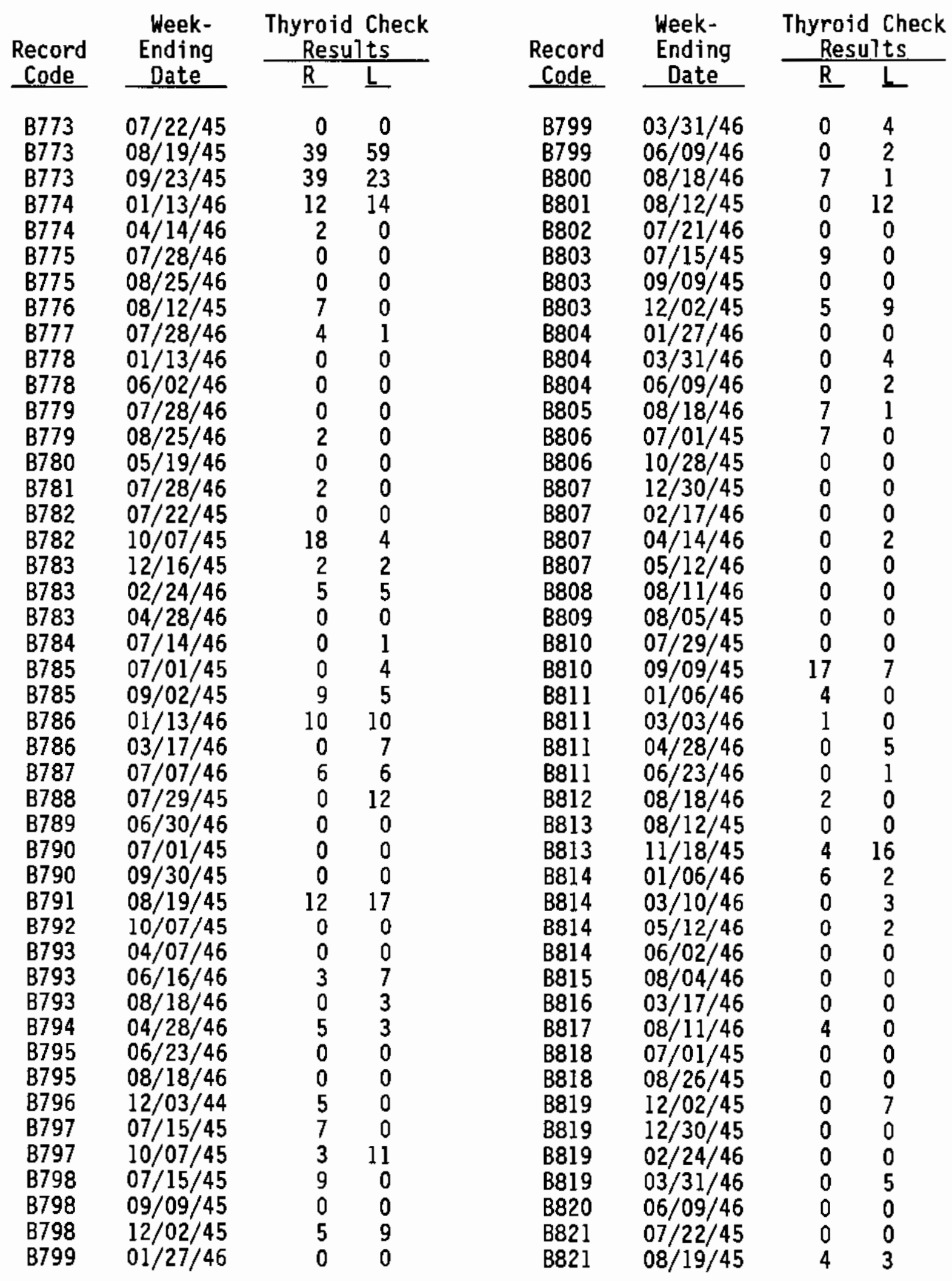


TABLE A.1. (contd)

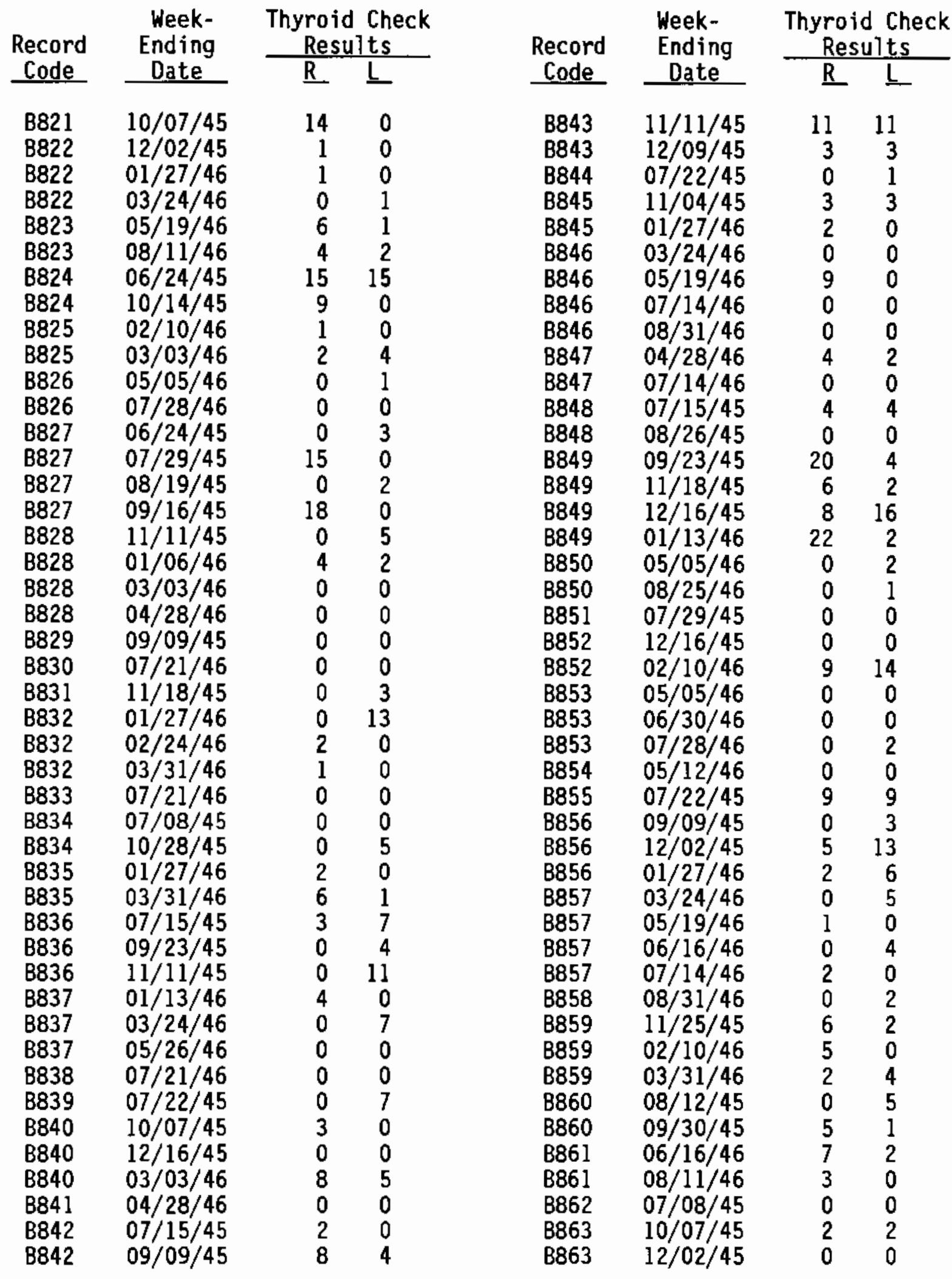


TABLE A.1. (contd)

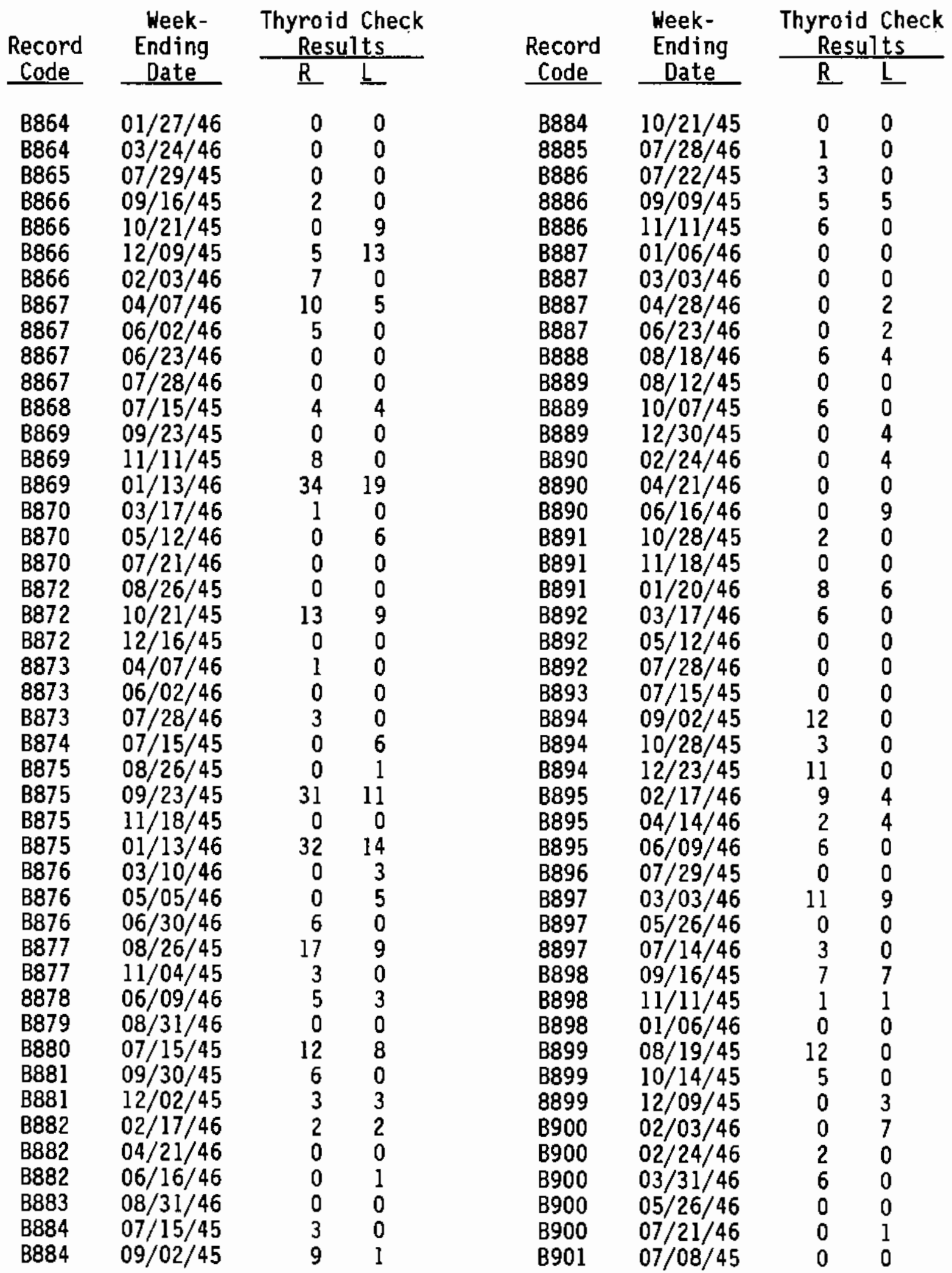


TABLE A.1. (contd)

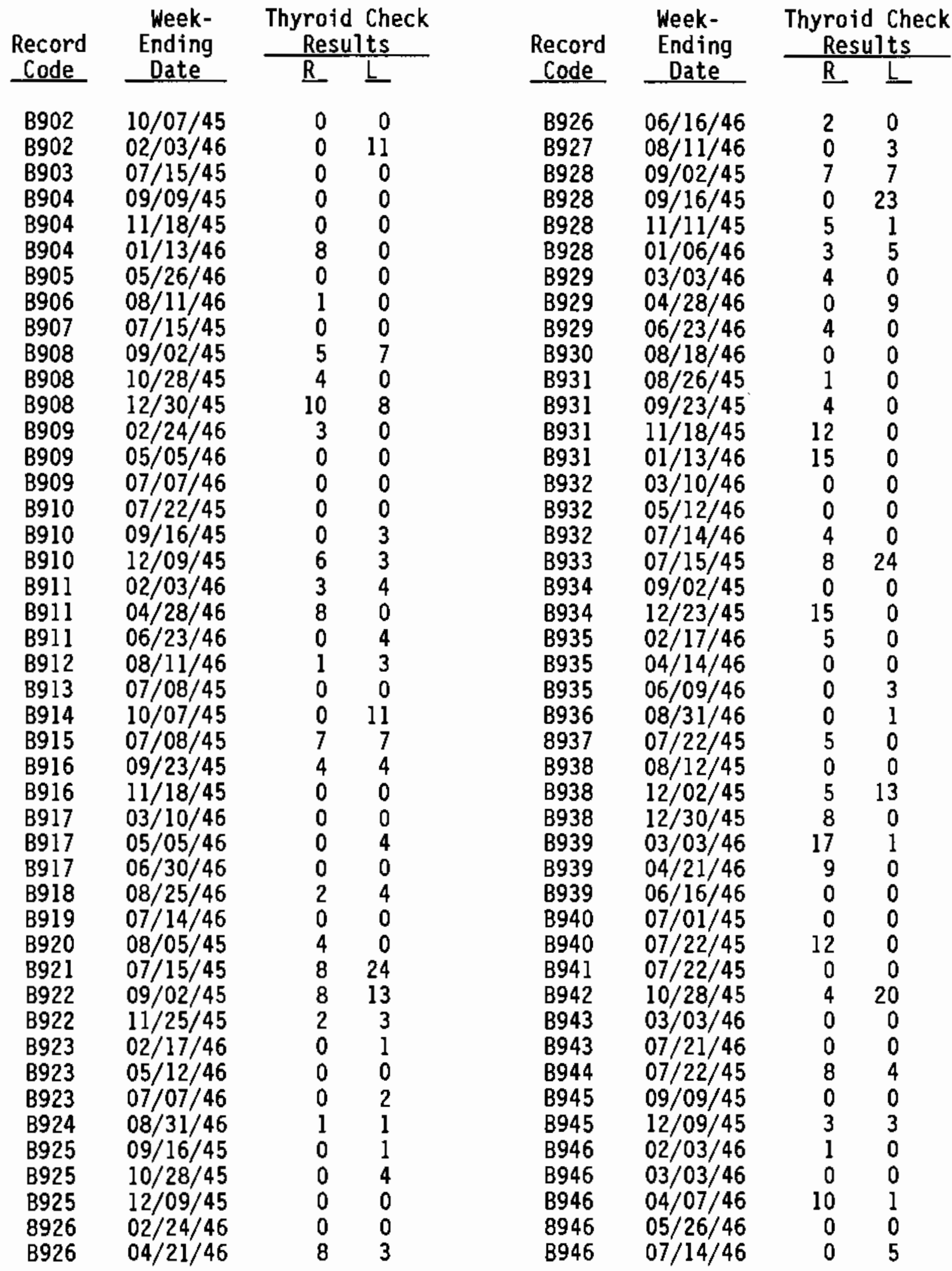


TABLE A.1. (contd)

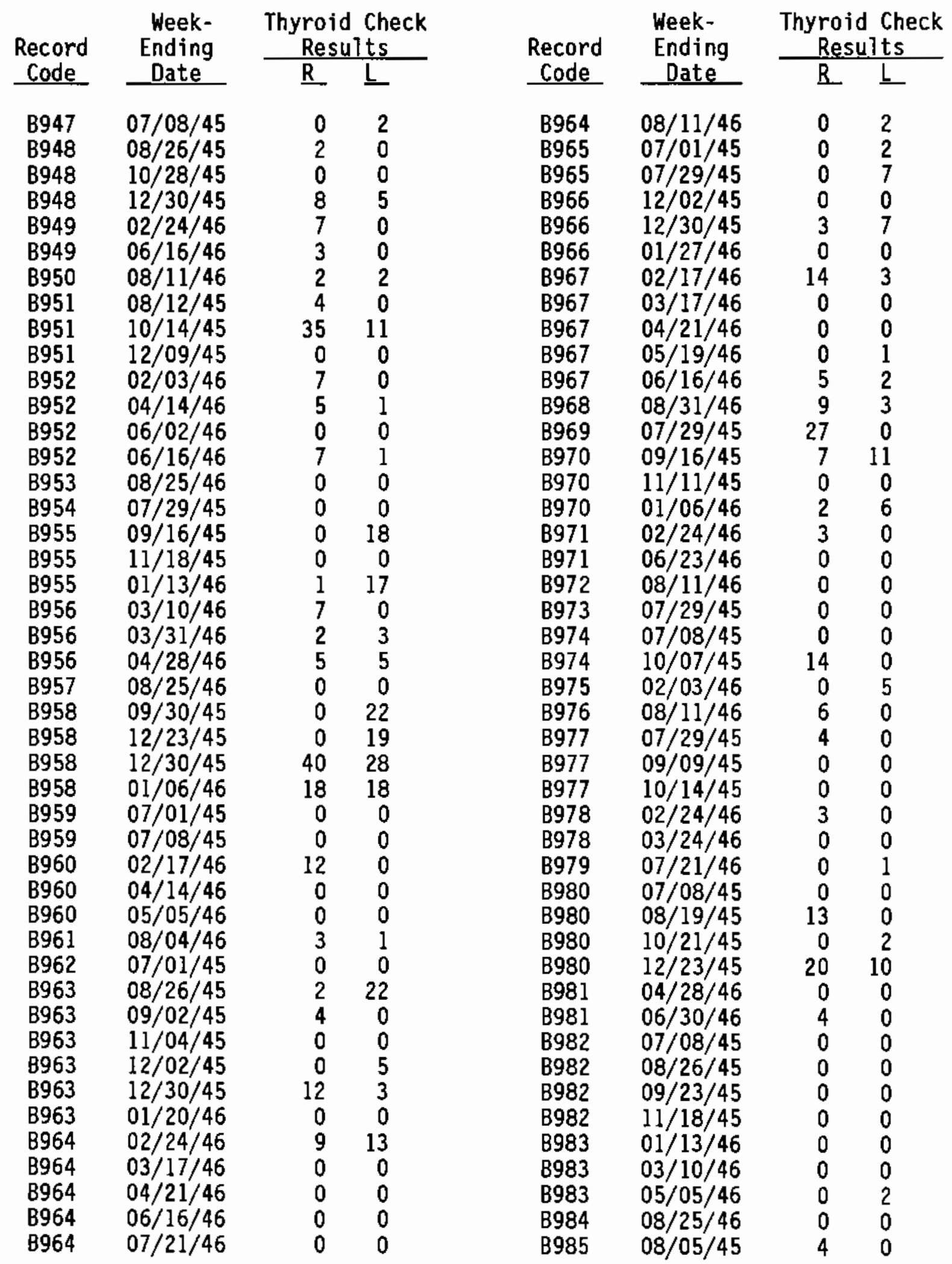


IABLE A.1. (contd)

\begin{tabular}{|c|c|c|c|}
\hline \multirow{2}{*}{$\begin{array}{l}\text { Record } \\
\text { Code }\end{array}$} & \multirow{2}{*}{$\begin{array}{c}\text { Week- } \\
\text { Ending } \\
\text { Date } \\
\end{array}$} & \multicolumn{2}{|c|}{$\begin{array}{l}\text { Thyroid Check } \\
\text { Results }\end{array}$} \\
\hline & & $\underline{R}$ & $L$ \\
\hline B986 & $10 / 07 / 45$ & 0 & 0 \\
\hline B986 & $11 / 25 / 45$ & 0 & 0 \\
\hline B9B6 & $02 / 03 / 46$ & 0 & 0 \\
\hline B987 & $03 / 31 / 46$ & 1 & 0 \\
\hline B987 & $06 / 30 / 46$ & 0 & 1 \\
\hline B987 & $07 / 28 / 46$ & 0 & 0 \\
\hline 8988 & $07 / 22 / 45$ & 0 & 0 \\
\hline B988 & $10 / 07 / 45$ & 0 & 0 \\
\hline B988 & $12 / 02 / 45$ & 9 & $\begin{array}{l}9 \\
2\end{array}$ \\
\hline $\begin{array}{l}\text { B989 } \\
\text { B989 }\end{array}$ & $\begin{array}{l}01 / 27 / 46 \\
03 / 24 / 46\end{array}$ & $\begin{array}{l}0 \\
4\end{array}$ & $\begin{array}{l}3 \\
0\end{array}$ \\
\hline $\mathrm{BgBg}$ & $05 / 19 / 46$ & 0 & 0 \\
\hline B990 & $07 / 14 / 46$ & 0 & 0 \\
\hline B991 & $07 / 15 / 45$ & 0 & 0 \\
\hline $\begin{array}{l}B 991 \\
0001\end{array}$ & $07 / 22 / 45$ & 0 & 0 \\
\hline B991 & $09 / 16 / 45$ & 0 & 2 \\
\hline B992 & $11 / 18 / 45$ & 0 & 1 \\
\hline B992 & $01 / 27 / 46$ & 0 & 9 \\
\hline 8993 & $07 / 29 / 45$ & 18 & 18 \\
\hline B994 & $09 / 16 / 45$ & 0 & 3 \\
\hline B994 & $11 / 11 / 45$ & 0 & 4 \\
\hline B994 & $01 / 06 / 46$ & 4 & 0 \\
\hline B995 & $05 / 05 / 46$ & 0 & 0 \\
\hline B995 & $07 / 07 / 46$ & 0 & 0 \\
\hline B996 & $07 / 15 / 45$ & 3 & 9 \\
\hline $\begin{array}{l}B 996 \\
B 006\end{array}$ & $09 / 09 / 45$ & 0 & $\begin{array}{l}5 \\
0\end{array}$ \\
\hline B996 & $\begin{array}{l}11 / 04 / 45 \\
11 / 25 / 45\end{array}$ & $\begin{array}{l}0 \\
4\end{array}$ & $\begin{array}{l}0 \\
0\end{array}$ \\
\hline B997 & $02 / 24 / 46$ & 0 & 2 \\
\hline B997 & $03 / 24 / 46$ & 2 & 0 \\
\hline B997 & $05 / 12 / 46$ & 0 & 0 \\
\hline $\begin{array}{l}B 998 \\
8999\end{array}$ & $\begin{array}{l}07 / 15 / 45 \\
09 / 30 / 45\end{array}$ & $\begin{array}{l}0 \\
2\end{array}$ & $\begin{array}{l}8 \\
0\end{array}$ \\
\hline $\begin{array}{l}\text { B999 } \\
\text { B }\end{array}$ & $12 / 02 / 45$ & 2 & 5 \\
\hline B999 & $01 / 06 / 46$ & 2 & 6 \\
\hline 81000 & $01 / 27 / 46$ & 0 & 4 \\
\hline & $03 / 24 / 46$ & 0 & 8 \\
\hline & $07 / 14 / 46$ & 6 & 0 \\
\hline & $07 / 15 / 45$ & 26 & 0 \\
\hline & $08 / 26 / 45$ & 6 & 10 \\
\hline & $10 / 28 / 45$ & 4 & 0 \\
\hline & $12 / 23 / 45$ & 0 & 3 \\
\hline & $07 / 01 / 45$ & 4 & 11 \\
\hline & $08 / 19 / 45$ & 11 & 11 \\
\hline & $10 / 14 / 45$ & 15 & 3 \\
\hline
\end{tabular}

\begin{tabular}{|c|c|c|c|}
\hline \multirow{2}{*}{$\begin{array}{l}\text { Record } \\
\text { Code }\end{array}$} & \multirow{2}{*}{$\begin{array}{l}\text { Week- } \\
\text { Ending } \\
\text { Date } \\
\end{array}$} & \multicolumn{2}{|c|}{$\begin{array}{l}\text { Thyroid Check } \\
\text { Results }\end{array}$} \\
\hline & & $\underline{R}$ & \\
\hline B1005 & $02 / 03 / 46$ & 9 & 10 \\
\hline B1005 & $03 / 31 / 46$ & 0 & 0 \\
\hline B1005 & $05 / 26 / 46$ & 0 & 7 \\
\hline B1006 & $07 / 21 / 46$ & 0 & 0 \\
\hline B1007 & $07 / 29 / 45$ & 0 & 10 \\
\hline B1007 & $10 / 28 / 45$ & 0 & 0 \\
\hline B1007 & $12 / 16 / 45$ & 0 & 0 \\
\hline B1008 & $03 / 10 / 46$ & 0 & 0 \\
\hline B1008 & $05 / 19 / 46$ & 0 & 3 \\
\hline B1008 & $07 / 14 / 46$ & 0 & 1 \\
\hline B1009 & $07 / 22 / 45$ & 0 & 5 \\
\hline B1010 & $02 / 24 / 46$ & 7 & 8 \\
\hline B1011 & $07 / 08 / 45$ & 0 & 0 \\
\hline B1011 & $10 / 07 / 45$ & 16 & 24 \\
\hline B1012 & $02 / 10 / 46$ & 0 & 0 \\
\hline B1012 & $05 / 26 / 46$ & 0 & 0 \\
\hline B1013 & $08 / 11 / 46$ & 0 & 6 \\
\hline B1014 & $07 / 01 / 45$ & 0 & 0 \\
\hline B1015 & $08 / 26 / 45$ & 0 & 0 \\
\hline B1015 & $09 / 30 / 45$ & 0 & 0 \\
\hline B1015 & $11 / 25 / 45$ & 0 & 0 \\
\hline B1016 & $02 / 24 / 46$ & 0 & 0 \\
\hline B1016 & $04 / 28 / 46$ & 0 & 0 \\
\hline B1016 & $06 / 23 / 46$ & 6 & 0 \\
\hline B1017 & $06 / 30 / 46$ & 0 & 1 \\
\hline B1018 & $08 / 26 / 45$ & 18 & 0 \\
\hline B1018 & $10 / 28 / 45$ & 0 & 0 \\
\hline B1019 & $07 / 28 / 46$ & 0 & 0 \\
\hline B1020 & $07 / 01 / 45$ & 0 & 5 \\
\hline B1021 & $03 / 24 / 46$ & 0 & 0 \\
\hline B1022 & $08 / 11 / 46$ & 2 & 0 \\
\hline B1023 & $08 / 26 / 45$ & 0 & 22 \\
\hline B1023 & $09 / 23 / 45$ & 12 & 0 \\
\hline $\mathrm{B} 1023$ & $11 / 18 / 45$ & 0 & 0 \\
\hline B1023 & $01 / 13 / 46$ & 0 & 0 \\
\hline B1024 & $03 / 10 / 46$ & 3 & 0 \\
\hline B1024 & $04 / 07 / 46$ & 9 & 3 \\
\hline B1024 & $05 / 05 / 46$ & 2 & 0 \\
\hline Blo24 & $06 / 30 / 46$ & 1 & 0 \\
\hline B1025 & $08 / 25 / 46$ & 4 & 3 \\
\hline B1026 & $07 / 15 / 45$ & 18 & 0 \\
\hline 1027 & $08 / 26 / 45$ & 0 & 0 \\
\hline 027 & $11 / 04 / 45$ & 7 & 3 \\
\hline 1027 & $01 / 13 / 46$ & 26 & 10 \\
\hline 1028 & $07 / 15 / 45$ & 14 & 14 \\
\hline
\end{tabular}


IABLE A.1. (contd)

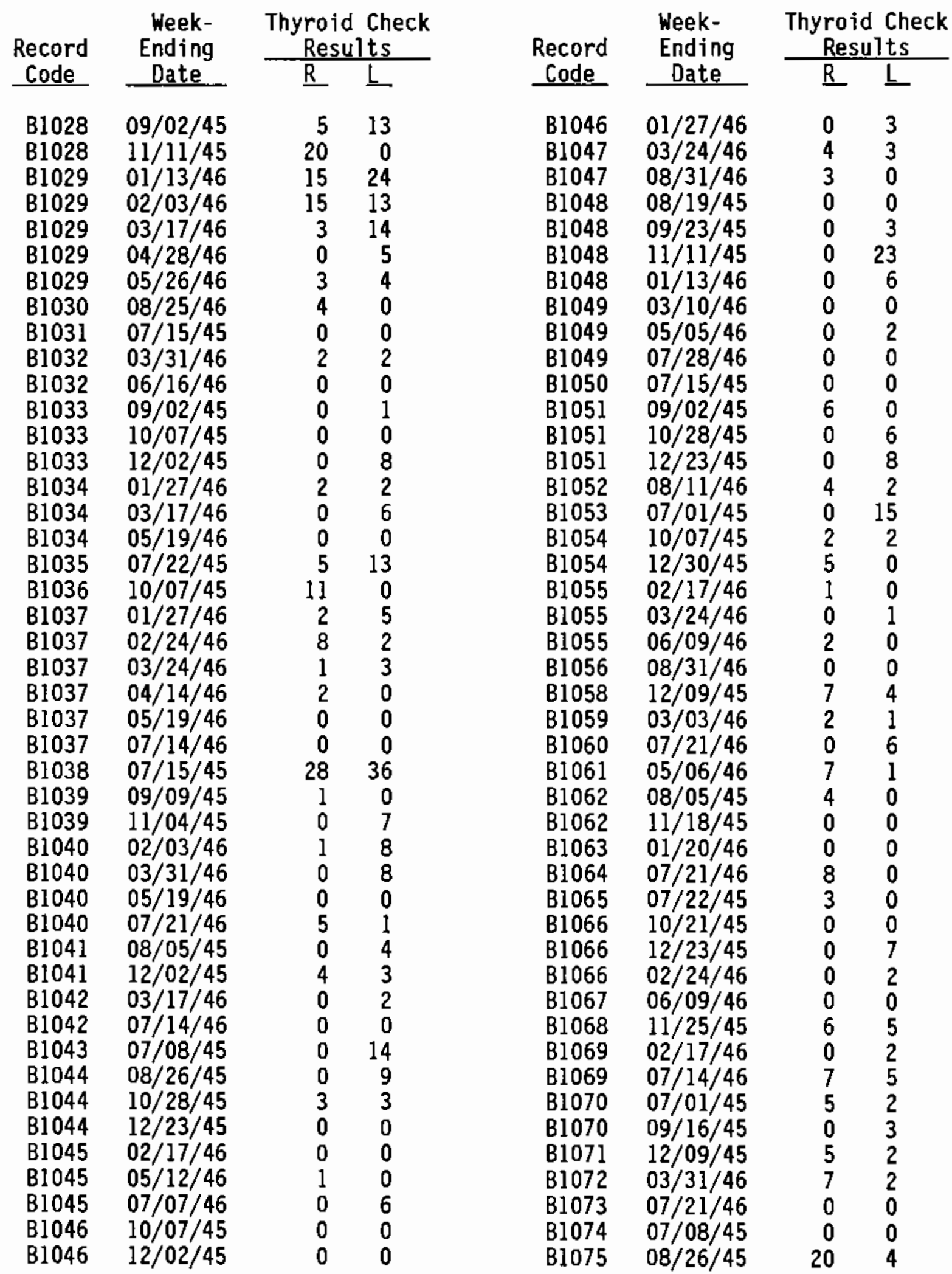


IABLE A.1. (contd)

\begin{tabular}{|c|c|c|c|c|c|c|c|}
\hline \multirow{2}{*}{$\begin{array}{l}\text { Record } \\
\text { Code }\end{array}$} & $\begin{array}{l}\text { Week- } \\
\text { Ending }\end{array}$ & \multicolumn{2}{|c|}{$\begin{array}{c}\text { Thyroid Check } \\
\text { Results }\end{array}$} & \multirow{2}{*}{$\begin{array}{l}\text { Record } \\
\text { Code } \\
\end{array}$} & \multirow{2}{*}{$\begin{array}{c}\text { Week- } \\
\text { Ending } \\
\text { Date }\end{array}$} & \multicolumn{2}{|c|}{$\begin{array}{l}\text { Thyroid Check } \\
\text { Results } \\
\end{array}$} \\
\hline & Date & $\underline{\mathrm{R}}$ & $\underline{L}$ & & & $\underline{R}$ & $\underline{\mathrm{L}}$ \\
\hline B1075 & $10 / 07 / 45$ & 0 & 0 & B1096 & $06 / 30 / 46$ & 0 & 0 \\
\hline B1075 & $12 / 02 / 45$ & 0 & 0 & B 1097 & $08 / 18 / 46$ & 4 & 0 \\
\hline B1076 & $01 / 27 / 46$ & 2 & 1 & Bl098 & $07 / 08 / 45$ & 10 & 10 \\
\hline B1076 & $03 / 24 / 46$ & 0 & 0 & Blog9 & $02 / 10 / 46$ & 10 & 8 \\
\hline B1077 & $07 / 15 / 45$ & 0 & 24 & B1 100 & $05 / 26 / 46$ & 0 & 0 \\
\hline B1077 & $10 / 28 / 45$ & 8 & 4 & B1100 & $07 / 28 / 46$ & 0 & 0 \\
\hline B1077 & $12 / 09 / 45$ & 5 & 4 & $\mathrm{Bl101}$ & $07 / 15 / 45$ & 6 & 0 \\
\hline B1078 & $02 / 17 / 46$ & 0 & 0 & B1101 & $10 / 28 / 45$ & 23 & 3 \\
\hline B107B & $04 / 14 / 46$ & 0 & 4 & B1101 & $12 / 23 / 45$ & 23 & 3 \\
\hline B1079 & $07 / 14 / 46$ & 1 & 0 & B1102 & $03 / 17 / 46$ & 0 & 0 \\
\hline B1080 & $07 / 28 / 46$ & 0 & 2 & B1102 & $05 / 12 / 46$ & 0 & 4 \\
\hline $\mathrm{B} 1081$ & $01 / 13 / 46$ & 7 & 4 & B] 103 & $08 / 04 / 46$ & 5 & 6 \\
\hline B1081 & $03 / 10 / 46$ & 6 & 0 & B1104 & $07 / 01 / 45$ & 8 & 0 \\
\hline B1081 & $06 / 02 / 46$ & 5 & 0 & B1105 & $08 / 19 / 45$ & 0 & 0 \\
\hline B1082 & $08 / 26 / 45$ & 1 & 9 & BI105 & $10 / 28 / 45$ & 0 & 0 \\
\hline $\mathrm{BlOB} 2$ & $11 / 18 / 45$ & 11 & 0 & B1105 & $12 / 23 / 45$ & 0 & 0 \\
\hline B1083 & $07 / 15 / 45$ & 0 & 0 & B1106 & $02 / 17 / 46$ & 0 & 0 \\
\hline B1083 & $09 / 02 / 45$ & 0 & 0 & B1106 & $04 / 14 / 46$ & 2 & 4 \\
\hline B1083 & $09 / 30 / 45$ & 0 & 0 & B1106 & $05 / 12 / 46$ & 0 & 0 \\
\hline B1083 & $11 / 25 / 45$ & 0 & 0 & B1106 & $06 / 09 / 46$ & 0 & 0 \\
\hline B1084 & $02 / 24 / 46$ & 4 & 10 & B1107 & $08 / 04 / 46$ & 0 & 3 \\
\hline B1084 & $04 / 28 / 46$ & 0 & 0 & B1107 & $08 / 25 / 46$ & 0 & 3 \\
\hline B1085 & $10 / 21 / 45$ & 6 & 0 & B1108 & $04 / 21 / 46$ & 0 & 0 \\
\hline B1085 & $12 / 23 / 45$ & 0 & 0 & B1108 & $05 / 12 / 46$ & 0 & 0 \\
\hline Blo86 & $02 / 17 / 46$ & 0 & 0 & B1 108 & $06 / 16 / 46$ & 0 & 4 \\
\hline B1086 & $04 / 21 / 46$ & 0 & 0 & Bl 109 & $08 / 11 / 46$ & 6 & 1 \\
\hline B1086 & $06 / 23 / 46$ & 0 & 0 & B 1110 & $07 / 01 / 45$ & 0 & 0 \\
\hline B1087 & $08 / 25 / 46$ & 0 & 0 & BIIII & $08 / 26 / 45$ & 0 & 8 \\
\hline B1088 & $12 / 09 / 45$ & 6 & 8 & B1111 & $11 / 11 / 45$ & 16 & 8 \\
\hline B1088 & $12 / 30 / 45$ & 0 & 0 & B1112 & $03 / 03 / 46$ & 9 & 4 \\
\hline $\mathrm{Bl} 089$ & $03 / 03 / 46$ & 0 & 0 & B1112 & $04 / 28 / 46$ & 0 & 0 \\
\hline B1089 & $03 / 31 / 46$ & 0 & 0 & B1112 & $06 / 23 / 46$ & 0 & 7 \\
\hline B1089 & $04 / 21 / 46$ & 0 & 0 & Bl113 & $07 / 08 / 45$ & 0 & 0 \\
\hline B1090 & $08 / 18 / 46$ & 0 & 0 & B1114 & $09 / 09 / 45$ & 0 & 0 \\
\hline B1091 & $06 / 24 / 45$ & 3 & 15 & B1114 & $11 / 25 / 45$ & 0 & 8 \\
\hline B1091 & $07 / 01 / 45$ & 10 & 0 & B1115 & $02 / 17 / 46$ & 2 & 5 \\
\hline B1092 & $08 / 26 / 45$ & 0 & 0 & B1115 & $04 / 14 / 46$ & 0 & 0 \\
\hline B1092 & $10 / 21 / 45$ & 3 & 3 & B1115 & $05 / 12 / 46$ & 0 & 0 \\
\hline B1092 & $12 / 09 / 45$ & 1 & 9 & B1115 & $06 / 09 / 46$ & 0 & 0 \\
\hline B1093 & $07 / 21 / 46$ & 0 & 0 & Bl116 & $08 / 04 / 46$ & 2 & 0 \\
\hline B1095 & $08 / 26 / 45$ & 0 & 3 & B1117 & $07 / 15 / 45$ & 6 & 0 \\
\hline B1095 & $10 / 21 / 45$ & 0 & 1 & B1117 & $10 / 07 / 45$ & 0 & 10 \\
\hline Bl095 & $12 / 23 / 45$ & 0 & 8 & B1117 & $12 / 02 / 45$ & 0 & 0 \\
\hline B109 & $02 / 24 / 46$ & 0 & 0 & B1118 & $01 / 27 / 46$ & 0 & 0 \\
\hline B1096 & $06 / 09 / 46$ & 4 & 0 & B1118 & $03 / 24 / 46$ & 1 & 2 \\
\hline
\end{tabular}


TABLE A.1. (contd)

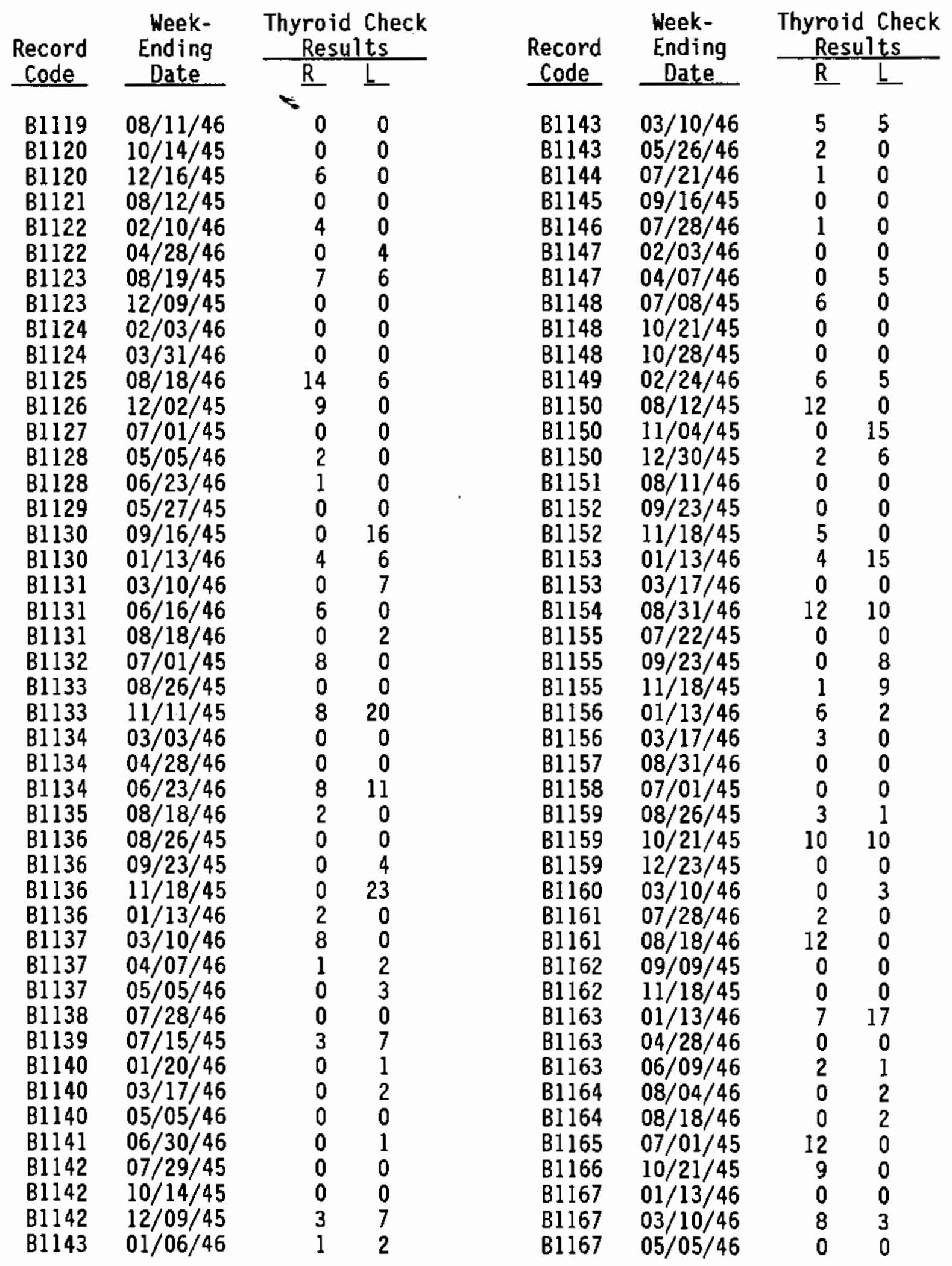


IABLE A.1. (contd)

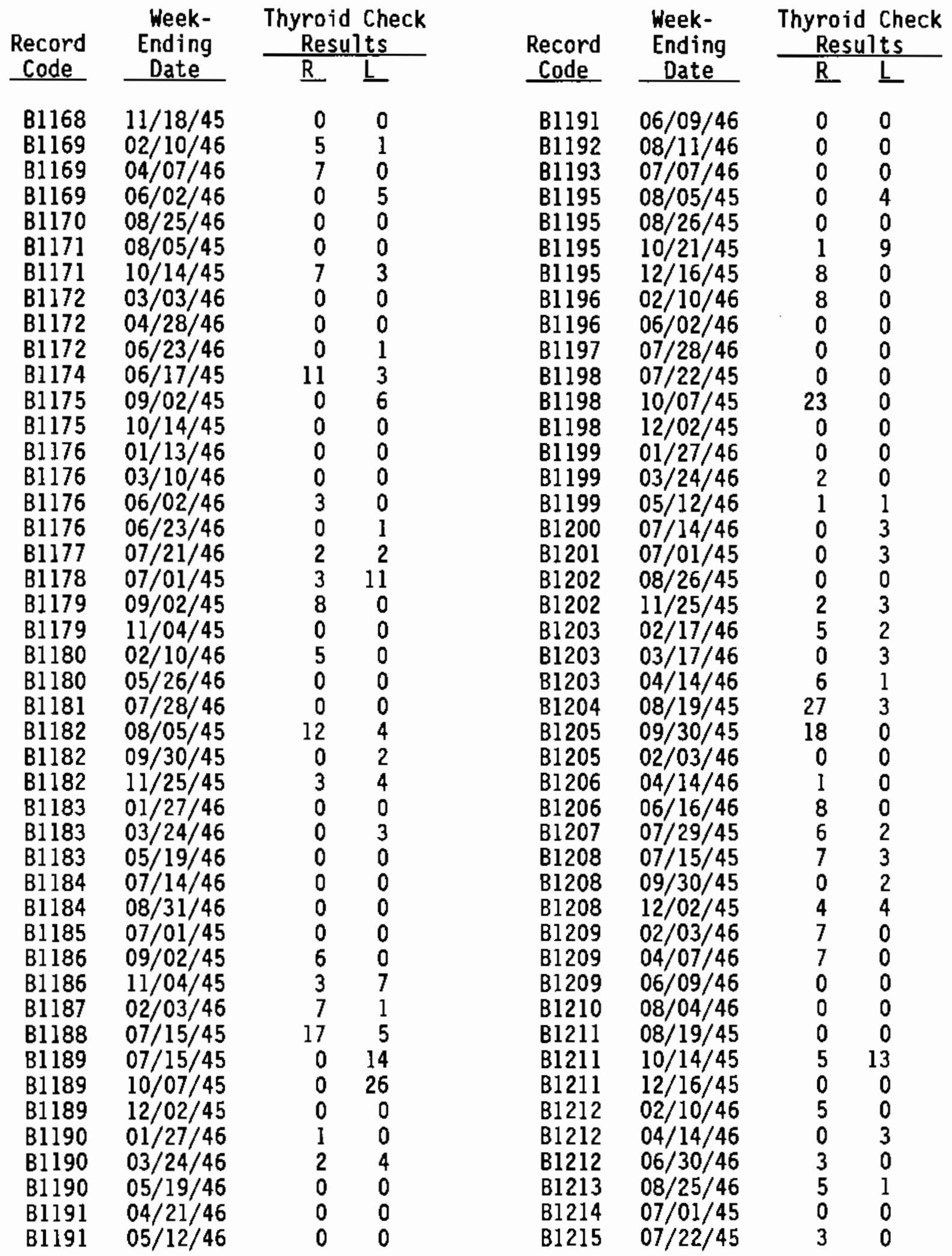


IABLE A.1. (contd)

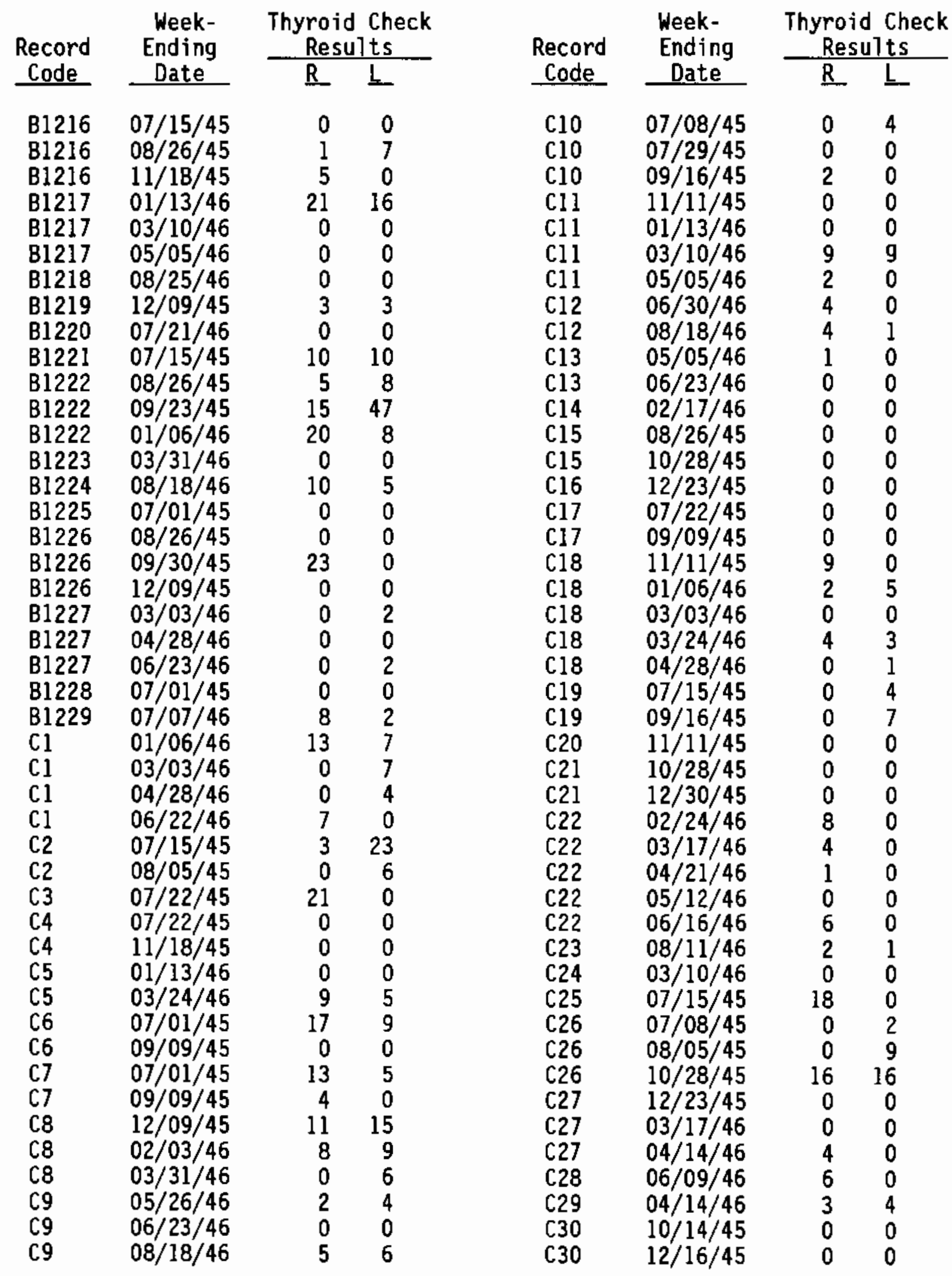


IABLE A.1. (contd)

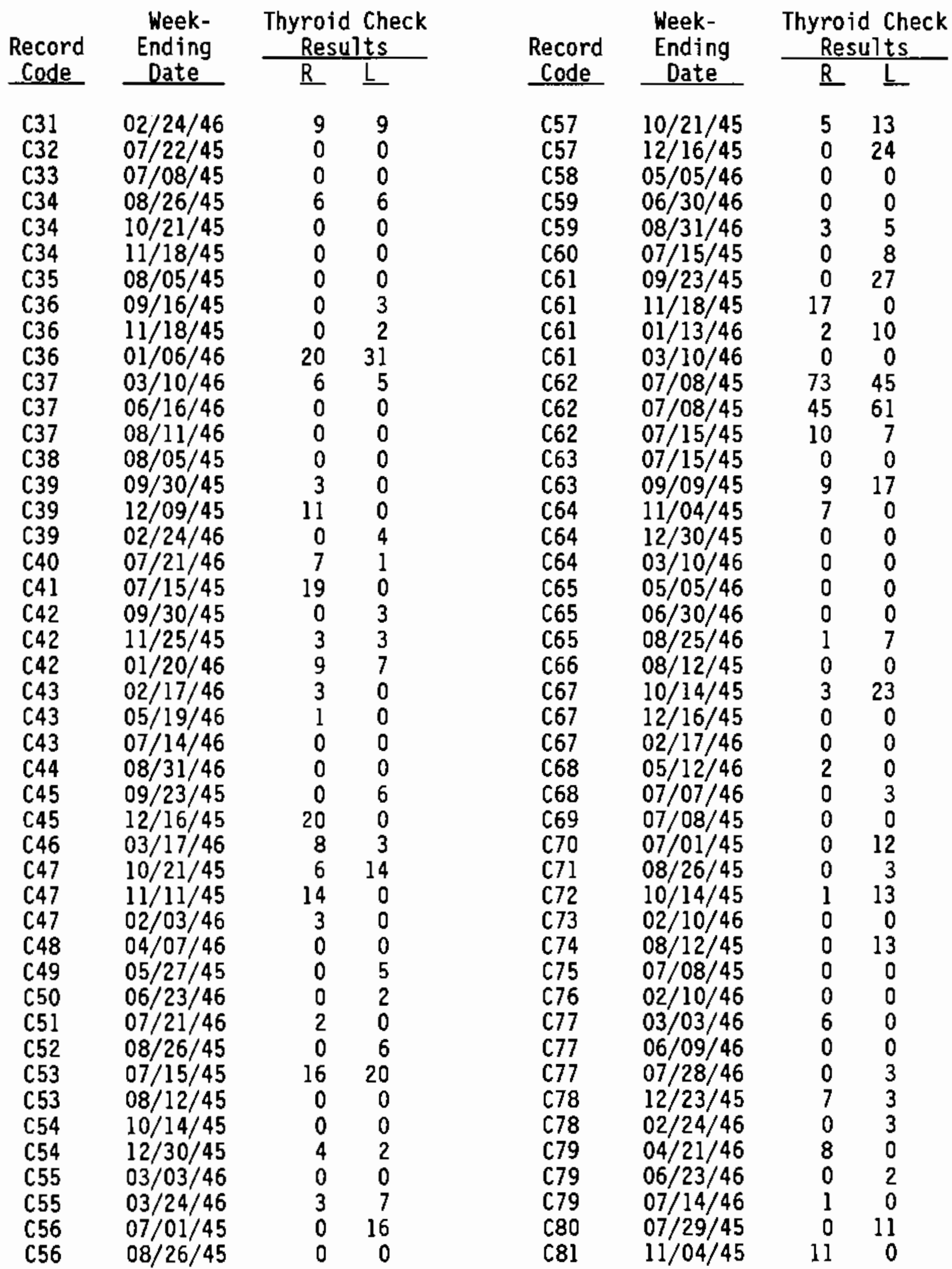


IABLE A.1. (contd)

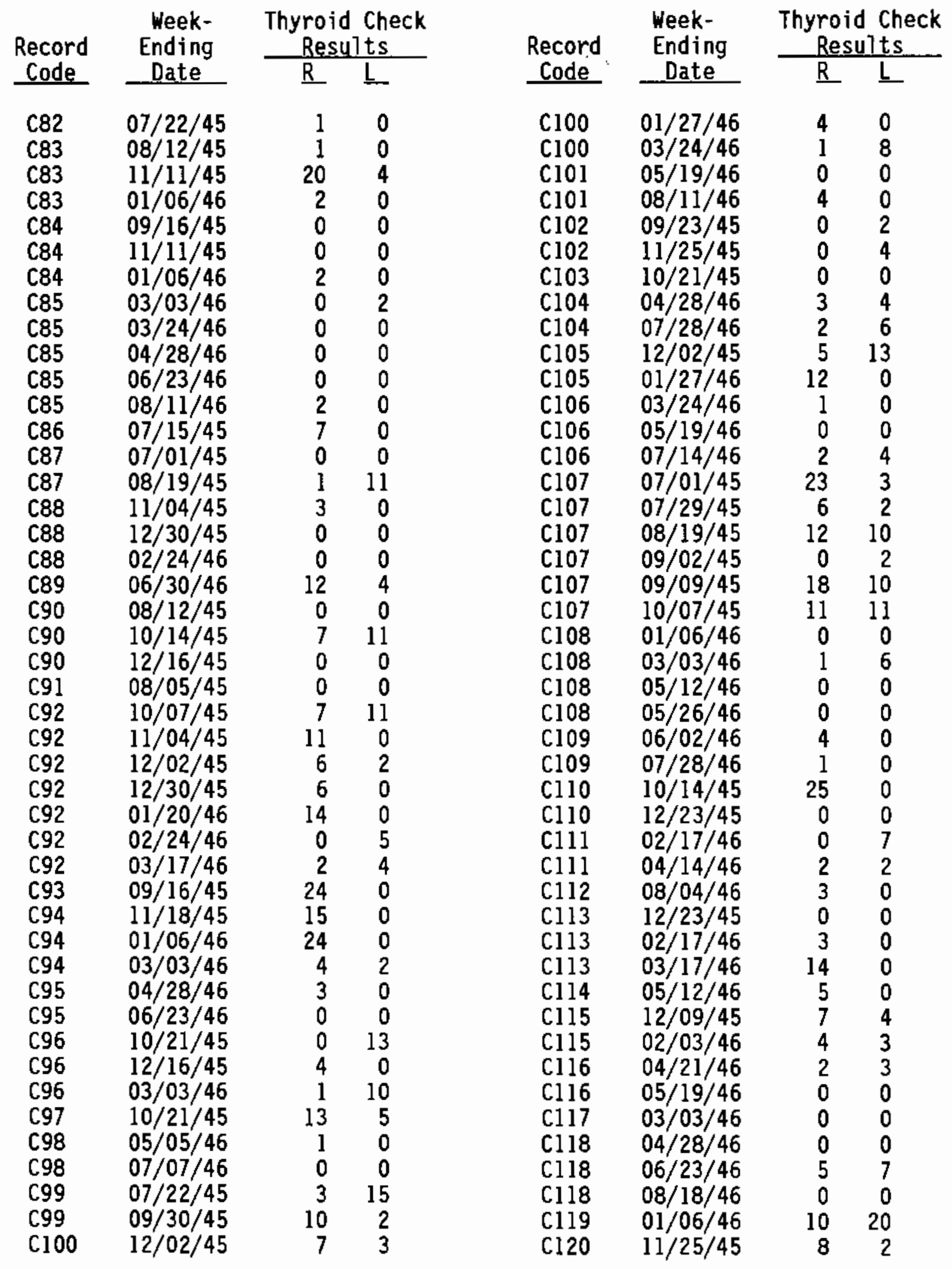


TABLE A.1. (contd)

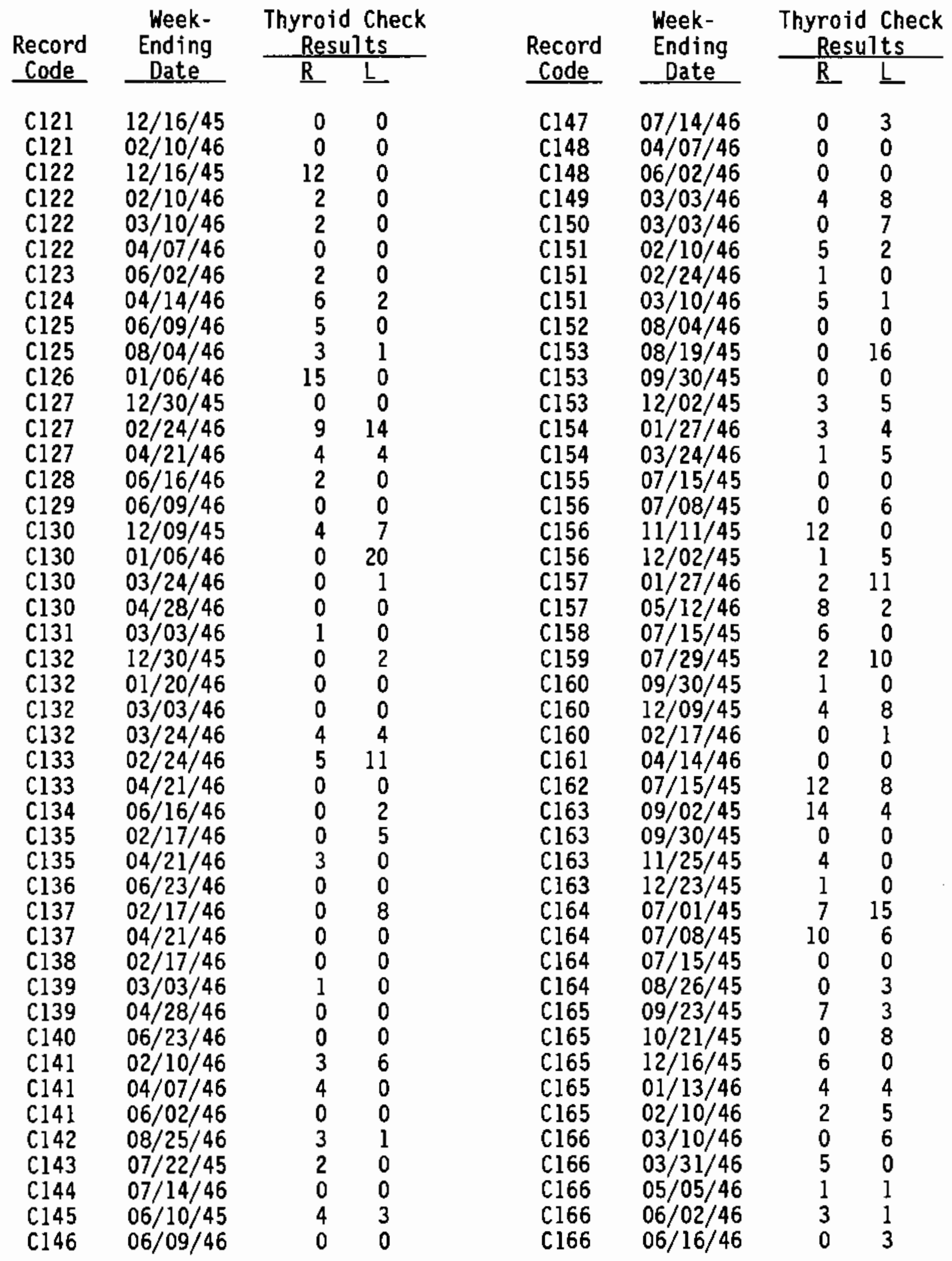


IABLE A.1. (contd)

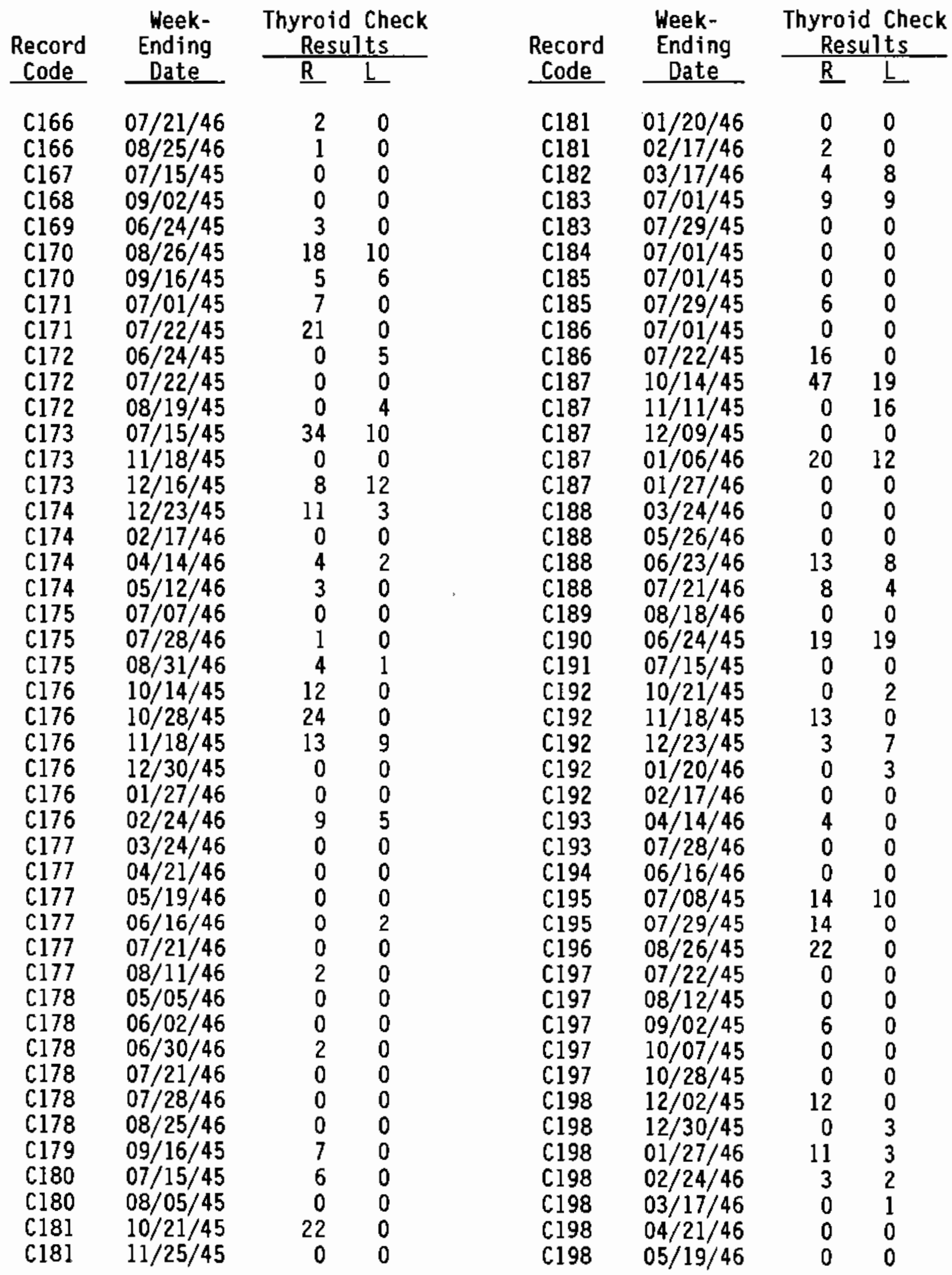


TABLE A.1. (contd)

\begin{tabular}{|c|c|c|c|c|c|c|c|}
\hline \multirow{2}{*}{$\begin{array}{l}\text { Record } \\
\text { Code }\end{array}$} & \multirow{2}{*}{$\begin{array}{c}\text { Week- } \\
\text { Ending } \\
\text { Date } \\
\end{array}$} & \multicolumn{2}{|c|}{$\begin{array}{l}\text { Thyroid Check } \\
\text { Results }\end{array}$} & \multirow{2}{*}{$\begin{array}{l}\text { Record } \\
\text { Code }\end{array}$} & \multirow{2}{*}{$\begin{array}{l}\text { Week- } \\
\text { Ending } \\
\text { Date } \\
\end{array}$} & \multicolumn{2}{|c|}{$\begin{array}{l}\text { Thyroid Check } \\
\text { Results }\end{array}$} \\
\hline & & $\underline{\mathrm{R}}$ & $\underline{L}$ & & & $\underline{R}$ & $L$ \\
\hline C199 & $06 / 16 / 46$ & 0 & 0 & $\mathrm{C} 212$ & $03 / 03 / 46$ & 0 & 0 \\
\hline C199 & $08 / 04 / 46$ & 0 & 6 & C212 & $03 / 31 / 46$ & 10 & 7 \\
\hline $\mathrm{C} 200$ & $07 / 15 / 45$ & 6 & 2 & C212 & $04 / 07 / 46$ & 1 & 0 \\
\hline $\mathrm{C} 200$ & $10 / 21 / 45$ & 10 & 10 & $\mathrm{C} 212$ & $04 / 14 / 46$ & 5 & 1 \\
\hline $\mathrm{C} 200$ & $11 / 18 / 45$ & 0 & 0 & $\mathrm{C} 212$ & $05 / 26 / 46$ & 2 & 2 \\
\hline C201 & $01 / 20 / 46$ & 3 & 5 & C213 & $06 / 23 / 46$ & 0 & 1 \\
\hline C201 & $02 / 17 / 46$ & 10 & 1 & C213 & $07 / 21 / 46$ & 0 & 0 \\
\hline C201 & $04 / 14 / 46$ & 2 & 8 & C213 & $08 / 18 / 46$ & 4 & 0 \\
\hline C201 & $05 / 12 / 46$ & 3 & 4 & C214 & $07 / 01 / 45$ & 0 & 0 \\
\hline C202 & $07 / 22 / 45$ & 9 & 0 & C214 & $08 / 05 / 45$ & 15 & 7 \\
\hline C203 & $07 / 15 / 45$ & 0 & 0 & C214 & $10 / 07 / 45$ & 10 & 0 \\
\hline C204 & $10 / 21 / 45$ & 0 & 14 & C215 & $12 / 16 / 45$ & 0 & 0 \\
\hline C204 & $11 / 18 / 45$ & 0 & 0 & $\mathrm{C} 215$ & $12 / 30 / 45$ & 2 & 0 \\
\hline C204 & $12 / 23 / 45$ & 8 & 20 & C215 & $03 / 10 / 46$ & 3 & 9 \\
\hline C204 & $12 / 23 / 45$ & 11 & 0 & C215 & $03 / 17 / 46$ & 2 & 0 \\
\hline C204 & $01 / 20 / 46$ & 0 & 0 & $\mathrm{C} 215$ & $03 / 31 / 46$ & 0 & 4 \\
\hline C204 & $02 / 17 / 46$ & 10 & 11 & $\mathrm{C} 215$ & $04 / 07 / 46$ & 1 & 0 \\
\hline$C 205$ & $03 / 10 / 46$ & 2 & 6 & C215 & $05 / 05 / 46$ & 0 & 2 \\
\hline C205 & $04 / 14 / 46$ & 0 & 5 . & C216 & $06 / 23 / 46$ & 1 & 0 \\
\hline $\mathrm{C} 206$ & $07 / 15 / 45$ & 11 & 3 & C216 & $07 / 28 / 46$ & 0 & 0 \\
\hline C207 & $09 / 02 / 45$ & 2 & 12 & C216 & $08 / 18 / 46$ & 0 & 0 \\
\hline C208 & $07 / 22 / 45$ & 0 & 0 & C217 & $07 / 08 / 45$ & 20 & 0 \\
\hline $\mathrm{C} 208$ & $08 / 12 / 45$ & 0 & 0 & C217 & $08 / 05 / 45$ & 0 & 4 \\
\hline C208 & $09 / 02 / 45$ & 21 & 0 & C217 & $09 / 23 / 45$ & 7 & 0 \\
\hline C208 & $09 / 23 / 45$ & 15 & 11 & C217 & $10 / 14 / 45$ & 0 & 16 \\
\hline C208 & $10 / 14 / 45$ & 7 & 15 & C217 & $11 / 11 / 45$ & 0 & 0 \\
\hline C208 & $10 / 21 / 45$ & 0 & 8 & C218 & $12 / 09 / 45$ & 21 & 0 \\
\hline C208 & $11 / 11 / 45$ & 0 & 7 & C218 & $01 / 13 / 46$ & 0 & 3 \\
\hline C209 & $12 / 23 / 45$ & 9 & 7 & C218 & $03 / 03 / 46$ & 0 & 5 \\
\hline C209 & $01 / 20 / 46$ & 12 & 11 & C218 & $04 / 07 / 46$ & 3 & 0 \\
\hline C209 & $02 / 17 / 46$ & 3 & 4 & C218 & $05 / 05 / 46$ & 0 & 0 \\
\hline C209 & $03 / 17 / 46$ & 4 & 0 & $\mathrm{C} 218$ & $05 / 26 / 46$ & 4 & 0 \\
\hline C209 & $04 / 07 / 46$ & 8 & 2 & C219 & $06 / 02 / 46$ & 0 & 0 \\
\hline C209 & $05 / 12 / 46$ & 0 & 8 & C219 & $06 / 23 / 46$ & 0 & 0 \\
\hline C210 & $06 / 16 / 46$ & 2 & 0 & C219 & $07 / 28 / 46$ & 0 & 0 \\
\hline C210 & $07 / 14 / 46$ & 0 & 4 & C219 & $08 / 25 / 46$ & 0 & 0 \\
\hline C210 & $08 / 31 / 46$ & 0 & 0 & C220 & $07 / 08 / 45$ & 0 & 0 \\
\hline C211 & $07 / 15 / 45$ & 4 & 0 & C220 & $08 / 05 / 45$ & 0 & 0 \\
\hline C211 & $09 / 23 / 45$ & 0 & 0 & $\mathrm{C} 220$ & $08 / 26 / 45$ & 23 & 3 \\
\hline C211 & $10 / 07 / 45$ & 7 & 10 & C220 & $09 / 23 / 45$ & 11 & 11 \\
\hline C211 & $11 / 18 / 45$ & 13 & 0 & $\mathrm{C} 220$ & $10 / 14 / 45$ & 0 & 4 \\
\hline C212 & $12 / 09 / 45$ & 1 & 4 & C220 & $11 / 18 / 45$ & 0 & 0 \\
\hline C212 & $12 / 16 / 45$ & 0 & 0 & C221 & $12 / 16 / 45$ & 8 & 4 \\
\hline C212 & $01 / 06 / 46$ & 12 & 8 & C221 & $01 / 13 / 46$ & 0 & 0 \\
\hline C212 & $02 / 03 / 46$ & 1 & 0 & C221 & $02 / 10 / 46$ & 0 & 0 \\
\hline
\end{tabular}


TABLE A.1. (contd)

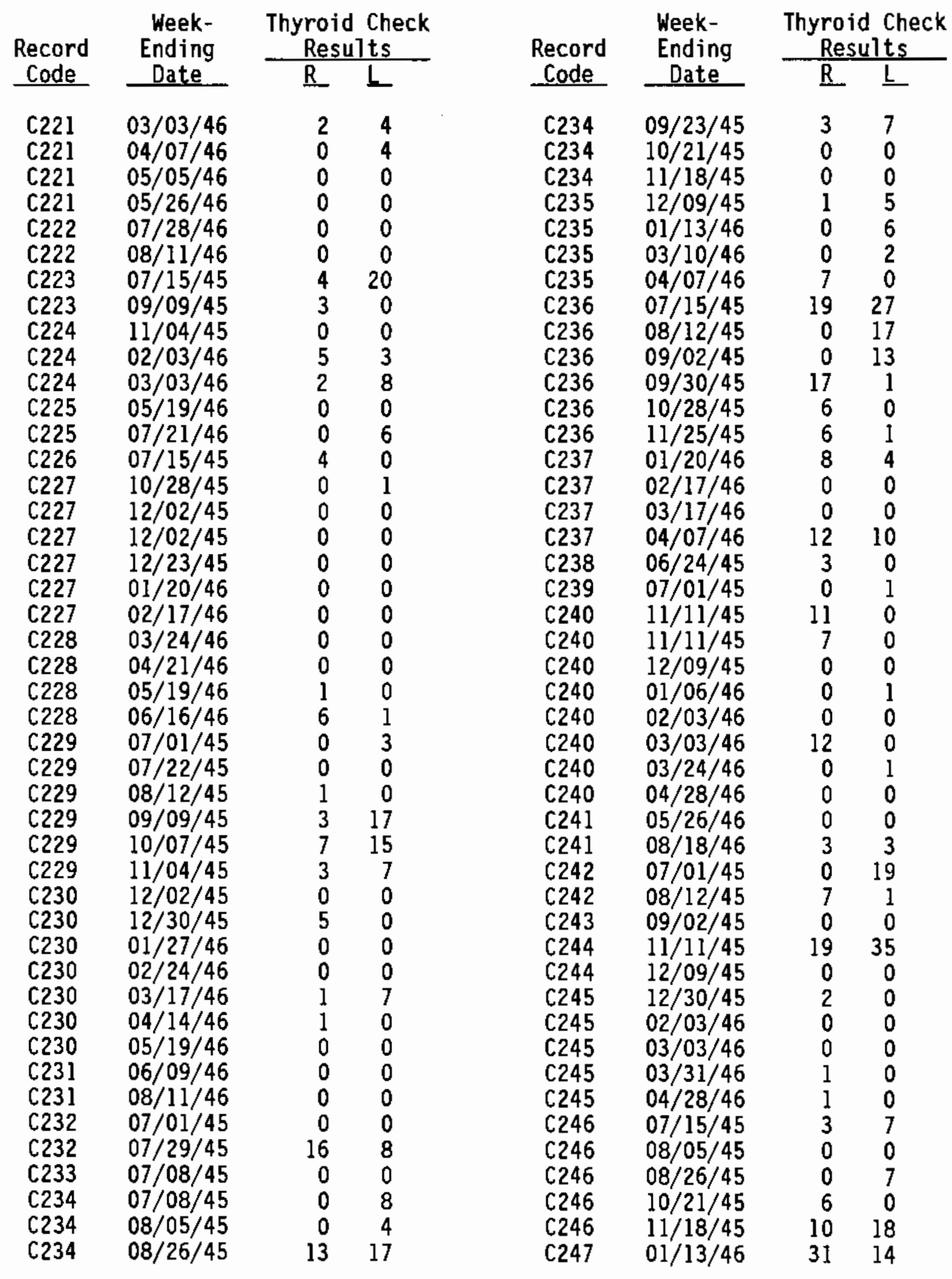


IABLE A.1. (contd)

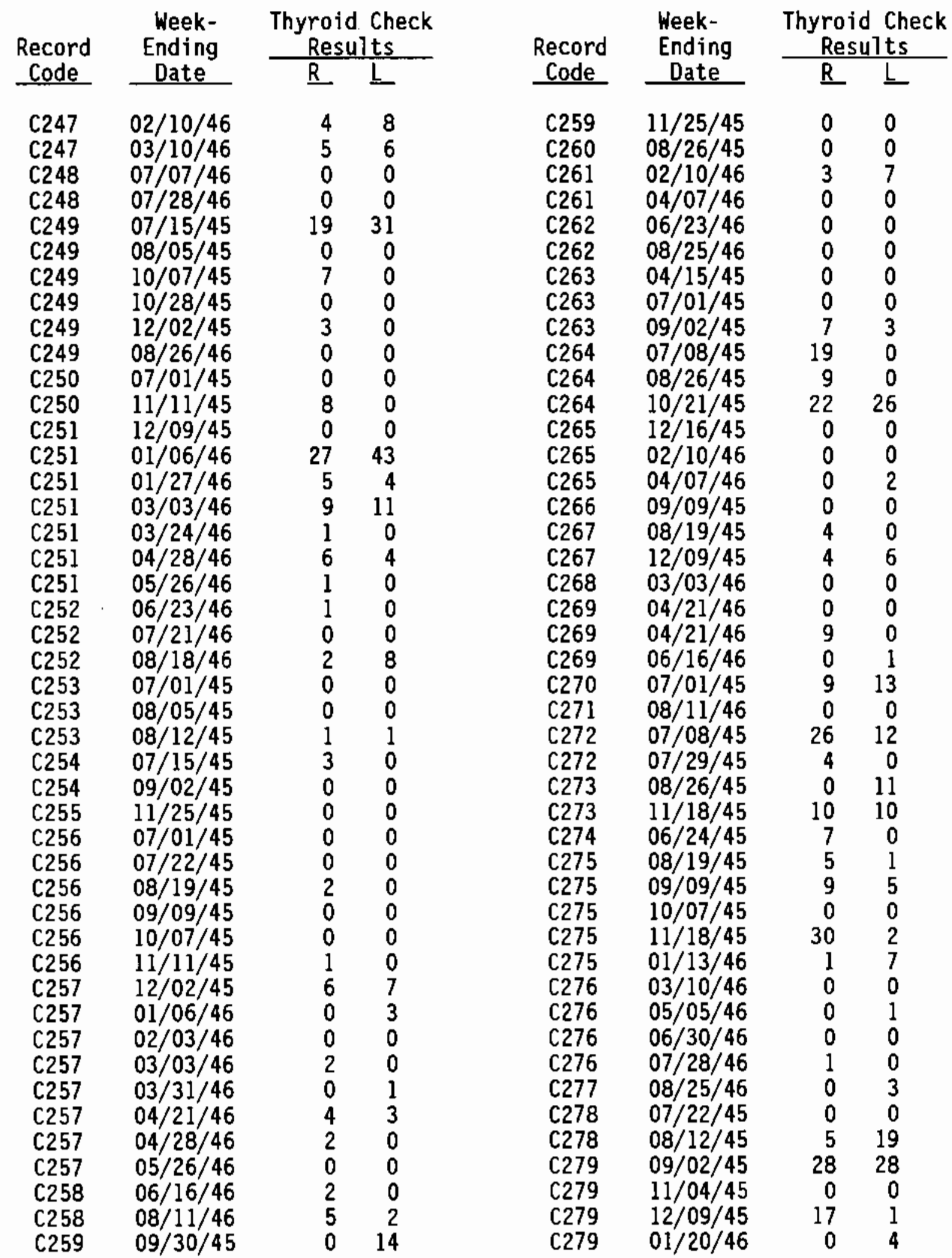


IABLE A.1. (contd)

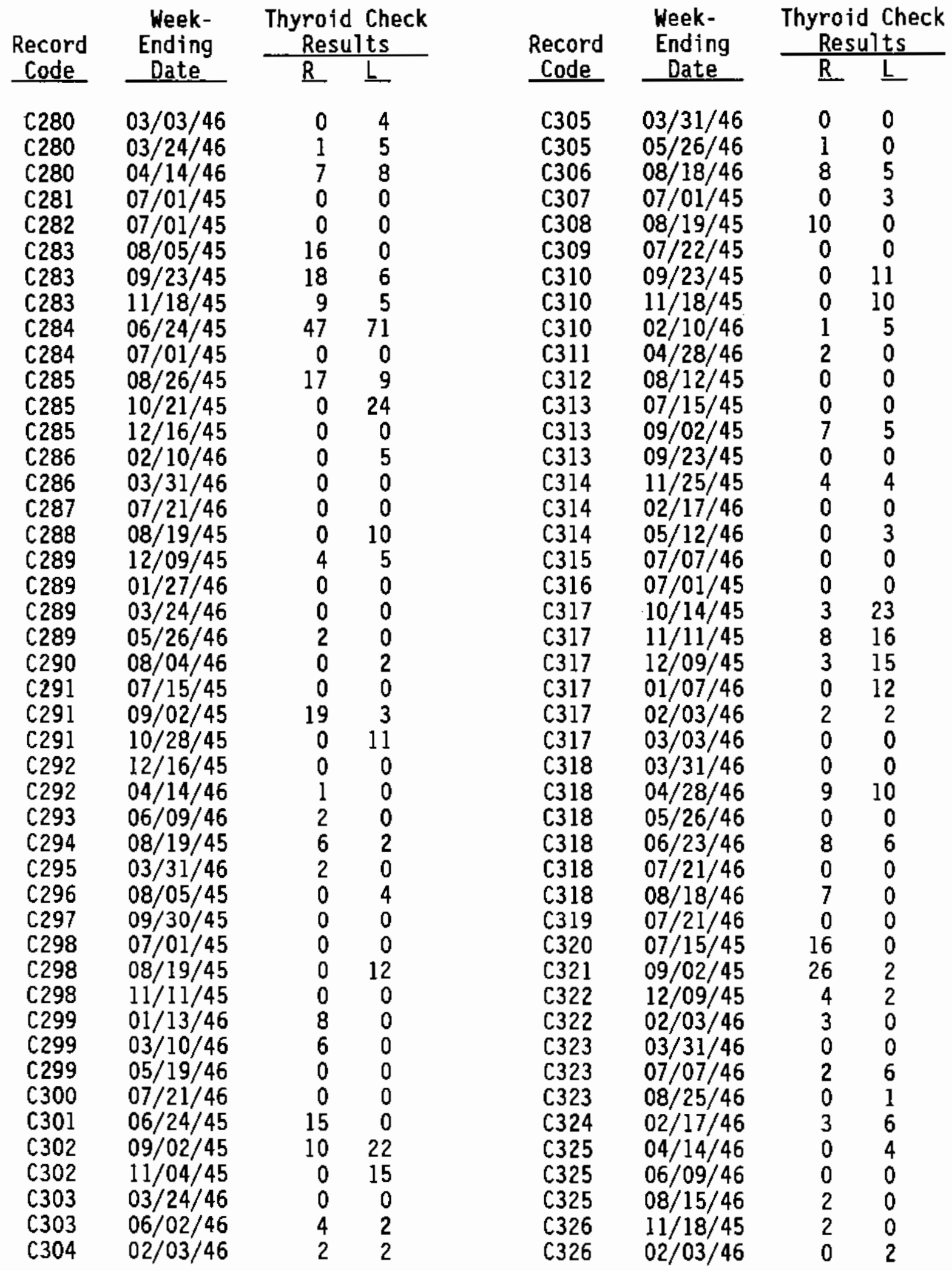


IABLE A.1. (contd)

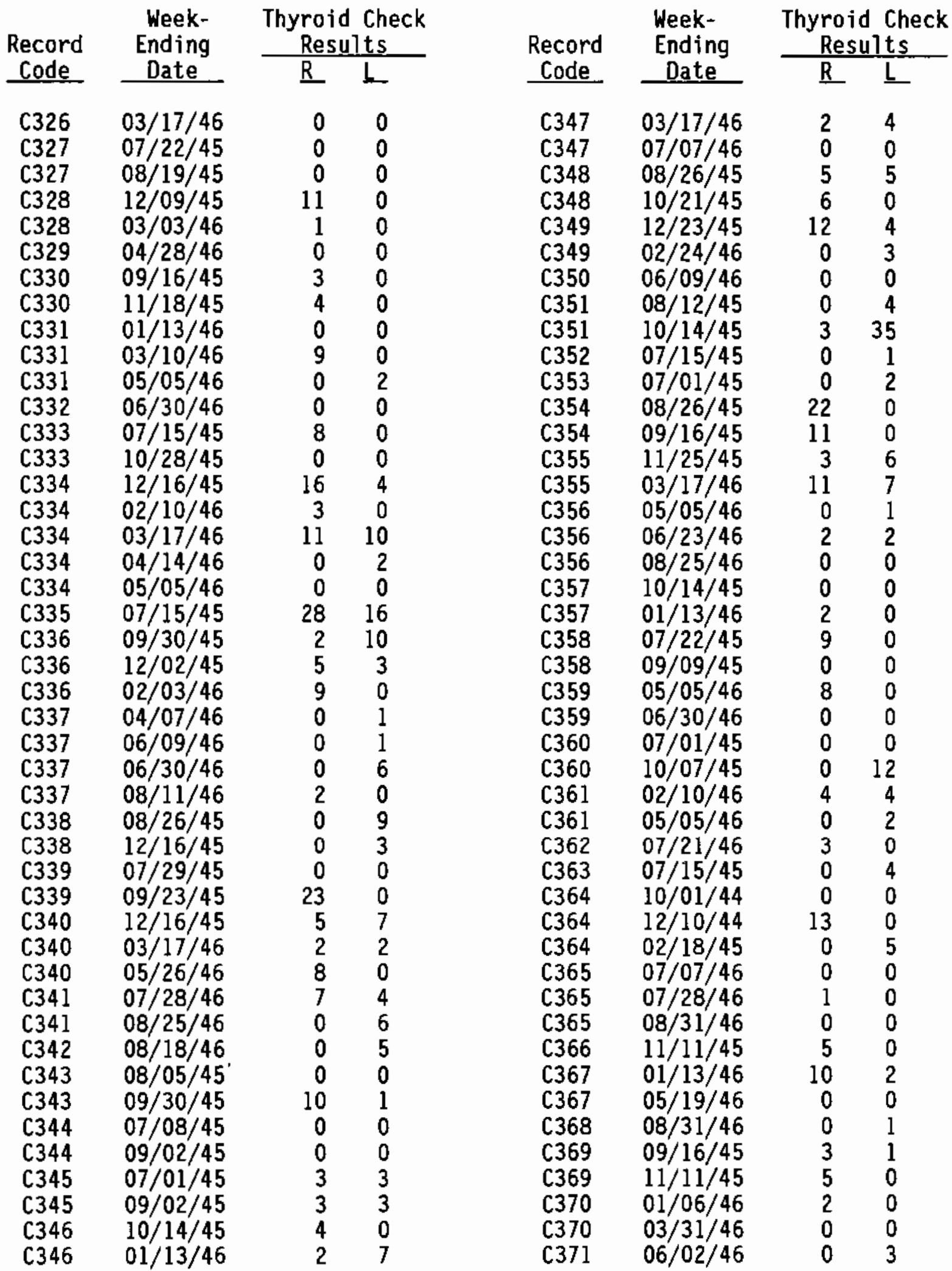


TABLE A.1. (contd)

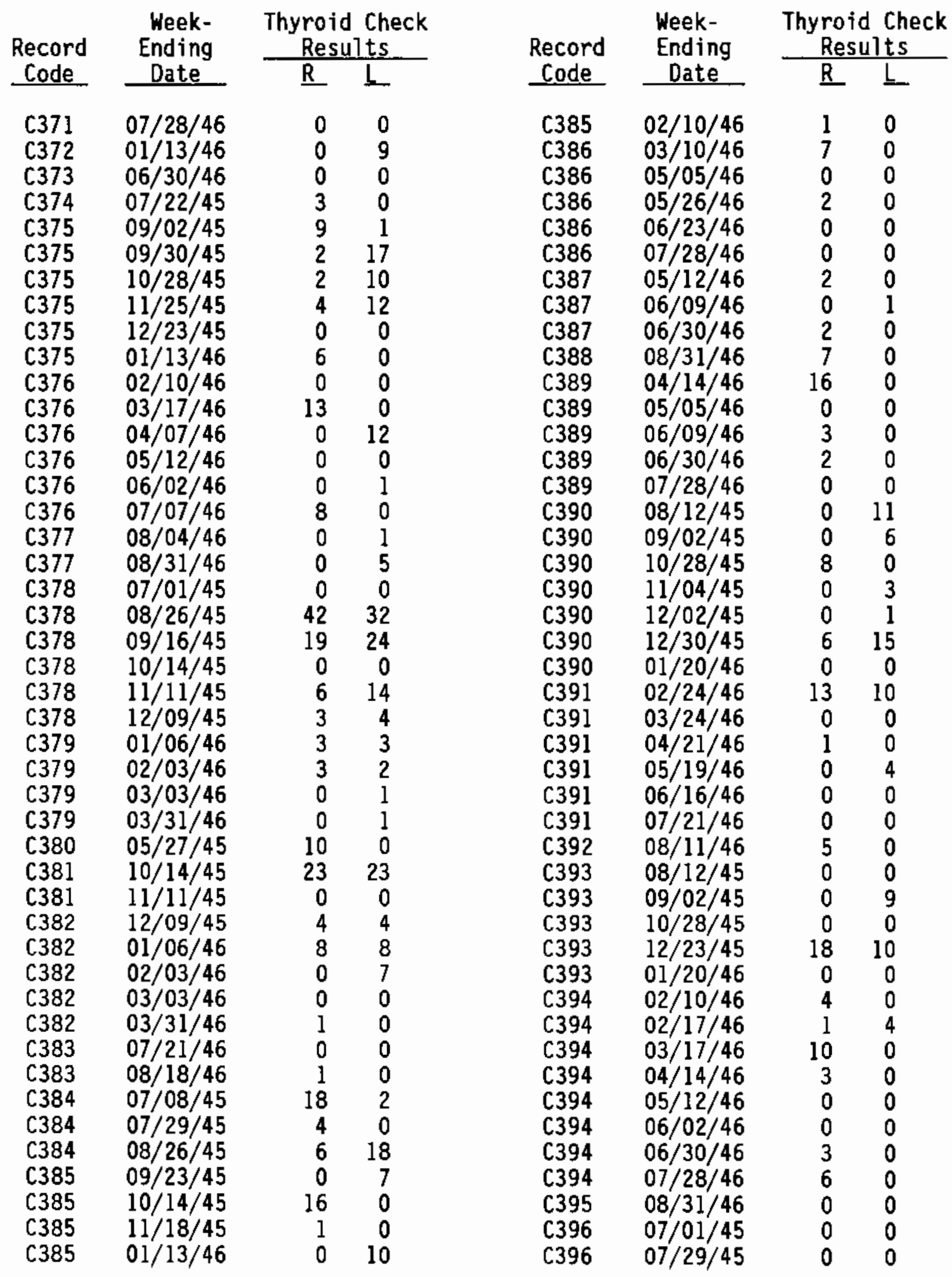


TABLE A.1. (contd)

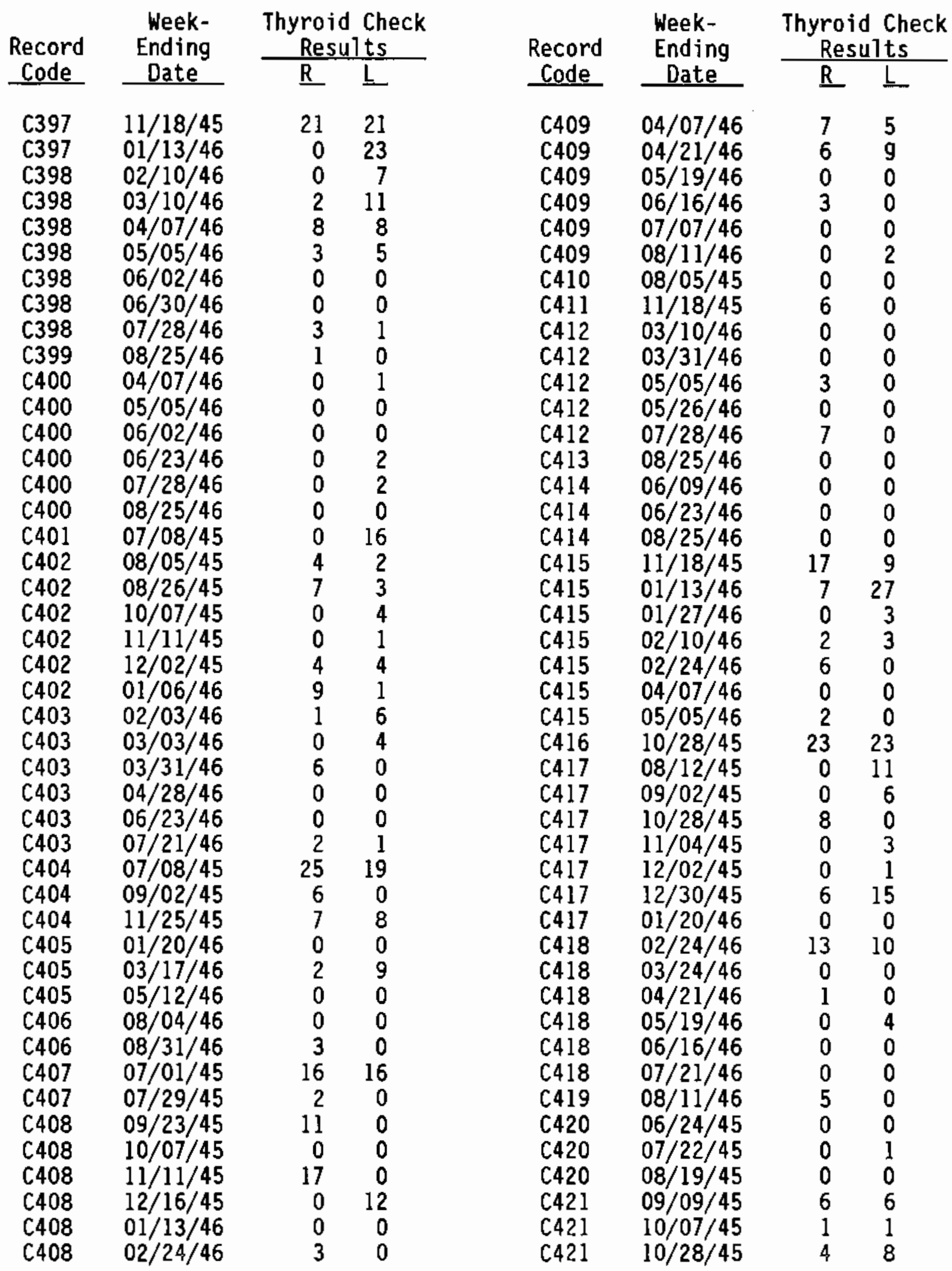


IABLE A.1. (contd)

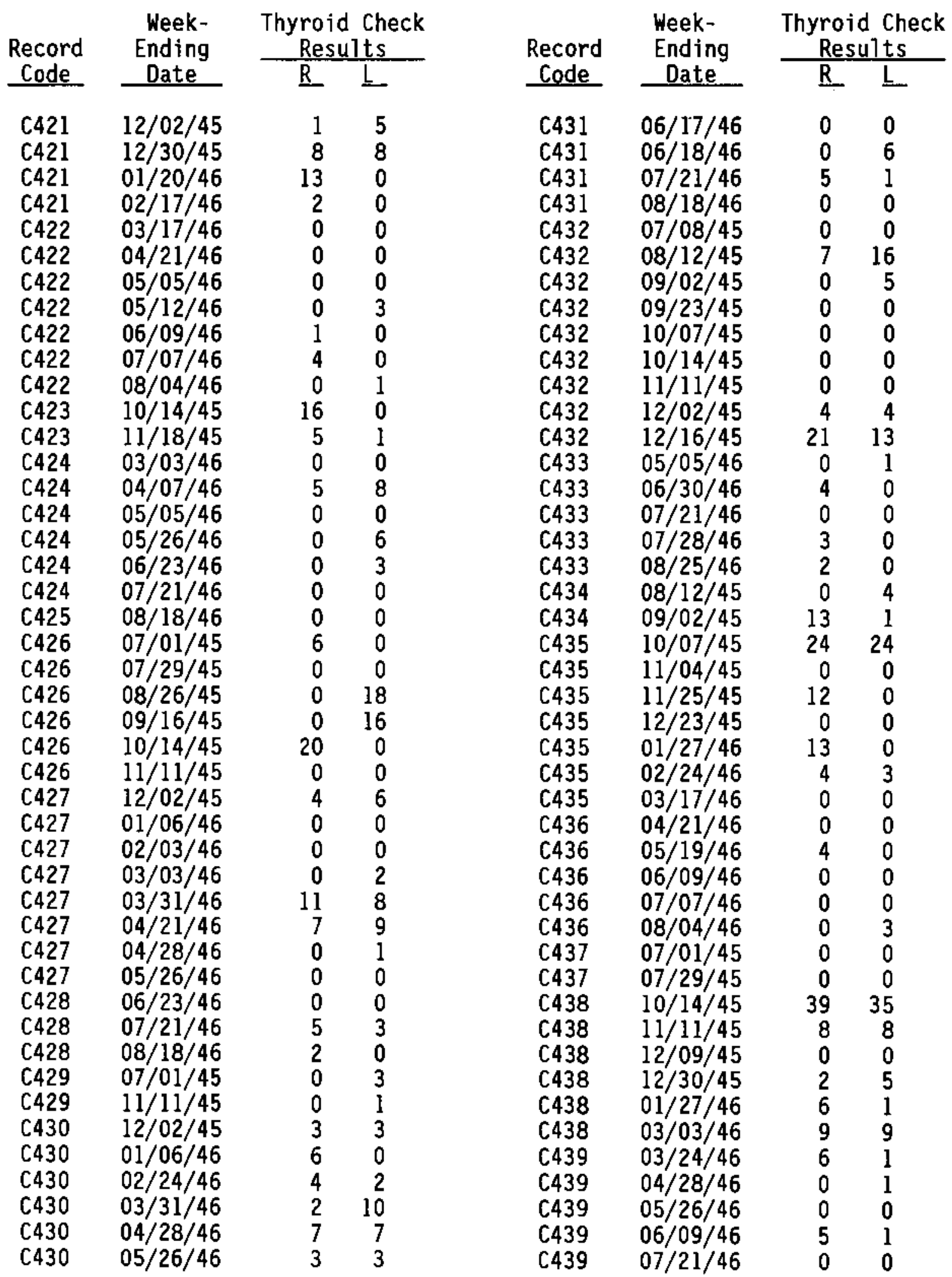


IABLE A.1. (contd)

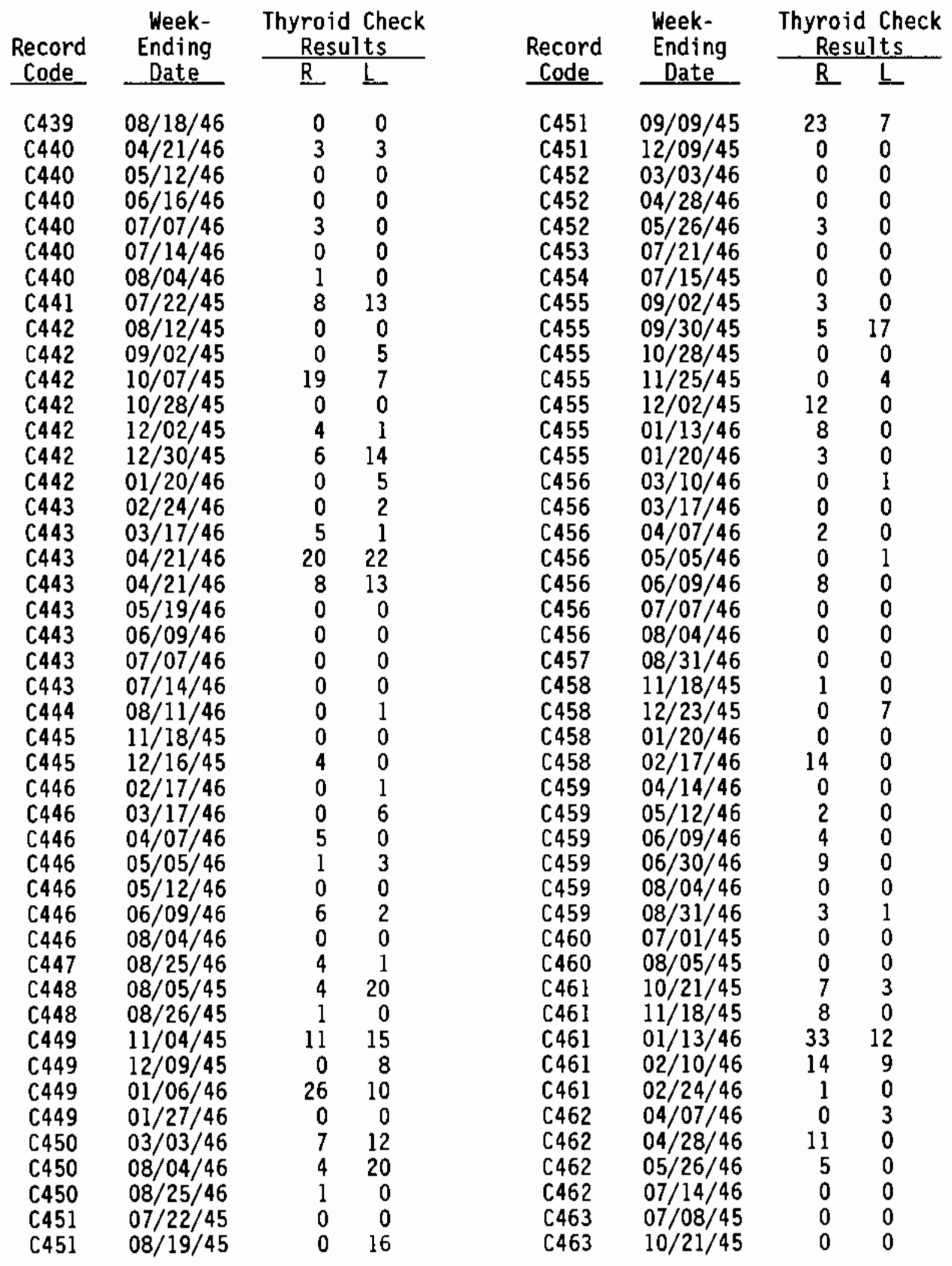


IABLE A.1. (contd)

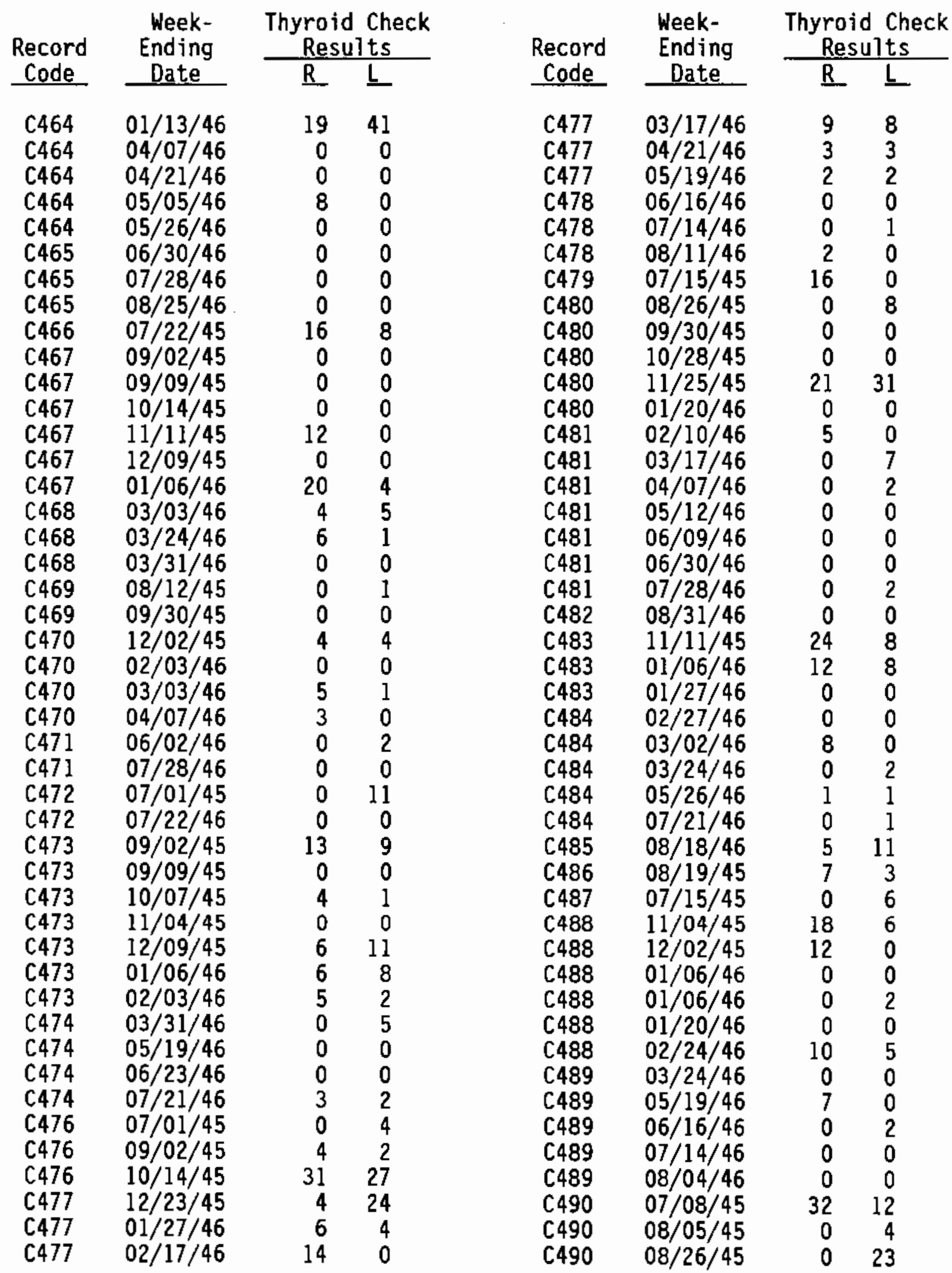


IABLE A.1. (contd)

\begin{tabular}{|c|c|c|c|c|c|c|c|}
\hline \multirow{2}{*}{$\begin{array}{c}\text { Record } \\
\text { Code }\end{array}$} & $\begin{array}{l}\text { Week- } \\
\text { Ending }\end{array}$ & \multicolumn{2}{|c|}{$\begin{array}{l}\text { Thyroid Check } \\
\text { Results }\end{array}$} & \multirow{2}{*}{$\begin{array}{l}\text { Record } \\
\text { Code }\end{array}$} & \multirow{2}{*}{$\begin{array}{l}\text { Week- } \\
\text { Ending } \\
\text { Date }\end{array}$} & \multicolumn{2}{|c|}{$\begin{array}{l}\text { Thyroid Checl } \\
\text { Results } \\
\end{array}$} \\
\hline & & $\underline{\mathrm{R}}$ & $\underline{L}$ & & & $\mathrm{R}$ & $\underline{L}$ \\
\hline C491 & $09 / 23 / 45$ & 0 & 3 & C501 & $07 / 28 / 46$ & 0 & 0 \\
\hline C491 & $10 / 21 / 45$ & 0 & 0 & C501 & $08 / 25 / 46$ & 0 & 0 \\
\hline C491 & $11 / 18 / 45$ & 0 & 0 & C502 & $07 / 22 / 45$ & 1 & 0 \\
\hline C491 & $12 / 16 / 45$ & 0 & 0 & $\mathrm{C} 502$ & $08 / 12 / 45$ & 0 & 0 \\
\hline C491 & $01 / 13 / 46$ & 0 & 0 & C502 & $09 / 02 / 45$ & 0 & 9 \\
\hline C492 & $03 / 03 / 46$ & 0 & 2 & C502 & $09 / 30 / 45$ & 0 & 0 \\
\hline C492 & $04 / 07 / 46$ & 3 & 0 & C502 & $10 / 28 / 45$ & 0 & 0 \\
\hline C492 & $05 / 05 / 46$ & 0 & 0 & C502 & $11 / 25 / 45$ & 5 & 10 \\
\hline C492 & $06 / 02 / 46$ & 0 & 2 & C503 & $12 / 16 / 45$ & $g$ & 15 \\
\hline C492 & $06 / 23 / 46$ & 0 & 3 & C503 & $01 / 20 / 46$ & 0 & 0 \\
\hline C493 & $07 / 08 / 45$ & 0 & 14 & C503 & $02 / 10 / 46$ & 6 & 1 \\
\hline C493 & $07 / 29 / 45$ & 20 & 0 & C503 & $03 / 17 / 46$ & 1 & 1 \\
\hline C494 & $08 / 26 / 45$ & 10 & 2 & C503 & $04 / 14 / 46$ & 5 & 0 \\
\hline C494 & $09 / 23 / 45$ & 3 & 0 & C503 & $05 / 05 / 46$ & 0 & 0 \\
\hline C494 & $10 / 21 / 45$ & 0 & 0 & $\mathrm{C} 503$ & $06 / 02 / 46$ & 2 & 0 \\
\hline C494 & $11 / 18 / 45$ & 0 & 0 & C504 & $06 / 09 / 46$ & 2 & 0 \\
\hline C494 & $12 / 09 / 45$ & 13 & 0 & C504 & $06 / 30 / 46$ & 1 & 0 \\
\hline C494 & $02 / 10 / 46$ & 0 & 0 & C504 & $08 / 04 / 46$ & 0 & 3 \\
\hline C495 & $03 / 10 / 46$ & 1 & 4 & C504 & $08 / 25 / 46$ & 0 & 0 \\
\hline C495 & $04 / 07 / 46$ & 0 & 6 & C505 & $10 / 28 / 45$ & 0 & 0 \\
\hline C496 & $07 / 08 / 45$ & 0 & 0 & C505 & $11 / 04 / 45$ & 15 & 0 \\
\hline C496 & $08 / 05 / 45$ & 27 & 3 & C506 & $12 / 02 / 45$ & 0 & 0 \\
\hline C496 & $08 / 26 / 45$ & 0 & 6 & C506 & $12 / 23 / 45$ & 8 & 0 \\
\hline C496 & $09 / 23 / 45$ & 14 & 6 & C506 & $01 / 27 / 46$ & 0 & 0 \\
\hline C496 & $10 / 21 / 45$ & 0 & 6 & C506 & $02 / 17 / 46$ & 1 & 6 \\
\hline C496 & $11 / 11 / 45$ & 0 & 0 & C507 & $04 / 21 / 46$ & 0 & 1 \\
\hline C496 & $12 / 09 / 45$ & 0 & 1 & C507 & $05 / 19 / 46$ & 0 & 1 \\
\hline C497 & $02 / 03 / 46$ & 5 & 8 & $\mathrm{C} 507$ & $06 / 09 / 46$ & 0 & 4 \\
\hline C497 & $04 / 07 / 46$ & 1 & 0 & C507 & $07 / 07 / 46$ & 0 & 1 \\
\hline C497 & $05 / 05 / 46$ & 0 & 0 & C507 & $08 / 04 / 46$ & 0 & 2 \\
\hline C497 & $06 / 02 / 46$ & 2 & 4 & C507 & $08 / 31 / 46$ & 2 & 0 \\
\hline C497 & $06 / 23 / 46$ & 3 & 0 & C508 & $07 / 01 / 45$ & 0 & 0 \\
\hline C498 & $08 / 25 / 45$ & 1 & 7 & C508 & $10 / 21 / 45$ & 7 & 0 \\
\hline C499 & $10 / 28 / 45$ & 0 & 0 & C508 & $11 / 18 / 45$ & 0 & 14 \\
\hline C499 & $12 / 16 / 45$ & 10 & 0 & C509 & $01 / 13 / 46$ & 12 & 10 \\
\hline C499 & $02 / 17 / 46$ & 0 & 0 & C509 & $04 / 07 / 46$ & 0 & 0 \\
\hline C500 & $03 / 17 / 46$ & 0 & 0 & C509 & $05 / 05 / 46$ & 9 & 5 \\
\hline C500 & $04 / 07 / 46$ & 5 & 4 & C510 & $06 / 02 / 46$ & 0 & 0 \\
\hline C500 & $06 / 09 / 46$ & 0 & 0 & C510 & $06 / 30 / 46$ & 0 & 0 \\
\hline C500 & $07 / 07 / 46$ & 7 & 0 & C510 & $07 / 28 / 46$ & 2 & 0 \\
\hline C500 & $08 / 31 / 46$ & 0 & 0 & C510 & $08 / 25 / 46$ & $\overline{1}$ & 0 \\
\hline C501 & $05 / 05 / 46$ & 0 & 0 & C511 & $07 / 08 / 45$ & 28 & 0 \\
\hline C501 & $06 / 02 / 46$ & 0 & 6 & C511 & $08 / 05 / 45$ & 0 & 0 \\
\hline C501 & $06 / 30 / 46$ & 0 & 0 & C511 & $08 / 26 / 45$ & 11 & 7 \\
\hline C501 & $07 / 21 / 46$ & 0 & 0 & C512 & $10 / 21 / 45$ & 0 & 0 \\
\hline
\end{tabular}


TABLE A.1. (contd)

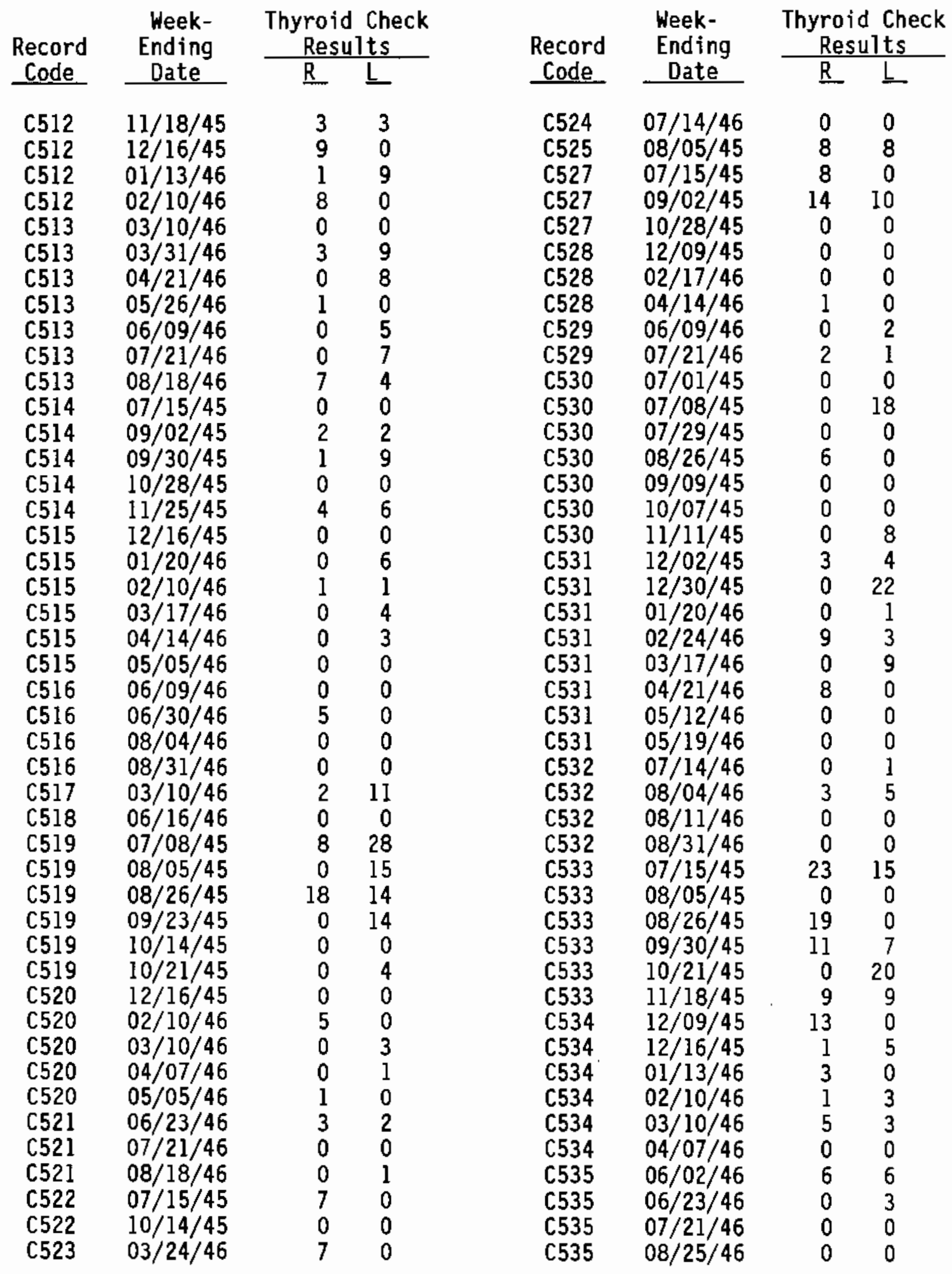


TABLE A.1. (contd)

\begin{tabular}{|c|c|c|c|c|c|c|c|}
\hline \multirow{2}{*}{$\begin{array}{l}\text { Record } \\
\text { Code } \\
\end{array}$} & \multirow{2}{*}{$\begin{array}{c}\text { Week- } \\
\text { Ending } \\
\text { Date } \\
\end{array}$} & \multicolumn{2}{|c|}{$\begin{array}{l}\text { Thyroid Check } \\
\text { Results }\end{array}$} & \multirow{2}{*}{$\begin{array}{l}\text { Record } \\
\text { Code }\end{array}$} & \multirow{2}{*}{$\begin{array}{l}\text { Week- } \\
\text { Ending } \\
\text { Date }\end{array}$} & \multicolumn{2}{|c|}{$\begin{array}{l}\text { Thyroid Che } \\
\text { Results } \\
\end{array}$} \\
\hline & & R & $\underline{\mathrm{L}}$ & & & R & $\underline{\mathrm{L}}$ \\
\hline C536 & $04 / 28 / 46$ & 0 & 0 & C547 & $01 / 06 / 46$ & 16 & 0 \\
\hline C536 & $05 / 26 / 46$ & 0 & 0 & C547 & $02 / 03 / 46$ & 7 & 1 \\
\hline C536 & $06 / 23 / 46$ & 7 & 9 & C547 & $03 / 03 / 46$ & 0 & 0 \\
\hline C536 & $07 / 21 / 46$ & 5 & 0 & C547 & $03 / 31 / 46$ & 3 & 5 \\
\hline C536 & $08 / 18 / 46$ & 0 & 0 & C547 & $04 / 21 / 46$ & 0 & 0 \\
\hline C537 & $04 / 21 / 46$ & 1 & 1 & C547 & $04 / 28 / 46$ & 0 & 0 \\
\hline C537 & $05 / 12 / 46$ & 2 & 0 & C547 & $05 / 19 / 46$ & 0 & 0 \\
\hline C537 & $06 / 09 / 46$ & 0 & 0 & C548 & $07 / 21 / 46$ & 0 & 2 \\
\hline C537 & $07 / 07 / 46$ & 0 & 0 & C549 & $07 / 01 / 45$ & 0 & 15 \\
\hline C537 & $08 / 04 / 46$ & 0 & 0 & C549 & $07 / 22 / 45$ & 0 & 5 \\
\hline C537 & $08 / 31 / 46$ & 0 & 0 & C549 & $08 / 19 / 45$ & 14 & 6 \\
\hline C538 & $06 / 17 / 45$ & 0 & 5 & C549 & $09 / 09 / 45$ & 1 & 0 \\
\hline C539 & $01 / 27 / 45$ & 6 & 3 & C549 & $10 / 07 / 45$ & 0 & 12 \\
\hline C539 & $07 / 29 / 45$ & 2 & 14 & C549 & $11 / 11 / 45$ & 1 & 1 \\
\hline C540 & $08 / 26 / 45$ & 0 & 18 & C550 & $12 / 09 / 45$ & 5 & 1 \\
\hline C540 & $09 / 02 / 45$ & 0 & 0 & C550 & $01 / 06 / 46$ & 0 & 0 \\
\hline C540 & $09 / 16 / 45$ & 5 & 7 & C550 & $02 / 03 / 46$ & 0 & 3 \\
\hline C540 & $10 / 07 / 45$ & 4 & 0 & C550 & $03 / 03 / 46$ & 0 & 2 \\
\hline C540 & $11 / 11 / 45$ & 9 & 31 & C550 & $03 / 31 / 46$ & 0 & 12 \\
\hline C540 & $11 / 18 / 45$ & 0 & 4 & C550 & $04 / 28 / 46$ & 0 & 0 \\
\hline C540 & $12 / 02 / 45$ & 8 & 3 & C550 & $05 / 26 / 46$ & 1 & 4 \\
\hline C540 & $02 / 03 / 46$ & 0 & 0 & C551 & $06 / 23 / 46$ & 0 & 0 \\
\hline C541 & $02 / 24 / 46$ & 0 & 0 & C551 & $07 / 14 / 46$ & 5 & 0 \\
\hline C541 & $03 / 31 / 46$ & 6 & 3 & C551 & $08 / 18 / 46$ & 0 & 0 \\
\hline C541 & $04 / 28 / 46$ & 0 & 0 & C552 & $07 / 15 / 45$ & 8 & 0 \\
\hline C541 & $05 / 26 / 46$ & 0 & 0 & C553 & $10 / 21 / 45$ & 14 & 6 \\
\hline C541 & $06 / 16 / 46$ & 0 & 0 & C553 & $12 / 23 / 45$ & 0 & 0 \\
\hline C542 & $08 / 18 / 46$ & 6 & 0 & C553 & $01 / 20 / 46$ & 3 & 0 \\
\hline C543 & $07 / 01 / 45$ & 0 & 0 & C553 & $02 / 17 / 46$ & 5 & 0 \\
\hline C543 & $07 / 29 / 45$ & 7 & 3 & C554 & $03 / 17 / 46$ & 3 & 2 \\
\hline C543 & $08 / 26 / 45$ & 0 & 20 & C554 & $04 / 14 / 46$ & 4 & 0 \\
\hline C543 & $10 / 07 / 45$ & 5 & 5 & C554 & $05 / 12 / 46$ & 0 & 0 \\
\hline C544 & $12 / 09 / 45$ & 4 & 3 & C554 & $06 / 02 / 46$ & 1 & 0 \\
\hline C544 & $03 / 17 / 46$ & 0 & 13 & C554 & $07 / 07 / 46$ & 0 & 6 \\
\hline C544 & $04 / 07 / 46$ & 0 & 11 & C554 & $07 / 28 / 46$ & 1 & 3 \\
\hline C544 & $05 / 05 / 46$ & 0 & 0 & C554 & $08 / 31 / 46$ & 2 & 3 \\
\hline C544 & $05 / 26 / 46$ & 0 & 0 & C555 & $07 / 01 / 45$ & 7 & 11 \\
\hline C545 & $07 / 07 / 46$ & 5 & 0 & C555 & $07 / 22 / 45$ & 0 & 0 \\
\hline C545 & $07 / 28 / 46$ & 0 & 0 & C555 & $08 / 12 / 45$ & 1 & 13 \\
\hline C545 & $08 / 31 / 46$ & 2 & 0 & C555 & $09 / 02 / 45$ & 0 & 12 \\
\hline C546 & $07 / 15 / 45$ & 23 & 0 & C555 & $10 / 28 / 45$ & 2 & 0 \\
\hline C546 & $08 / 26 / 45$ & 13 & 17 & C556 & $12 / 02 / 45$ & 0 & 0 \\
\hline C546 & $0 \mathrm{~g} / 23 / 45$ & 7 & 0 & C556 & $01 / 13 / 46$ & 3 & 5 \\
\hline C546 & $11 / 11 / 45$ & 0 & 0 & C556 & $02 / 17 / 46$ & 0 & 0 \\
\hline C547 & $12 / 09 / 45$ & 5 & 7 & C556 & $03 / 17 / 46$ & 0 & 0 \\
\hline
\end{tabular}


IABLE A.1. (contd)

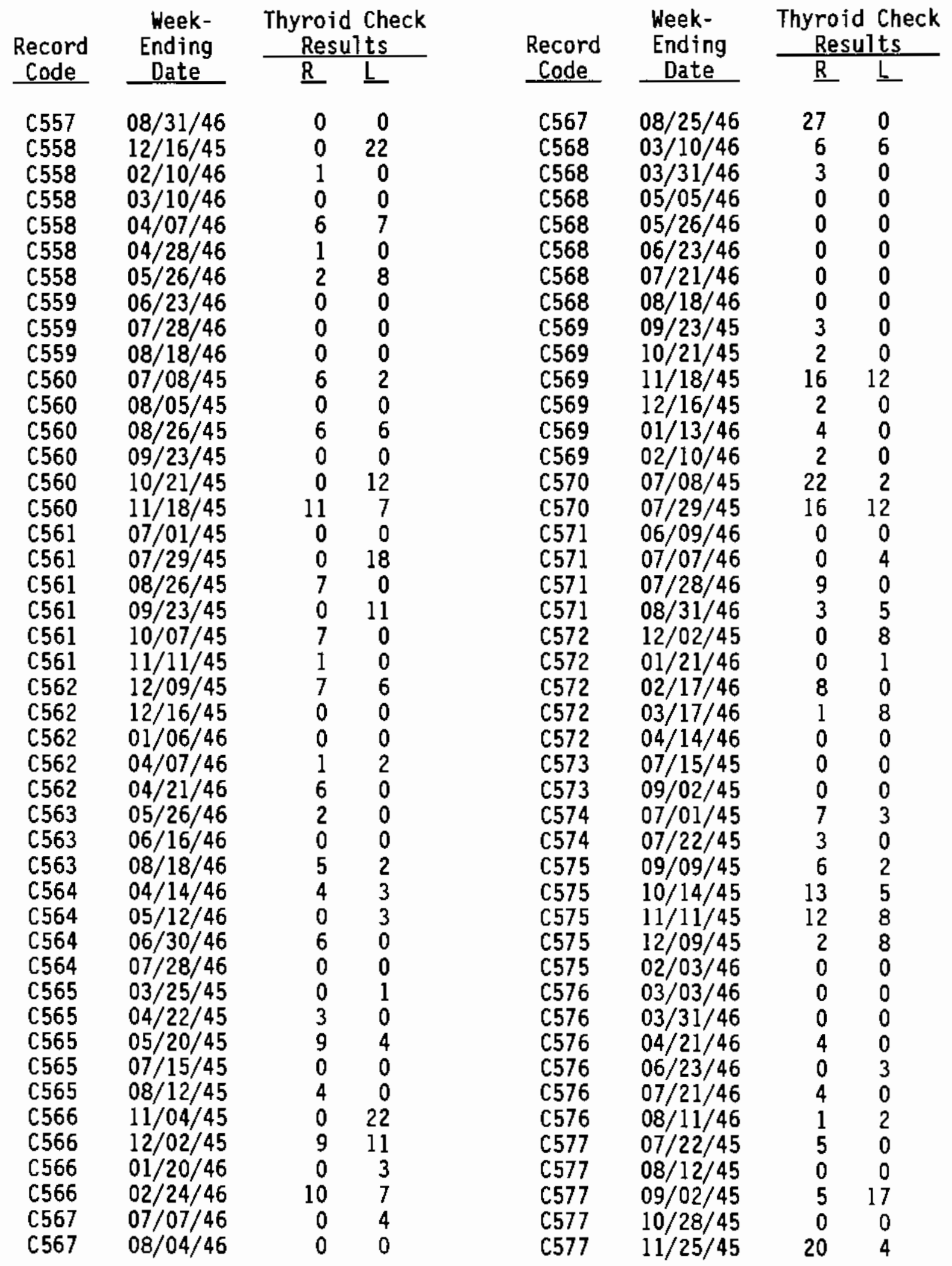


IABLE A.1. (contd)

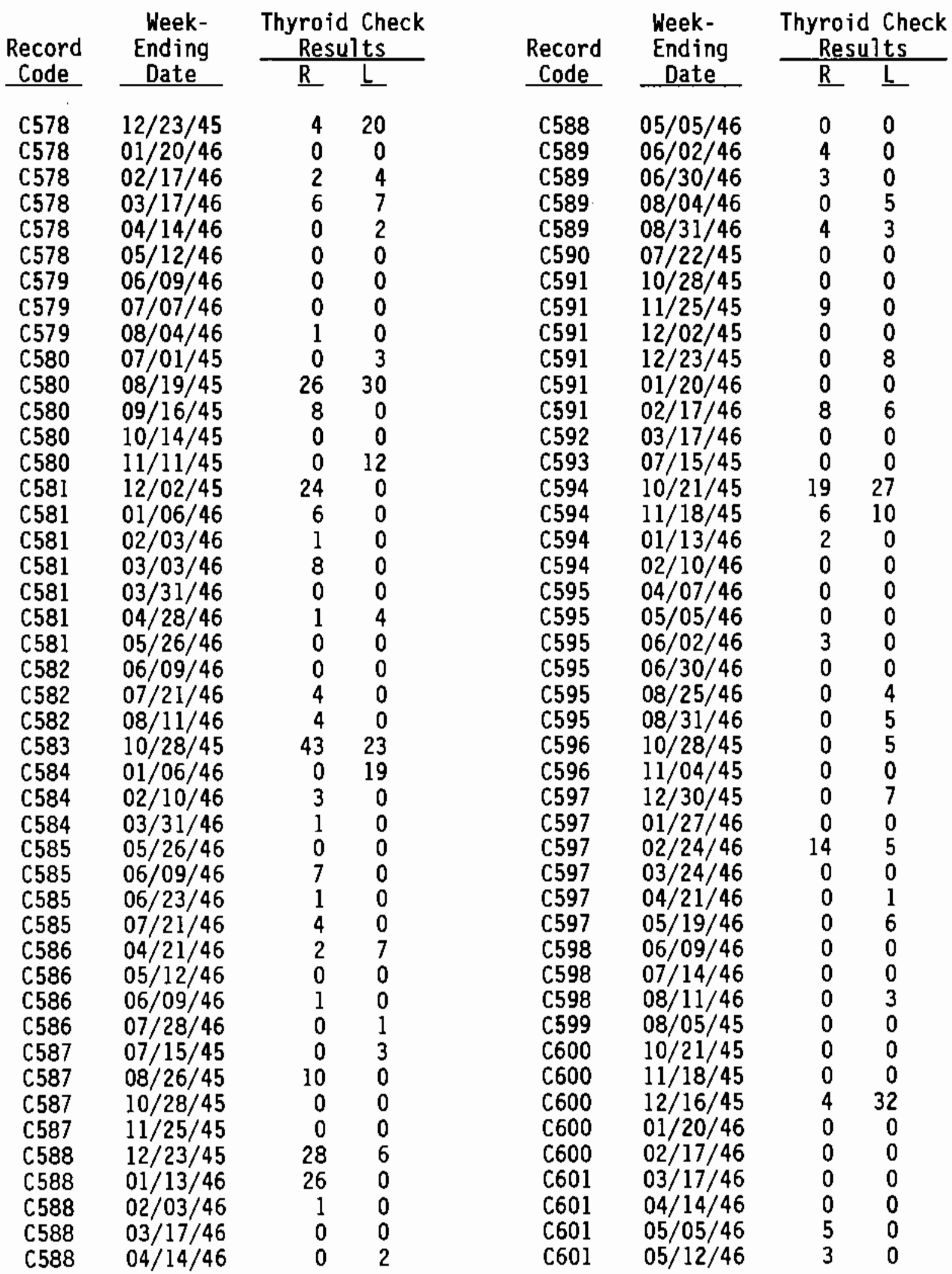


IABLE A.1. (contd)

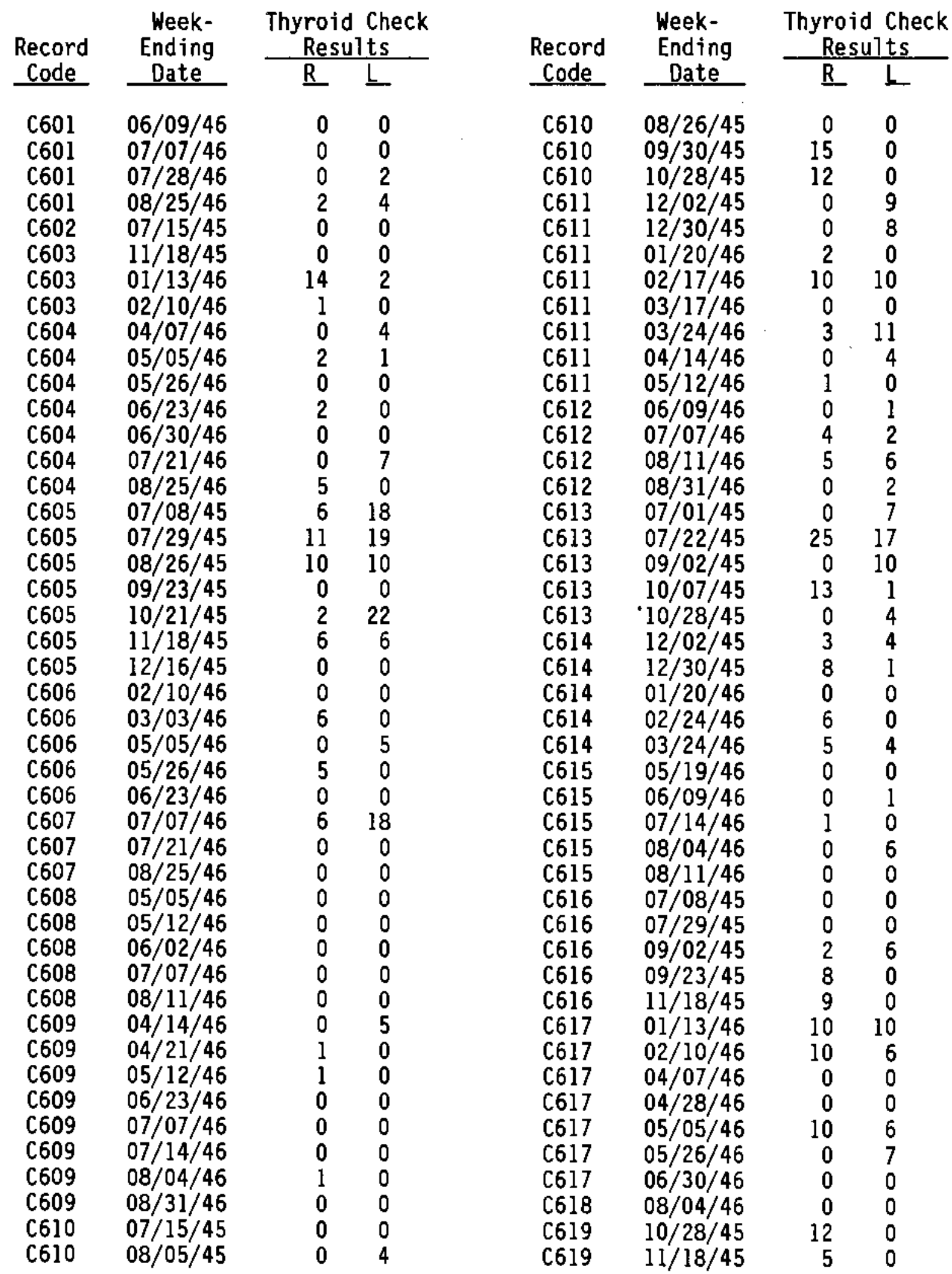


IABLE A.1. (contd)

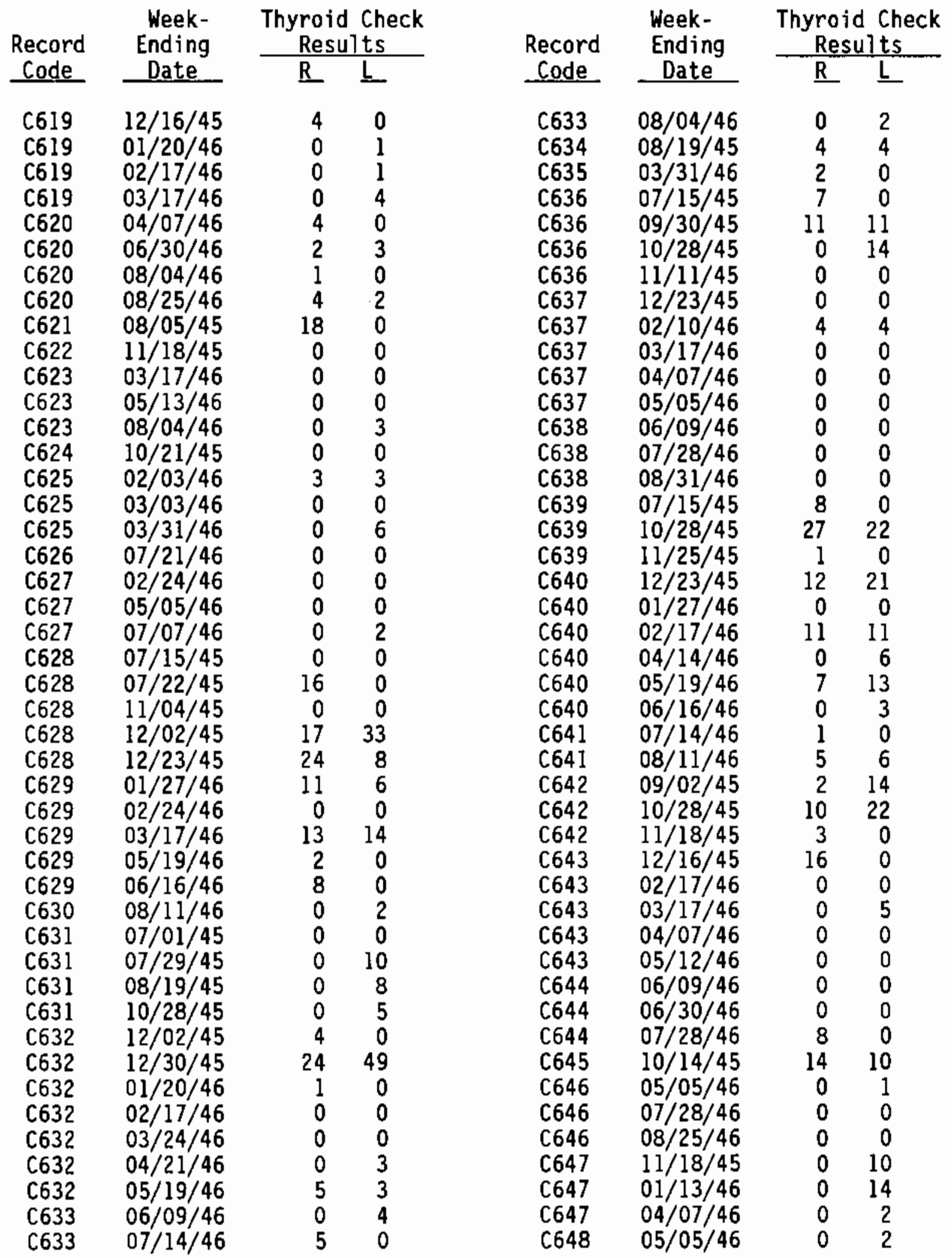


IABLE A.1. (contd)

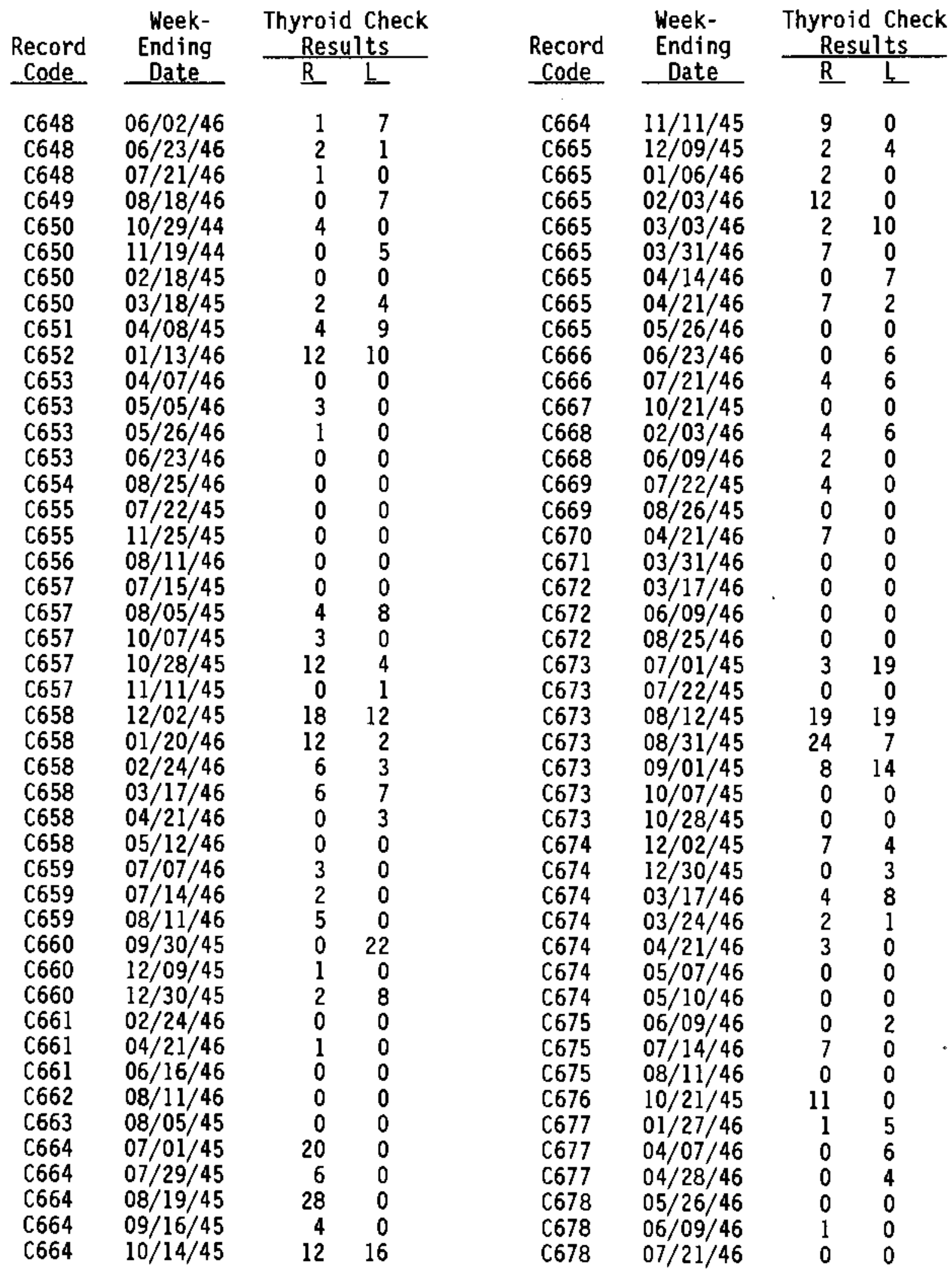


TABLE A.1. (contd)

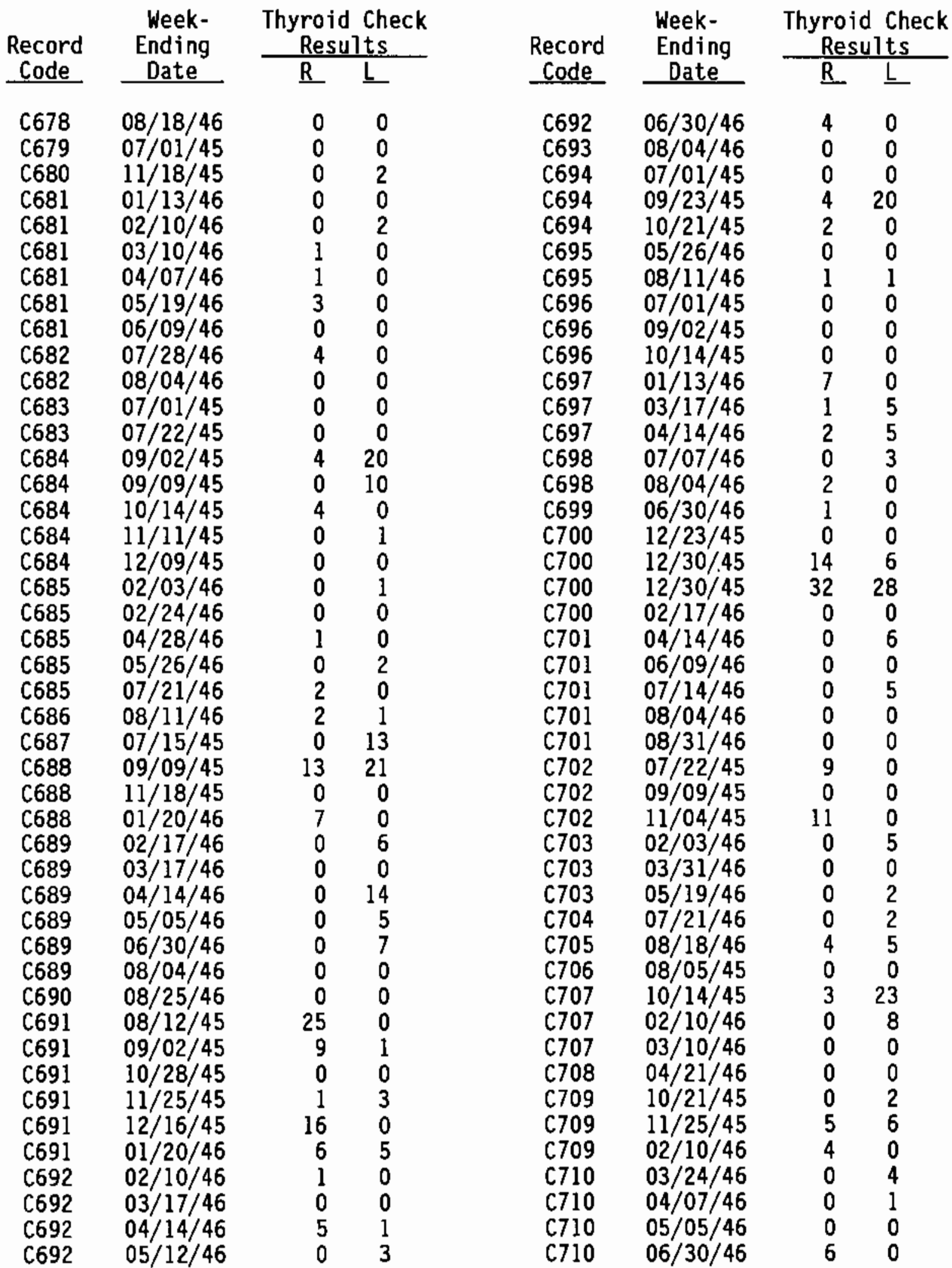


TABLE A.1. (contd)

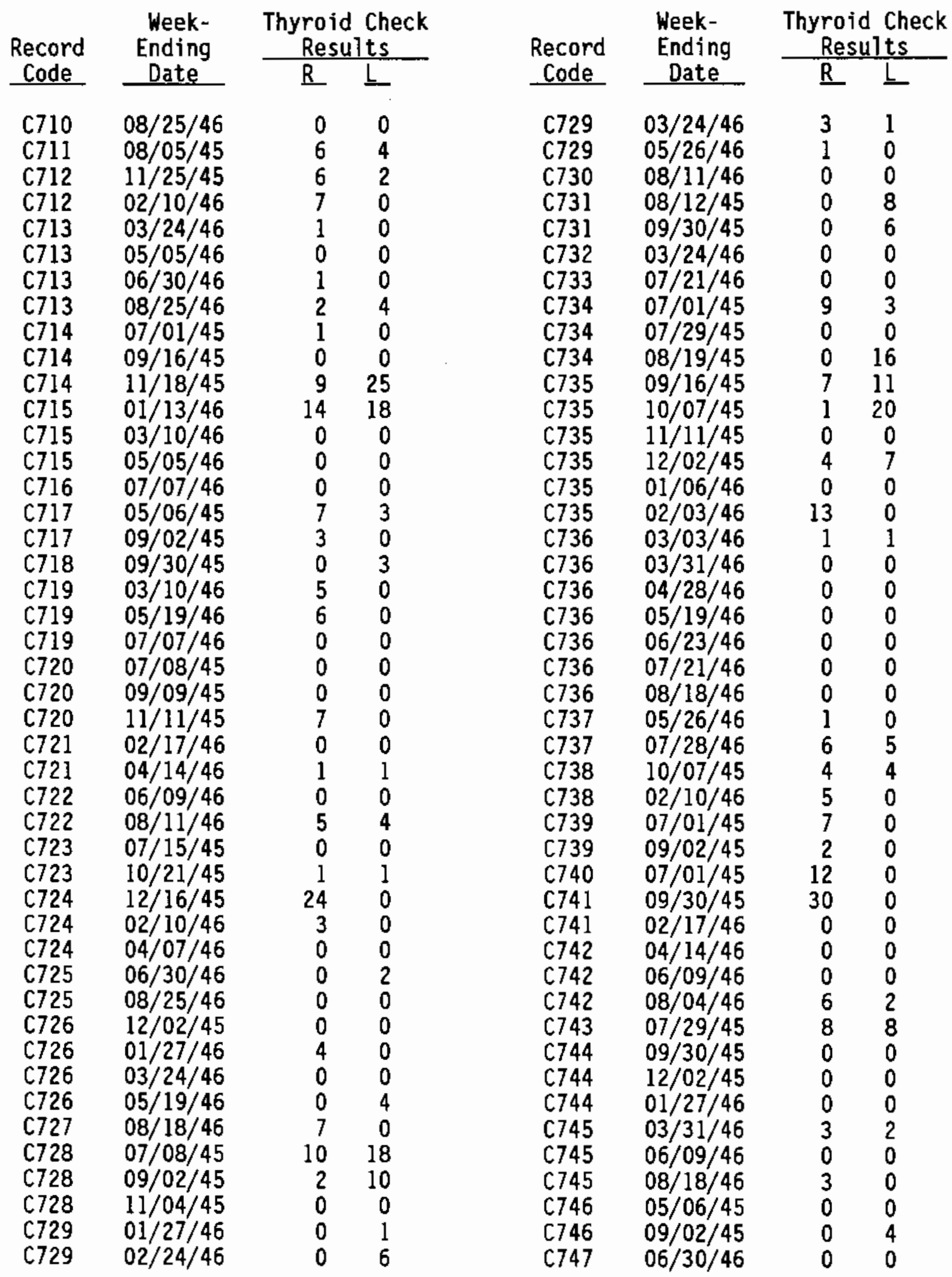


IABLE A.1. (contd)

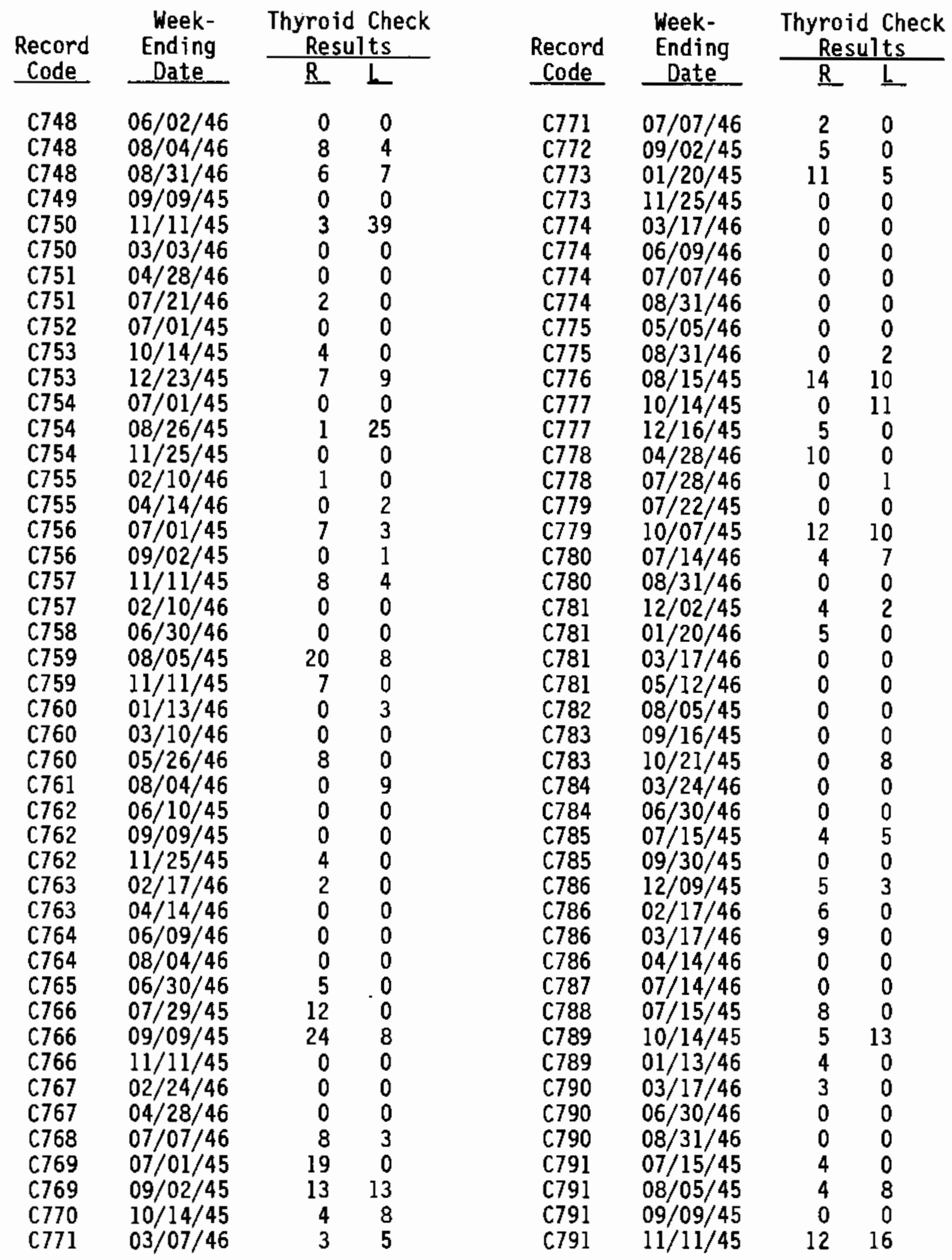


IABLE A.1. (contd)

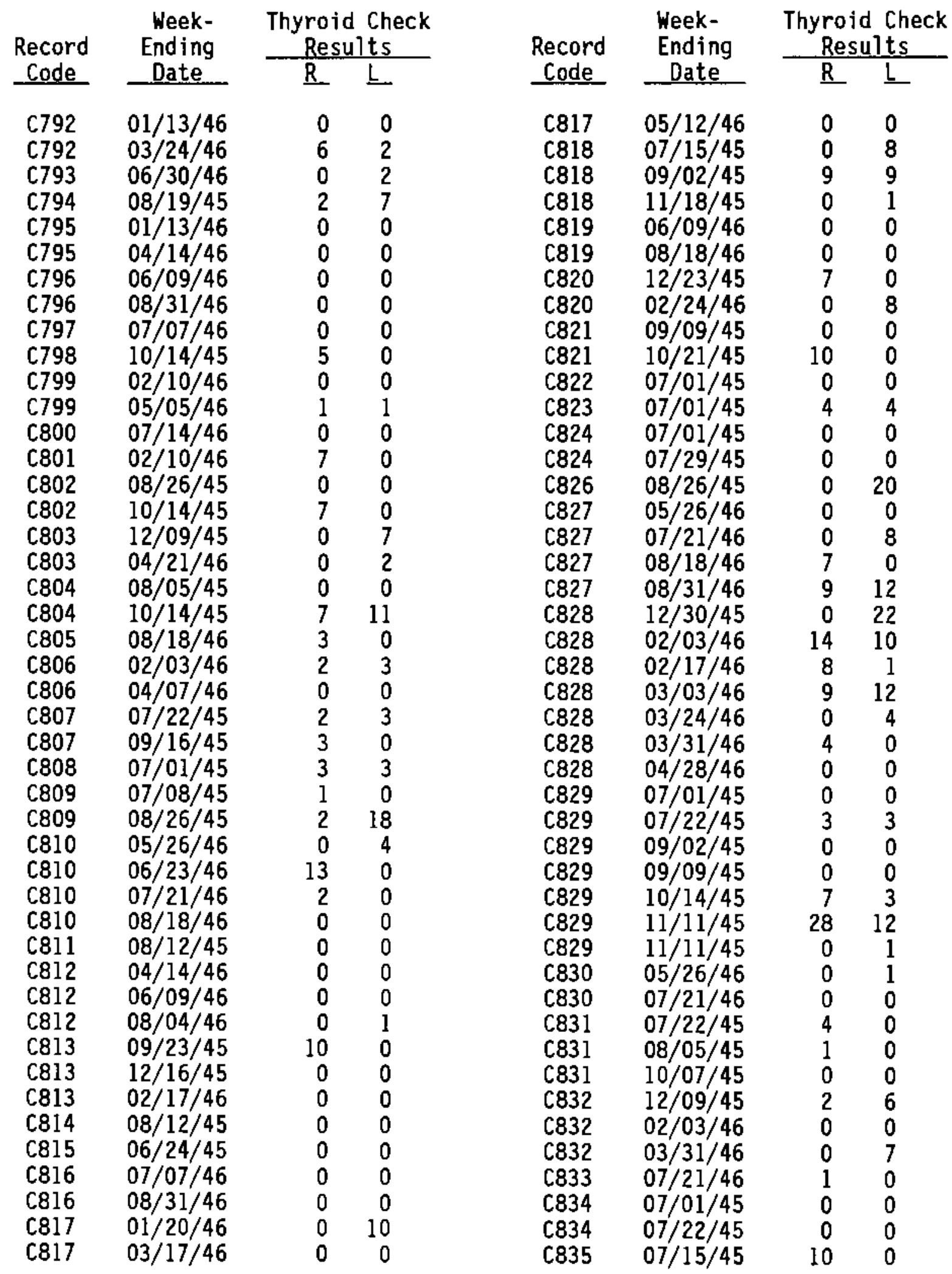


TABLE A.1. (contd)

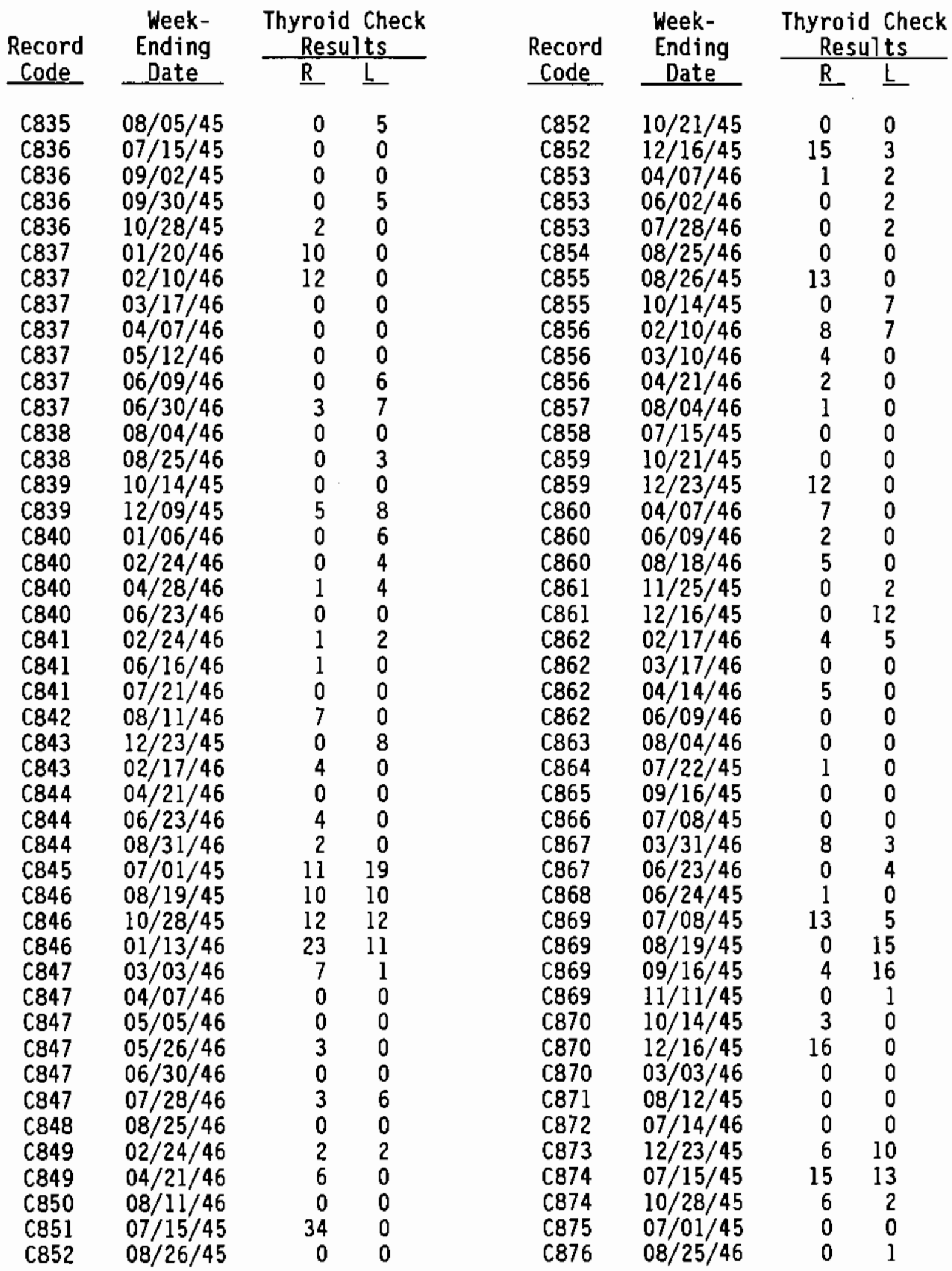


IABLE A.1. (contd)

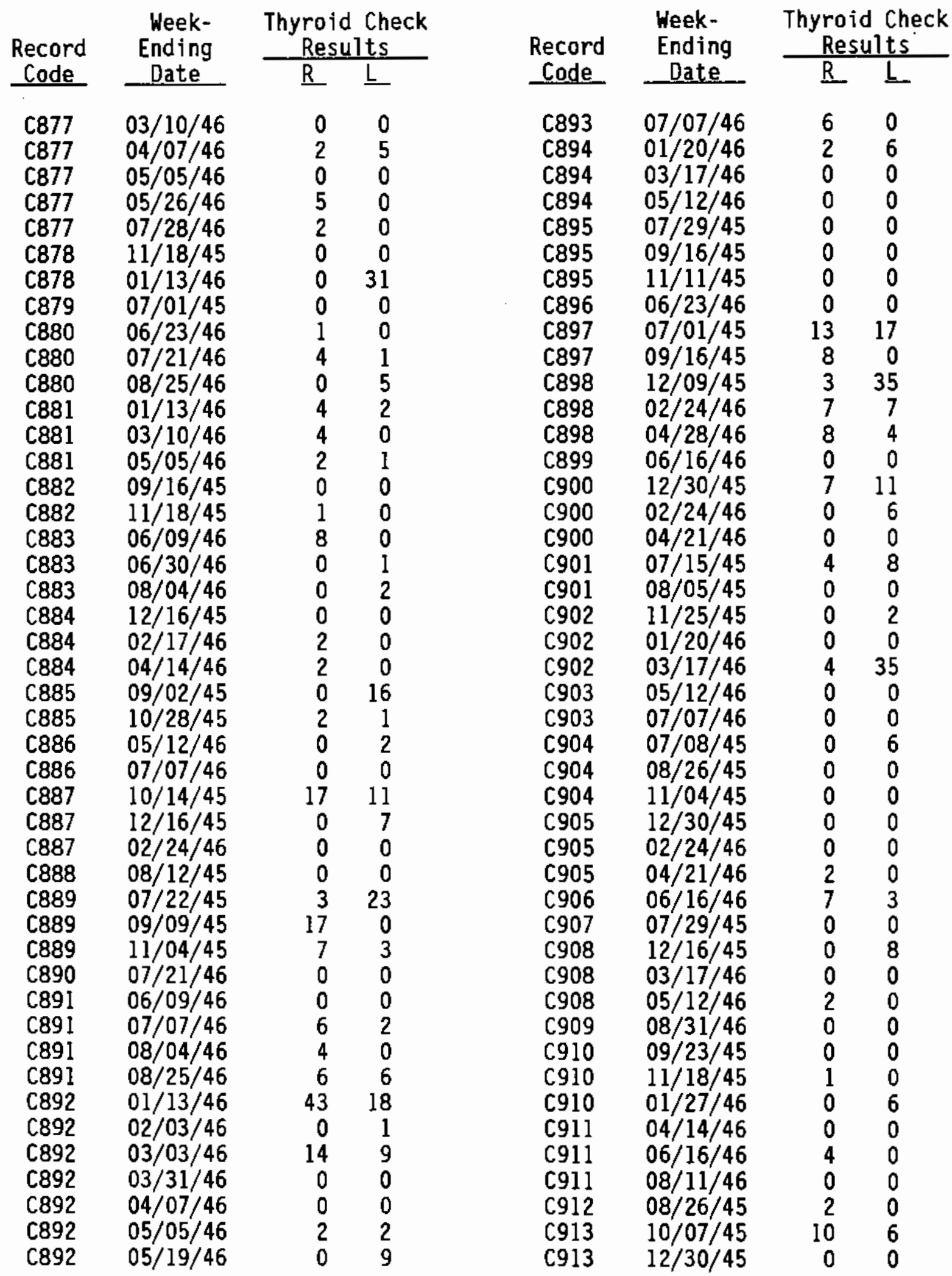


TABLE A.1. (contd)

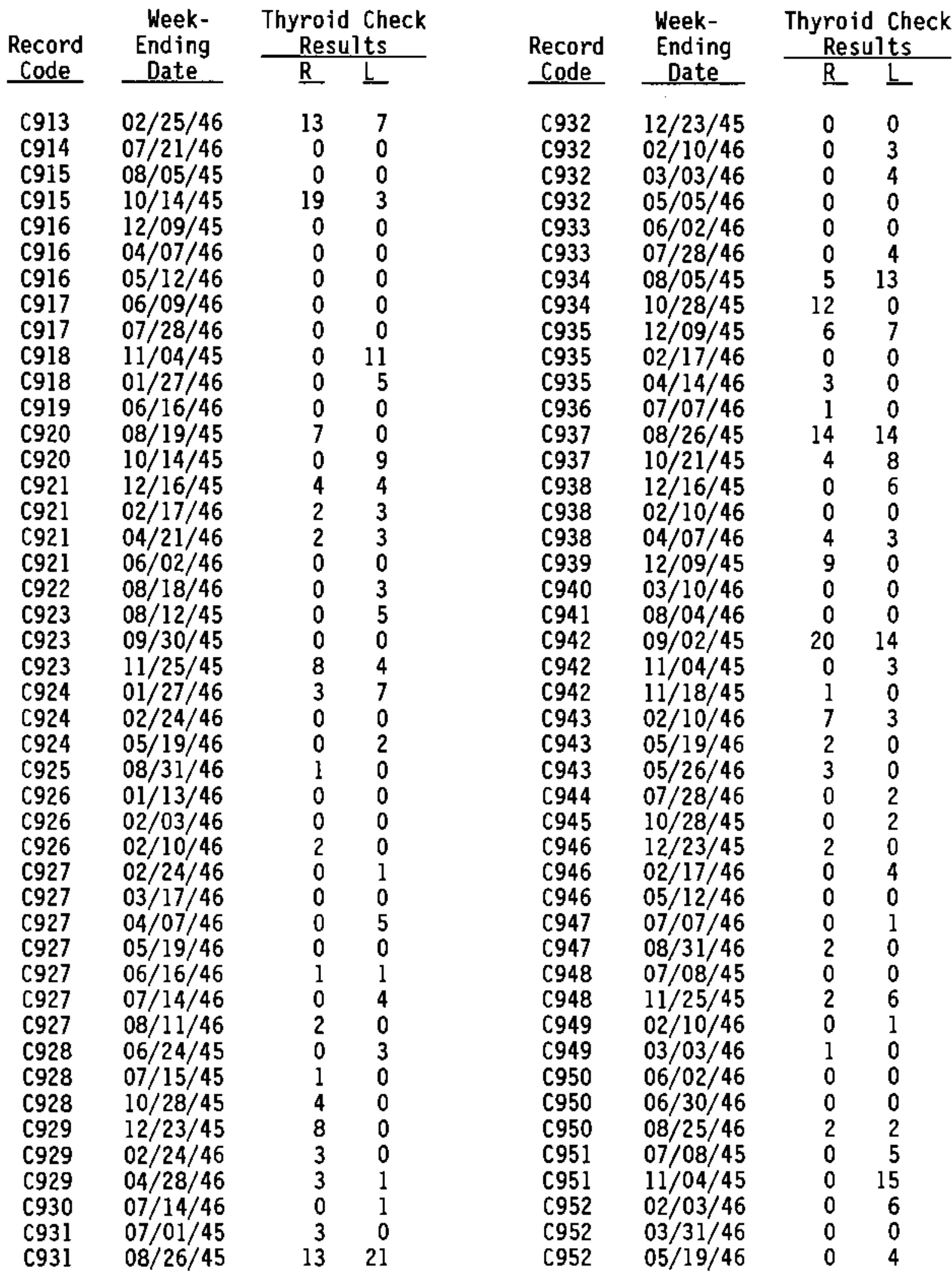


TABLE A.1. (contd)

\begin{tabular}{|c|c|c|c|c|c|c|c|}
\hline \multirow{2}{*}{$\begin{array}{l}\text { Record } \\
\text { Code }\end{array}$} & \multirow{2}{*}{$\begin{array}{c}\text { Week- } \\
\text { Ending } \\
\text { Date } \\
\end{array}$} & \multicolumn{2}{|c|}{$\begin{array}{l}\text { Thyroid Check } \\
\text { Results }\end{array}$} & \multirow{2}{*}{$\begin{array}{l}\text { Record } \\
\text { Code }\end{array}$} & \multirow{2}{*}{$\begin{array}{l}\text { Week- } \\
\text { Ending } \\
\text { Date }\end{array}$} & \multicolumn{2}{|c|}{$\begin{array}{l}\text { Thyroid Check } \\
\text { Results }\end{array}$} \\
\hline & & $\underline{R}$ & $\underline{L}$ & & & $\underline{R}$ & $\underline{L}$ \\
\hline C953 & $07 / 21 / 46$ & 0 & 3 & C964 & $12 / 09 / 45$ & 3 & 0 \\
\hline C954 & $07 / 07 / 46$ & 0 & 0 & C964 & $01 / 06 / 46$ & 2 & 4 \\
\hline C954 & $08 / 04 / 46$ & 0 & 0 & C964 & $02 / 03 / 46$ & 3 & 9 \\
\hline C954 & $08 / 31 / 46$ & 0 & 0 & C964 & $03 / 03 / 46$ & 11 & 10 \\
\hline C955 & $11 / 25 / 45$ & 0 & 5 & C965 & $07 / 15 / 45$ & 8 & 0 \\
\hline C955 & $01 / 20 / 46$ & 9 & 8 & C965 & $08 / 12 / 45$ & 0 & 12 \\
\hline C955 & $02 / 17 / 46$ & 0 & 0 & C965 & $10 / 07 / 45$ & 0 & 16 \\
\hline C955 & $03 / 03 / 46$ & 0 & 0 & C966 & $12 / 16 / 45$ & 9 & 0 \\
\hline C955 & $03 / 10 / 46$ & 0 & 0 & C966 & $02 / 10 / 46$ & 0 & 0 \\
\hline C955 & $04 / 14 / 46$ & 0 & 0 & C966 & $04 / 07 / 46$ & 0 & 2 \\
\hline C955 & $05 / 19 / 46$ & 6 & 0 & C967 & $06 / 16 / 46$ & 0 & 0 \\
\hline C956 & $06 / 10 / 45$ & 16 & 0 & C967 & $08 / 11 / 46$ & 0 & 2 \\
\hline C956 & $08 / 26 / 45$ & 5 & 7 & C968 & $07 / 15 / 45$ & 0 & 0 \\
\hline C956 & $10 / 28 / 45$ & 15 & 29 & C968 & $10 / 21 / 45$ & 10 & 6 \\
\hline C957 & $01 / 06 / 46$ & 24 & 6 & C968 & $11 / 18 / 45$ & 15 & 9 \\
\hline C957 & $02 / 03 / 46$ & 9 & 4 & C968 & $12 / 16 / 45$ & 0 & 0 \\
\hline C957 & $03 / 31 / 46$ & 0 & 0 & C969 & $01 / 20 / 46$ & 1 & 0 \\
\hline C957 & $04 / 28 / 46$ & 0 & 0 & C969 & $02 / 17 / 46$ & 0 & 0 \\
\hline C958 & $05 / 27 / 45$ & 0 & 0 & C969 & $04 / 07 / 46$ & 0 & 0 \\
\hline C958 & $06 / 24 / 45$ & 0 & 0 & C969 & $05 / 12 / 46$ & 4 & 0 \\
\hline C958 & $07 / 15 / 45$ & 1 & 7 & C969 & $06 / 09 / 46$ & i & 0 \\
\hline C958 & $08 / 19 / 45$ & 0 & 0 & C970 & $06 / 30 / 46$ & 3 & 0 \\
\hline C958 & $08 / 26 / 45$ & 4 & 0 & C970 & $07 / 28 / 46$ & 6 & 4 \\
\hline C958 & $10 / 14 / 45$ & 32 & 40 & C970 & $08 / 31 / 46$ & 4 & 0 \\
\hline C958 & $11 / 11 / 45$ & 0 & 0 & C971 & $07 / 22 / 45$ & 0 & 0 \\
\hline C959 & $03 / 11 / 45$ & 2 & 0 & C971 & $09 / 09 / 45$ & 0 & 0 \\
\hline C959 & $04 / 08 / 45$ & 0 & 1 & C971 & $11 / 04 / 45$ & 0 & 0 \\
\hline C959 & $04 / 15 / 45$ & 4 & 2 & C972 & $08 / 05 / 45$ & 0 & 0 \\
\hline C959 & $05 / 06 / 45$ & 0 & 0 & C972 & $11 / 18 / 45$ & 5 & 21 \\
\hline C959 & $05 / 27 / 45$ & 5 & 0 & C972 & $01 / 27 / 46$ & 0 & 4 \\
\hline C959 & $07 / 01 / 45$ & 0 & 0 & C973 & $03 / 31 / 46$ & 0 & 0 \\
\hline C959 & $07 / 29 / 45$ & 4 & 0 & C974 & $08 / 12 / 45$ & 6 & 0 \\
\hline C959 & $08 / 26 / 45$ & 4 & 2 & C974 & $10 / 28 / 45$ & 0 & 0 \\
\hline C959 & $09 / 02 / 45$ & 0 & 9 & C974 & $01 / 20 / 46$ & 2 & 0 \\
\hline C960 & $11 / 18 / 45$ & 0 & 0 & C975 & $03 / 24 / 46$ & 2 & 1 \\
\hline C960 & $12 / 16 / 45$ & 36 & 8 & C976 & $02 / 25 / 45$ & 0 & 2 \\
\hline C960 & $12 / 30 / 45$ & 19 & 0 & C976 & $03 / 25 / 45$ & 0 & 4 \\
\hline$C 960$ & $01 / 20 / 46$ & 0 & 0 & C977 & $07 / 22 / 45$ & 0 & 0 \\
\hline C960 & $02 / 03 / 46$ & 3 & 0 & C977 & $09 / 16 / 45$ & 0 & 0 \\
\hline C961 & $01 / 27 / 46$ & 4 & 0 & C977 & $11 / 11 / 45$ & 0 & 8 \\
\hline C961 & $03 / 24 / 46$ & 4 & 8 & C977 & $12 / 30 / 45$ & 0 & 0 \\
\hline C961 & $05 / 19 / 46$ & 0 & 0 & C978 & $07 / 15 / 45$ & 0 & 12 \\
\hline & $07 / 21 / 46$ & 0 & 0 & C979 & $07 / 22 / 45$ & 0 & 12 \\
\hline $\mathrm{C} 963$ & $07 / 22 / 45$ & 0 & 1 & C980 & $09 / 16 / 45$ & 8 & 0 \\
\hline C96 & $10 / 14 / 45$ & 15 & 19 & C981 & $08 / 19 / 45$ & 0 & 4 \\
\hline
\end{tabular}


TABLE A.1. (contd)

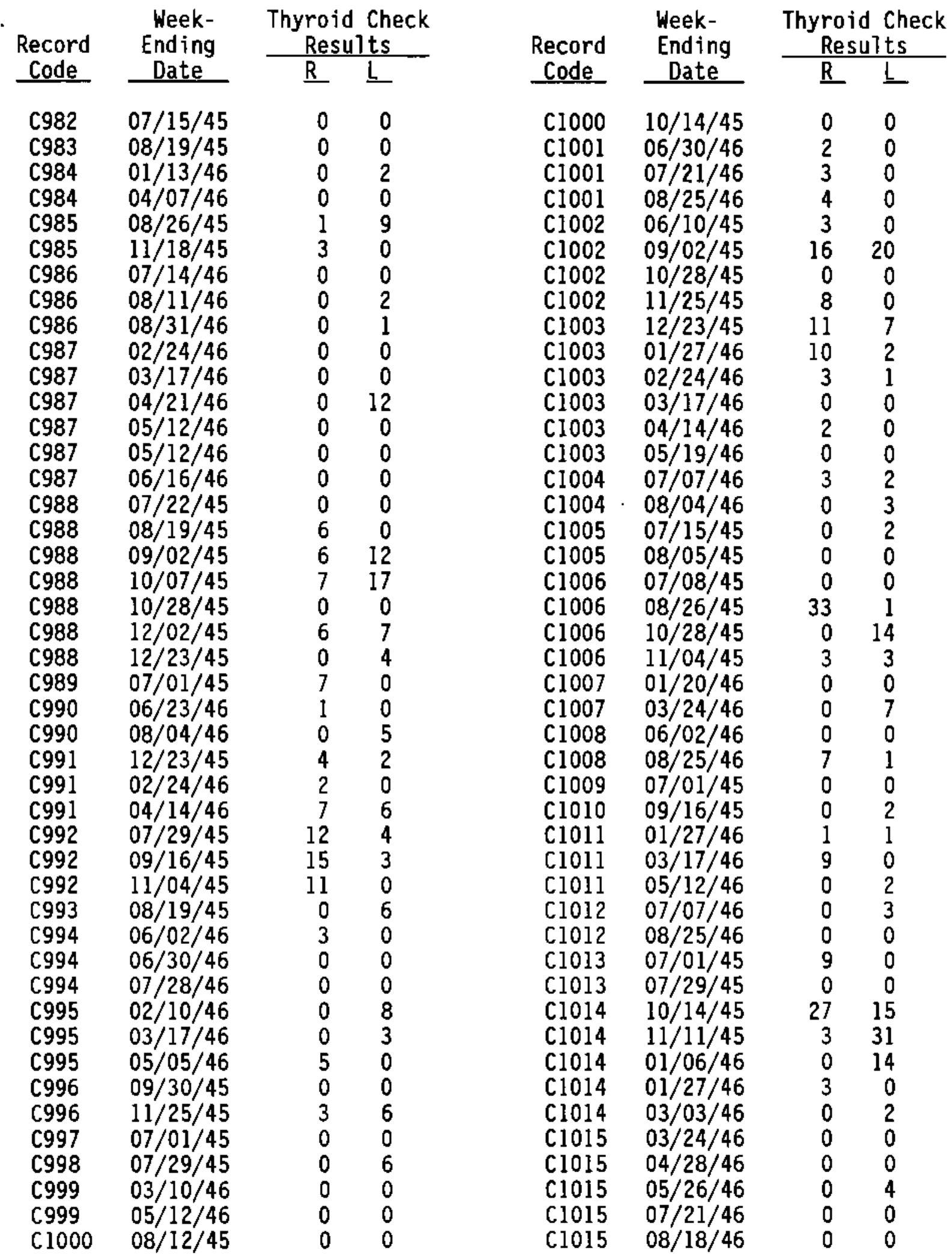


IABLE A.1. (contd)

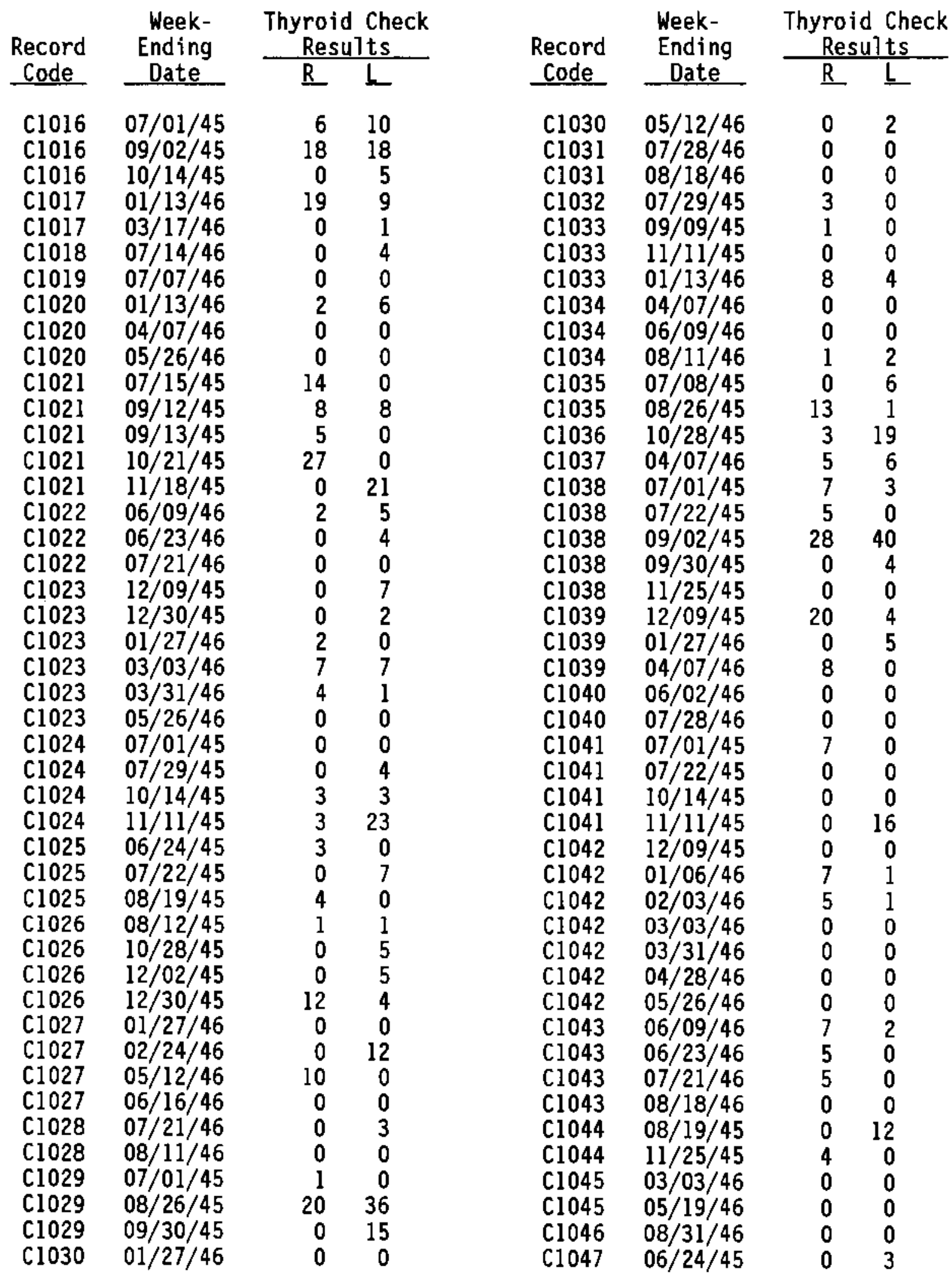


TABLE A.1. (contd)

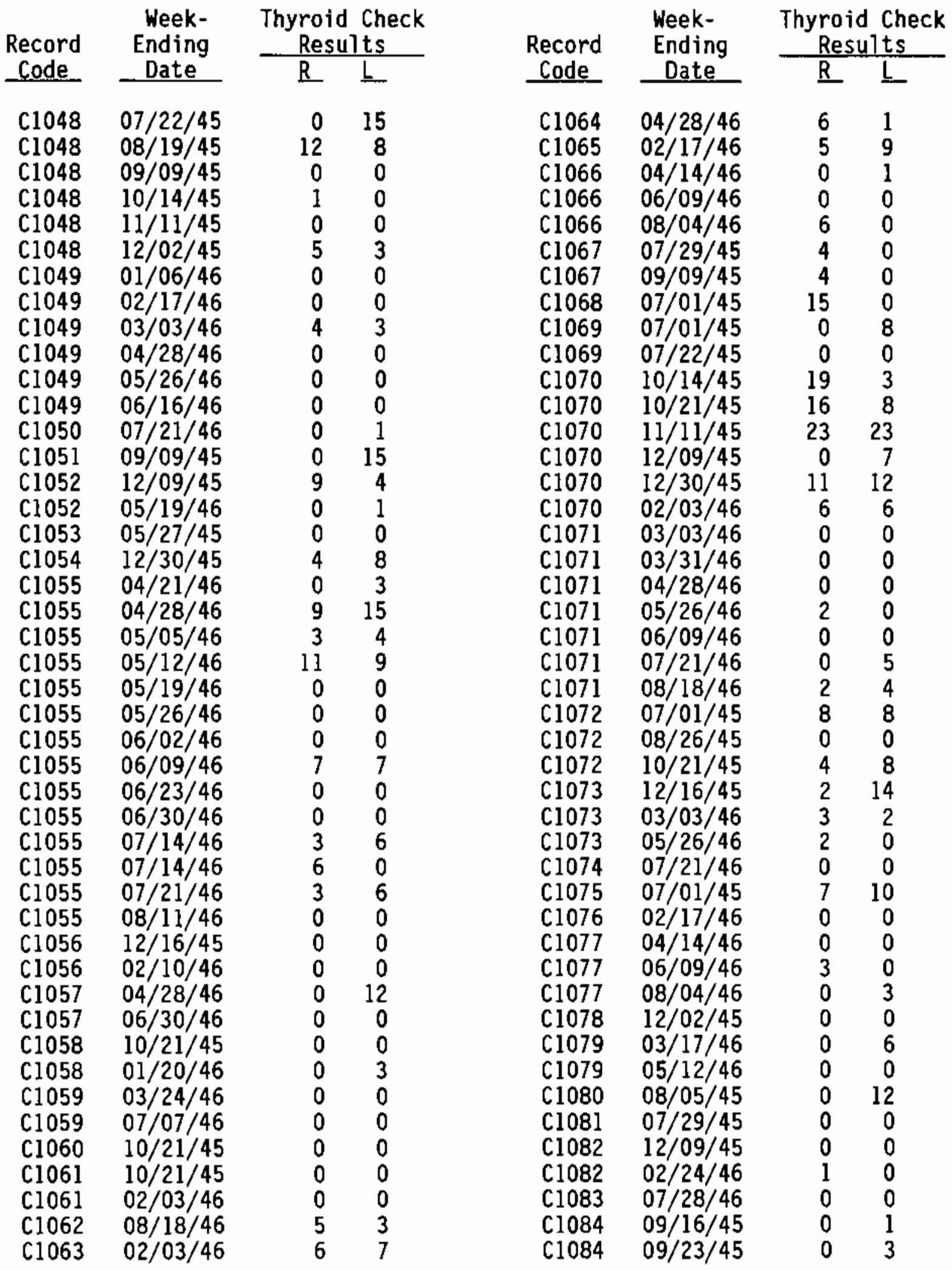


TABLE A.1. (contd)

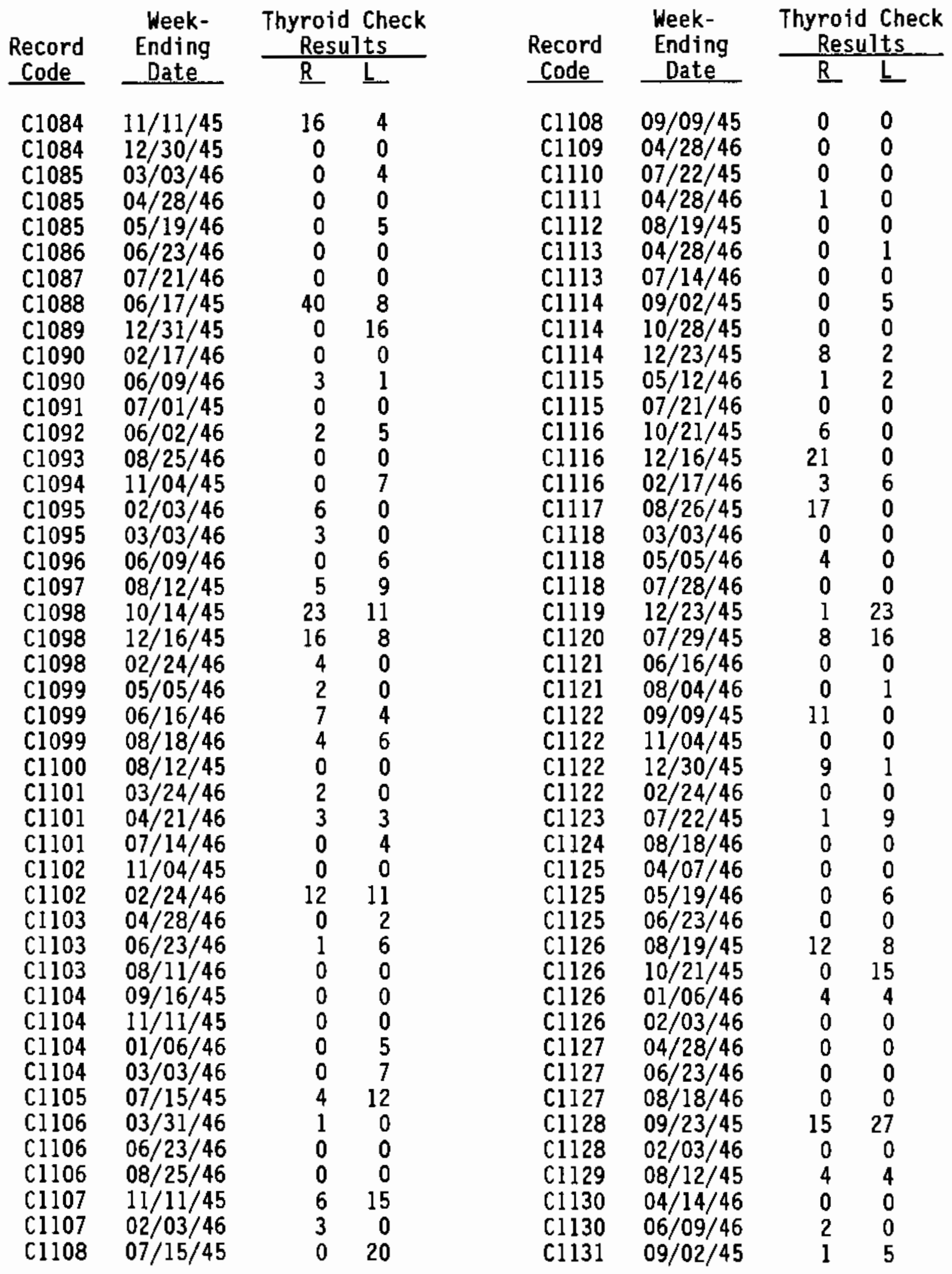


IABLE A.1. (contd)

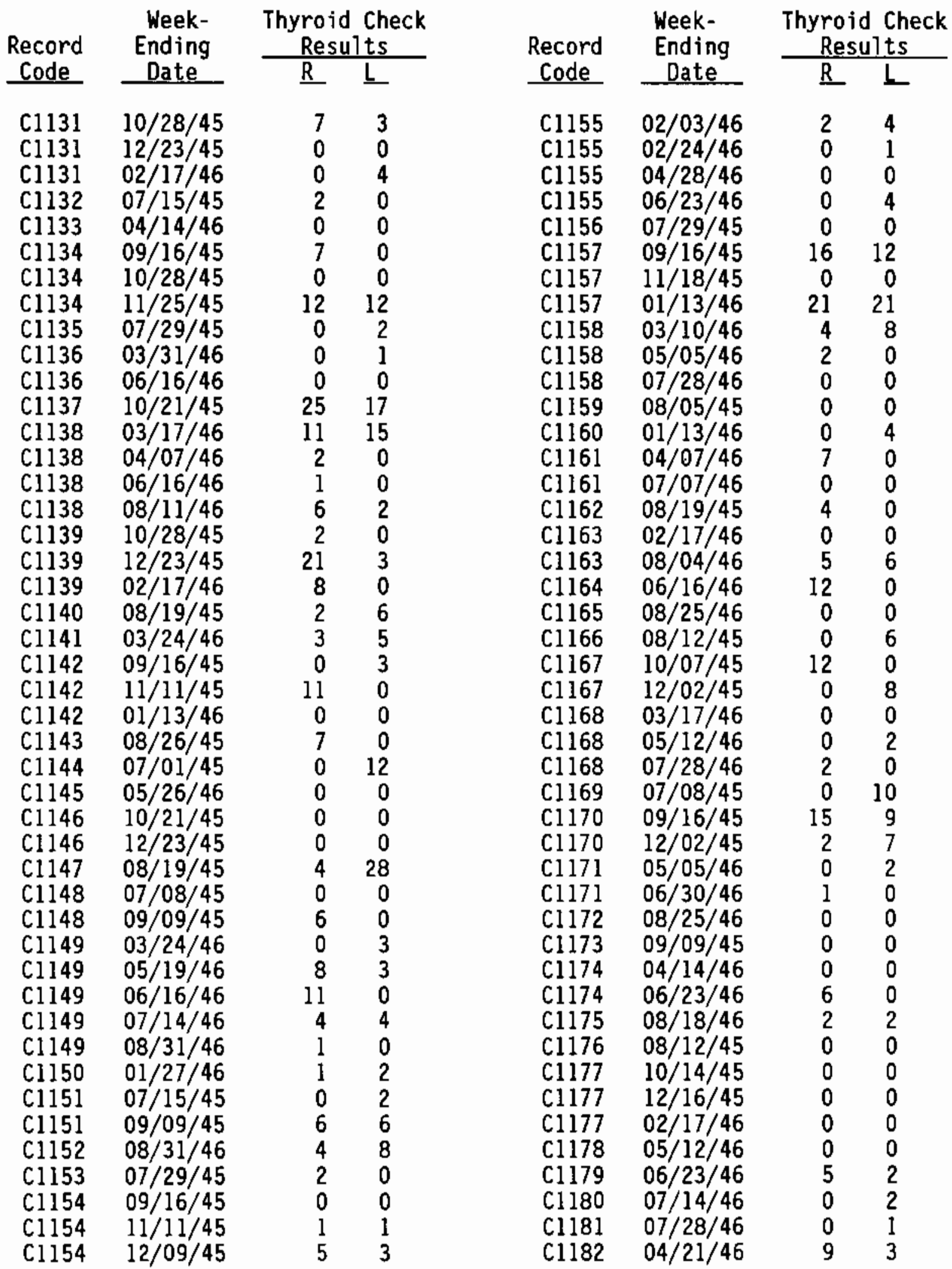


TABLE A.1. (contd)

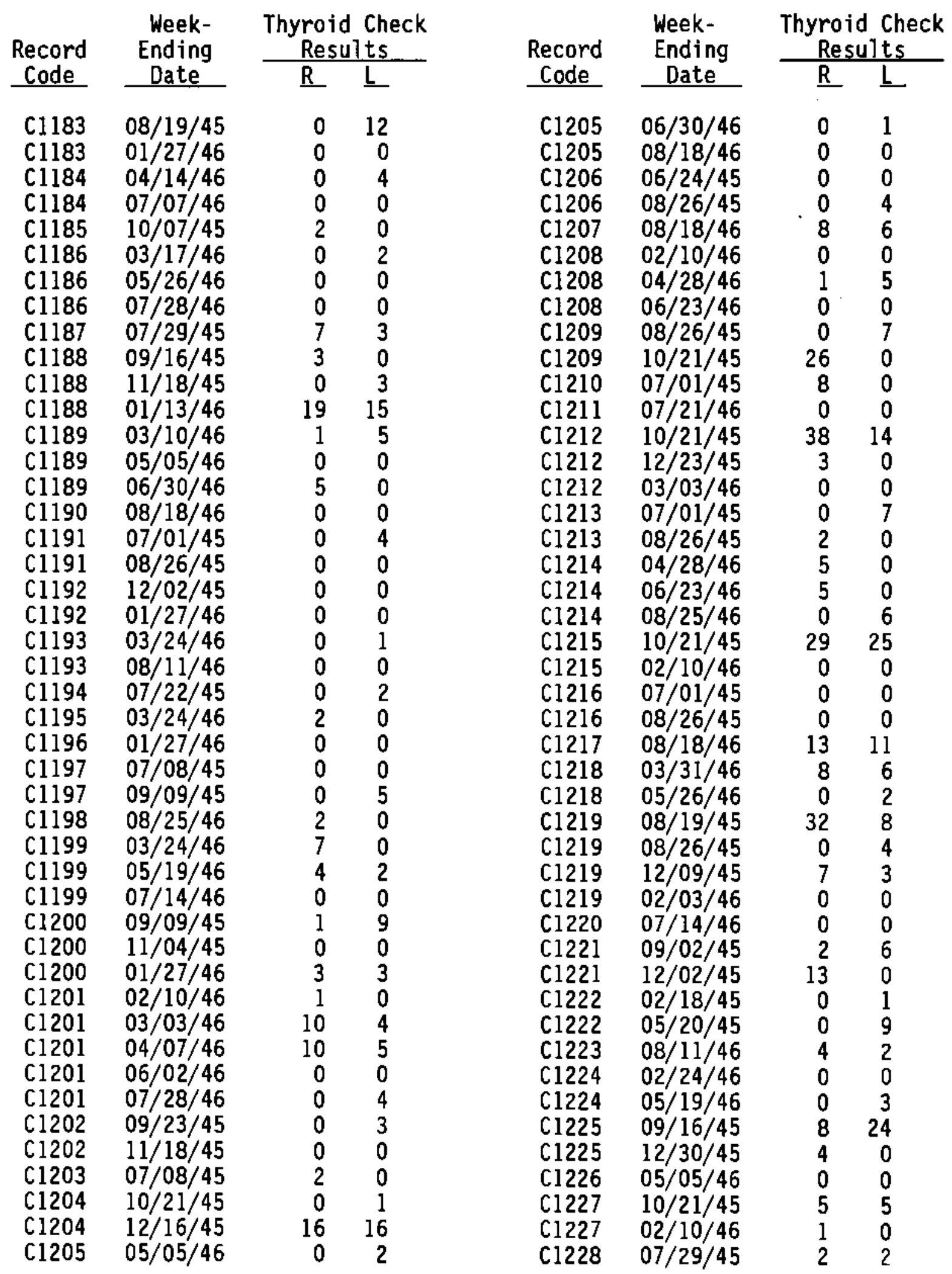


TABLE A.1. (contd)

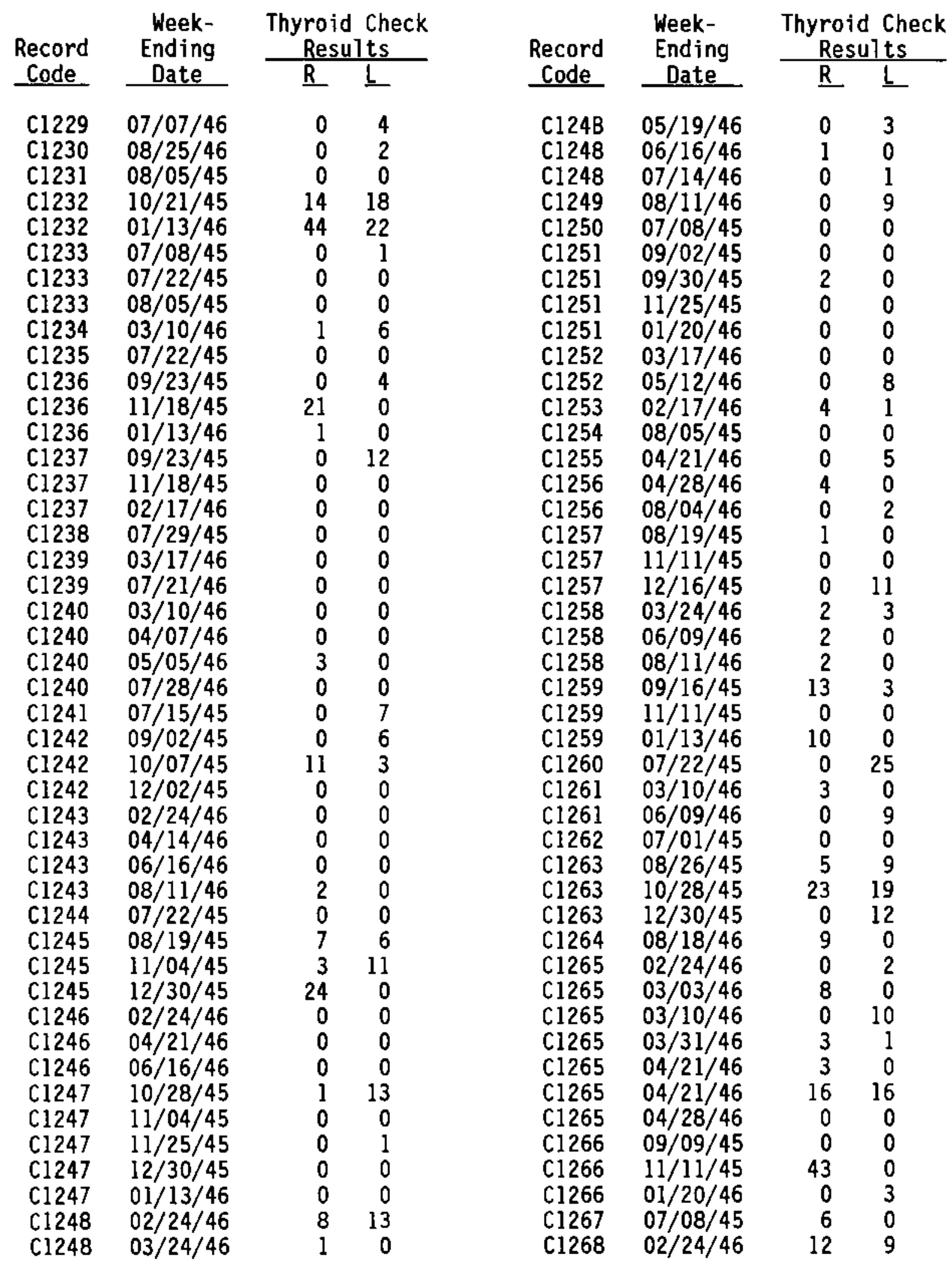


TABLE A.1. (contd)

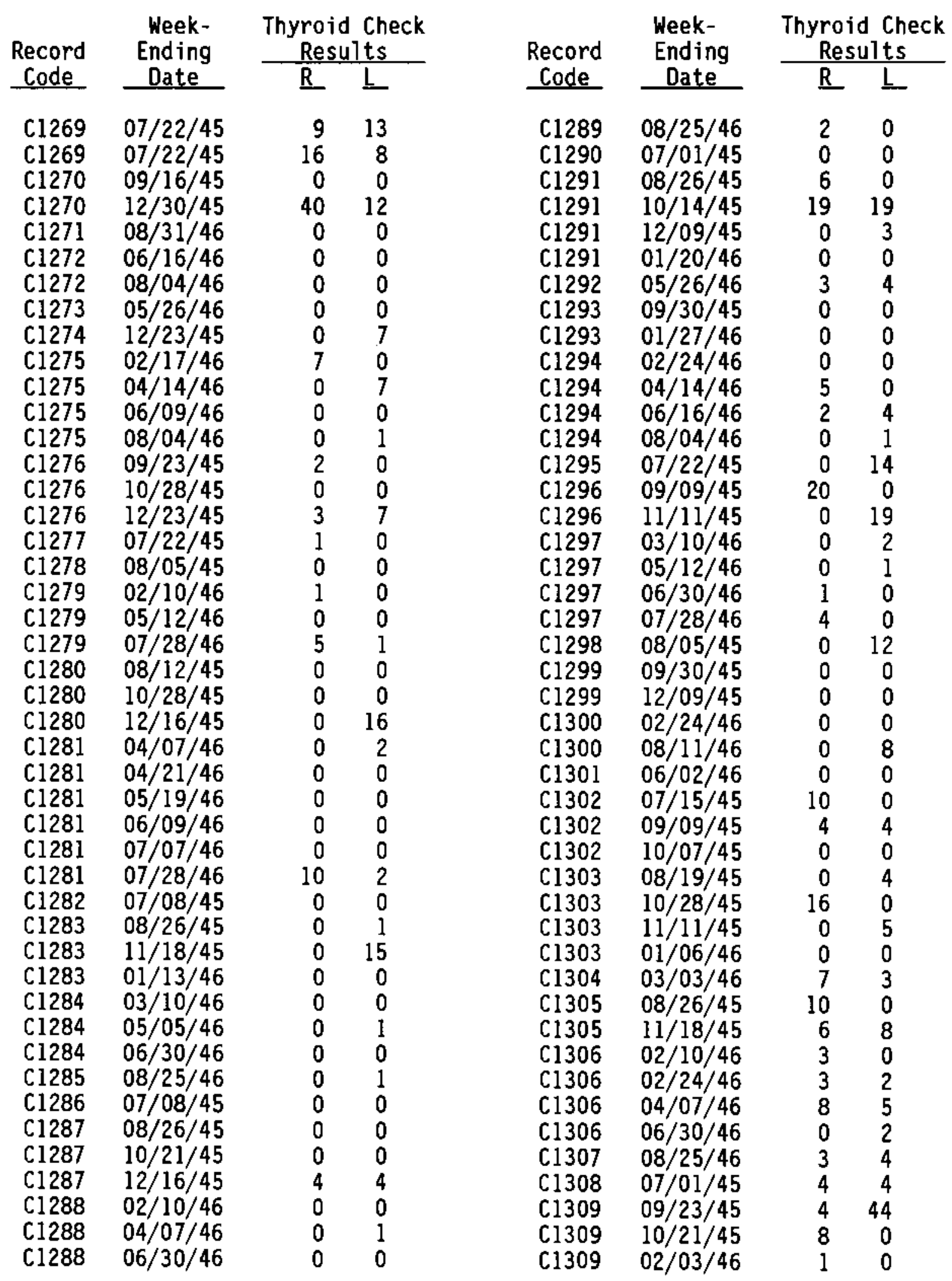


TABLE A.1. (contd)

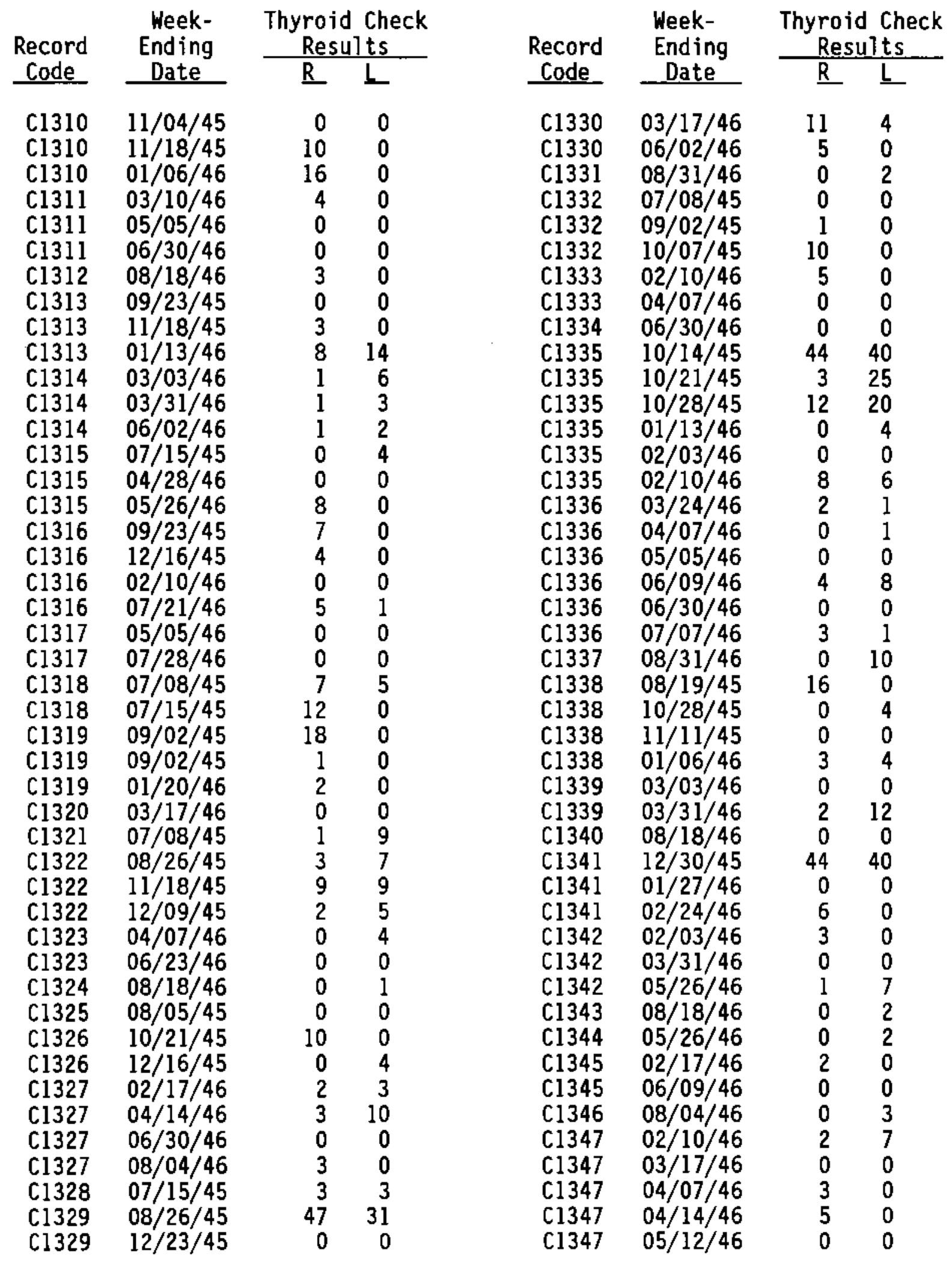


TABLE A.1. (contd)

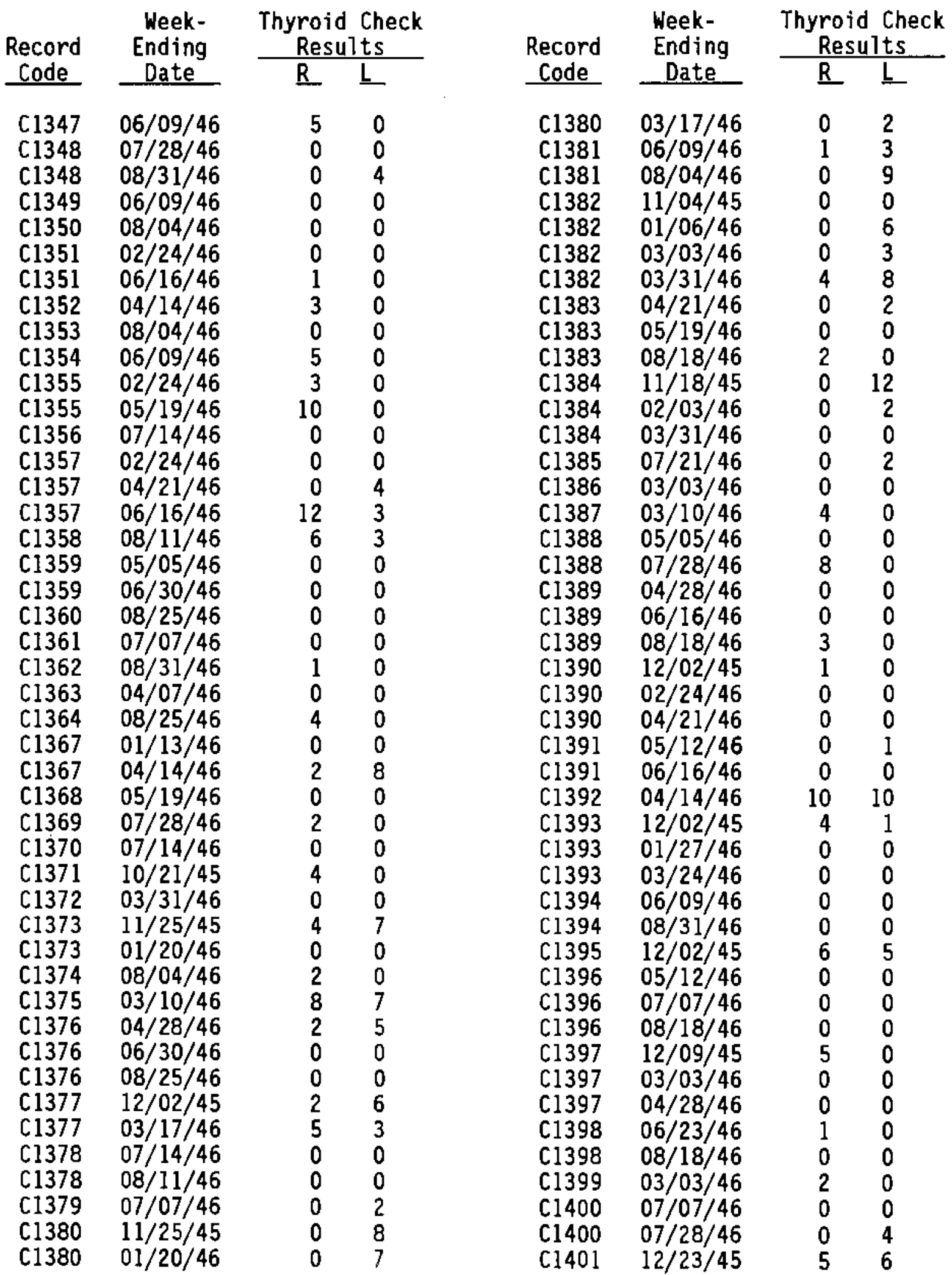


TABLE A.1. (contd)

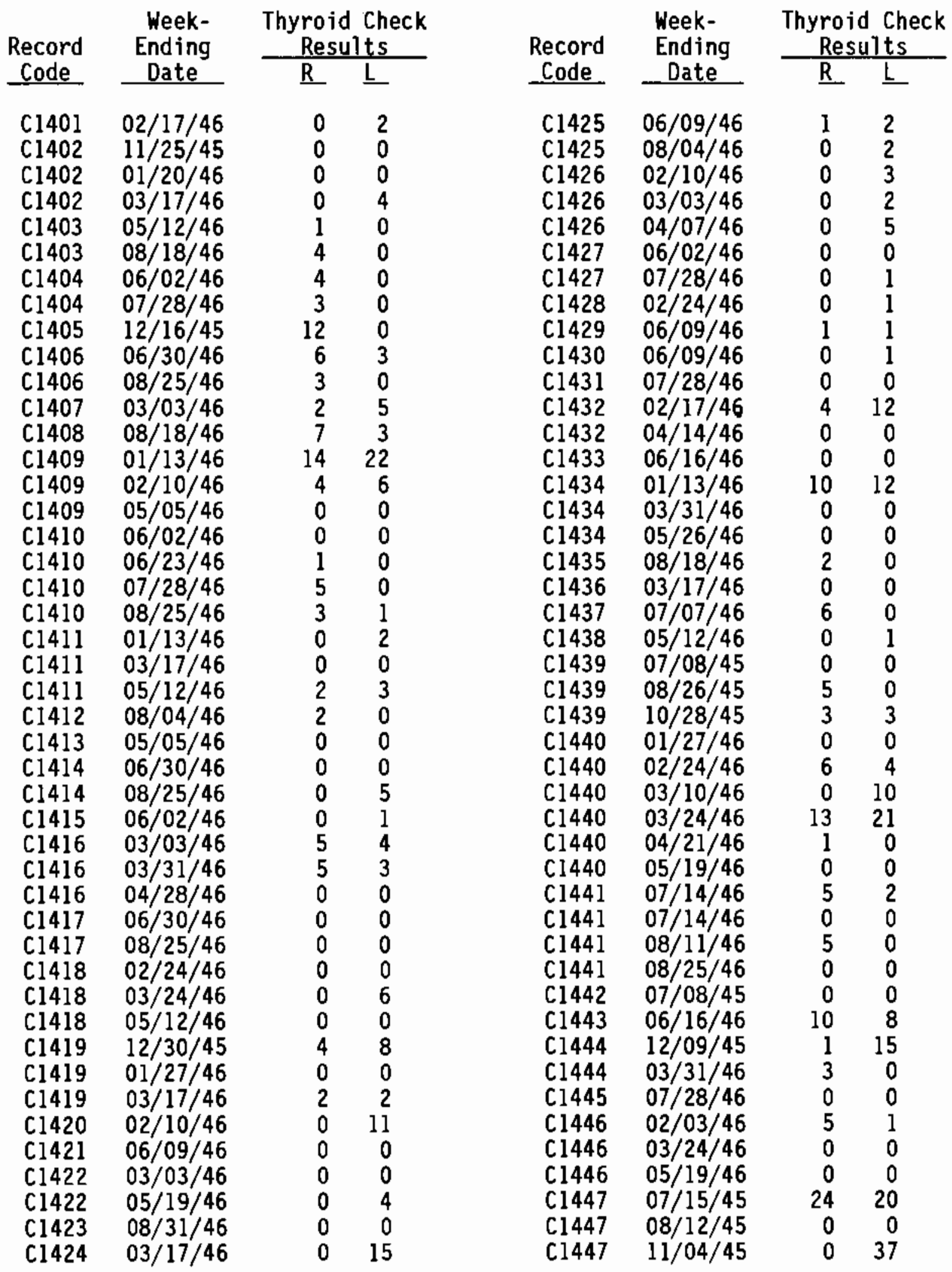


IABLE A.1. (contd)

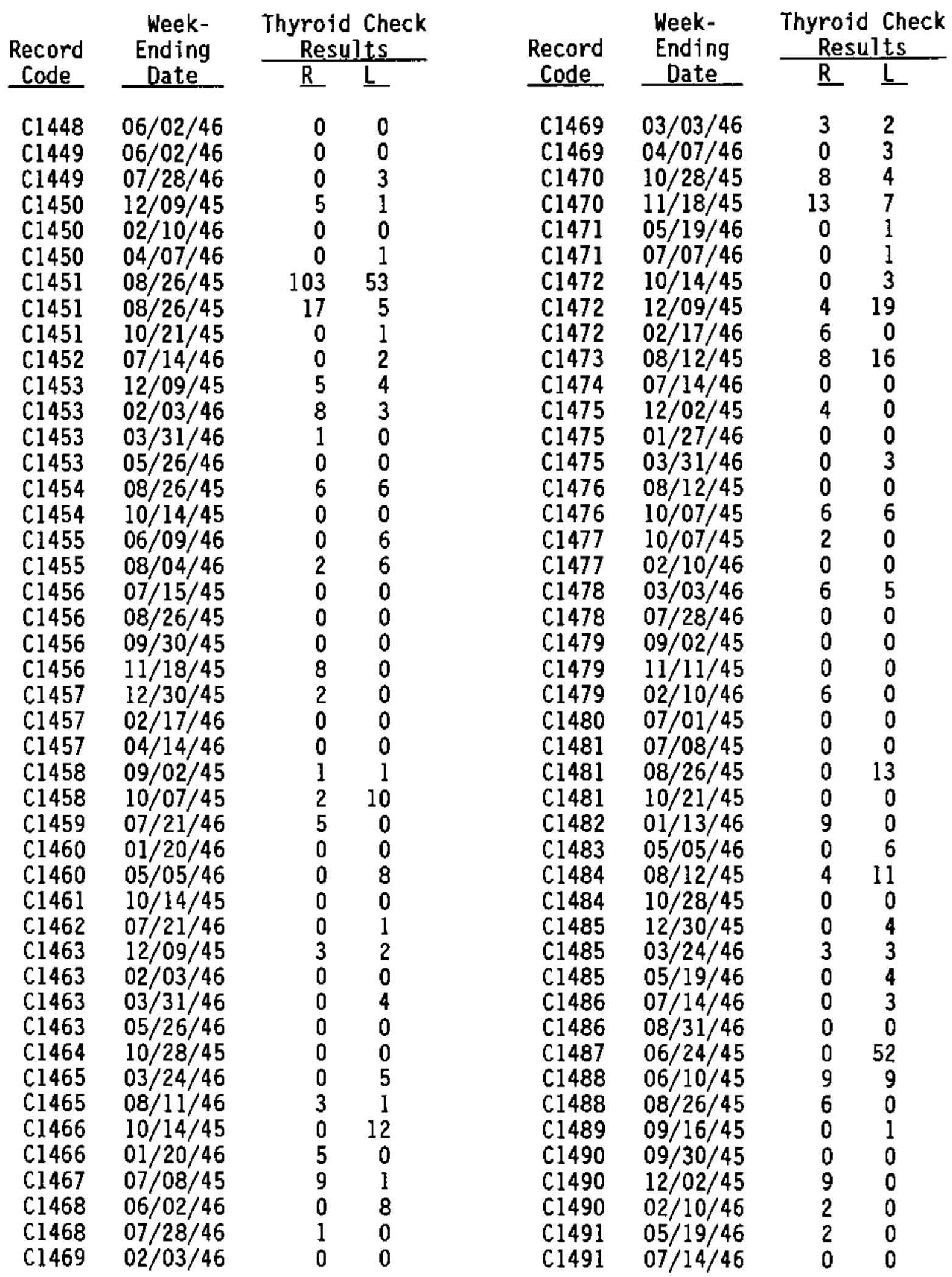


TABLE A.1. (contd)

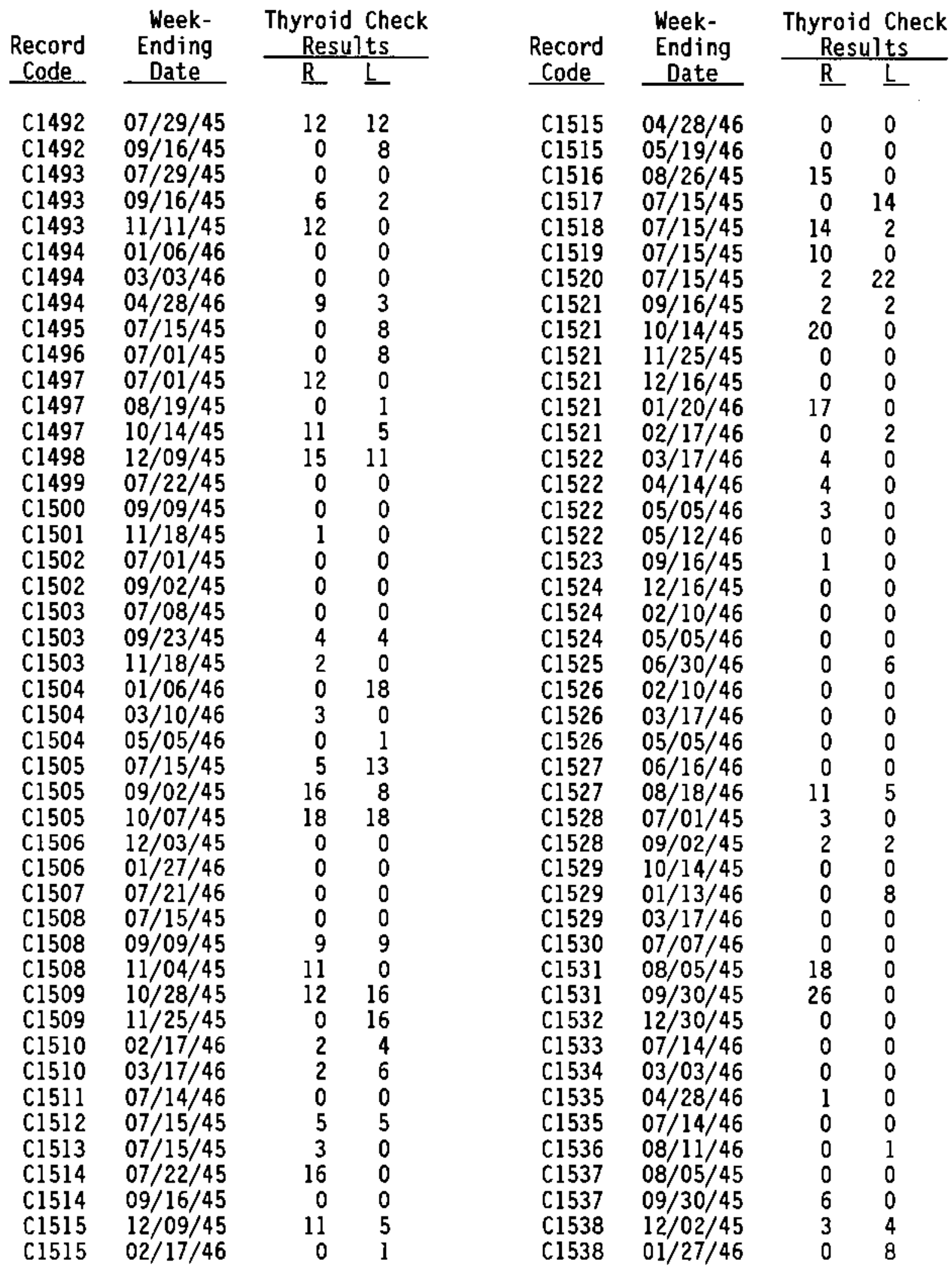


TABLE A.1. (contd)

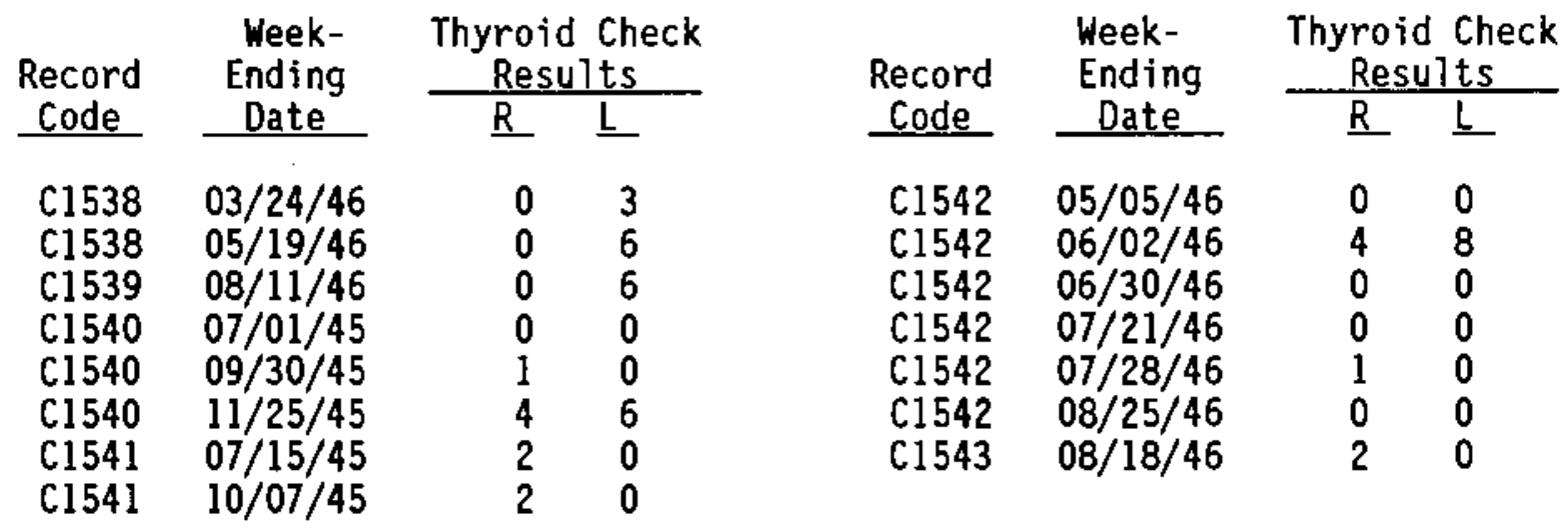




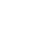


APPENDIX B

SUMMARY OF TSP COMMENTS AND BATTELLE RESPONSES 
SUMMARY OF TSP COMMENTS AND BATTELLE RESPONSES

Document Number PNL-7254 HEDR

Document Title Evaluation of Thyroid Radioactivity Measurement Data from Hanford Workers, 1944-1946

\begin{tabular}{|c|c|c|c|c|}
\hline $\begin{array}{l}\text { Comment } \\
\text { Number }\end{array}$ & Commenter & $\begin{array}{c}\text { Page, } \\
\text { Paragraph }\end{array}$ & Comment Summary & Resolution \\
\hline 1. & J. Stohr & Page 16 & $\begin{array}{l}\text { The assumption that a "short" counting time con- } \\
\text { stitutes } 1 \text { minute for each thyroid lobe may be } \\
\text { too large a step to take, given the evidence pre- } \\
\text { sented in its support. "Short" could mean any- } \\
\text { thing from } 5 \text { seconds to } 5 \text { minutes. }\end{array}$ & $\begin{array}{l}\text { NA - For the purposes of this } \\
\text { report, a l-minute counting time } \\
\text { was assumed because it was con- } \\
\text { sistent with anecdotal recol- } \\
\text { lections from the time period of } \\
\text { interest and with procedures } \\
\text { written during the early 1950s. } \\
\text { Anecdotal recollections state a } \\
\text { counting period in the general } \\
\text { range of } 1 \text { to } 5 \text { minutes. A count- } \\
\text { ing period much less than l minute } \\
\text { is unlikely because of the rela- } \\
\text { tively insensitive instrument and } \\
\text { the resulting unsatisfactory } \\
\text { counting statist ics. A longer } \\
\text { counting period is possible and } \\
\text { would serve to improve the count- } \\
\text { ing statistics and reduce the } \\
\text { overall measurement uncertainty. } \\
\text { However, from the range of most } \\
\text { likely counting times, a l-minute } \\
\text { counting time maximizes the count- } \\
\text { ing variability. The easily quan- } \\
\text { tifiable, random error of the } \\
\text { counting statistics is probably } \\
\text { relatively small compared with the } \\
\text { systematic errors of the counting } \\
\text { process. }\end{array}$ \\
\hline
\end{tabular}



Hanford Workers, 1944-1946

\begin{tabular}{|c|c|c|c|c|}
\hline $\begin{array}{l}\text { Comment } \\
\text { Number }\end{array}$ & Commenter & $\begin{array}{c}\text { Page, } \\
\text { Paragraph }\end{array}$ & Comment Summary & Resolution \\
\hline 2. & JS & & $\begin{array}{l}\text { The uncertainty that exists with the thyroid } \\
\text { count results leaves me thinking that it would be } \\
\text { difficult to use any of this report in the HEDR } \\
\text { Project. }\end{array}$ & $\begin{array}{l}\text { We should be able to use these } \\
\text { data in the future; however, } \\
\text { because of the large uncertainty } \\
\text { inherent in them it will be dif- } \\
\text { ficult to draw any quant itative } \\
\text { conclusions from them. Because of } \\
\text { the qualified assumptions that } \\
\text { must be made (all environmental } \\
\text { exposure, all adult males, all } \\
\text { Richland residents etc.), meas- } \\
\text { urements are probably itmited to } \\
\text { being used as qualitative indi- } \\
\text { cators, e.g. checking the shape } \\
\text { of the dose distributions or esti- } \\
\text { mating the upper bound on doses. } \\
\text { In summary, they are useable as a } \\
\text { reasonability check, but not for } \\
\text { definitive answers. }\end{array}$ \\
\hline 3. & A. Conklin & & $\begin{array}{l}\text { It appears impossible to differentiate between } \\
\text { occupational exposure and exposure received at } \\
\text { home. The uncertainties are extremely high. }\end{array}$ & $\begin{array}{l}\text { NA - Correct. Certain assumptions } \\
\text { would have to be made to further } \\
\text { analyze these data (e.g., all } \\
\text { iodine detected was due to envi- } \\
\text { ronmental exposure). Such anal- } \\
\text { ysis is beyond the scope of this } \\
\text { report. }\end{array}$ \\
\hline$N A=N_{0}$ & action. & & & \\
\hline
\end{tabular}


SUMMARY OF TSP COMMENTS AND BATTELLE RESPONSES

Document Number PNL-7254 HEDR
Document Title Evaluation of Thyroid Radioactivity Measurement Data from Hanford Workers, 1944-1946

\begin{tabular}{|c|c|c|c|c|}
\hline $\begin{array}{l}\text { Comment } \\
\text { Number }\end{array}$ & Commenter & $\begin{array}{c}\text { Page, } \\
\text { Paragraph }\end{array}$ & Comment Summary & Resolution \\
\hline 4. & B. Shleien & & $\begin{array}{l}\text { Did the workers, or some of them, wear respira- } \\
\text { tors at any time? }\end{array}$ & $\begin{array}{l}\text { NA - Some workers did wear respi- } \\
\text { rators in the facilities. The } \\
\text { respirators were apparently stan- } \\
\text { dard U.S. Army issue assault } \\
\text { masks, with cartridges designed } \\
\text { for particulate filtration. It is } \\
\text { unclear whether charcoal filters } \\
\text { for iodine filtration were avail- } \\
\text { able, as anecdotal recollectlons } \\
\text { from individuals employed in the } \\
\text { late 1940s differ on this point } \\
\text { and may be recalling even later } \\
\text { years. Anecdotes do agree, how- } \\
\text { ever, on the fact that ventilation } \\
\text { in the canyon buildings was very } \\
\text { good during the l940s, and there } \\
\text { was very ijtle airborne contam- } \\
\text { ination. The amount of time masks } \\
\text { were worn was also variable, } \\
\text { depending on the individual, the } \\
\text { type of work performed, and the } \\
\text { stage of the processing. Masks } \\
\text { were apparently never worn outside } \\
\text { the facilities. Without documen- } \\
\text { tation, it would be difficult to } \\
\text { quantify or even make generaliza- } \\
\text { tions about mask usage in the } \\
\text { facilities. }\end{array}$ \\
\hline
\end{tabular}



Hanford Horkers, 1944-1946

\begin{tabular}{|c|c|c|c|c|}
\hline $\begin{array}{l}\text { Comment } \\
\text { Number }\end{array}$ & Comnenter & $\begin{array}{c}\text { Page, } \\
\text { Paragraph }\end{array}$ & Comnent Summary & Resolution \\
\hline 5. & $\begin{array}{l}\text { M.A. } \\
\text { Robkin }\end{array}$ & Page 18 & $\begin{array}{l}1 \text { was somewhat taken aback by the assertion that } \\
\text { only an even number of counts could be registered } \\
\text { by a binary scaler. As I remember the binary } \\
\text { scaler, odd numbers were not only possible, they } \\
\text { were rout ine. }\end{array}$ & $\begin{array}{l}\text { This is correct. The binary scal- } \\
\text { ers used were capable of provid- } \\
\text { ing an indication of an odd number } \\
\text { of counts. The text has been mod- } \\
\text { ified to reflect the change. }\end{array}$ \\
\hline 6. & $\begin{array}{l}\text { Genevieve } \\
\text { S. } \\
\text { Roessler }\end{array}$ & & $\begin{array}{l}\text { The sparse number of measurements on any one } \\
\text { individual is the most serious problem because } \\
\text { you can't have any confidence that the measure- } \\
\text { ment coincided with a time of high intake. }\end{array}$ & $\begin{array}{l}\text { These data may very possibly have } \\
\text { not hit the periods of greatest } \\
\text { OCCUPATIONAL radiofodine exposure. } \\
\text { However, occupational exposure is } \\
\text { highly variable on the individual } \\
\text { level as well as beting beyond the } \\
\text { HEOR scope. Nevertheless, the } \\
\text { data were obtained during the per- } \\
\text { lod of largest environmental } \\
\text { releases, and so would be gener- } \\
\text { ally indicative of the greatest } \\
\text { potent ial for environmental expo- } \\
\text { sure to radioiodines. }\end{array}$ \\
\hline 7. & GSR & & $\begin{array}{l}\text { All of these measurements show that there was a } \\
\text { very real concern for radiation safety, espe- } \\
\text { cially with regard to iodine isotopes. }\end{array}$ & KA \\
\hline 8. & GSR & & $\begin{array}{l}\text { Is it really true that no instruments still exist } \\
\text { like the ones that were used to make the } \\
\text { measurements? }\end{array}$ & $\begin{array}{l}\text { NA - There is no indication that } \\
\text { such instruments still exist, nor } \\
\text { are they included in a historical } \\
\text { review of Hanford portable }\end{array}$ \\
\hline$N A=N o$ & action. & & & \\
\hline
\end{tabular}


SUMMARY OF TSP COMMENTS AND BATTELLE RESPONSES

Document Number PNL-7254 HEDR

Document Titie Evaluation of Thyroid Radioactivity Measurement Data from Hanford Workers, 1944-1946

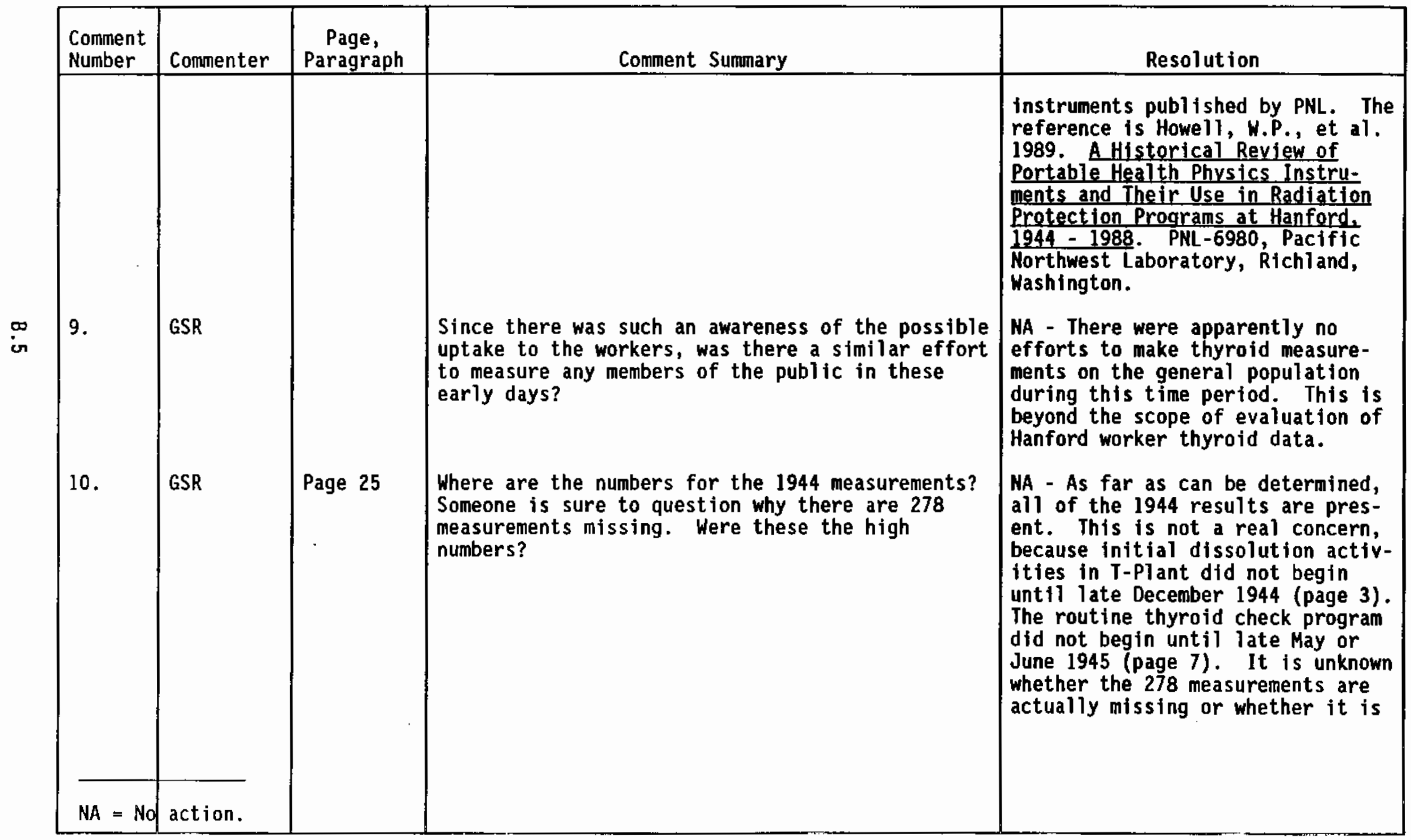


SUMMARY OF TSP COMMENTS AND BATTELLE RESPONSES

Document Number PNL-7254 HEDR

Document Title Evaluation of Thyroid Radioactivity Measurement Data from Hanford Workers, 1944-1946

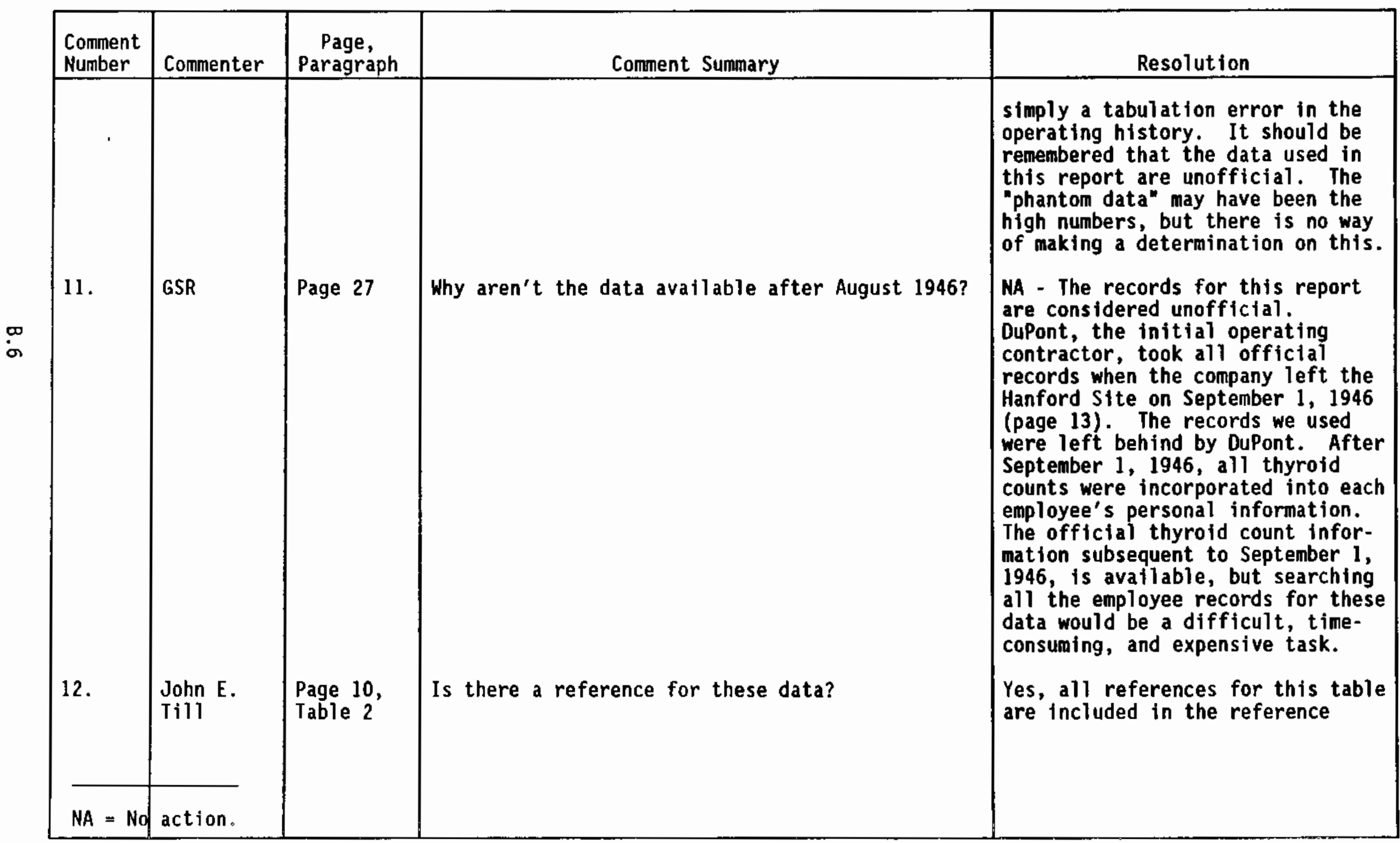


SUMMARY OF TSP COMMENTS AND BATTELLE RESPONSES

Document Number PNL-7254 HEDR

Document Title Evaluation of Thyroid Radioactivity Measurement Data from Hanford Workers, 1944-1946

\begin{tabular}{|c|c|c|c|c|}
\hline $\begin{array}{l}\text { Comment } \\
\text { Number }\end{array}$ & Commenter & $\begin{array}{l}\text { Page, } \\
\text { Paragraph }\end{array}$ & Comment Summary & Resolution \\
\hline & & & & $\begin{array}{l}\text { section. Table } 2 \text { has been refor- } \\
\text { matted to include the references. }\end{array}$ \\
\hline 13. & JET & Page 16 & A photograph of the old instrument would help. & $\begin{array}{l}\text { NA - No photographs of this } \\
\text { instrument are known to exist. }\end{array}$ \\
\hline 14. & JET & Page 19 & $\begin{array}{l}\text { Equation: The + sign should be raised. Also, } \\
\text { why are equations not numbered in the report? }\end{array}$ & $\begin{array}{l}\text { Agreed; correction was made. } \\
\text { Equations were not numbered } \\
\text { because there was no need to refer } \\
\text { to them by number in text. }\end{array}$ \\
\hline 15. & JET & $\begin{array}{l}\text { Page } 28, \\
\text { Table } 4\end{array}$ & $\begin{array}{l}\text { Why are we missing numbers (after } 40 \text { ), yet we } \\
\text { report } 38 \text { as 0? Perhaps a footnote is needed. } \\
\text { (Likewise Table 5.) }\end{array}$ & $\begin{array}{l}\text { Only } 11 \text { thyroid check results are } \\
\text { above } 38 \text { net CPM, out of nearly } \\
8,000 \text { results. To save space, } \\
\text { only those values at which a } \\
\text { result was recorded are included } \\
\text { in the table. The table entry for } \\
38 \text { net CPM has been removed from } \\
\text { the table, because there are no } \\
\text { results at this value. Footnotes } \\
\text { were added to Tables } 4 \text { and } 5 \text {. }\end{array}$ \\
\hline 16. & JET & $\begin{array}{l}\text { Page } 32, \\
\text { para. } 2, \\
\text { line } 3\end{array}$ & $" \ldots$ these data.. & Text was changed. \\
\hline 17 . & A. & & $\begin{array}{l}\text { How would this relate to the other years that may } \\
\text { have had greater exposures? }\end{array}$ & $\begin{array}{l}\text { NA - Comparison to radioiodine } \\
\text { exposures in other years would }\end{array}$ \\
\hline$N A=N_{0}$ & action. & & & \\
\hline
\end{tabular}


SUMMARY OF TSP COMMENTS AND BATTELLE RESPONSES

Document Number PNL-7254 HEDR
Document Title Evaluation of Thyroid Radioactivity Measurement Data from Hanford Workers, 1944-1946

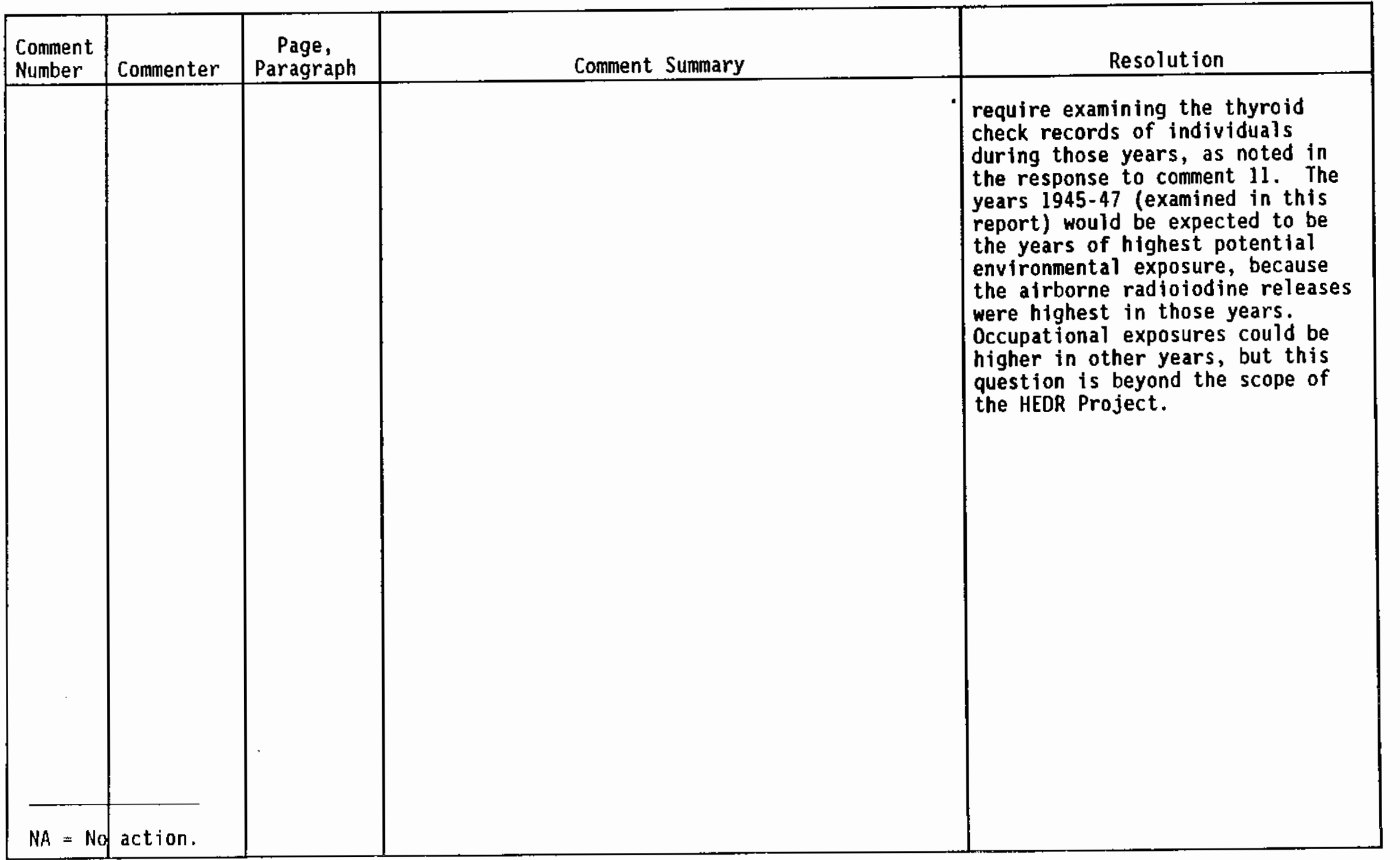




\section{DISTRIBUTION}

No. of

Copies

\section{OFFSITE}

18 Technical Steering Panel

D. S. Barth

University of Nevada

4505 Maryland Parkway

Las Vegas, NV 89154

W. A. Bishop

2503 Wedgewood Court SE

01 ympia, WA 98501

M. L. Blazek

Oregon Department of Energy

625 Marion Street N.E.

Salem, OR 97303

G. G. Caldwell

Director

Tulsa City-County Health Dept

4616 East 15th Street

Tulsa, OK 74112

S. N. Davis

Dept. of Hydrology \& Water Resources

Bldg. 11

University of Arizona

Tucson, AZ 85721

N. J. Germond

224 Iron Mountain Blvd.

Lake Oswego, OR 97034

P. C. Klingeman

Civil Engineering Dept.

Oregon State University

Corvallis, OR 97331-2302

K. J. Kopecky

Fred Hutchinson Cancer

Research Center

1124 Columbia Street

Seattle, WA 98104
No. of

Copies

R. L. Morril]

Dept. of Geography

DP-10

University of Washington

Seattle, WA 98195

A. H. Murphy

c/o CTimate Analyses Center

National Weather Service, NOAA

W/NMC51, WWB, Room 604

Washington, DC 20233

V. Nguyen

EWA, Inc.

133 lst Ave. N.

Minneapolis, MN 55401

D. W. Price

Agricultural Economics

Hulbert Hall Room 211

Washington State University

Puliman, WA 99164-6210

M. A. Robkin

Radiological Sciences SB-75

University of Washington

Seattle, WA 98195

G. S. Roessler

Rt. 1, Box 139H

Elysian, MN 56028

B. Shleien

2421 Homestead Drive

Silver Springs, MD 20902

A. P. Slickpoo, Sr.

P. 0. Box 331

$809 \mathrm{Nez}$ Perce Lane

Kamiah, ID 83536

J. E. Till

Rt. 2 Box 122

Neeses, SC 29107 
No, of

Copjes

D. E. Walker, Jr.

P.0. Box 4147

Boulder, CO 80306

2 DOE Office of Scientific and Technical Information

Technical Information Center P.0. Box 62

Oak Ridge, TN 37830

18 K. Charlee

Office of Nuclear Waste Mgmt.

Department of Ecology

99 South Sound Center

Mai1 Stop PV-11

Olympia, WA 98504

H. A. Haerer

NUS Corporation

430 Broadmoor

Richland, WA 99352

J. Thomas, HEAL

325 S. Oak St.

Spokane, WA 99204
No. of

Copjes

ONSITE

2 DOE Richland Operations

R. F. Brich, SED

A5-55

M. W. Tiernan, SED

A5 -55

34 Pacific Northwest Laboratory

J. M. Daer (10) K6-89

W. A. Glass (6)

S. P. Gydesen

$\mathrm{K} 4-13$

T. A. Ikenberry (5) K3-54

A. H. McMak in

B. A. Napier

K6-86

W. L. Templeton

K3-54

Public Reading Room (5) Al-65

Publishing Coordination $\mathrm{Kl}-11$

Records Center

$\mathrm{K} 3-70$

Technical Library (2) P8-55 